Nevada

Environmental Management

Operations Activity

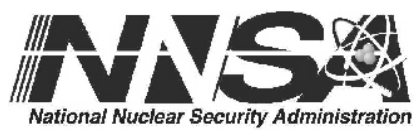

Post-Closure Report for Closed

Resource Conservation and

Recovery Act Corrective Action

Units, Nevada National Security

Site, Nevada

For Fiscal Year 2013

(October 2012-September 2013)

Controlled Copy No::

Revision: 0

January 2014 


\section{DISCLAIMER}

Reference herein to any specific commercial product, process, or service by trade name, trademark, manufacturer, or otherwise, does not necessarily constitute or imply its endorsement, recommendation, or favoring by the U.S. Government or any agency thereof.

This report has been reproduced directly from the best available copy.

Available for sale to the public from:

U.S. Department of Commerce

National Technical Information Service

5301 Shawnee Road

Alexandria, VA 22312

Telephone: (800) 553-6847

Fax: (703) 605-6900

E-mail: orders@ntis.gov

Online ordering: http://www.ntis.gov/help/ordermethods.aspx

Available electronically at http://www.osti.gov/bridge.

Available for a processing fee to the U.S. Department of Energy and its contractors, in paper, from:

U.S. Department of Energy

Office of Scientific and Technical Information

P.O. Box 62

Oak Ridge, TN 37831-0062

Telephone: (865) 576-8401

Fax: (865) 576-5728

E-mail: reports@adonis.osti.gov 


\title{
POST-CLOSURE REPORT FOR CLOSED RESOURCE CONSERVATION AND RECOVERY ACT CORRECTIVE ACTION UNITS, NEVADA NATIONAL SECURITY SITE, NEVADA \\ FOR FISCAL YEAR 2013 \\ (OCTOBER 2012-SEPTEMBER 2013)
}

\author{
U.S. Department of Energy, \\ National Nuclear Security Administration \\ Nevada Field Office \\ Las Vegas, Nevada
}

Controlled Copy No.

Revision: 0

January 2014 
THIS PAGE INTENTIONALLY LEFT BLANK 


\section{POST-CLOSURE REPORT FOR CLOSED RESOURCE CONSERVATION AND RECOVERY ACT CORRECTIVE ACTION UNITS, NEVADA NATIONAL SECURITY SITE, NEVADA}

FOR FISCAL YEAR 2013 (OCTOBER 2012-SEPTEMBER 2013)

\footnotetext{
Approved By: /s/: Tiffany A. Lantow Tiffary. A. Lantow Industrial Sites Activity Lead
}

Date: $1 / 14 / 2014$

\section{- Date: $1 / 14 / 14$}

Robert F. Boehlecke

Environmental Management Operations Activity Manager 
THIS PAGE INTENTIONALLY LEFT BLANK 


\section{TABLE OF CONTENTS}

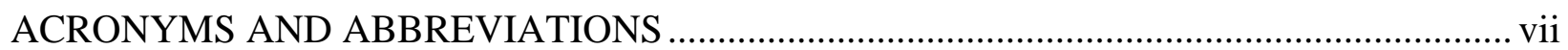

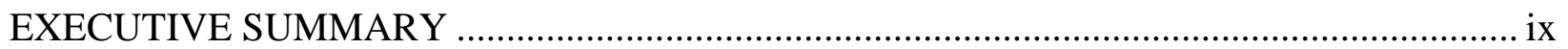

1.0 INSPECTIONS, REPAIRS, AND MAINTENANCE....................................................... 1

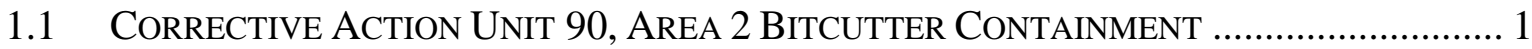

1.1.1 Post-Closure Requirements .......................................................................... 1

1.1.2 Inspections, Repairs, and Maintenance …………….................................. 1

1.2 Corrective Action Unit 91, AReA 3 U-3Fi InJection WeLl..................................... 1

1.2.1 Post-Closure Requirements ................................................................... 1

1.2.2 Inspections, Repairs, and Maintenance ………….......................................... 1

1.3 CoRrective Action Unit 92, AREa 6 DeCon Pond FACILITY .................................... 1

1.3.1 Post-Closure Requirements ......................................................................... 1

1.3.2 Inspections, Repairs, and Maintenance …………………………………..... 2

1.4 Corrective Action Unit 110, AREA 3 WMD U-3AX/Bl Crater .............................. 2

1.4.1 Post-Closure Requirements ......................................................................... 2

1.4.2 Inspections, Repairs, and Maintenance ……………………………………... 2

1.5 Corrective Action Unit 111, Area 5 WMD Retired MiXed Waste Pits ............. 3

1.5.1 Post-Closure Requirements ...................................................................... 3

1.5.2 Inspections, Repairs, and Maintenance …………………………………....... 3

1.6 Corrective Action Unit 112, Area 23 Hazardous Waste Trenches .................. 4

1.6.1 Post-Closure Requirements .............................................................................. 4

1.6.2 Inspections, Repairs, and Maintenance …………………………………….... 4

2.0 SUBSIDENCE SURVEYS AND VEGETATION SURVEYS ……………...................... 5

2.1 Corrective Action Unit 110, Area 3 WMD U-3aX/Bl Crater ............................... 5

2.1.1 Subsidence Survey ........................................................................................ 5

2.1.2 Vegetation Survey ……………………………………………………. 5

2.2 Corrective Action Unit 111, Area 5 WMD Retired Mixed Waste Pits ............. 5

2.2.1 Subsidence Survey................................................................................... 5

2.2.2 Vegetation Survey ....................................................................................... 8

3.0 CORRECTIVE ACTION UNIT 110 SOIL MOISTURE MONITORING.......................... 11

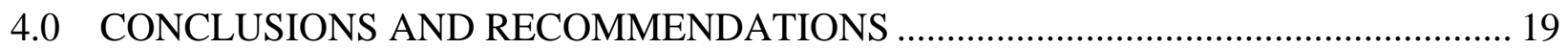

4.1 CoRrective Action Unit 90, AREA 2 Bitcutter ContainMENT............................. 19

4.2 CoRrective Action Unit 91, AREA 3 U-3Fi InJECTION WeLL................................... 19

4.3 CoRrective Action Unit 92, AREa 6 Decon Pond Facility …………………...... 19

4.4 Corrective Action Unit 110, AREA 3 WMD U-3AX/Bl Crater ............................ 19

4.5 Corrective Action Unit 111, Area 5 WMD Retired MiXed Waste Pits ........... 19

4.6 Corrective Action Unit 112, AREa 23 Hazardous Waste Trenches ................ 20

LIBRARY DISTRIBUTION LIST 


\section{LIST OF FIGURES}

Figure ES- 1. LOCATIONS OF Closed RESOURCE CONSERVATION AND RECOVERY ACT CORRECTIVE

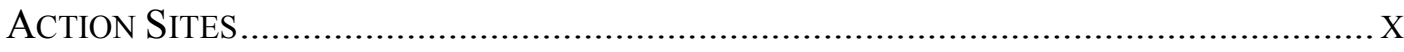

Figure 1. CORREctive Action Unit 110 Time Domain ReFlectometry LOCATIONS ............. 12

Figure 2. Precipitation Data for Meteorological Station Buster Jangle Y ................. 13

Figure 3. East TDR Nest A Soil Moisture Content Profile............................................. 14

Figure 4. EASt TDR Nest B Soil Moisture ConTENT Profile............................................ 15

Figure 5. West TDR Nest A Soil Moisture Content Profile........................................... 16

Figure 6. West TDR Nest B Soil Moisture Content Profile............................................... 17

\section{LIST OF TABLES}

Table 1. Corrective Action Unit 110 Subsidence Survey ReSults .................................. 6

TABle 2. Corrective ACtion Unit 111 SubSIDENCE SURVEY RESUlts ................................... 7

\section{APPENDICES}

APPENDIX A. INSPECTION CHECKLISTS

APPENDIX B. PhOTOGRAPHS 
Date: January 2014

\section{ACRONYMS AND ABBREVIATIONS}

$\begin{array}{ll}\text { CAU } & \text { Corrective Action Unit } \\ \mathrm{ft} & \text { foot (feet) } \\ \text { in. } & \text { inch(es) } \\ \text { NDEP } & \text { Nevada Division of Environmental Protection } \\ \text { SM } & \text { subsidence marker } \\ \text { TDR } & \text { Time Domain Reflectometry }\end{array}$


RCRA Post-Closure Report

Revision: 0

Date: January 2014

THIS PAGE INTENTIONALLY LEFT BLANK 
This report serves as the combined annual report for post-closure activities for the following closed Corrective Action Units (CAUs):

- CAU 90, Area 2 Bitcutter Containment

- CAU 91, Area 3 U-3fi Injection Well

- CAU 92, Area 6 Decon Pond Facility

- CAU 110, Area 3 WMD U-3ax/bl Crater

- CAU 111, Area 5 WMD Retired Mixed Waste Pits

- CAU 112, Area 23 Hazardous Waste Trenches

The locations of the sites are shown in Figure 1. This report covers fiscal year 2013 (October 2012-September 2013). The post-closure requirements for these sites are described in Resource Conservation and Recovery Act Permit Number NEV HW0101 and summarized in each CAU-specific section in Section 1.0 of this report. The results of the inspections, a summary of maintenance activities, and an evaluation of monitoring data are presented in this report.

Site inspections are conducted semiannually at CAUs 90 and 91 and quarterly at CAUs 92, 110, 111, and 112. Additional inspections are conducted at CAU 92 if precipitation occurs in excess of 0.50 inches in a 24-hour period and at CAU 111 if precipitation occurs in excess of 1.0 inch in a 24-hour period. Inspections include an evaluation of the condition of the units, including covers, fence, signs, gates, and locks.

In addition to visual inspections, soil moisture monitoring, vegetation evaluations, and subsidence surveys are conducted at CAU 110. At CAU 111, soil moisture monitoring, vegetation evaluations, subsidence surveys, direct radiation monitoring, air monitoring, radon flux monitoring, and groundwater monitoring are conducted.

The results of the vegetations surveys and an analysis of the soil moisture monitoring data at CAU 110 are presented in this report. Results of additional monitoring at CAU 111 are documented annually in the Nevada National Security Site Waste Management Monitoring Report Area 3 and Area 5 Radioactive Waste Management Sites and in the Nevada National Security Site Data Report: Groundwater Monitoring Program Area 5 Radioactive Waste Management Site, which will be prepared in approximately June 2014.

All required inspections, maintenance, and monitoring were conducted in accordance with the post-closure requirements of the permit. It is recommended to continue inspections and monitoring as scheduled. 


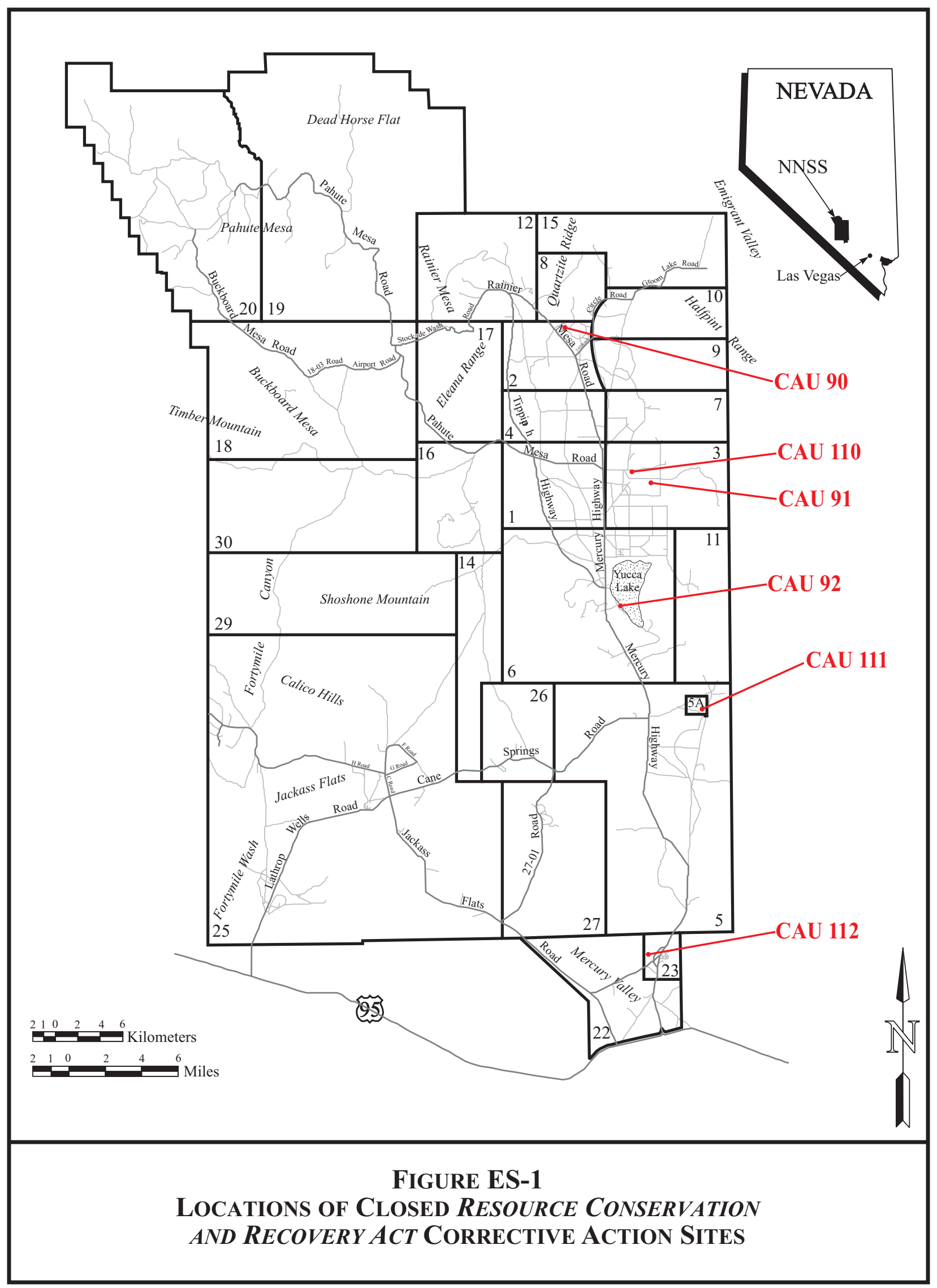




\subsection{INSPECTIONS, REPAIRS, AND MAINTENANCE}

\subsection{Corrective ACtion Unit 90, Area 2 Bitcutter Containment}

\subsubsection{Post-Closure Requirements}

Semiannual inspections are required to evaluate the condition of the unit. Photographs are taken, and the results of the inspections are documented on a checklist. Deficiencies other than general housekeeping issues are reported to the Nevada Division of Environmental Protection (NDEP) and remedied within 60 days of discovery.

\subsubsection{Inspections, Repairs, and Maintenance}

The first semiannual inspection was performed on December 11, 2012. The signs and fence were in good condition, and no settling or cracking was observed. Minor small animal burrows were noted, and sparse vegetation was present. It was recommended to evaluate the burrows and vegetation during the next inspection. No maintenance or repairs were required.

The second semiannual inspection was performed on June 12, 2013. The signs and fence were in good condition, and no settling or cracking was observed. There was no change in the animal burrows or vegetation from the December inspection. No maintenance or repairs were required.

\subsection{Corrective ACTION Unit 91, ARea 3 U-3Fi InJection Well}

\subsubsection{Post-Closure Requirements}

Semiannual inspections are required to evaluate the condition of the unit. Photographs are taken, and the results of the inspections are documented on a checklist. The permit does not specify a time limit for repairs at Corrective Action Unit (CAU) 91.

\subsubsection{Inspections, Repairs, and Maintenance}

Vegetation observed in September 2012 was removed on October 4, 2012. The first semiannual inspection was performed on March 12, 2013. The fence was in good condition, and no settling, vegetation, or animal burrows were observed. The red "WARNING" text on one of the signs was faded, and a new "WARNING" sticker was placed on the sign during the inspection. No additional maintenance or repairs were required.

The second semiannual inspection was performed on September 17, 2013. The fence was in good condition, and no settling or animal burrows were observed. Vegetation was present on the cover, and the red "WARNING" text on one of the signs was faded. A new "WARNING" sticker was placed on the sign during the inspection. Vegetation removal was completed within 60 days and will be reported in the next annual report.

\subsection{Corrective Action Unit 92, Area 6 Decon Pond Facility}

\subsubsection{Post-Closure Requirements}

Inspections are required quarterly and when precipitation occurs in excess of 0.50 inches (in.) in a 24-hour period. Photographs are taken, and the results of the inspection are documented on a checklist. The checklist documents the reason for the inspection (i.e., quarterly or excess precipitation) and any changes in the condition of the cover or fenced area, including, but not 
limited to, trash or debris within the fenced area, erosion of the cover, vegetation growing on the cover, and animal burrows or nesting activity. The condition of the fence, warning signs, gate, and lock is documented. Small cracks or settling imperfections (less than 2 in. deep) are documented, and repairs are scheduled on an annual basis. Larger disruptions are immediately reported to NDEP and remedied within 60 days of discovery.

\subsubsection{Inspections, Repairs, and Maintenance}

Vegetation observed in September 2012 was removed on October 4, 2012. On October 11, 2012, 1.55 in. of precipitation was recorded. An inspection was conducted on October 15, 2012. A small amount of standing water that did not require corrective action was observed along the fence. No maintenance or repairs were required.

The first quarterly inspection was performed on December 11, 2012. The signs and fence were in good condition, and no settling, cracking, vegetation, or animal burrows were observed. No maintenance or repairs were required.

The second quarterly inspection was performed on March 12, 2013. The signs and fence were in good condition, and no settling, cracking, vegetation, or animal burrows were observed. No maintenance or repairs were required.

The third quarterly inspection was performed on June 12, 2013. The signs and fence were in good condition, and no settling, cracking, or animal burrows were observed. Vegetation was present on the cover that required removal. The vegetation was removed on July 9, 2013.

On September 1, 2013, 0.96 in. of precipitation was recorded. An inspection was conducted on September 3, 2013. A small amount of standing water that did not require corrective action was observed along the fence, and vegetation was present on the cover that did not require removal at that time. No maintenance or repairs were required.

The fourth quarterly inspection was performed on September 18, 2013. The signs and fence were in good condition, and no settling, cracking, or animal burrows were observed. Dead vegetation was present that required removal. Vegetation removal was completed within 60 days and will be reported in the next annual report.

\subsection{Corrective ACTIOn Unit 110, Area 3 WMD U-3AX/Bl Crater}

\subsubsection{Post-Closure Requirements}

Quarterly inspections are required evaluate the condition of the cover. Photographs are taken, and the results of the inspections are documented on a checklist. The condition of the fence, use restriction warning signs, entrance gate, and lock is documented. The seven subsidence markers (SMs) are inspected, and any changes in the condition of the cover, including, but not limited to, trash or debris within the fenced area, erosion of the cover, and animal burrows or nesting activity, are documented. Non-critical cracks or settling imperfections (equal to or less than 6 in. deep) on the cover are documented, and repairs are scheduled on an annual basis. Cracks or settling imperfections greater than 6 in. deep that extend 3 feet $(\mathrm{ft})$ or more are reported to NDEP and repaired within 60 days of discovery.

\subsubsection{Inspections, Repairs, and Maintenance}

Subsidence that was observed in September 2012 was repaired on October 15, 2012. The first quarterly inspection was performed on December 11, 2012. The signs were in good condition, 
and the vegetation appeared to be healthy. A substantial number of animal burrows were present on the cover. It was recommended to evaluate the burrows during the next inspection. The chicken wire on the fence was down in two locations; however, it was determined that the chicken wire can be removed from the fence during future required repairs. A small crack was observed that did not require repair. It was recommended to monitor this crack during future inspections. No maintenance or repairs were required.

The second quarterly inspection was performed on March 12, 2013. The signs and fence were in good condition. There was no change in the animal burrows from the December inspection. It was recommended to evaluate the burrows during the vegetation evaluation to determine if trapping and relocation is required. The small crack that was observed during the December inspection had not changed. It was recommended to continue to monitor this crack during future inspections. No maintenance or repairs were required.

The third quarterly inspection was performed on June 12, 2013. The red "WARNING" text on four of the signs was faded. New "WARNING" stickers were placed on the signs during the inspection. The hinges on the gate were observed to be damaged. Several small cracks less than 6 in. deep were observed on the east end of the cover. The hinges and the cracks were repaired on July 23, 2013.

The fourth quarterly inspection was performed on September 17, 2013. The signs and fence were in good condition. Two areas of subsidence were observed that required repair. Erosion rills were also observed on the south slope of the cover. The areas of subsidence and erosion rills were repaired within 60 days and will be reported in the next annual report.

\subsection{Corrective Action Unit 111, Area 5 WMd Retired MiXed Waste PITS}

\subsubsection{Post-Closure Requirements}

Quarterly inspections are required to verify that the use restriction warning signs are in place and readable and that the use restriction has been maintained. Photographs are taken, and the results of the inspections are documented on a checklist. The covers are inspected for cracks, animal burrows, or other evidence of subsidence or erosion. In addition, non-scheduled inspections are conducted if precipitation occurs in excess of 1.0 inch in a 24-hour period to verify the continued integrity of the covers and document any ponding or erosion. Maintenance or repair requirements are reported to NDEP and completed within 60 days of discovery.

\subsubsection{Inspections, Repairs, and Maintenance}

An area of subsidence and a fracture that were observed in September 2012 were repaired on October 16, 2012. An unscheduled inspection was performed on October 8, 2012, to evaluate subsidence that had been observed during a previous walkdown for required repairs. Four areas of subsidence were observed on the west cover. The subsidence areas were repaired on November 18, 2012.

On October 11, 2012, 0.32 in. of precipitation was recorded. Although not required, an inspection was conducted as a best management practice on October 15, 2012. Erosion rills were observed on the side slopes of the south and west covers. The erosion was repaired on November 13, 2012. 
The first quarterly inspection was performed on December 18, 2012. The signs and monuments were in good condition, and no settling, cracking, or animal burrows were observed. No maintenance or repairs were required.

The second quarterly inspection was performed on March 12, 2013. The signs and monuments were in good condition, and no animal burrows were observed. Four fractures were observed on the west cover. The fractures were repaired on March 21, 2013.

The third quarterly inspection was performed on June 18, 2013. The signs and monuments were in good condition. Minor animal burrows were observed. A fracture was observed on the west cover. The fracture was repaired on June 26, 2013. The vegetation on the covers appeared to be dead. Remedial revegetation of the covers was recommended by the ecological specialist. Revegetation began in October 2013.

The fourth quarterly inspection was performed on September 17, 2013. The signs and monuments were in good condition. One fracture was observed on the north cover, one fracture and five areas of subsidence were observed on the west cover, and erosion rills were observed on the south and west covers. Minor animal burrows were observed. The erosion, fractures, and subsidence areas were repaired within 60 days and will be reported in the next annual report.

\subsection{Corrective ACtion Unit 112, Area 23 Hazardous Waste Trenches}

\subsubsection{Post-Closure Requirements}

Quarterly inspections are required to evaluate the condition of the unit. The results of the inspections are documented on a checklist. The permit does not specify a time limit for repairs at CAU 112.

\subsubsection{Inspections, Repairs, and Maintenance}

A section of the barbed wire fence that was observed to be loose in September 2012 was repaired on October 4, 2012. The first quarterly inspection was performed on December 11, 2012. The signs and fence were in good condition, and no settling, cracking, vegetation, or animal burrows were observed. No maintenance or repairs were required.

The second quarterly inspection was performed on March 12, 2013. The signs and fence were in good condition, and no settling, cracking, or animal burrows were observed. Vegetation was present that required removal. The vegetation was removed on April 3, 2013.

The third quarterly inspection was performed on June 12, 2013. The signs and fence were in good condition, and no settling, cracking, or animal burrows were observed. Minor vegetation was present that did not require removal at that time. No maintenance or repairs were required.

The fourth quarterly inspection was performed on September 18, 2013. The signs and fence were in good condition, and no settling, cracking, vegetation, or animal burrows were observed. No maintenance or repairs were required. 


\subsection{SUBSIDENCE SURVEYS AND VEGETATION SURVEYS}

\subsection{Corrective ACTION Unit 110, Area 3 WMD U-3AX/Bl Crater}

\subsubsection{Subsidence Survey}

Seven SMs are installed on the cover of CAU 110. The baseline survey was conducted on December 14, 2000. Subsidence surveys are performed once every other year (biennially). A subsidence survey was not required during this reporting period. The last survey was completed on March 22, 2012, and the next survey will be conducted in approximately March 2014. The results of past surveys are tabulated in Table 1. No significant subsidence has been observed.

\subsubsection{Vegetation Survey}

The CAU 110 cover was vegetated in December 2000. Surveys are conducted annually to document the establishment of a native plant community and identify remedial actions that may be necessary to ensure the plant community persists. Vegetation monitoring has been conducted annually since 2001. In the first 5 years, significant fluctuations in plant cover and density were observed. However, over the last 6 years, perennial plant cover and density have not changed significantly. The only changes noted over the last 6 years have been fluctuations in the abundance of annual forbs, which is directly related to annual precipitation patterns.

The last survey was completed on May 8,2013 . The vegetation on the cover has become a stable plant community with persistent perennial shrubs and new plant growth. Both plant cover and density have exceeded the revegetation success standards at the site for the past several years. The presence of young plants indicates that plants growing on the cover have flowered and set seed. As a result of late summer and fall rains in 2012, there was an increase in shrub cover this year, and none of the shrubs encountered showed signs of stress. Very few invasive weeds were present on the site. Overall, there are no major concerns for the plant community that has established on the CAU 110 cover.

Because the vegetation on the CAU 110 cover is well established and there are no concerns, it is recommended that a subjective evaluation, which would include a site visit to ascertain the overall status of the plant community and identify concerns, be conducted annually, and that detailed vegetation monitoring, which would include the quantitative determination of plant cover and density, be conducted every 5 years. If concerns are noted during the annual subjective evaluations, a more detailed evaluation would be conducted and corrective measures taken as necessary. Concerns may include observable changes in the plant community or excessive herbivory or burrowing activity. It is recommended and that the next detailed quantitative vegetation survey is conducted in the spring of 2018.

\subsection{Corrective ACtion Unit 111, Area 5 WMd Retired MiXed Waste PITS}

\subsubsection{Subsidence Survey}

There are 52 SMs at CAU 111. The baseline survey was conducted on January 19, 2012.

Subsidence surveys are required annually. A subsidence survey was completed on November 14, 2012. The results are tabulated in Table 2. No significant subsidence has been observed. 
Table 1. Corrective ACtion Unit 110 Subsidence SuRVey Results

\begin{tabular}{|c|c|c|c|c|c|c|c|}
\hline \multirow{3}{*}{ DATE } & SM \#1 & SM \#2 & SM \#3 & SM \#4 & SM \#5 & SM \#6 & SM \#7 \\
\hline & \multicolumn{7}{|c|}{ Elevation at Top of Subsidence Marker ${ }^{1}$} \\
\hline & \multicolumn{7}{|c|}{ Subsidence Since December 2000 Baseline Survey (ft) } \\
\hline \multirow{2}{*}{$\begin{array}{c}\text { December } 2000 \\
\text { Baseline }\end{array}$} & $4,021.84$ & $4,021.28$ & $4,019.83$ & $4,020.99$ & $4,021.87$ & $4,019.25$ & $4,020.52$ \\
\hline & - & - & - & - & - & - & - \\
\hline \multirow{2}{*}{ July 2001} & $4,021.83$ & $4,021.28$ & $4,019.83$ & $4,020.98$ & $4,021.86$ & $4,019.24$ & $4,020.51$ \\
\hline & -0.01 & 0.00 & 0.00 & -0.01 & -0.01 & -0.01 & -0.01 \\
\hline \multirow{2}{*}{ January 2002} & $4,021.84$ & $4,021.28$ & $4,019.83$ & $4,020.98$ & $4,021.86$ & $4,019.24$ & $4,020.51$ \\
\hline & 0.00 & 0.00 & 0.00 & -0.01 & -0.01 & -0.01 & -0.01 \\
\hline \multirow{2}{*}{ September 2002} & $4,021.83$ & $4,021.27$ & $4,019.83$ & $4,020.98$ & $4,021.86$ & $4,019.24$ & $4,020.50$ \\
\hline & -0.01 & -0.01 & 0.00 & -0.01 & -0.01 & -0.01 & -0.02 \\
\hline \multirow{2}{*}{ January 2003} & $4,021.83$ & $4,021.27$ & $4,019.83$ & $4,020.98$ & $4,021.86$ & $4,019.24$ & $4,020.50$ \\
\hline & -0.01 & -0.01 & 0.00 & -0.01 & -0.01 & -0.01 & -0.02 \\
\hline \multirow{2}{*}{ July 2003} & $4,021.83$ & $4,021.27$ & $4,019.83$ & $4,020.97$ & $4,021.85$ & $4,019.24$ & $4,020.50$ \\
\hline & -0.01 & -0.01 & 0.00 & -0.02 & -0.02 & -0.01 & -0.02 \\
\hline \multirow{2}{*}{ March 2004} & $4,021.82$ & $4,021.26$ & $4,019.82$ & $4,020.97$ & $4,021.83$ & $4,019.22$ & $4,020.49$ \\
\hline & -0.02 & -0.02 & -0.01 & -0.02 & -0.04 & -0.03 & -0.03 \\
\hline \multirow{2}{*}{ September 2004} & $4,021.82$ & $4,021.26$ & $4,019.82$ & $4,020.96$ & $4,021.83$ & $4,019.23$ & $4,020.49$ \\
\hline & -0.02 & -0.02 & -0.01 & -0.03 & -0.04 & -0.02 & -0.03 \\
\hline \multirow{2}{*}{ March 2005} & $4,021.82$ & $4,021.26$ & $4,019.82$ & $4,020.96$ & $4,021.82$ & $4,019.22$ & $4,020.49$ \\
\hline & -0.02 & -0.02 & -0.01 & -0.03 & -0.05 & -0.03 & -0.03 \\
\hline \multirow{2}{*}{ September 2005} & $4,021.82$ & $4,021.26$ & $4,019.82$ & $4,020.97$ & $4,021.82$ & $4,019.23$ & $4,020.49$ \\
\hline & -0.02 & -0.02 & -0.01 & -0.02 & -0.05 & -0.02 & -0.03 \\
\hline \multirow{2}{*}{ March 2006} & $4,021.82$ & $4,021.26$ & $4,019.82$ & $4,020.96$ & $4,021.82$ & $4,019.23$ & $4,020.49$ \\
\hline & -0.02 & -0.02 & -0.01 & -0.03 & -0.05 & -0.02 & -0.03 \\
\hline \multirow{2}{*}{ September 2006} & $4,021.82$ & $4,021.25$ & $4,019.82$ & $4,020.96$ & $4,021.81$ & $4,019.22$ & $4,020.49$ \\
\hline & -0.02 & -0.03 & -0.01 & -0.03 & -0.06 & -0.03 & -0.03 \\
\hline \multirow{2}{*}{ March 2007} & $4,021.82$ & $4,021.25$ & $4,019.82$ & $4,020.96$ & $4,021.80$ & $4,019.22$ & $4,020.48$ \\
\hline & -0.02 & -0.03 & -0.01 & -0.03 & -0.07 & -0.03 & -0.04 \\
\hline \multirow{2}{*}{ September 2007} & $4,021.81$ & $4,021.25$ & $4,019.81$ & $4,020.96$ & $4,021.79$ & $4,019.22$ & $4,020.49$ \\
\hline & -0.03 & -0.03 & -0.02 & -0.03 & -0.08 & -0.03 & -0.03 \\
\hline \multirow{2}{*}{ March 2008} & $4,021.81$ & $4,021.25$ & $4,019.81$ & $4,020.95$ & $4,021.79$ & $4,019.22$ & $4,020.48$ \\
\hline & -0.03 & -0.03 & -0.02 & -0.04 & -0.08 & -0.03 & -0.04 \\
\hline \multirow{2}{*}{ September 2008} & $4,021.81$ & $4,021.25$ & $4,019.81$ & $4,020.95$ & $4,021.78$ & $4,019.21$ & $4,020.48$ \\
\hline & -0.03 & -0.03 & -0.02 & -0.04 & -0.09 & -0.04 & -0.04 \\
\hline \multirow{2}{*}{ March 2009} & $4,021.81$ & $4,021.24$ & $4,019.81$ & $4,020.95$ & $4,021.78$ & $4,019.21$ & $4,020.48$ \\
\hline & -0.03 & -0.04 & -0.02 & -0.04 & -0.09 & -0.04 & -0.04 \\
\hline \multirow{2}{*}{ September 2009} & $4,021.81$ & $4,021.24$ & $4,019.80$ & $4,020.95$ & $4,021.77$ & $4,019.22$ & $4,020.48$ \\
\hline & -0.03 & -0.04 & -0.03 & -0.04 & -0.10 & -0.03 & -0.04 \\
\hline \multirow{2}{*}{ March 2010} & $4,021.81$ & $4,021.24$ & $4,019.80$ & $4,020.95$ & $4,021.77$ & $4,019.21$ & $4,020.48$ \\
\hline & -0.03 & -0.04 & -0.03 & -0.04 & -0.10 & -0.04 & -0.04 \\
\hline \multirow{2}{*}{ September 2010} & $4,021.81$ & $4,021.24$ & $4,019.80$ & $4,020.95$ & $4,021.77$ & $4,019.21$ & $4,020.48$ \\
\hline & -0.03 & -0.04 & -0.03 & -0.04 & -0.10 & -0.04 & -0.04 \\
\hline
\end{tabular}




\begin{tabular}{|c|c|c|c|c|c|c|c||}
\hline \multirow{3}{*}{ DATE } & SM \#1 & SM \#2 & SM \#3 & SM \#4 & SM \#5 & SM \#6 & SM \#7 \\
\cline { 2 - 8 } & \multicolumn{7}{|c||}{ Elevation at Top of Subsidence Marker } \\
\cline { 2 - 8 } & \multicolumn{7}{|c||}{ Subsidence Since December 2000 Baseline Survey (ft) } \\
\hline \hline \multirow{2}{*}{ March 2011 } & $4,021.79$ & $4,021.22$ & $4,019.79$ & $4,020.93$ & $4,021.75$ & $4,019.20$ & $4,020.46$ \\
\cline { 2 - 8 } & -0.05 & -0.06 & -0.04 & -0.06 & -0.12 & -0.05 & -0.06 \\
\hline \multirow{2}{*}{ September 2011 } & $4,021.79$ & $4,021.22$ & $4,019.79$ & $4,020.93$ & $4,021.74$ & $4,019.19$ & $4,020.46$ \\
\cline { 2 - 8 } & -0.05 & -0.06 & -0.04 & -0.06 & -0.13 & -0.06 & -0.06 \\
\hline \multirow{2}{*}{ March 2012 } & $4,021.79$ & $4,021.22$ & $4,019.79$ & $4,020.93$ & $4,021.74$ & $4,019.20$ & $4,020.46$ \\
\cline { 2 - 8 } & -0.05 & -0.06 & -0.04 & -0.06 & -0.13 & -0.06 & -0.06 \\
\hline
\end{tabular}

${ }^{1}$ Elevations based on North American Vertical Datum of $1929 \mathrm{in} \mathrm{ft.}$

Table 2. Corrective ACtion Unit 111 Subsidence SuRVey Results

\begin{tabular}{|c|c|c|}
\hline \multirow[b]{2}{*}{ SM } & \multicolumn{2}{|c|}{ Elevation $^{1}$} \\
\hline & $\begin{array}{c}\text { Baseline Survey - } \\
\text { January } 2012\end{array}$ & November 2012 \\
\hline P11-4 & $3,182.18$ & $3,182.17$ \\
\hline P11-3 & $3,186.61$ & $3,186.56$ \\
\hline $\mathrm{P} 11-2$ & $3,189.20$ & $3,189.16$ \\
\hline $\mathrm{P} 05-2$ & $3,191.58$ & $3,191.53$ \\
\hline CW1-1 & $3,197.01$ & $3,196.99$ \\
\hline CW1-2 & $3,197.17$ & $3,197.17$ \\
\hline $\mathrm{P} 04-2$ & $3,194.30$ & $3,194.27$ \\
\hline P04-3 & $3,190.20$ & $3,190.15$ \\
\hline P05-3 & $3,187.91$ & $3,187.87$ \\
\hline P04-4 & $3,185.91$ & $3,185.82$ \\
\hline P05-4 & $3,182.92$ & $3,182.87$ \\
\hline T07-5 & $3,191.65$ & $3,191.63$ \\
\hline T06-3 & $3,191.70$ & $3,191.67$ \\
\hline P02-1 & $3,194.13$ & $3,194.05$ \\
\hline $\mathrm{P} 02-2$ & $3,191.11$ & $3,191.08$ \\
\hline T06-4 & $3,188.24$ & $3,188.25$ \\
\hline T07-6 & $3,187.82$ & $3,187.83$ \\
\hline T04-7 & $3,188.07$ & $3,188.07$ \\
\hline T02-5 & $3,188.02$ & $3,188.03$ \\
\hline P01-2 & $3,187.86$ & $3,187.80$ \\
\hline T01-3 & $3,185.80$ & $3,185.74$ \\
\hline T01-4 & $3,185.75$ & $3,185.69$ \\
\hline P07-2 & $3,190.26$ & $3,190.20$ \\
\hline P07-1 & $3,192.37$ & $3,192.29$ \\
\hline P09-3 & $3,194.49$ & $3,194.46$ \\
\hline P09-2 & $3,194.60$ & $3,194.56$ \\
\hline P06-1 & $3,195.06$ & $3,195.00$ \\
\hline P06-2 & $3,192.78$ & $3,192.73$ \\
\hline P01-1 & $3,191.52$ & $3,191.48$ \\
\hline
\end{tabular}




\begin{tabular}{||c|c|c||}
\hline \multirow{2}{*}{ SM } & \multicolumn{2}{|c|}{ Elevation $^{\mathbf{1}}$} \\
\cline { 2 - 3 } & $\begin{array}{c}\text { Baseline Survey - } \\
\text { January 2012 }\end{array}$ & November 2012 \\
\hline \hline T02-4 & $3,191.59$ & $3,191.55$ \\
\hline T04-6 & $3,191.69$ & $3,191.66$ \\
\hline T03-3 & $3,192.59$ & $3,192.56$ \\
\hline T04-2 & $3,202.74$ & $3,202.71$ \\
\hline T01-1 & $3,201.63$ & $3,201.59$ \\
\hline T03-1 & $3,200.69$ & $3,200.65$ \\
\hline T07-2 & $3,199.40$ & $3,199.38$ \\
\hline T07-3 & $3,199.31$ & $3,199.28$ \\
\hline T03-2 & $3,200.64$ & $3,200.60$ \\
\hline T01-2 & $3,201.51$ & $3,201.49$ \\
\hline T04-4 & $3,202.71$ & $3,202.69$ \\
\hline T09-1 & $3,201.08$ & $3,201.08$ \\
\hline T08-1 & $3,198.06$ & $3,198.05$ \\
\hline T06-1 & $3,199.49$ & $3,199.51$ \\
\hline T05-1 & $3,200.57$ & $3,200.59$ \\
\hline T02-1 & $3,201.61$ & $3,201.62$ \\
\hline T04-5 & $3,202.75$ & $3,202.76$ \\
\hline T02-2 & $3,201.54$ & $3,201.60$ \\
\hline T05-2 & $3,200.65$ & $3,200.70$ \\
\hline T06-2 & $3,199.55$ & $3,199.59$ \\
\hline T08-2 & $3,196.71$ & $3,196.74$ \\
\hline P03-1 & $3,206.56$ & $3,206.59$ \\
\hline P03-2 & & $3,205.78$ \\
\hline \hline
\end{tabular}

\footnotetext{
${ }^{1}$ Elevations based on North American Vertical Datum of $1929 \mathrm{in} \mathrm{ft}$.
}

\subsubsection{Vegetation Survey}

The CAU 111 cover was vegetated in December 2011. Surveys to assess the success of the revegetation effort are required annually. The objective of vegetation monitoring during the first few years is to determine if seeds have germinated and seedlings are becoming established on the site. Monitoring was not conducted in 2012, the first growing season after seeding occurred. The first vegetation survey was completed on May 7, 2013, by sampling 40 100-meter transects located on the four covers. There were more dead plants encountered than live plants.

One possible cause of the low germination success and the subsequent low survival rate is low precipitation. The last 2 years have been among the driest years in the last decade. There was very little precipitation during the fall and early winter months immediately after seeding. Irrigation did not begin until January, and seeds may have needed more moisture in November and December to break dormancy and germinate. Previous successful reseeding projects on the Nevada National Security Site (NNSS) included fall irrigation or there was significant precipitation received in November and December immediately following seeding.

Another factor that may have played a role in the diminished germination and survival rates was the unexpected high concentration of invasive weeds on the covers. The weeds may have used a 
majority of the moisture in the soil, thus decreasing the soil moisture needed for seed germination and plant establishment of other species.

Another possible factor that may have led to the sudden and universal death of the young seedlings was low temperatures in February 2013. Temperatures dropped into the single digits for three consecutive days and may have had a detrimental effect on the young seedlings.

The cover requires remedial reclamation. The site will be re-seeded with a seed mix that includes, at a minimum, a subset of the original seed mix with emphasis on those species that did germinate and grow. The weedy species that have established on the site will be controlled using mechanical means to reduce the competition with the native vegetation. The areas of the covers infested with weeds will be disked when the plants are at peak production but prior to seed set. This operation will also serve as the disking necessary prior to seeding.

Sufficient moisture for seed germination and plant establishment is also critical. The irrigation system is still in place and will be put into operation with minimal effort and expense.

Other actions include testing samples of dead plants. Some plants on the site showed signs of a possible fungal infection. Plant samples will be sent to the Nevada Department of Agriculture Plant Pathology laboratory for testing.

Samples of seed will also be collected and tested for viability and germination. The seed requisition process includes certification for each species in the seed mix, but additional testing will ensure the quality of the seed used for remedial revegetation.

The reclamation techniques will be modified to accommodate the existing irrigation system and to address lessons learned during the first seeding effort. The first reclamation effort used native straw mulch that was blown onto the site with a straw blower and then crimped into the soil. The application of the straw mulch was hindered by the typically windy conditions at the site, and portions of the straw mulch were blown off the site onto adjacent facilities, which created a hazard and had to be removed. Instead, hydraulic straw mulch, which comprises natural straw fibers mixed with a polyacrylamide tackifier, will be used.

Different seeding and mulching methods will be tested on a small portion of the site, and the most successful system will be implemented on the remaining covers. The northern section of the north cover will be divided into four quadrants. Two quadrants will be broadcast seeded, and each will be hydromulched at a different rate. The remaining two quadrants will be hydroseeded, and each will be hydromulched at a different rate. This will create a test of four test methods. The four areas will be closely monitored to determine which method is the most successful in optimizing seed germination and plant establishment. The remaining covers will be revegetated using the most effective methodology.

Seeding and mulching of the test plots will be performed in October, and irrigation will begin in November. 
RCRA Post-Closure Report

Revision: 0

Date: January 2014

THIS PAGE INTENTIONALLY LEFT BLANK 


\subsection{CORRECTIVE ACTION UNIT 110 SOIL MOISTURE MONITORING}

The CAU 110 cover is designed to prevent infiltration into the disposal unit. The cover performance is monitored using Time Domain Reflectometry (TDR) soil water content sensors buried within the waste cover. The TDR probes are buried at depths of 1 to $8 \mathrm{ft}$ below ground surface at 1-ft intervals. The TDR probes are installed at a distance of $165 \mathrm{ft}$ from the edge of the cover. Arrays of eight probes are positioned at four locations across the cover. Figure 1 illustrates the locations of TDR probes on the cover. Moisture content data from the TDR probes are recorded on a daily basis and stored on a data logger. The data are transmitted via radio frequency and downloaded on a quarterly basis.

Precipitation data were collected from meteorological station Buster Jangle Y, located approximately 3 miles northwest of CAU 110. The precipitation data are presented in Figure 2. Graphs of the TDR-derived soil moisture content profiles, combined with the daily precipitation values, are presented in Figures 4 through 7.

Soil moisture results obtained to date indicate that the CAU 110 cover is functioning as designed. Shallow soil moisture content is variable and dependent on precipitation events and the ability of shallow root systems and evapotranspiration to remove moisture from the soil. The ability for these systems to remove moisture can be locally inhibited if animal burrowing and grazing on plants affects the root systems; therefore, animal burrows are routinely backfilled and small mammals are occasionally trapped and relocated from the cover to limit this damage.

Soil moisture contents for the TDR nests at depth are generally between 9 and 15 percent volumetric moisture content, depending on the location of the nest. Some locations show greater annual variability in moisture content; however, each location appears to have equilibrated to a consistent state for that location.

In the post-closure report for fiscal year 2009, the following compliance criterion was proposed and accepted by NDEP:

- The averaged water content of the three deepest TDR probes $(6 \mathrm{ft}, 7 \mathrm{ft}$, and $8 \mathrm{ft})$ is greater than 32 percent volumetric moisture content for a continuous 6-month period.

Using conservative assumptions for the soil properties, 32 percent volumetric moisture content equates to 80 percent saturation of the soil. If the average volumetric moisture content of the three deepest TDR probes $(6 \mathrm{ft}, 7 \mathrm{ft}$, and $8 \mathrm{ft}$ ) exceeds 32 percent for a continuous 6 -month period, the compliance criterion has been exceeded. If this occurs, NDEP will be notified, and a path forward will be proposed.

The action level is illustrated in Figures 3 through 6. The action level was not exceeded. 


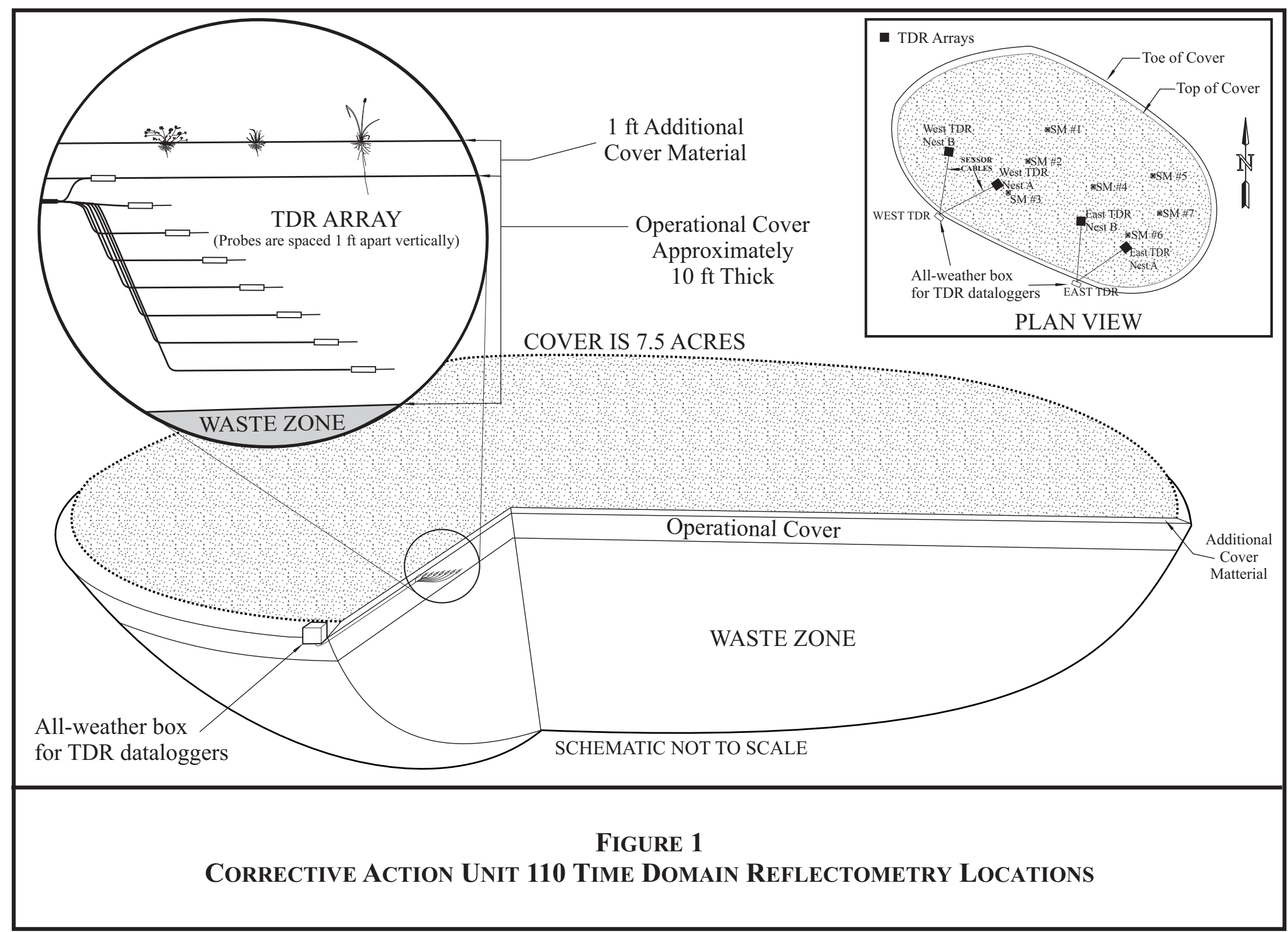




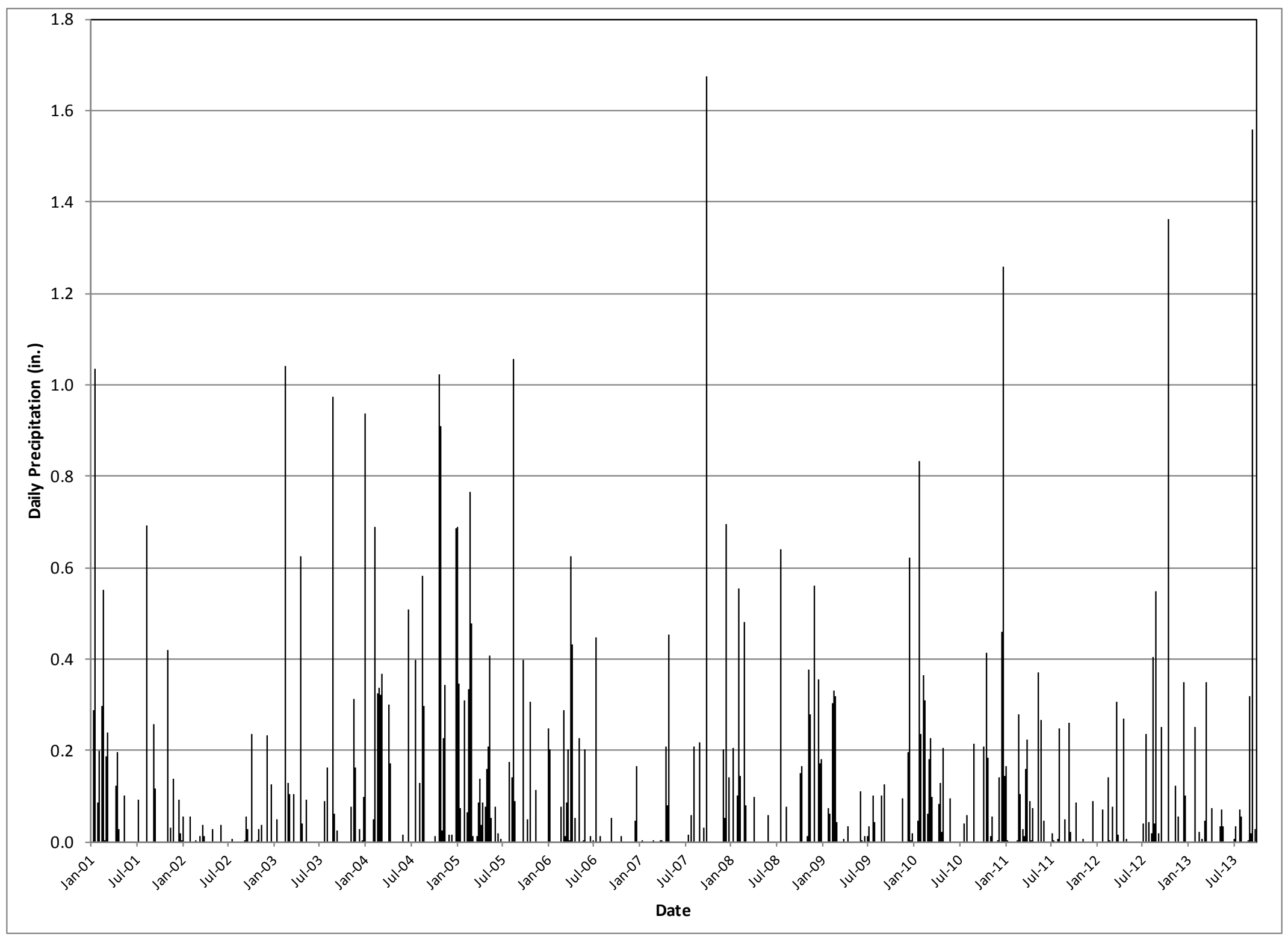

Figure 2. Precipitation Data for Meteorological Station Buster Jangle Y 


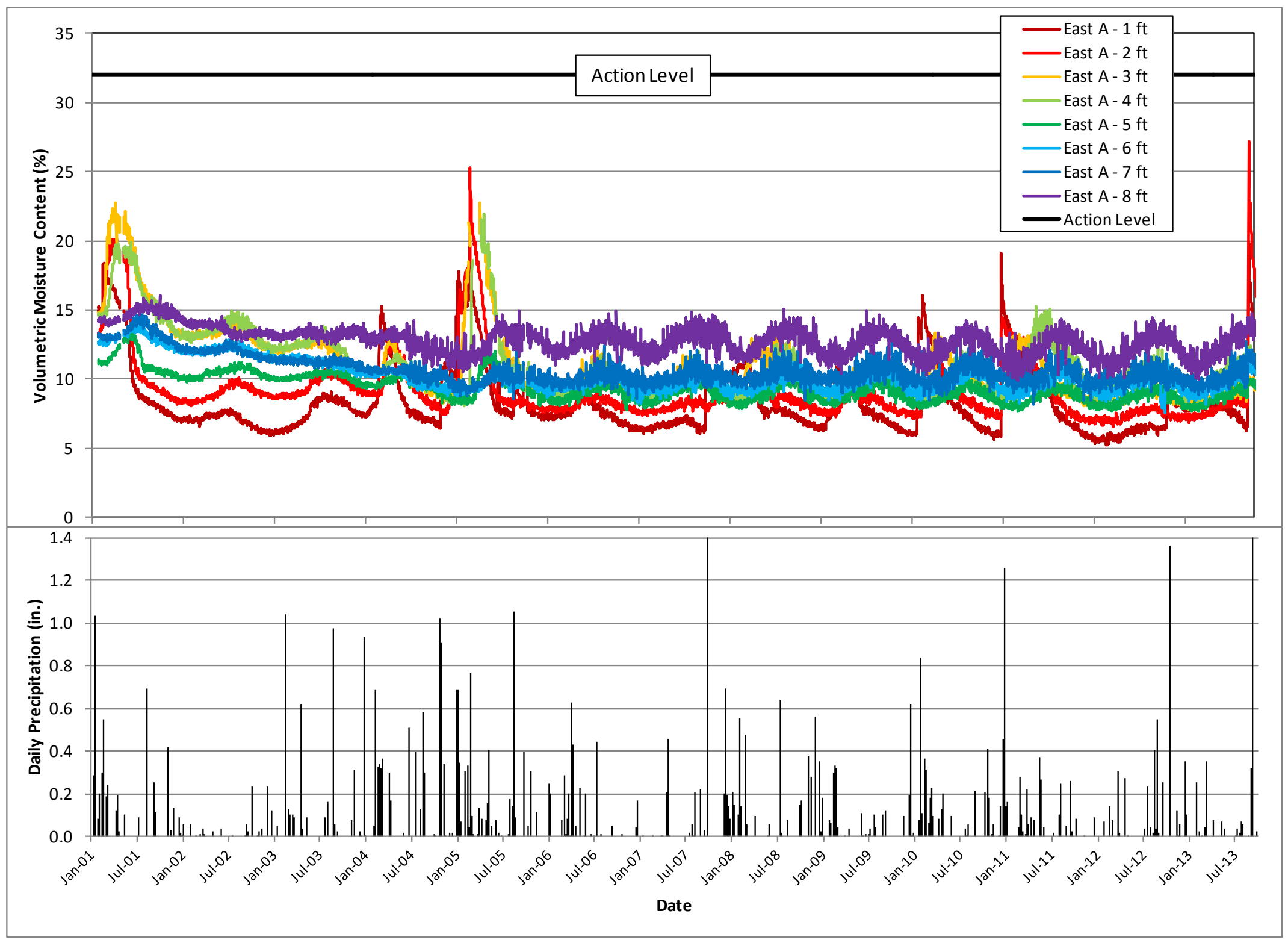

Figure 3. East TdR Nest A SoIl Moisture Content Profile 


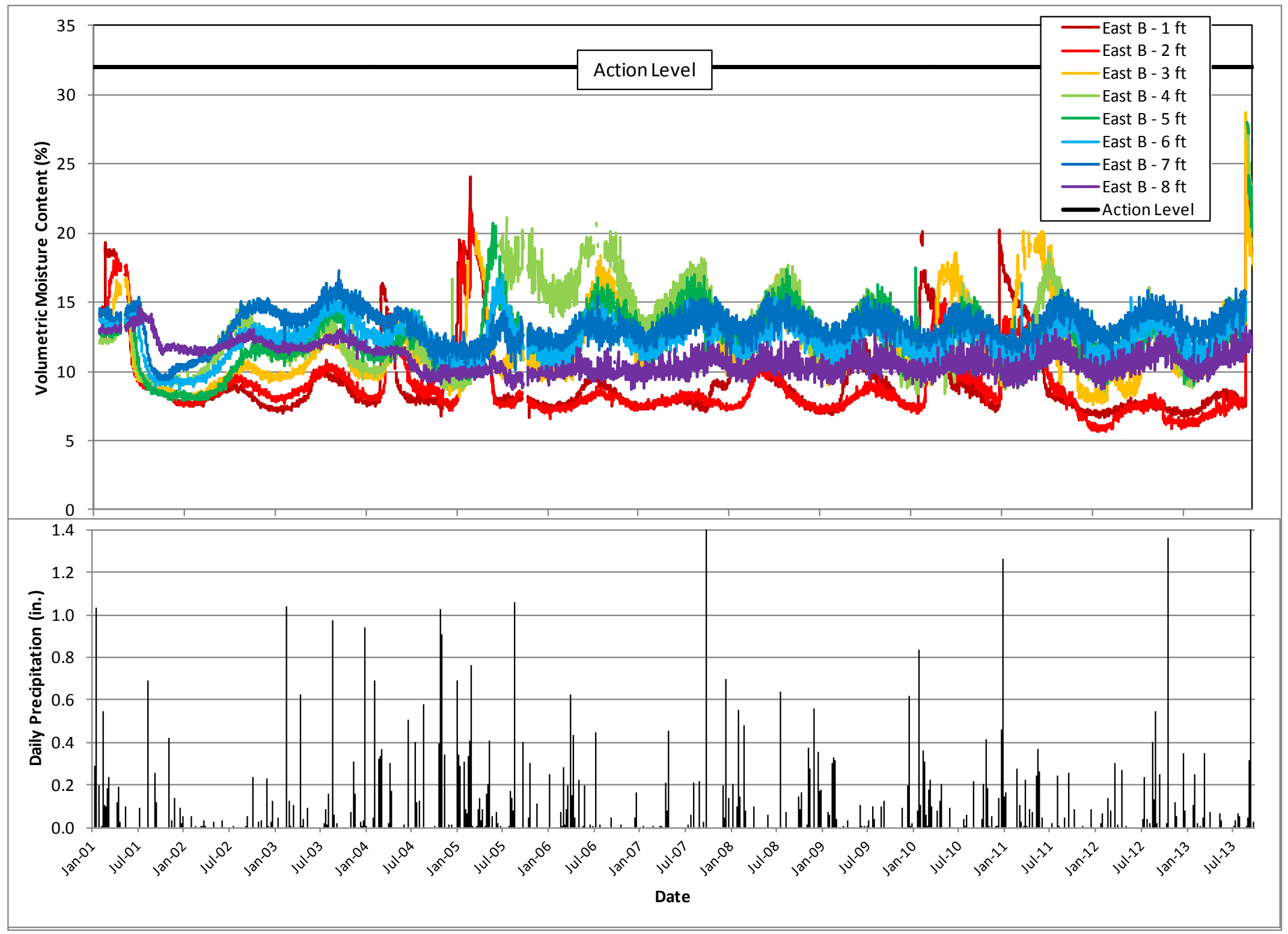

Figure 4. East TDR Nest B SoIl Moisture Content Profile 


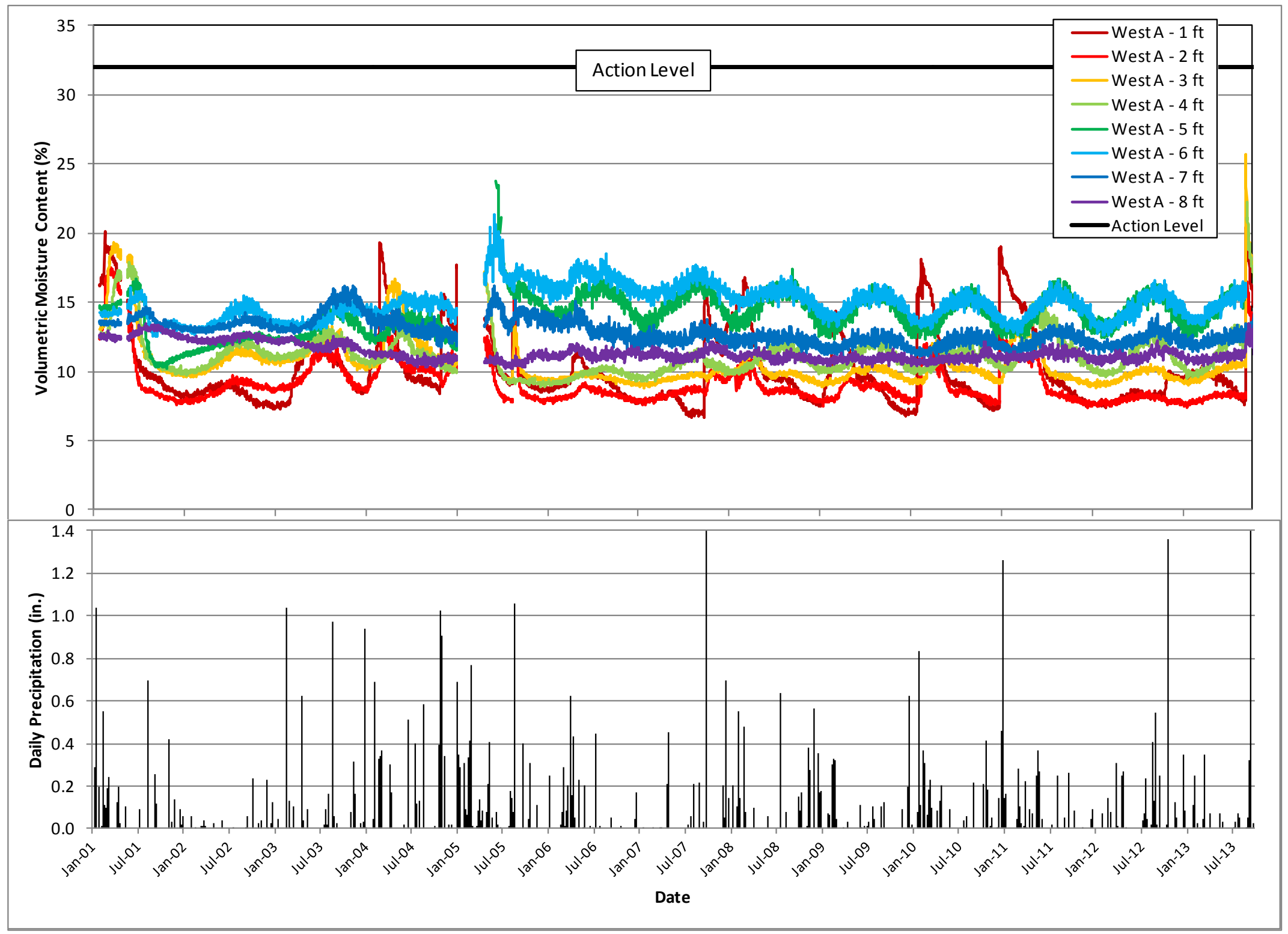

Figure 5. West TDR Nest A SoIl Moisture Content Profile 


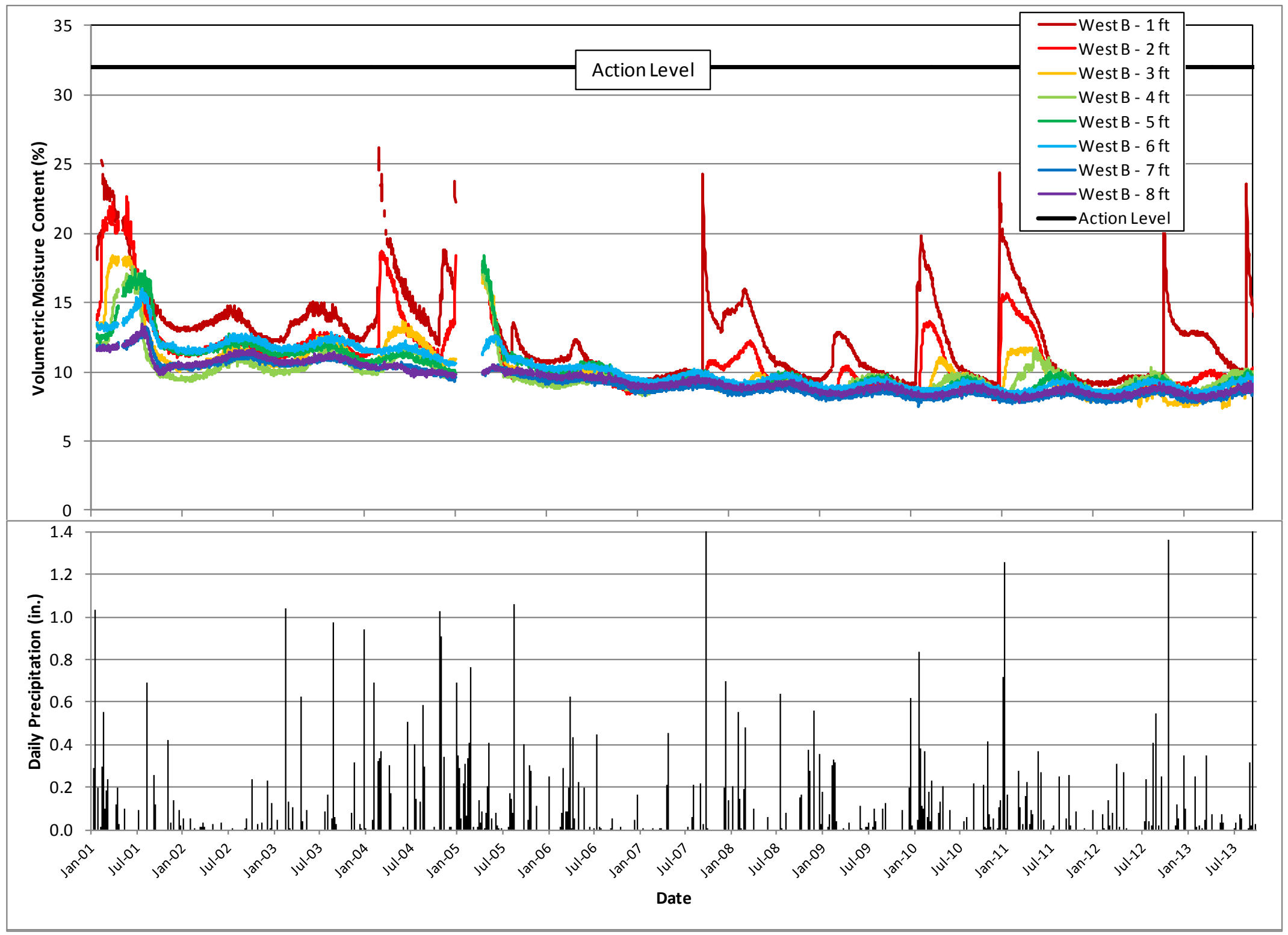

Figure 6. West TDR Nest B SoIl Moisture Content Profile 
RCRA Post-Closure Report

Revision: 0

Date: January 2014

\section{THIS PAGE INTENTIONALLY LEFT BLANK}




\subsection{CONCLUSIONS AND RECOMMENDATIONS}

\subsection{Corrective ACtion Unit 90, Area 2 Bitcutter Containment}

Semiannual inspections were performed as required. It is recommended to continue semiannual inspections.

\subsection{Corrective ACtion Unit 91, Area 3 U-3Fi InJection Well}

Semiannual inspections were performed as required. During the last inspection, vegetation was present on the cover. Vegetation removal was completed within 60 days and will be reported in the next annual report. No additional maintenance or repairs were required. It is recommended to continue semiannual inspections.

\subsection{Corrective Action Unit 92, Area 6 Decon Pond Facility}

Quarterly inspections were performed as required and after precipitation events in excess of 0.50 in. During the last inspection, dead vegetation was present on the cover. Vegetation removal was completed within 60 days and will be reported in the next annual report. No additional maintenance or repairs were required. It is recommended to continue inspections quarterly and after precipitation events.

\subsection{Corrective ACtion Unit 110, Area 3 WMD U-3AX/Bl Crater}

Quarterly inspections were performed as required. During the last inspection, two areas of subsidence and erosion rills were observed. The subsidence and erosion rills were repaired within 60 days and will be reported in the next annual report. No additional maintenance or repairs were required. Soil moisture results indicate that the cover is functioning as designed, and the action level was not exceeded. It is recommended to continue quarterly inspections, soil moisture monitoring, and biennial subsidence surveys.

Because the vegetation on the CAU 110 cover is well established and there are no concerns, it is recommended that a subjective vegetation evaluation, which would include a site visit to ascertain the overall status of the plant community and identify concerns, be conducted annually, and that detailed vegetation monitoring, which would include the quantitative determination of plant cover and density, be conducted every 5 years. It is recommended and that the next detailed quantitative vegetation survey is conducted in the spring of 2018.

\subsection{Corrective Action Unit 111, Area 5 WMd Retired MiXed Waste PITS}

Quarterly inspections were performed as required and after precipitation events in excess of 1.0 in. During the last inspection, one fracture was observed on the north cover, one fracture and five areas of subsidence were observed on the west cover, and erosion rills were observed on the south and west covers. The erosion, fractures, and subsidence areas were repaired within 60 days and will be reported in the next annual report. No additional maintenance or repairs were required. It is recommended to continue inspections quarterly and after precipitation events. 
RCRA Post-Closure Report

Date: January 2014

Results of additional monitoring at CAU 111 are documented annually in the Nevada National Security Site Waste Management Monitoring Report Area 3 and Area 5 Radioactive Waste Management Sites and in the Nevada National Security Site Data Report: Groundwater Monitoring Program Area 5 Radioactive Waste Management Site. These monitoring activities will continue as scheduled.

\subsection{Corrective ACtion Unit 112, Area 23 HaZardous Waste Trenches}

Quarterly inspections were performed as scheduled. It is recommended to continue quarterly inspections. 
RCRA Post-Closure Report

Revision: 0

Date: January 2014

\section{APPENDIX A}

\section{INSPECTION CHECKLISTS}


RCRA Post-Closure Report

Revision: 0

Date: January 2014

\section{THIS PAGE INTENTIONALLY LEFT BLANK}


RCRA Post-Closure Report

Revision: 0

Date: January 2014

\section{CORRECTIVE ACTION UNIT 90 InSPECTION CHECKLISTS}


RCRA Post-Closure Report

Revision: 0

Date: January 2014

\section{THIS PAGE INTENTIONALLY LEFT BLANK}




\section{POST-CLOSURE INSPECTION CHECKLIST}

\section{CAU 90, AREA 2 BITCUTTER CONTAINMENT -}

CAS 02-20-01, BITCUTTER/PS INJ. WELLS (3) (RCRA), AND CAS 02-20-03, WASTEWATER PIT

\begin{tabular}{|c|c|c|}
\hline Inspection Date and Time: & $9: 45$ & Semi funceal \\
\hline Date of Last Post-Closure Inspection: & $6 / 19 / 12$ & Reason for Last Post-Closure Inspection: Semie An werol \\
\hline
\end{tabular}

Responsible Entity: NSTec Environmental Restoration, Nevada National Security Site, Mercury, Nevada

Responsible Facility Owner: Thomas A. Thiele, Project Manager, Industrial Sites, Environmental Restoration Project

\begin{tabular}{|c|c|}
\hline Chief Inspector: $\quad$ \&Atruce & Title: Pleoplet Mavaser \\
\hline Assistant Inspector: $\quad$ Keed Poderes & Title: $\quad 2 / 5$ \\
\hline
\end{tabular}

- The site inspection is a walking inspection of the entire site including the perimeter and sufficient transects to be able to inspect the entire surface and all features specifically described in this checklist.

- All documentation must be legible and clear. Complete all checklist items.

- If a shaded box is checked, add detailed comments to document the results of the site inspection. Information provided should be of sufficient detail to enable reconstruction of observations regarding field conditions. The completed checklist is part of the field record of the inspection.

- Field notes taken to assist in completion of this checklist will become part of the inspection record. No form is specified for field notes, and additional field notes are not required if the checklist and associated attachments adequately describe site conditions.

\begin{tabular}{|c|c|c|c|}
\hline B. PREPARATION (To be completed prior to the site visit) & YES & NO & EXPLANATION (required if shaded box is checked) \\
\hline \multicolumn{4}{|l|}{ 1. Were anomalies or trends detected on previous inspections? } \\
\hline $\begin{array}{l}\text { 2. Were maintenance or repair activities performed since the last } \\
\text { inspection? }\end{array}$ & $V$ & & reesulation Remoral \\
\hline $\begin{array}{l}\text { a. If yes, has repair resulted in a change from as-built } \\
\text { conditions? }\end{array}$ & & $\checkmark$ & NA \\
\hline $\begin{array}{l}\text { b. If yes (to } 4 a \text { ), are revised as-built plans available that reflect } \\
\text { repair changes? }\end{array}$ & & & NA / \\
\hline
\end{tabular}

C. SITE INSPECTION (To be completed during the site visit)

1. Adjacent Offsite Features:

a. Are there any new activities or offsite features that could potentially affect the site?

2. Site Markers:

a. Is there damage to the gate or gate lock?

b. Is there damage to or a break in the fence?

c. Have any fenceposts been damaged or their anchoring weakened?

d. Are all use restriction signs legible?

e. Are any use restriction signs damaged or missing?

f. How many damaged or missing signs need to be replaced?

g. Are any use restriction signs down or loose?

h. How many down or loose signs need to be re-hung?

i. Is there damage to any of the monuments?

3. Waste Unit Covers:

a. Is there evidence of settling or cracking?

b. Is there evidence of erosion (wind or water)?

\begin{tabular}{|r|r|l||}
\hline YES & NO & EXPLANATION (required if shaded box is checked) \\
\hline & $\sqrt{ }$ & \\
\hline YES & NO & EXPLANATION (required if shaded box is checked) \\
\hline & $\sqrt{ }$ & \\
\hline & $\sqrt{ }$ & \\
\hline & & \\
\hline & $\checkmark$ & \\
\hline & 0 & \\
\hline & $\checkmark$ & \\
\hline & & \\
\hline & $\checkmark$ & \\
\hline YES & NO & EXPLANATION (required if shaded box is checked) \\
\hline & $\checkmark$ & \\
\hline & $\checkmark$ & \\
\hline
\end{tabular}

Page 1 of 2 
POST-CLOSURE INSPECTION CHECKLIST

CAU 90, AREA 2 BITCUTTER CONTAINMENT -

CAS 02-20-01, BITCUTTER/PS INJ. WELLS (3) (RCRA), AND CAS 02-20-03, WASTEWATER PIT

c. Is there evidence of human intrusion onto the site?

d. Is there evidence of large animal intrusion onto the site?

e. Is there evidence of animal burrowing?

f. Is there vegetation growing on the cover?

g. Is there trash or debris within the fenced area?

h. Are there any other issues not specifically described in this checklist?

\begin{tabular}{|l|l|l|}
\hline & $\sqrt{ }$ & \\
\hline & $\sqrt{ }$ & \\
\hline$\sqrt{ }$ & & minor - montor on neyt uspection \\
\hline$\sqrt{ }$ & & a duw small graoses \\
\hline & $\sqrt{ }$ & \\
\hline & $\sqrt{ }$
\end{tabular}

Photograph Instructions:

- The following photographs must be taken during each inspection:

- Three of the west unit from outside the fence, one in each compass direction (i.e., N, S, E)

- Three of the east unit from outside the fence, one in each compass direction (i.e., N, S, W)

- Photographs should also be taken to document maintenance/repair needs, anomalous features, or new features (such as changes in adjacent area land use). These will be used to plan maintenance/repair activities and are not intended for use in the annual post-closure report.

- Photographs will be filed electronically.

4. Photograph Documentation:

a. Have the required photographs of the site been taken?

\section{FIELD CONCLUSIONS}

1. Is general housekeeping or minor repair (including cracks or settling imperfections less than 15 centimeters deep that extend less than 1 meter on the cover) required?

2. Are there deficiencies that require a remedy other than general housekeeping or minor repair? (For example, are there cracks greater than 15 centimeters deep and 1 meter long on the cover?) Deficiencies requiring a remedy other than general housekeeping issues shall be remedied within 60 days of discovery.

3. Is there an imminent hazard to the integrity of the landfill cover?

4. Field Conclusions/Recommendations: Sigus, fencius and coures un god

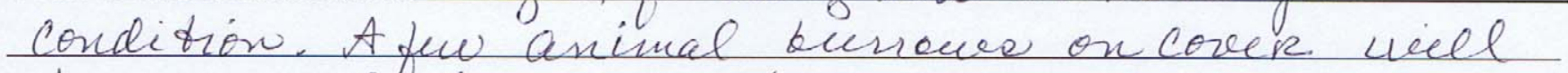

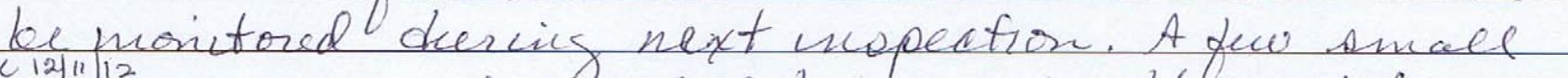

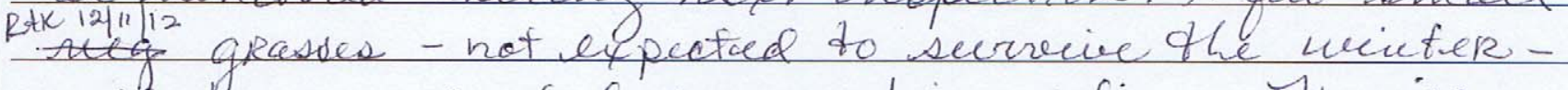

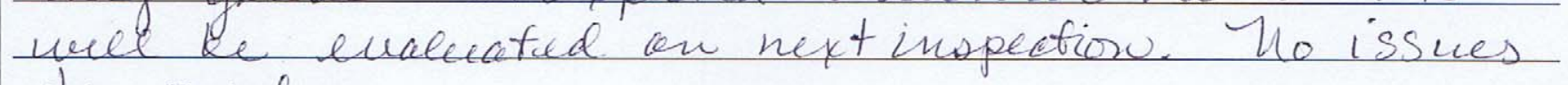
to Resolve

E. CERTIFICATION: I have conducted this inspection in accordance with the post-closure requirements as recorded on this checklist and attachments.

Chief Inspector's Signature: /S/: Rebecca King

F. VERIFICATION: I have reviewed this checklist and attachments and have verified that they are complete.

Signature: /s/: Reed Poderis

Printed Name: Thomas A. Thiele (or designec)

\begin{tabular}{|c|c|}
\hline 1 & Date: $\quad H+7 /$ rade $^{R 5 / 26 / 13}$ \\
\hline & $12 / 17 / 121$ \\
\hline
\end{tabular}




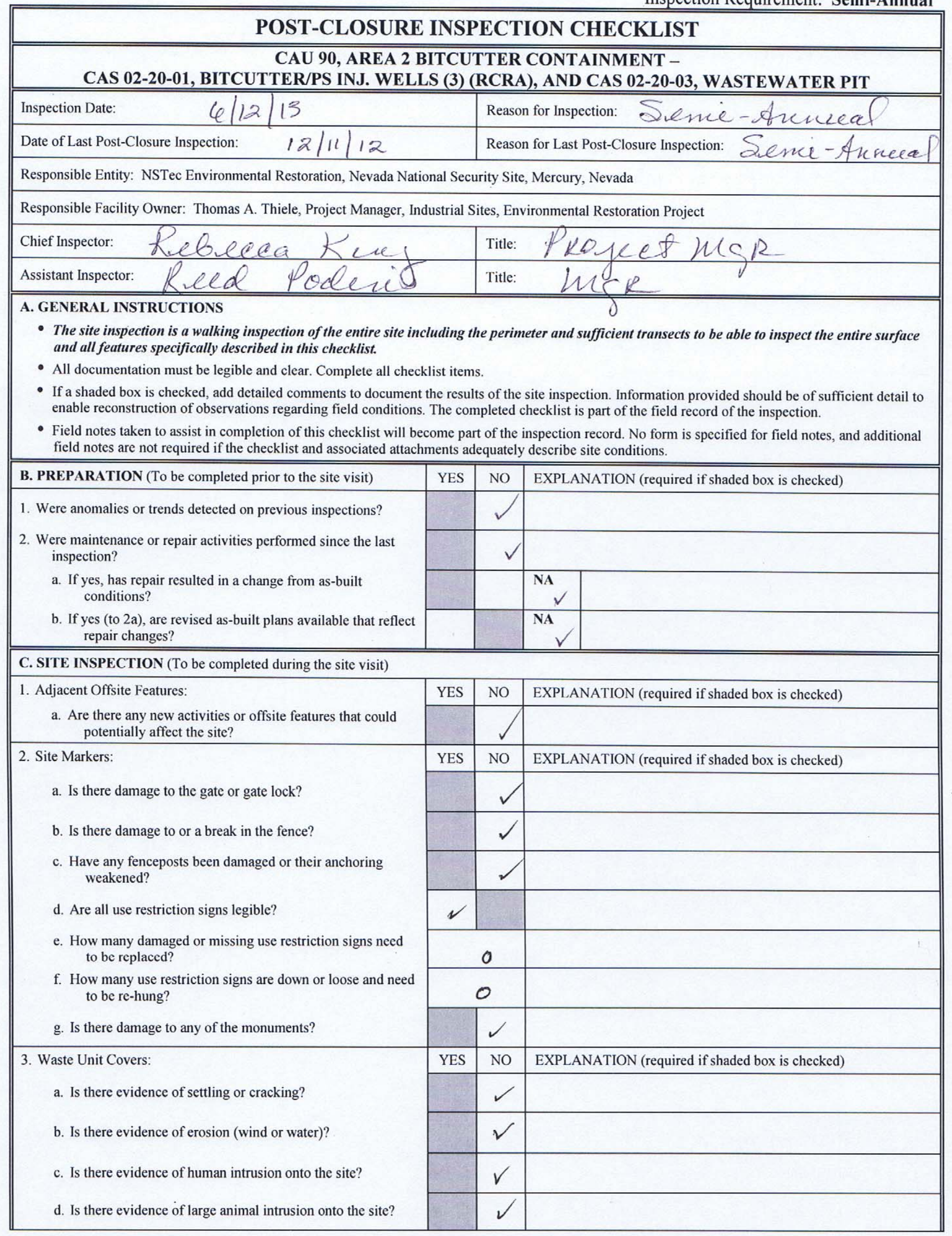

Page 1 of 2 


\begin{tabular}{l} 
POST-CLOSURE INSPECTION CHECKLIST \\
\hline \hline CAU 90, AREA 2 BITCUTTER CONTAINMENT - \\
CAS 02-20-01, BITCUTTER/PS INJ. WELLS (3) (RCRA), AND CAS 02-20-03, WASTEWATER PIT \\
\hline \hline e. Is there evidence of animal burrowing? \\
f. Is there vegetation growing on the cover? \\
$\begin{array}{l}\text { g. Is there trash or debris within the fenced area? } \\
\text { h. Are there any other issues not specifically described in this } \\
\text { checklist? }\end{array}$
\end{tabular}

\section{Photograph Instructions:}

- The following photographs must be taken during each inspection:

- Three of the west unit from outside the fence, one in each compass direction (i.e., N, S, E)

- Three of the east unit from outside the fence, one in each compass direction (i.e., N, S, W)

- Photographs should also be taken to document maintenance/repair needs, anomalous features, or new features (such as changes in adjacent area land use). These will be used to plan maintenance/repair activities and are not intended for use in the annual post-closure report.

- Photographs will be filed electronically.

4. Photograph Documentation:

a. Have the required photographs of the site been taken?

\begin{tabular}{|c|}
\hline D. FIELD CONCLUSIONS \\
\hline $\begin{array}{l}\text { 1. Is general housekeeping or minor repair (including cracks or } \\
\text { settling imperfections less than } 15 \text { centimeters deep that } \\
\text { extend less than } 1 \text { meter on the cover) required? }\end{array}$ \\
\hline $\begin{array}{l}\text { 2. Are there deficiencies that require a remedy other than general } \\
\text { housekeeping or minor repair? (For example, are there cracks } \\
\text { greater than } 15 \text { centimeters deep and } 1 \text { meter long on the } \\
\text { cover?) Deficiencies requiring a remedy other than general } \\
\text { housekeeping issues shall be remedied within } 60 \text { days of } \\
\text { discovery. }\end{array}$ \\
\hline
\end{tabular}

3. Is there an imminent hazard to the integrity of the landfill cover?

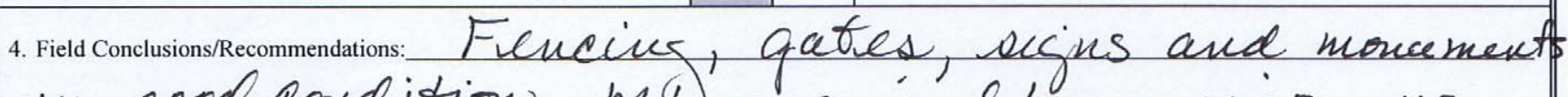

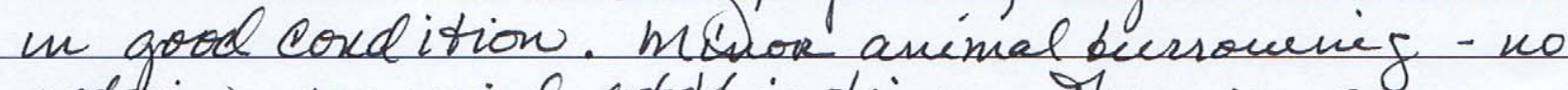
cottin vesuried cetchis time. There is rone

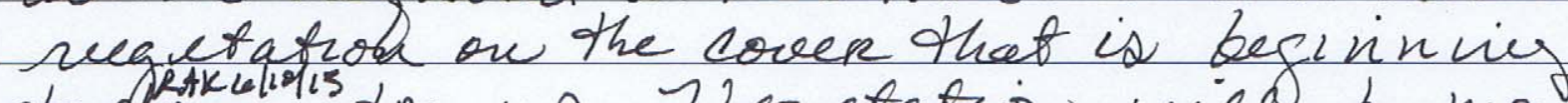

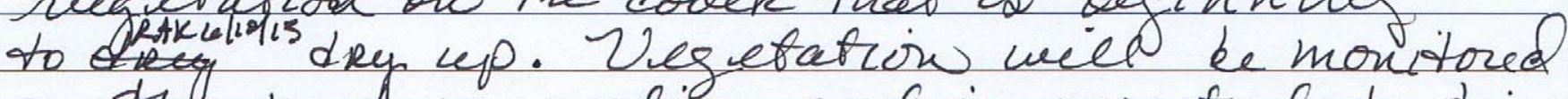
on the next unopeefion and is uppetical to die quer the punnep.

E. CERTIFICATION: I have conducted this inspection in accordance with the post-closure requirements as recorded on this checklist and attachments. Chief Inspector's Signature: /s/: Rebecca King F. VERIFICATION: I have reviewed this checklist and attachments had have verified that they are complete. Signature: /s/: Reed Poderis

Printed Name: Thomas A. Thiele (or designee) 
RCRA Post-Closure Report

Revision: 0

Date: January 2014

\section{CoRrective ACTION UnIT 91 InSPECTION CheCKLISTS}


RCRA Post-Closure Report

Revision: 0

Date: January 2014

\section{THIS PAGE INTENTIONALLY LEFT BLANK}




\section{POST-CLOSURE INSPECTION CHECKLIST}

\section{CAU 91, AREA 3 U-3FI INJECTION WELL - CAS 03-20-03, U-3FI WASTE DISPOSAL UNIT (RCRA)}

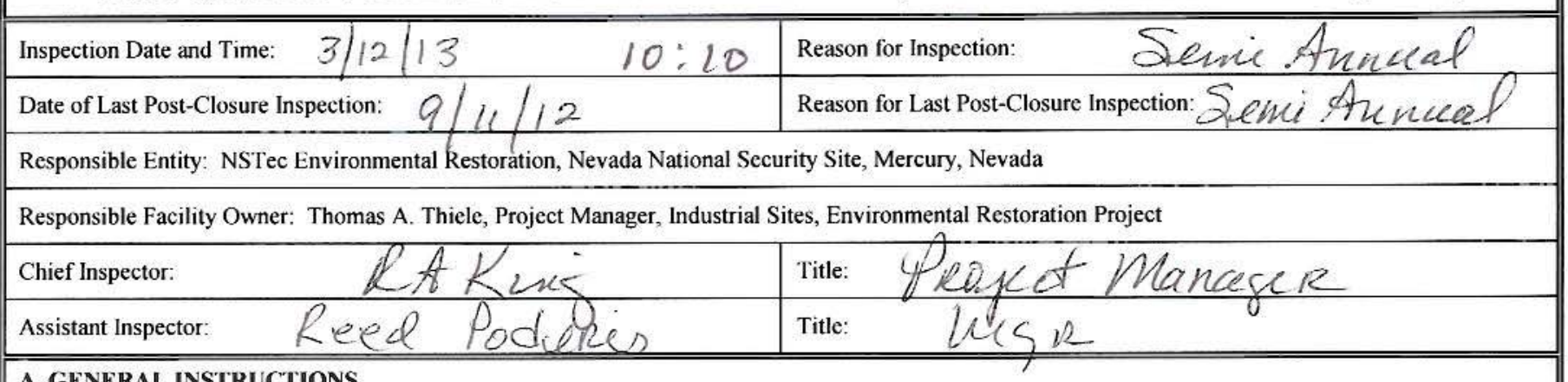

\section{A. GENERAL INSTRUCTIONS}

- The site inspection is a walking inspection of the entire site including the perimeter and sufficient transects to be able to inspect the entire surface and all features specifically described in this checklist.

- All documentation must be legible and clear. Complete all checklist items.

- If a shaded box is checked, add detailed comments to document the results of the site inspection. Information provided should be of sufficient detail to enable reconstruction of observations regarding field conditions. The completed checklist is part of the field record of the inspection.

- Field notes taken to assist in completion of this checklist will become part of the inspection record. No form is specified for field notes, and additional field notes are not required if the checklist and associated attachments adequately describe site conditions.

B. PREPARATION (To be completed prior to the site visit)

1. Were anomalies or trends detected on previous inspections?

2. Were maintenance or repair activities performed since the last inspection?

a. If yes, has site repair resulted in a change from as-built conditions?

b. If yes (to $4 a$ ), are revised as-built plans available that reflect repair changes?

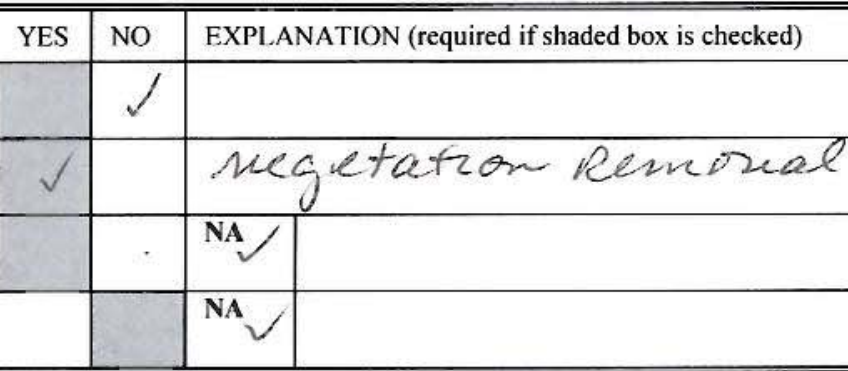

C. SITE INSPECTION (To be completed during the site visit)

1. Adjacent Offsite Features:

a. Are there any new activities or offsite features that could potentially affect the site?

2. Site Markers:

a. Is there damage to the gate or gate lock?

b. Is there damage to or a break in the fence?

c. Have any fenceposts been damaged or their anchoring weakened?

d. Are all use restriction signs legible?

e. Are any use restriction signs damaged or missing?

f. How many damaged or missing signs need to be replaced?

g. Are any use restriction signs down or loose?

h. How many down or loose signs need to be re-hung?

i. Is there damage to the monument or monitoring well?

3. Waste Unit Cover:

a. Is there evidence of settling or cracking?

b. Is there evidence of erosion (wind or water)?

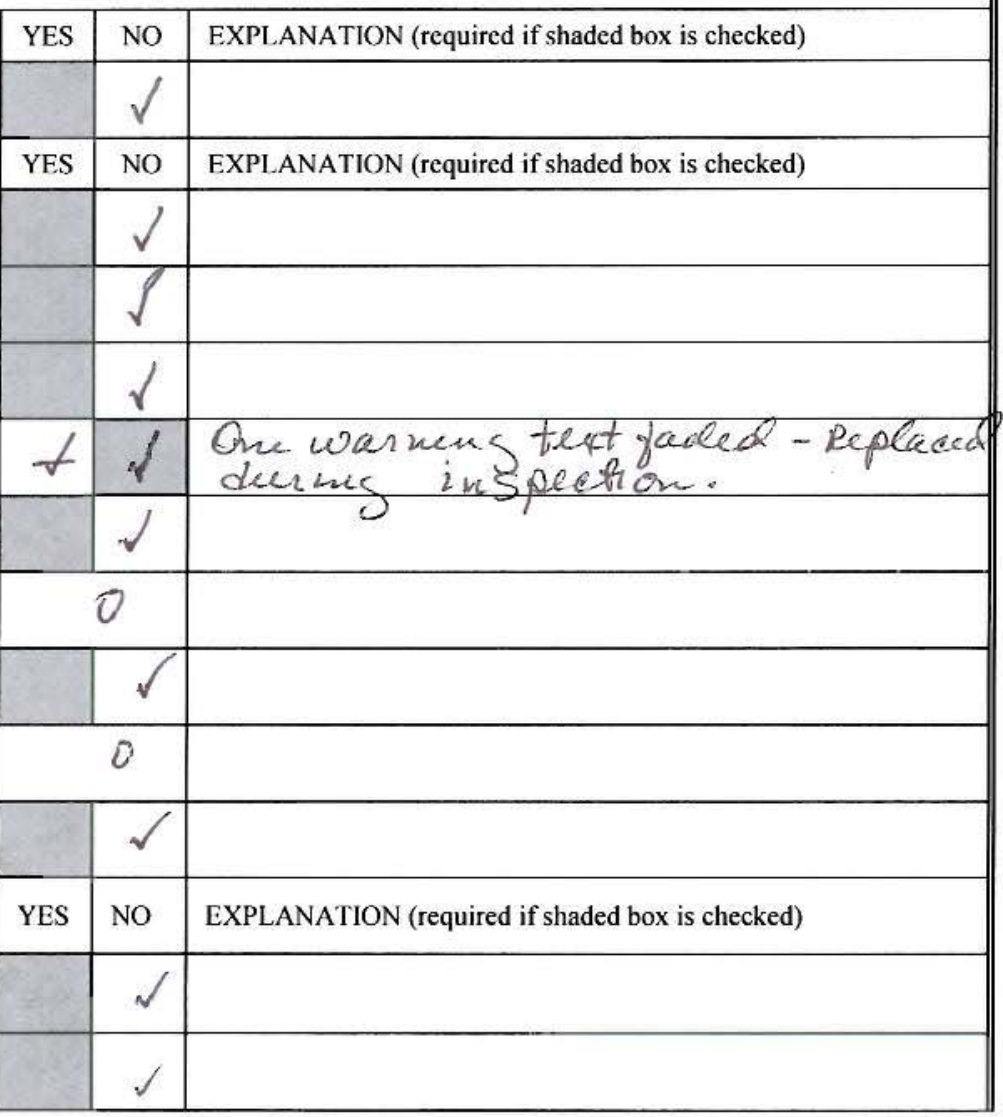




\section{POST-CLOSURE INSPECTION CHECKLIST}

\section{CAU 91, AREA 3 U-3FI INJECTION WELL - CAS 03-20-03, U-3FI WASTE DISPOSAL UNIT (RCRA)}

c. Is there evidence of human intrusion onto the site?

d. Is there evidence of large animal intrusion onto the site?

e. Is there evidence of animal burrowing?

f. Is there vegetation growing on the cover?

g. Is there trash or debris within the fenced area?

h. Are there any other issues not specifically described in this checklist?

\section{Photograph Instructions:}

- The following photographs must be taken during each inspection:

- Four from the center of the unit, one in each compass direction (i.e., N, S, E, W)

- Four of the unit from outside the fence, one in each compass direction

- Two of the monitoring well surface ( $\mathrm{N}$ and $\mathrm{S}$ )

- Photographs should also be taken to document maintenance/repair needs, anomalous features, or new features (such as changes in adjacent area land use). These will be used to plan maintenance/repair activities and are not intended for use in the annual post-closure report.

- Photographs will be filed electronically.

4. Photograph Documentation:

a. Have the required photographs of the site been taken?

\begin{tabular}{|l|l||}
\hline$\sqrt{ }$ & \\
\hline$\sqrt{ }$ & \\
\hline$\sqrt{ }$ & \\
\hline$\sqrt{ }$ & \\
\hline
\end{tabular}

D. FIELD CONCLUSIONS

1. Is maintenance/repair necessary?

2. Is there an imminent hazard to the integrity of the landfill cover?

3. Field Conclusions/Recommendations: Sighs, except ove weth faded wainis Fext, (wehich reas replaced desing nupection) are in good condition, Funce, nom chents t coreen cell in

E. CERTIFICATION: I have conducted this inspection in accordance with the post-closure requirements as recorded on this checklist and attachments.

Chief Inspector's Signature: /s/: Rebecca King

F. VERIFICATION: 1 have reviewed this checklist and attachments and have verified that they are complete.

Signature: /S/: Reed Poderis

Date: $3 / 12 / 13$

Printed Name: Thomas A. Thiele (or designee) 


\section{POST-CLOSURE INSPECTION CHECKLIST}

\section{CAU 91, AREA 3 U-3FI INJECTION WELL - CAS 03-20-03, U-3FI WASTE DISPOSAL UNIT (RCRA)}

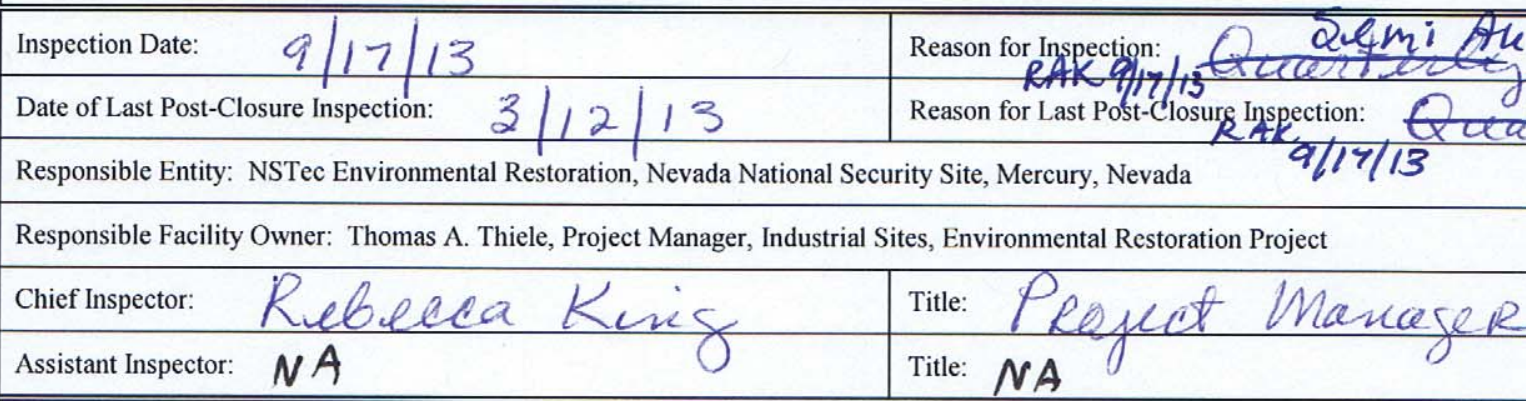

\section{A. GENERAL INSTRUCTIONS}

- The site inspection is a walking inspection of the entire site including the perimeter and sufficient transects to be able to inspect the entire surface and all features specifically described in this checklist.

- All documentation must be legible and clear. Complete all checklist items.

- If a shaded box is checked, add detailed comments to document the results of the site inspection. Information provided should be of sufficient detail to enable reconstruction of observations regarding field conditions. The completed checklist is part of the field record of the inspection.

- Field notes taken to assist in completion of this checklist will become part of the inspection record. No form is specified for field notes, and additional field notes are not required if the checklist and associated attachments adequately describe site conditions.

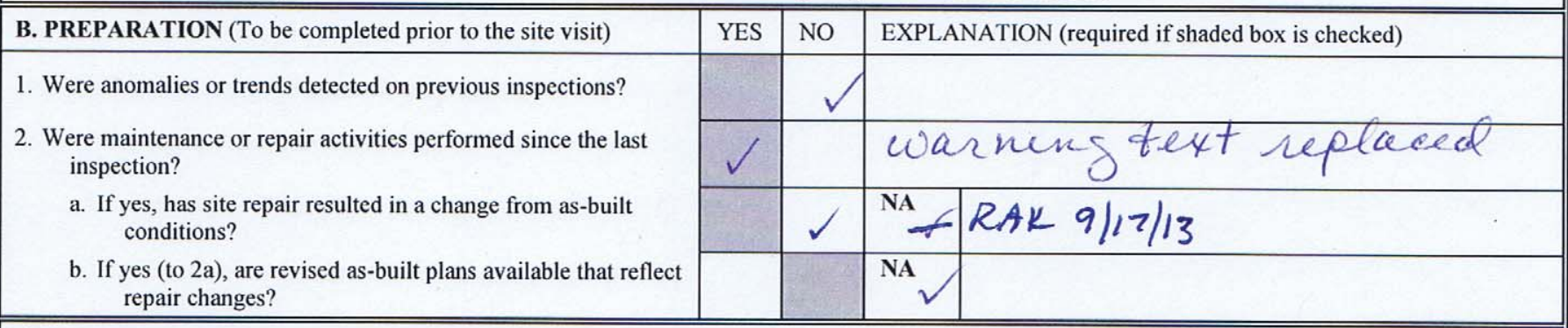

\section{SITE INSPECTION (To be completed during the site visit)}

1. Adjacent Offsite Features:

a. Are there any new activities or offsite features that could potentially affect the site?

\section{Site Markers:}

a. Is there damage to the gate or gate lock?

b. Is there damage to or a break in the fence?

c. Have any fenceposts been damaged or their anchoring weakened?

d. Are all use restriction signs legible?

e. How many damaged or missing use restriction signs need to be replaced?

f. How many use restriction signs are down or loose and need to be re-hung?

g. Is there damage to the monument or monitoring well?

3. Waste Unit Cover:

a. Is there evidence of settling or cracking?

b. Is there evidence of erosion (wind or water)?

c. Is there evidence of human intrusion onto the site?

d. Is there evidence of large animal intrusion onto the site?

\begin{tabular}{|r|r|l||}
\hline YES & NO & EXPLANATION (required if shaded box is checked) \\
\hline & & \\
\hline YES & NO & EXPLANATION (required if shaded box is checked) \\
\hline & $\checkmark$ & \\
\hline & $\checkmark$ & \\
\hline$\checkmark$ & & but 1 waikeng faded to neplace \\
\hline & 0 & \\
\hline & 0 & \\
\hline & $\checkmark$ & \\
\hline YES & NO & EXPLANATION (required if shaded box is checked) \\
\hline & $\checkmark$ & \\
\hline & $\sqrt{ }$ & \\
\hline & $\checkmark$ & \\
\hline & $\checkmark$ & \\
\hline
\end{tabular}




\section{POST-CLOSURE INSPECTION CHECKLIST}

\section{CAU 91, AREA 3 U-3FI INJECTION WELL - CAS 03-20-03, U-3FI WASTE DISPOSAL UNIT (RCRA)}

e. Is there evidence of animal burrowing?

f. Is there vegetation growing on the cover?

g. Is there trash or debris within the fenced area?

h. Are there any other issues not specifically described in this checklist?

\section{Photograph Instructions:}

- The following photographs must be taken during each inspection:

- Four from the center of the unit, one in each compass direction (i.e., N, S, E, W)

- Four of the unit from outside the fence, one in each compass direction

- Two of the monitoring well surface $(\mathrm{N}$ and $\mathrm{S})$

- Photographs should also be taken to document maintenance/repair needs, anomalous features, or new features (such as changes in adjacent area land use). These will be used to plan maintenance/repair activities and are not intended for use in the annual post-closure report.

- Photographs will be filed electronically.

4. Photograph Documentation:

a. Have the required photographs of the site been taken?

\begin{tabular}{|l|l|l|} 
& $\sqrt{ }$ & \\
\hline$\sqrt{ }$ & & rej to kemore. \\
& $\sqrt{ }$ & \\
& $\sqrt{ }$
\end{tabular}

D. FIELD CONCLUSIONS

1. Is there an imminent hazard to the integrity of the landfill cover?

\begin{tabular}{|c|c|c|}
\hline YES & NO & EXPLANATION (required if shaded box is checked) \\
\hline & & \\
\hline YES & NO & EXPLANATION (required if shaded box is checked) \\
\hline & $\checkmark$ & \\
\hline
\end{tabular}

2. Field Conclusions and Repair or Maintenance Recommendations:

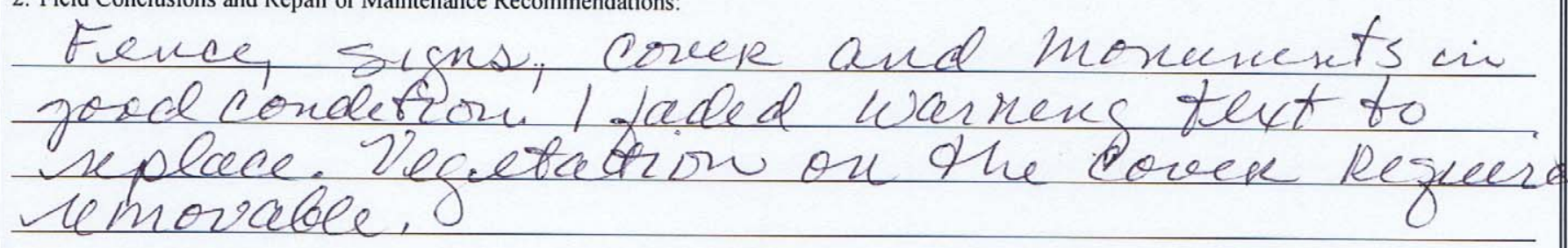

E. CERTIFICATION: I have conducted this inspection in accordance with the post-closure requirements as recorded on this checklist and attachments. Chief Inspector's Signature:/s/: Rebecca King

F. VERIFICATION: I have reviewed this checklist and attachments and have verified that they are complete.

Signature: /s/: Reed Poderis

Date: $9 / 24 / 13$

Printed Name: Thomas A. Thiele (or designee) 
RCRA Post-Closure Report

Revision: 0

Date: January 2014

\section{CORRECTIVE ACTION UnIT 92 InSPECTION CheCKLISTS}


RCRA Post-Closure Report

Revision: 0

Date: January 2014

\section{THIS PAGE INTENTIONALLY LEFT BLANK}


Inspection Requirement: Quarterly or Rain Event $>0.5$ inches in 24 hours

\section{POST-CLOSURE INSPECTION CHECKLIST}

\section{CAU 92, AREA 6 DECON POND FACILITY - CAS 06-05-02, DECONTAMINATION POND (RCRA)}

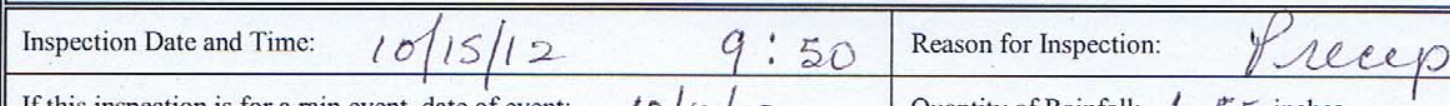

If this inspection is for a rain event, date of event: $10 / 11 / 12 \quad$ Quantity of Rainfall: 1.55 inches

$\begin{array}{lll}\text { Date of Last Post-Closure Inspection: } 9 / 13 / 12 & \text { Reason for Last Post-Closure Inspection: }\end{array}$

Responsible Entity: NSTec Environmental Restoration, Nevada National Security Site, Mercury, Nevada

Responsible Facility Owner: Thomas A. Thiele, Project Manager, Industrial Sites, Environmental Restoration Project

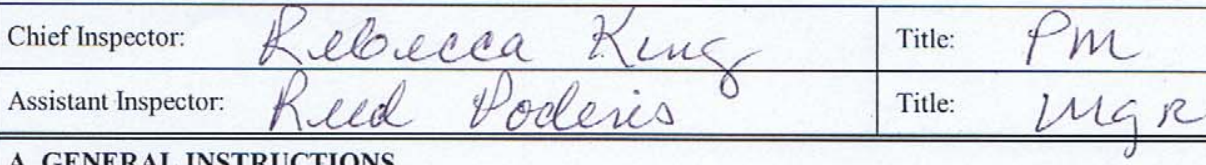

A. GENERAL INSTRUCTIONS

- The site inspection is a walking inspection of the entire site including the perimeter and sufficient transects to be able to inspect the entire surface and all features specifically described in this checklist.

- All documentation must be legible and clear. Complete all checklist items.

- If a shaded box is checked, add detailed comments to document the results of the site inspection. Information provided should be of sufficient detail to enable reconstruction of observations regarding field conditions. The completed checklist is part of the field record of the inspection.

- Field notes taken to assist in completion of this checklist will become part of the inspection record. No form is specified for field notes, and additional field notes are not required if the checklist and associated attachments adequately describe site conditions.

B. PREPARATION (To be completed prior to the site visit)

1. Were anomalies or trends detected on previous inspections?

2. Were maintenance or repair activities performed since the last inspection?

a. If yes, has repair resulted in a change from as-built conditions?

b. If yes (to $4 a$ ), are revised as-built plans available that reflect repair changes?

\begin{tabular}{|c|c|c|}
\hline YES & $\mathrm{NO}$ & EXPLANATION (required if shaded box is checked) \\
\hline & $\checkmark$ & \\
\hline$V$ & & zetafion Remsorat \\
\hline & & NA RAK $10(15) 12$ \\
\hline & & NA \\
\hline
\end{tabular}

C. SITE INSPECTION (To be completed during the site visit)

1. Adjacent Offsite Features:

a. Are there any new activities or offsite features that could potentially affect the site?

2. Site Markers:

a. Is there damage to the gate or gate lock?

b. Is there damage to or a break in the fence?

c. Have any fenceposts been damaged or their anchoring weakened?

d. Are all use restriction signs legible?

e. Are any use restriction signs damaged or missing?

f. How many damaged or missing signs need to be replaced?

g. Are any use restriction signs down or loose?

h. How many down or loose signs need to be re-hung?

i. Do any Underground Radioactive Material Area signs need to be replaced or re-hung?

j. Is there damage to any of the subsidence survey markers?

$\mathrm{k}$. Is there standing water within the fenced area?

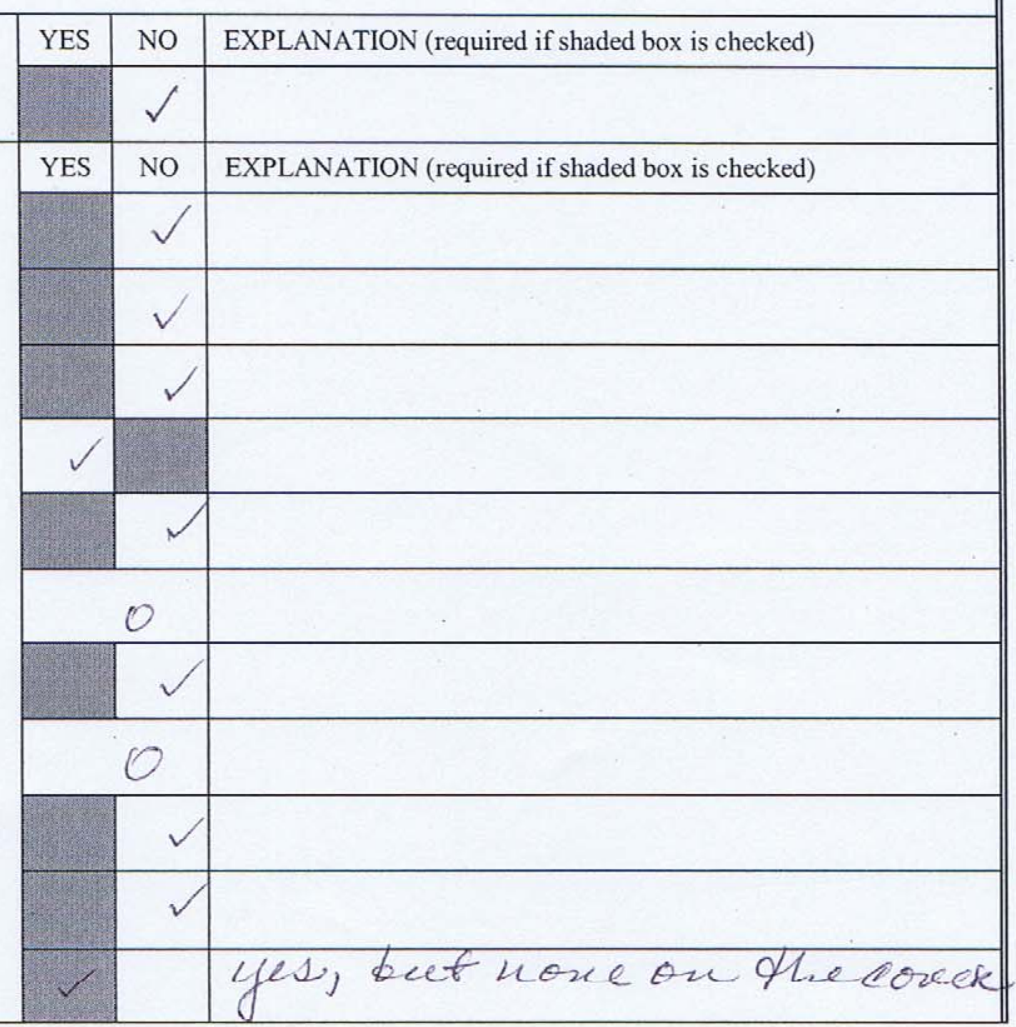

Page 1 of 3 
Inspection Requirement: Quarterly or Rain Event $>0.5$ inches in 24 hours

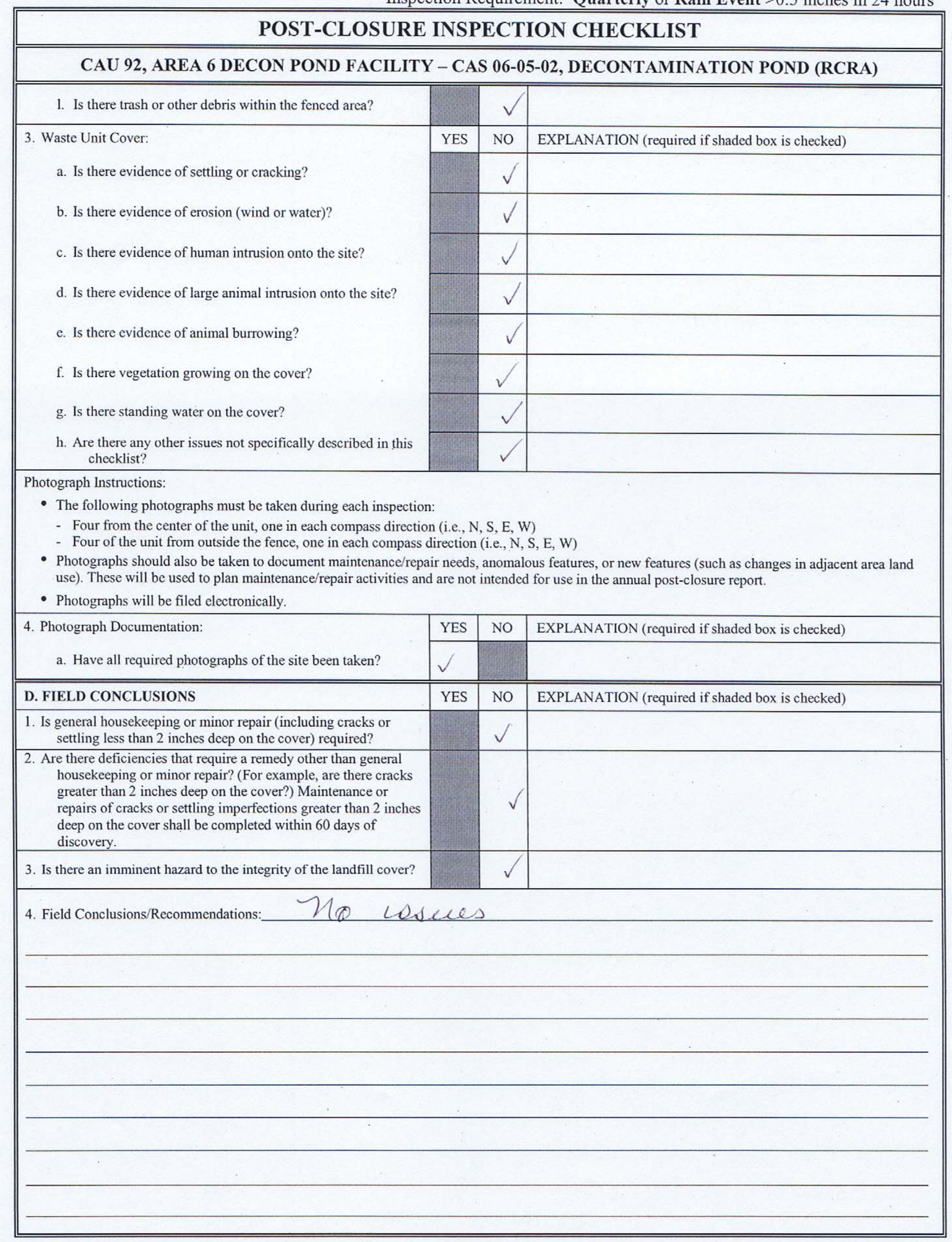


Inspection Requirement: Quarterly or Rain Event $>0.5$ inches in 24 hours

\begin{tabular}{||l|l||}
\hline \multicolumn{2}{|c||}{ POST-CLOSURE INSPECTION CHECKLIST } \\
\hline \hline \multicolumn{2}{|c||}{ CAU 92, AREA 6 DECON POND FACILITY - CAS 06-05-02, DECONTAMINATION POND (RCRA) } \\
\hline \hline E. CERTIFICATION: I have conducted this inspection in accordance with the post-closure requirements as recorded on this checklist and attachments. \\
\hline Chief Inspector's Signature: /S/: Rebecca King & Date: $/ 0 / 15 / 12$ \\
\hline \hline F. VERIFICATION: I have reviewed this checklist and attachments and have verified that they are complete. & Date: \\
\hline Signature: /S/: Reed Poderis & \\
\hline Printed Name: Thomas A. Thiele (or designee) & \\
\hline \hline
\end{tabular}




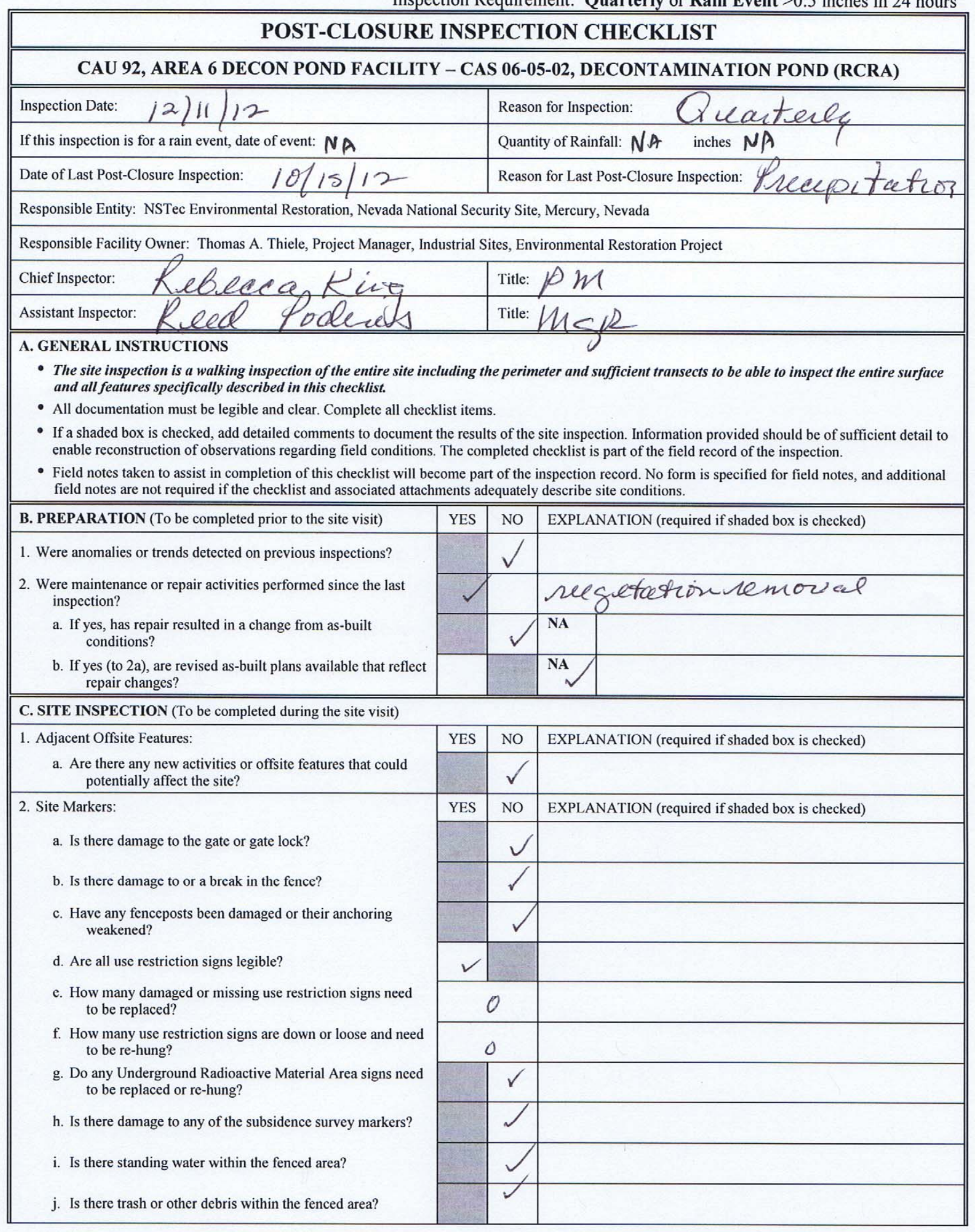


Inspection Requirement: Quarterly or Rain Event $>0.5$ inches in 24 hours

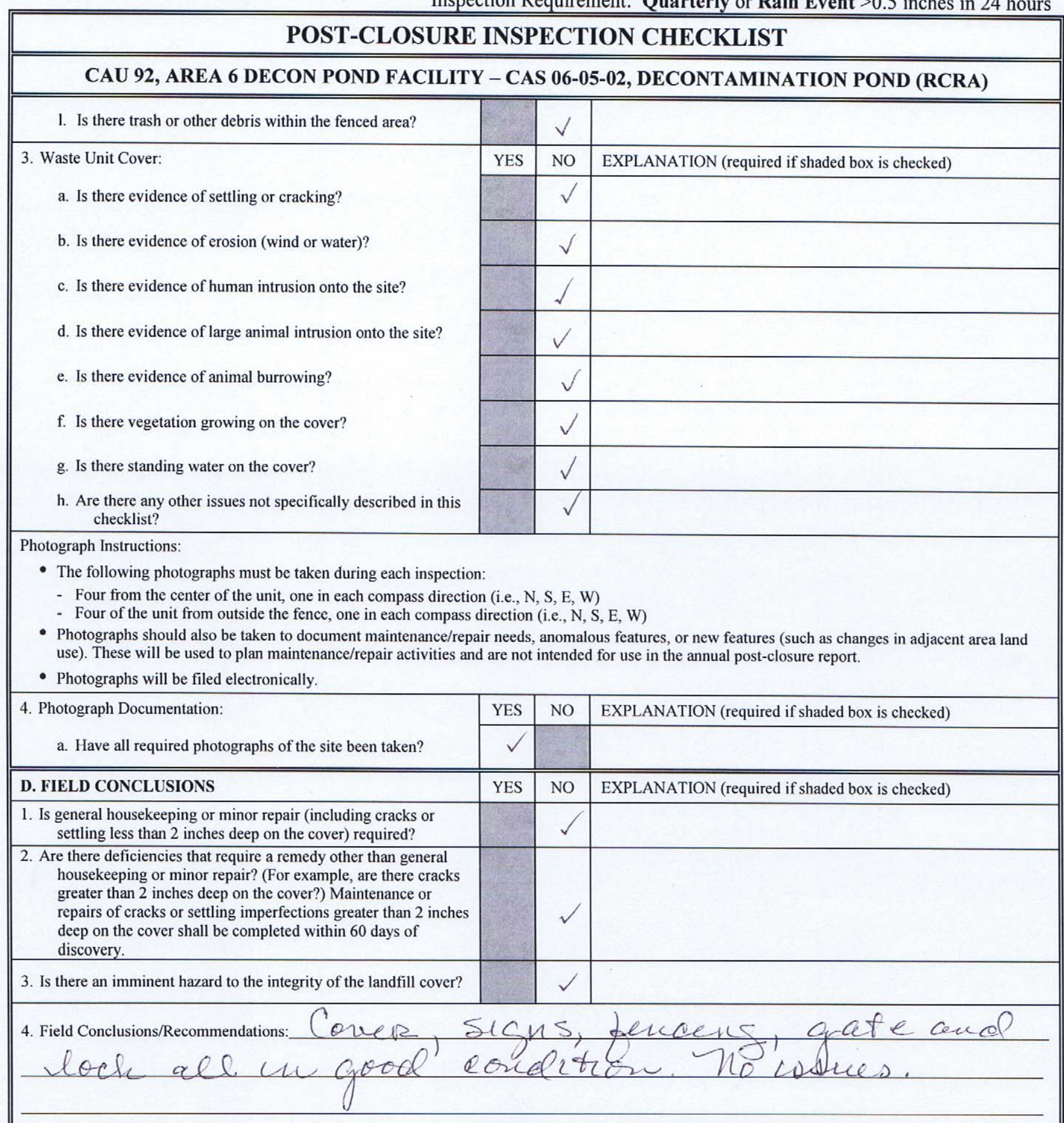


Inspection Requirement: Quarterly or Rain Event $>0.5$ inches in 24 hours

\begin{tabular}{|c|c|}
\hline \multicolumn{2}{|c|}{ POST-CLOSURE INSPECTION CHECKLIST } \\
\hline \multicolumn{2}{|c|}{ CAU 92, AREA 6 DECON POND FACILITY - CAS 06-05-02, DECONTAMINATION POND (RCRA) } \\
\hline \multicolumn{2}{|c|}{ E. CERTIFICATION: I have conducted this inspection in accordance with the post-closure requirements as recorded on this checklist and attachmen } \\
\hline Chief Inspector's Signature: /s/: Rebecca King & Date: $12111 / 2$ \\
\hline \multicolumn{2}{|c|}{ F. VERIFICATION: I have reviewed this checklist and attachments and have verified that they are complete. } \\
\hline Signature: /s/: Reed Poderis & Date: $12 / 17 / 2$ \\
\hline
\end{tabular}


Inspection Requirement: Quarterly or Rain Event $>0.5$ inches in 24 hours

POST-CLOSURE INSPECTION CHECKLIST

CAU 92, AREA 6 DECON POND FACILITY - CAS 06-05-02, DECONTAMINATION POND (RCRA)

\begin{tabular}{|l|l|l|}
\hline Inspection Date and Time: & Quantity of Rainfall: \\
\hline Date of Last Post-Closure Inspection: & Reason for Last Post-Closure Inspection: \\
\hline Responsible Entity: NSTec Environmental Restoration, Nevada National Security Site, Mercury, Nevada
\end{tabular}

Responsible Facility Owner: Thomas A. Thiele, Project Manager, Industrial Sites, Environmental Restoration Project

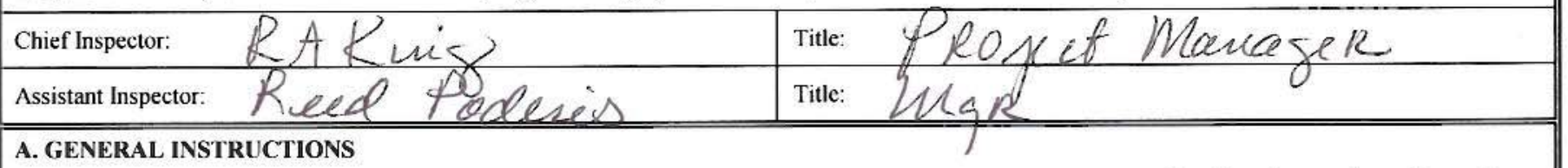

A. GENERAL INSTRUCTIONS

- The site inspection is a walking inspection of the entire site including the perimeter and sufficient transects to be able to inspect the entire surface and all features specifically described in this checklist.

- All documentation must be legible and clear. Complete all checklist items.

- If a shaded box is checked, add detailed comments to document the results of the site inspection. Information provided should be of sufficient detail to enable reconstruction of observations regarding field conditions. The completed checklist is part of the field record of the inspection.

- Field notes taken to assist in completion of this checklist will become part of the inspection record. No form is specified for field notes, and additional field notes are not required if the checklist and associated attachments adequately describe site conditions.

B. PREPARATION (To be completed prior to the site visit)

1. Were anomalies or trends detected on previous inspections?

2. Were maintenance or repair activities performed since the last inspection?

a. If yes, has repair resulted in a change from as-built conditions?

b. If yes (to $4 a$ ), are revised as-built plans available that reflect repair changes?

\begin{tabular}{|c|c|c|c|}
\hline YES & NO & EXPLANATION (required if shaded box is checked) \\
\hline & $\checkmark$ & \multicolumn{2}{|l|}{} \\
\hline & $\checkmark$ & \multicolumn{2}{|l|}{} \\
\hline & & NA & \\
\hline & & NA & \\
\hline
\end{tabular}

C. SITE INSPECTION (To be completed during the site visit)

1. Adjacent Offsite Features:

a. Are there any new activities or offsite features that could potentially affect the site?

2. Site Markers:

a. Is there damage to the gate or gate lock?

b. Is there damage to or a break in the fence?

c. Have any fenceposts been damaged or their anchoring weakened?

d. Are all use restriction signs legible?

e. Are any use restriction signs damaged or missing?

f. How many damaged or missing signs need to be replaced?

g. Are any use restriction signs down or loose?

h. How many down or loose signs need to be re-hung?

i. Do any Underground Radioactive Material Area signs need to be replaced or re-hung?

j. Is there damage to any of the subsidence survey markers?

k. Is there standing water within the fenced area?

\begin{tabular}{|r|r|l||}
\hline YES & NO & EXPLANATION (required if shaded box is checked) \\
\hline & $\checkmark$ & \\
\hline & $\sqrt{ }$ & \\
\hline & $\sqrt{ }$ & \\
\hline & $\checkmark$ & \\
\hline & NO & EXPLANATION (required if shaded box is checked) \\
\hline & $\checkmark$ & \\
\hline & 0 & \\
\hline & $\checkmark$ & \\
\hline & & \\
\hline & $\checkmark$ & \\
\hline & $\checkmark$ & \\
\hline & & \\
\hline
\end{tabular}


POST-CLOSURE INSPECTION CHECKLIST

\section{CAU 92, AREA 6 DECON POND FACILITY - CAS 06-05-02, DECONTAMINATION POND (RCRA)}

1. Is there trash or other debris within the fenced area?

3. Waste Unit Cover:

a. Is there evidence of settling or cracking?

b. Is there evidence of erosion (wind or water)?

c. Is there evidence of human intrusion onto the site?

d. Is there evidence of large animal intrusion onto the site?

e. Is there evidence of animal burrowing?

f. Is there vegetation growing on the cover?

g. Is there standing water on the cover?

h. Are there any other issues not specifically described in this checklist?

\begin{tabular}{|r|r|l|}
\hline & $\checkmark$ & \\
\hline YES & NO & EXPLANATION (required if shaded box is checked) \\
\hline & $\checkmark$ & \\
\hline & $\checkmark$ & \\
\hline & $\checkmark$ & \\
\hline & $\checkmark$ & \\
\hline & $\checkmark$ & \\
\hline & $\checkmark$ & \\
\hline & $\checkmark$ & \\
\hline & $\checkmark$ & \\
\hline
\end{tabular}

Photograph Instructions:

- The following photographs must be taken during each inspection:

- Four from the center of the unit, one in each compass direction (i.e., N, S, E, W)

- Four of the unit from outside the fence, one in each compass direction (i.e., N, S, E, W)

- Photographs should also be taken to document maintenance/repair needs, anomalous features, or new features (such as changes in adjacent area land use). These will be used to plan maintenance/repair activities and are not intended for use in the annual post-closure report.

- Photographs will be filed electronically.

4. Photograph Documentation:

a. Have all required photographs of the site been taken?

\section{FIELD CONCLUSIONS}

1. Is general housekeeping or minor repair (including cracks or settling less than 2 inches deep on the cover) required?

2. Are there deficiencies that require a remedy other than general housekeeping or minor repair? (For example, are there cracks greater than 2 inches deep on the cover?) Maintenance or repairs of cracks or settling imperfections greater than 2 inches deep on the cover shall be completed within 60 days of discovery.

3. Is there an imminent hazard to the integrity of the landfill cover?

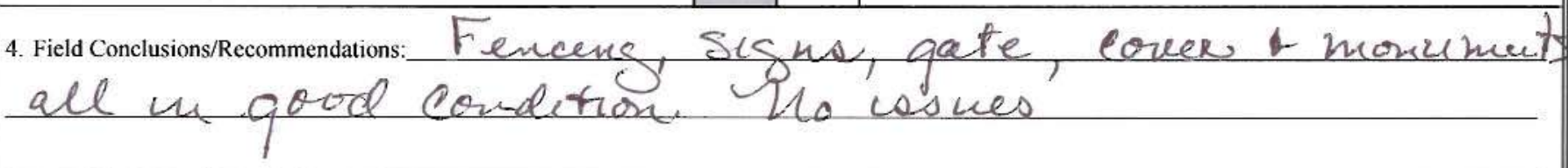

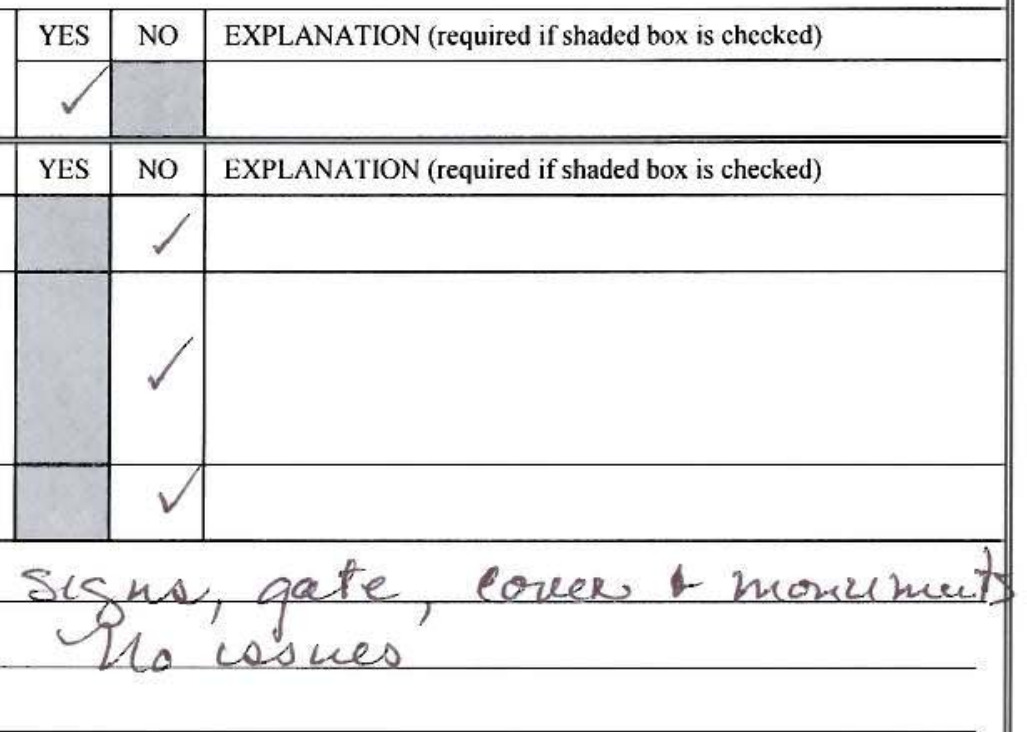



POST-CLOSURE INSPECTION CHECKLIST

\section{CAU 92, AREA 6 DECON POND FACILITY - CAS 06-05-02, DECONTAMINATION POND (RCRA)}

E. CERTIFICATION: I have conducted this inspection in accordance with the post-closure requirements as recorded on this checklist and attachments.

Chief Inspector's Signature;/s/: Rebecca King

Date: $2 / 12 / 13$

F. VERIFICATION: I have reviewed this checklist ad attachments and have verified that they are complete.

Signature: /s/: Reed Poderis

Date: $3 / 18 / 2013$

Printed Name: Thomas A. Thiele (or designee) 
POST-CLOSURE INSPECTION CHECKLIST

\section{CAU 92, AREA 6 DECON POND FACILITY - CAS 06-05-02, DECONTAMINATION POND (RCRA)}

Inspection Date:

$6 / 12 / 13$

If this inspection is for a rain event, date of event:

Date of Last Post-Closure Inspection:

Responsible Entity: NSTec Environmental Restoration, Nevada National Security Site, Mercury, Nevada

Responsible Facility Owner: Thomas A. Thiele, Project Manager, Industrial Sites, Environmental Restoration Project

Chief Inspector: Kebeeca

A. GENERAL INSTRUCTIONS

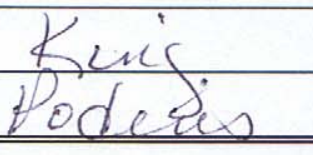

Hode

- The site inspection is a walking inspection of the entire site including the perimeter and sufficient and all features specifically described in this checklist.

- All documentation must be legible and clear. Complete all checklist items.

- If a shaded box is checked, add detailed comments to document the results of the site inspection. Information provided should be of sufficient detail to enable reconstruction of observations regarding field conditions. The completed checklist is part of the field record of the inspection.

- Field notes taken to assist in completion of this checklist will become part of the inspection record. No form is specified for field notes, and additional field notes are not required if the checklist and associated attachments adequately describe site conditions.

\begin{tabular}{|c|c|c|c|}
\hline B. PREPARATION (To be completed prior to the site visit) & YES & NO & EXPLANATION (required if shaded box is checked) \\
\hline \multicolumn{4}{|l|}{ 1. Were anomalies or trends detected on previous inspections? } \\
\hline \multicolumn{4}{|l|}{$\begin{array}{l}\text { 2. Were maintenance or repair activities performed since the last } \\
\text { inspection? }\end{array}$} \\
\hline $\begin{array}{l}\text { a. If yes, has repair resulted in a change from as-built } \\
\text { conditions? }\end{array}$ & & & NA \\
\hline $\begin{array}{l}\text { b. If yes (to } 2 \mathrm{a} \text { ), are revised as-built plans available that reflect } \\
\text { repair changes? }\end{array}$ & & & NA \\
\hline
\end{tabular}

C. SITE INSPECTION (To be completed during the site visit)

1. Adjacent Offsite Features:
a. Are there any new activities or offsite features that could
potentially affect the site?

2. Site Markers:

a. Is there damage to the gate or gate lock?

b. Is there damage to or a break in the fence?

c. Have any fenceposts been damaged or their anchoring weakened?

d. Are all use restriction signs legible?

e. How many damaged or missing use restriction signs need to be replaced?

f. How many use restriction signs are down or loose and need to be re-hung?

g. Do any Underground Radioactive Material Area signs need to be replaced or re-hung?

h. Is there damage to any of the subsidence survey markers?

i. Is there standing water within the fenced area?

j. Is there trash or other debris within the fenced area?

\begin{tabular}{|r|r|l||}
\hline YES & NO & EXPLANATION (required if shaded box is checked) \\
\hline & $\checkmark$ & \\
\hline YES & NO & EXPLANATION (required if shaded box is checked) \\
\hline & $\checkmark$ & \\
\hline & $\checkmark$ & \\
\hline$\checkmark$ & $\checkmark$ & \\
\hline & 0 & \\
\hline & 0 & \\
\hline & $\checkmark$ & \\
\hline & $\checkmark$ & \\
\hline & $\checkmark$ & \\
\hline & $\checkmark$ & \\
\hline
\end{tabular}




\section{POST-CLOSURE INSPECTION CHECKLIST}

\section{CAU 92, AREA 6 DECON POND FACILITY - CAS 06-05-02, DECONTAMINATION POND (RCRA)}

3. Waste Unit Cover:

a. Is there evidence of settling or cracking?

b. Is there evidence of erosion (wind or water)?

c. Is there evidence of human intrusion onto the site?

d. Is there evidence of large animal intrusion onto the site?

e. Is there evidence of animal burrowing?

f. Is there vegetation growing on the cover?

g. Is there standing water on the cover?

h. Are there any other issues not specifically described in this checklist?

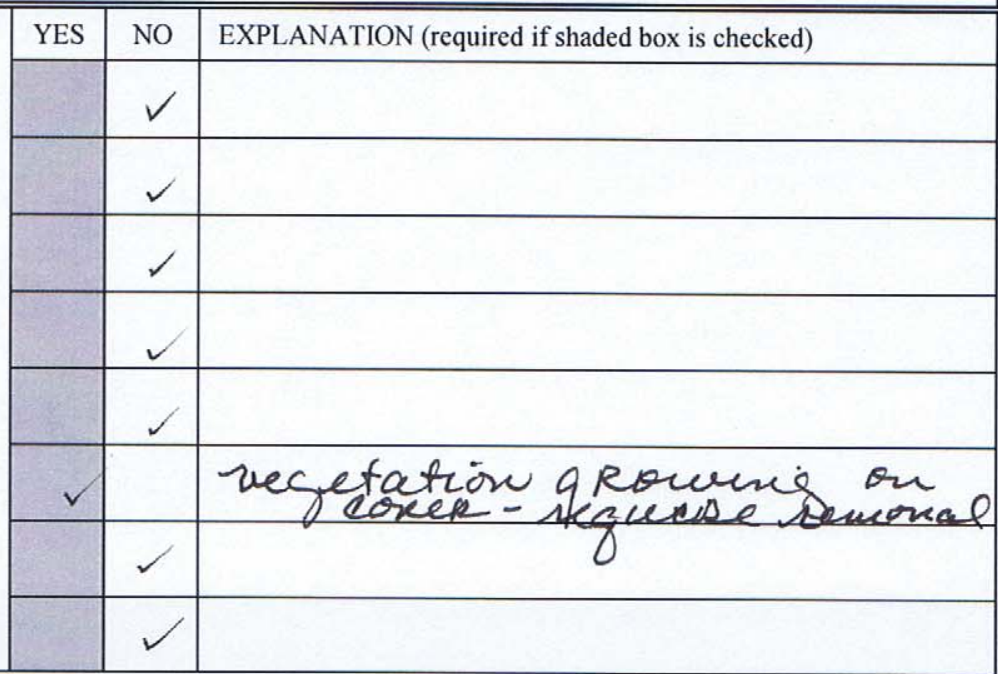

Photograph Instructions:

- The following photographs must be taken during each inspection:

- Four from the center of the unit, one in each compass direction (i.e., N, S, E, W)

- Four of the unit from outside the fence, one in each compass direction (i.e., N, S, E, W)

- Photographs should also be taken to document maintenance/repair needs, anomalous features, or new features (such as changes in adjacent area land use). These will be used to plan maintenance/repair activities and are not intended for use in the annual post-closure report.

- Photographs will be filed electronically.

4. Photograph Documentation:

a. Have all required photographs of the site been taken?

\section{FIELD CONCLUSIONS}

1. Is general housekeeping or minor repair (including cracks or settling less than 2 inches deep on the cover) required?

2. Are there deficiencies that require a remedy other than general housekeeping or minor repair? (For example, are there cracks greater than 2 inches deep on the cover?) Maintenance or repairs of cracks or settling imperfections greater than 2 inches deep on the cover shall be completed within 60 days of discovery.

3. Is there an imminent hazard to the integrity of the landfill cover?

\begin{tabular}{|c|c|c|}
\hline YES & NO & EXPLANATION (required if shaded box is checked) \\
\hline YES & NO & EXPLANATION (reauired if shaded box is checked) \\
\hline$\checkmark$ & & $\sec 2.4$ \\
\hline & $\sqrt{ }$ & \\
\hline & 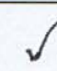 & \\
\hline
\end{tabular}

4. Field Conclusions/Recommendations: Negefation present on couer. Appliceting of herbicide recommended. Rest of the site lie good condetion. Fenceing, scgks, monn ments, gate all ue good condition.

E. CERTIFICATION: I have conducted this inspection in accordance with the post-closure requirements as recorded on this checklist and attachments.

Chief Inspector's Signature: /s/: Rebecca King

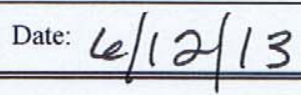




\begin{tabular}{|c|c|}
\hline \multicolumn{2}{|c|}{ POST-CLOSURE INSPECTION CHECKLIST } \\
\hline \multicolumn{2}{|c|}{ CAU 92, AREA 6 DECON POND FACILITY - CAS 06-05-02, DECONTAMINATION POND (RCRA) } \\
\hline \multicolumn{2}{|c|}{ F. VERIFICATION: I have reviewed this checklist and attachments and have verified that they are complete. } \\
\hline Signature: /s/: Reed Poderis & Date: $7 / 17 / 13$ \\
\hline
\end{tabular}


Inspection Requirement: Quarterly or Rain Event $>0.5$ inches in 24 hours

POST-CLOSURE INSPECTION CHECKLIST

\section{CAU 92, AREA 6 DECON POND FACILITY - CAS 06-05-02, DECONTAMINATION POND (RCRA)}

\begin{tabular}{|l|l|}
\hline Inspection Date: $9 / 03 / 13$ & Reason for Inspection: Precipitation Event \\
\hline If this inspection is for a rain event, date of event: $9 / 01 / 13$ & Quantity of Rainfall: $0.96 \quad$ inches \\
\hline Date of Last Post-Closure Inspection: 6/12/13 & Reason for Last Post-Closure Inspection: Quarterly Inspections \\
\hline
\end{tabular}

Responsible Entity: NSTec Environmental Restoration, Nevada National Security Site, Mercury, Nevada

Responsible Facility Owner: Thomas A. Thiele, Project Manager, Industrial Sites, Environmental Restoration Project

Chief Inspector: Brian Konrad

Assistant Inspector: N/A

Title: Environmental Waste Operations Coordinator

Title: N/A

\section{A. GENERAL INSTRUCTIONS}

- The site inspection is a walking inspection of the entire site including the perimeter and sufficient transects to be able to inspect the entire surface and all features specifically described in this checklist.

- All documentation must be legible and clear. Complete all checklist items.

- If a shaded box is checked, add detailed comments to document the results of the site inspection. Information provided should be of sufficient detail to enable reconstruction of observations regarding field conditions. The completed checklist is part of the field record of the inspection.

- Field notes taken to assist in completion of this checklist will become part of the inspection record. No form is specified for field notes, and additional field notes are not required if the checklist and associated attachments adequately describe site conditions.

\begin{tabular}{|l|l|l|l||}
\hline \hline B. PREPARATION (To be completed prior to the site visit) & YES & NO & EXPLANATION (required if shaded box is checked) \\
\hline 1. Were anomalies or trends detected on previous inspections? & $\mathbf{X}$ & & Vegetation on cover \\
\cline { 2 - 5 } $\begin{array}{l}\text { 2. Were maintenance or repair activities performed since the last } \\
\text { inspection? }\end{array}$ & $\mathbf{X}$ & & \multicolumn{2}{|l||}{ Completed on 7/9/13 } \\
\cline { 2 - 5 } $\begin{array}{c}\text { a. If yes, has repair resulted in a change from as-built } \\
\text { conditions? }\end{array}$ & $\mathbf{X}$ & NA & \\
\cline { 2 - 4 } $\begin{array}{l}\text { b. If yes (to 2a), are revised as-built plans available that reflect } \\
\text { repair changes? }\end{array}$ & & $\begin{array}{l}\text { NA } \\
\text { X }\end{array}$ & \\
\hline \hline
\end{tabular}

C. SITE INSPECTION (To be completed during the site visit)

1. Adjacent Offsite Features:
a. Are there any new activities or offsite features that could
potentially affect the site?

2. Site Markers:

a. Is there damage to the gate or gate lock?

b. Is there damage to or a break in the fence?

c. Have any fenceposts been damaged or their anchoring weakened?

d. Are all use restriction signs legible?

e. How many damaged or missing use restriction signs need to be replaced?

f. How many use restriction signs are down or loose and need to be re-hung?

g. Do any Underground Radioactive Material Area signs need to be replaced or re-hung?

h. Is there damage to any of the subsidence survey markers?

i. Is there standing water within the fenced area?

j. Is there trash or other debris within the fenced area?

\begin{tabular}{|l|l|l||}
\hline YES & NO & EXPLANATION (required if shaded box is checked) \\
\hline & $X$ & \\
\hline YES & NO & EXPLANATION (required if shaded box is checked) \\
\hline & $X$ & \\
\hline & $X$ & \\
\hline$X$ & & \\
\hline & 0 & \\
\hline & 0 & \\
\hline & $X$ & \\
\hline & $X$ & \\
\hline$X$ & & not on Covcr \\
\hline$X$ & & minimol dead weeds. \\
\hline
\end{tabular}


POST-CLOSURE INSPECTION CHECKLIST

\section{CAU 92, AREA 6 DECON POND FACILITY - CAS 06-05-02, DECONTAMINATION POND (RCRA)}

3. Waste Unit Cover:

a. Is there evidence of settling or cracking?

b. Is there evidence of erosion (wind or water)?

c. Is there evidence of human intrusion onto the site?

d. Is there evidence of large animal intrusion onto the site?

e. Is there evidence of animal burrowing?

f. Is there vegetation growing on the cover?

g. Is there standing water on the cover?

h. Are there any other issues not specifically described in this checklist?

\begin{tabular}{|c|c|l|l|}
\hline YES & NO & EXPLANATION (required if shaded box is checked) \\
\hline & $X$ & \\
& $X$ & \\
\hline & $X$ & \\
\hline & $X$ & \\
\hline & $X$ & \\
\hline$X$ & & alot of Shall ceqetridn \\
\hline & $X$ &
\end{tabular}

Photograph Instructions:

- The following photographs must be taken during each inspection:

- Four from the center of the unit, one in each compass direction (i.e., N, S, E, W)

- Four of the unit from outside the fence, one in each compass direction (i.e., N, S, E, W)

- Photographs should also be taken to document maintenance/repair needs, anomalous features, or new features (such as changes in adjacent area land use). These will be used to plan maintenance/repair activities and are not intended for use in the annual post-closure report.

- Photographs will be filed electronically.

4. Photograph Documentation:

a. Have all required photographs of the site been taken?

\section{FIELD CONCLUSIONS}

1. Is general housekeeping or minor repair (including cracks or settling less than 2 inches deep on the cover) required?

2. Are there deficiencies that require a remedy other than general housekeeping or minor repair? (For example, are there cracks greater than 2 inches deep on the cover?) Maintenance or repairs of cracks or settling imperfections greater than 2 inches deep on the cover shall be completed within 60 days of discovery.

3. Is there an imminent hazard to the integrity of the landfill cover?
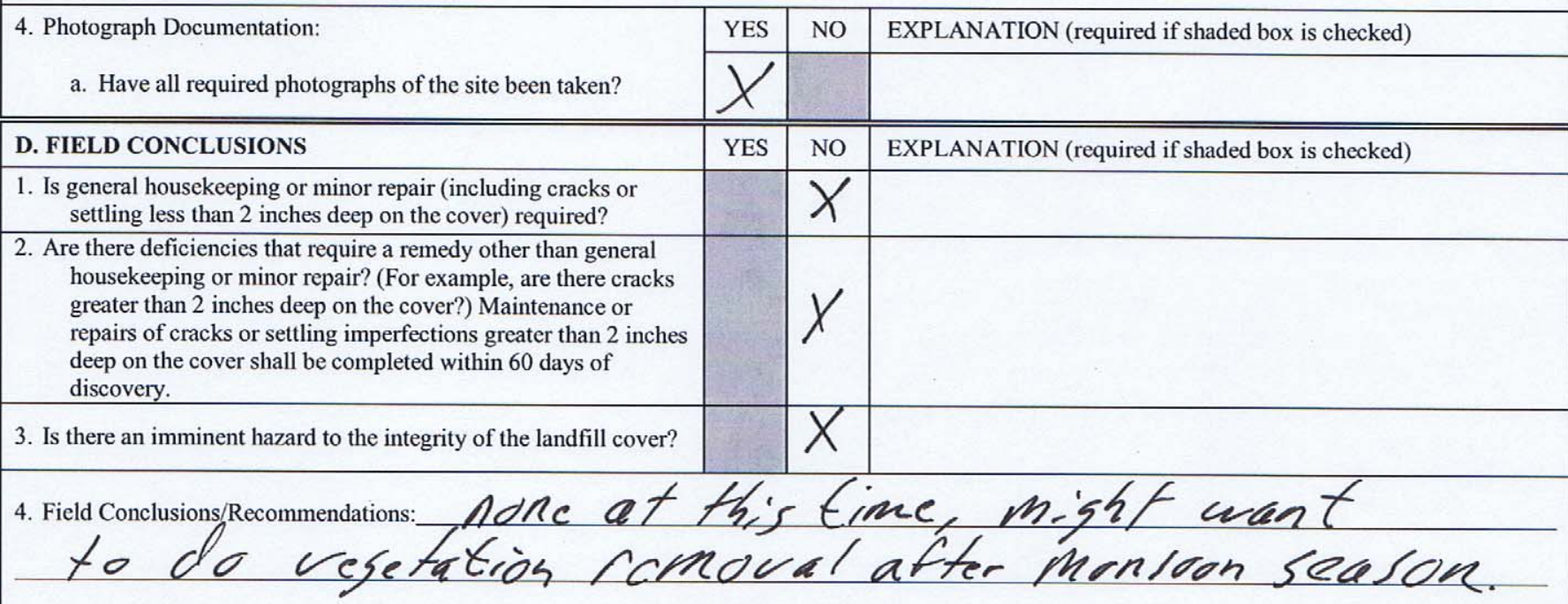

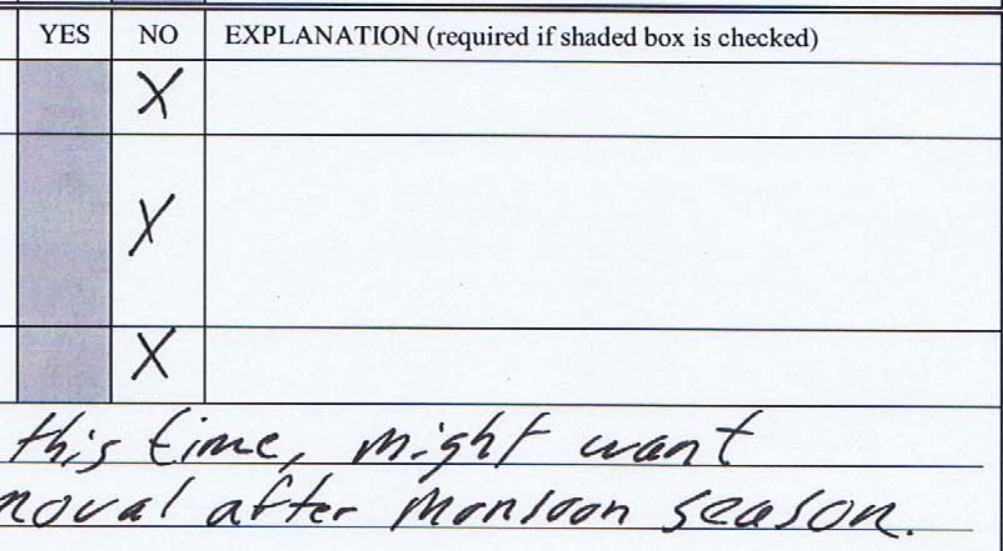

E. CERTIFICATION: I have conducted this inspection in accordance with the post-closure requirements as recorded on this checklist and attachments.

Chief Inspector's Signature: /s/: Brian Konrad

Date: 
POST-CLOSURE INSPECTION CHECKLIST

\section{CAU 92, AREA 6 DECON POND FACILITY - CAS 06-05-02, DECONTAMINATION POND (RCRA)}

F. VERIFICATION: I have reviewed this checklist and attachments and have verified that they are complete.

Signature: /s/: Reed Poderis

Date: $9-23-13$

Printed Name: Thomas A. Thiele (or designee) 
Inspection Requirement: Quarterly or Rain Event $>0.5$ inches in 24 hours

\section{POST-CLOSURE INSPECTION CHECKLIST}

\section{CAU 92, AREA 6 DECON POND FACILITY - CAS 06-05-02, DECONTAMINATION POND (RCRA)}

Inspection Date:

$9 / 18 / 13$

If this inspection is for a rain event, date of event:

Date of Last Post-Closure Inspection: $9 / 3 / 13$

Responsible Entity: NSTec Environmental Restoration, Nevada National Security Site, Mercury, Nevada

Responsible Facility Owner: Thomas A. Thiele, Project Manager, Industrial Sites, Environmental Restoration Project

Chief Inspector:

Assistant Inspector:

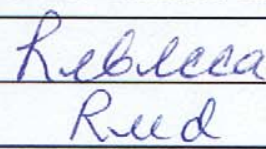

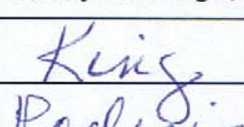

Poderio

\section{A. GENERAL INSTRUCTIONS}

- The site inspection is a walking inspection of the entire site including the perimeter and sufficient transects to be able to inspect the entire surface and all features specifically described in this checklist.

- All documentation must be legible and clear. Complete all checklist items.

- If a shaded box is checked, add detailed comments to document the results of the site inspection. Information provided should be of sufficient detail to enable reconstruction of observations regarding field conditions. The completed checklist is part of the field record of the inspection.

- Field notes taken to assist in completion of this checklist will become part of the inspection record. No form is specified for field notes, and additional field notes are not required if the checklist and associated attachments adequately describe site conditions.

B. PREPARATION (To be completed prior to the site visit)

1. Were anomalies or trends detected on previous inspections?

2. Were maintenance or repair activities performed since the last inspection?

a. If yes, has repair resulted in a change from as-built conditions?

b. If yes (to $2 \mathrm{a}$ ), are revised as-built plans available that reflect repair changes?

C. SITE INSPECTION (To be completed during the site visit)

1. Adjacent Offsite Features:

a. Are there any new activities or offsite features that could potentially affect the site?

2. Site Markers:

a. Is there damage to the gate or gate lock?

b. Is there damage to or a break in the fence?

c. Have any fenceposts been damaged or their anchoring weakened?

d. Are all use restriction signs legible?

e. How many damaged or missing use restriction signs need to be replaced?

f. How many use restriction signs are down or loose and need to be re-hung?

g. Do any Underground Radioactive Material Area signs need to be replaced or re-hung?

h. Is there damage to any of the subsidence survey markers?

i. Is there standing water within the fenced area?

j. Is there trash or other debris within the fenced area?

\begin{tabular}{|c|c|l|l|}
\hline YES & NO & EXPLANATION (required if shaded box is checked) \\
\hline & $\checkmark$ & \multicolumn{2}{|l|}{} \\
\hline$\checkmark$ & & helbicede cepplicece tion \\
\hline & $\checkmark$ & NA \\
& & NA
\end{tabular}

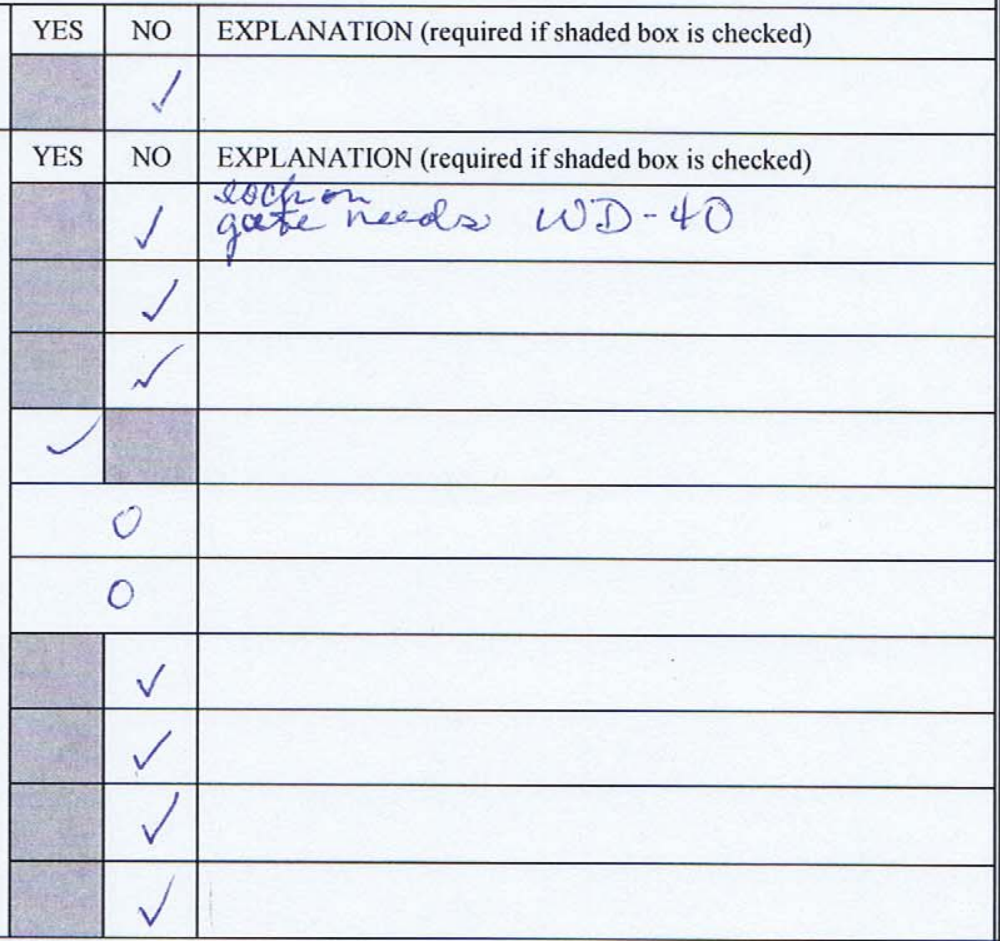




\section{POST-CLOSURE INSPECTION CHECKLIST}

\section{CAU 92, AREA 6 DECON POND FACILITY - CAS 06-05-02, DECONTAMINATION POND (RCRA)}

3. Waste Unit Cover:

a. Is there evidence of settling or cracking?

b. Is there evidence of erosion (wind or water)?

c. Is there evidence of human intrusion onto the site?

d. Is there evidence of large animal intrusion onto the site?

e. Is there evidence of animal burrowing?

f. Is there vegetation growing on the cover?

g. Is there standing water on the cover?

h. Are there any other issues not specifically described in this checklist?

Photograph Instructions:

\begin{tabular}{|c|c|c|}
\hline YES & NO & EXPLANATION (required if shaded box is checked) \\
\hline & $\checkmark$ & \\
\hline & $\sqrt{ }$ & \\
\hline & $\checkmark$ & \\
\hline & $\checkmark$ & \\
\hline & 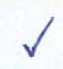 & \\
\hline & & $A K-9 \mid 18 / 12$ \\
\hline$\sqrt{ }$ & $\checkmark$ & $\begin{array}{l}\text { drad rusctation presant } \\
\text { flom heakicide gpples }\end{array}$ \\
\hline
\end{tabular}

- The following photographs must be taken during each inspection:

- Four from the center of the unit, one in each compass direction (i.e., N, S, E, W)

- Four of the unit from outside the fence, one in each compass direction (i.e., N, S, E, W)

- Photographs should also be taken to document maintenance/repair needs, anomalous features, or new features (such as changes in adjacent area land use). These will be used to plan maintenance/repair activities and are not intended for use in the annual post-closure report.

- Photographs will be filed electronically.

4. Photograph Documentation:

a. Have all required photographs of the site been taken?

\section{FIELD CONCLUSIONS}

1. Is general housekeeping or minor repair (including cracks or settling less than 2 inches deep on the cover) required?

2. Are there deficiencies that require a remedy other than general housekeeping or minor repair? (For example, are there cracks greater than 2 inches deep on the cover?) Maintenance or repairs of cracks or settling imperfections greater than 2 inches deep on the cover shall be completed within 60 days of discovery.

3. Is there an imminent hazard to the integrity of the landfill cover?

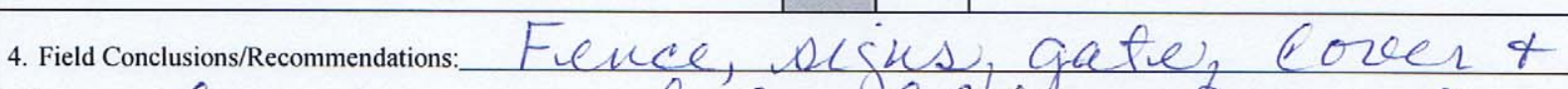

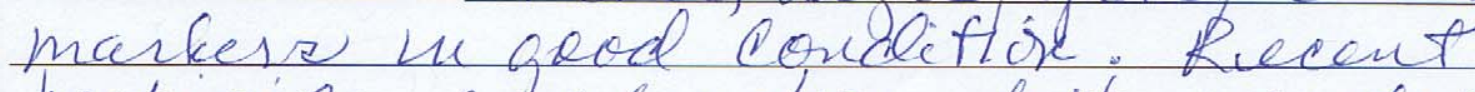

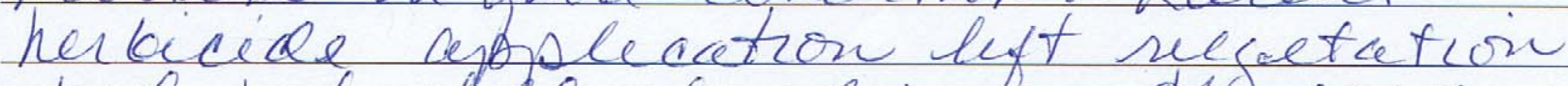

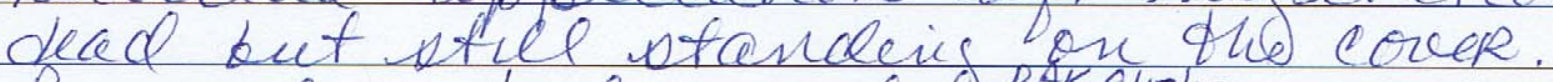

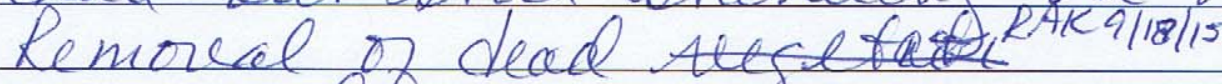
hes uniek?

\begin{tabular}{|r|r|r|l|}
\hline & YES & NO & EXPLANATION (required if shaded box is checked) \\
\hline & & \\
\hline & YES & NO & EXPLANATION (required if shaded box is checked) \\
\hline & & Re moue dead Megetation \\
\hline
\end{tabular}


Inspection Requirement: Quarterly or Rain Event $>0.5$ inches in 24 hours POST-CLOSURE INSPECTION CHECKLIST

\section{CAU 92, AREA 6 DECON POND FACILITY - CAS 06-05-02, DECONTAMINATION POND (RCRA)}

F. VERIFICATION: I have reviewed this checklist and attachments and have verified that they are complete.

Signature: /s/: Reed Poderis

Date: $9-24-13$

Printed Name: Thomas A. Thiele (or designee) 
RCRA Post-Closure Report

Revision: 0

Date: January 2014

Corrective ACTION Unit 110 InSPECTION CheCKLISTS 
RCRA Post-Closure Report

Revision: 0

Date: January 2014

\section{THIS PAGE INTENTIONALLY LEFT BLANK}




\section{POST-CLOSURE INSPECTION CHECKLIST}

CAU 110, AREA 3 WMD U-3AX/BL CRATER - CAS 03-23-04, U-3AXBL SUBSIDENCE CRATER

$\mathrm{m}$. Is there trash or other debris within the fenced area?

3. Waste Unit Cover:

a. Is there evidence of settling or cracking?

b. Is there evidence of erosion (wind or water)?

c. Is there evidence of human intrusion onto the site?

d. Is there evidence of large animal intrusion onto the site?

e. Is there evidence of animal burrowing?

f. Is there a change in the vegetation growing on the cover?

g. Are there any other issues not specifically described in this checklist?

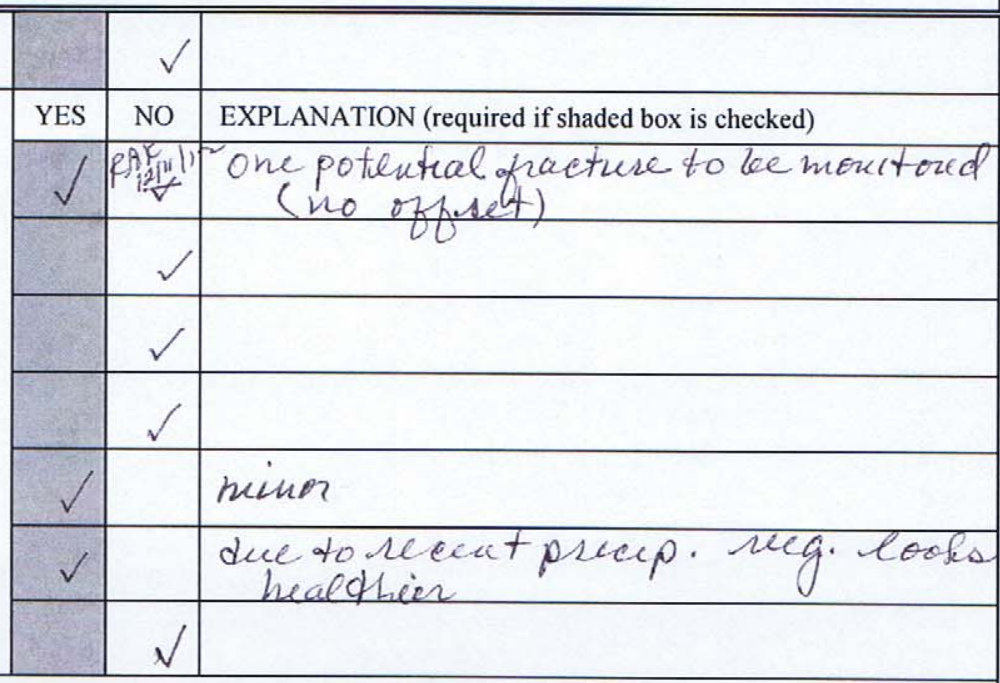

Photograph Instructions:

- The following photographs must be taken during each inspection:

- Four from the center of the unit, one in each compass direction (i.e., N, S, E, W)

- Four of the unit from outside the fence, one in each compass direction (i.e., N, S, E, W)

- Photographs should also be taken to document maintenance/repair needs, anomalous features, or new features (such as changes in adjacent area land use). These will be used to plan maintenance/repair activities and are not intended for use in the annual post-closure report.

- Photographs will be filed electronically.

4. Photograph Documentation:

a. Have all required photographs of the site been taken?

\section{FIELD CONCLUSIONS}

1. Is general housekeeping or minor repair (including cracks or settling imperfections less than 6 inches deep that extend less than 3 feet on the cover) required?

2 . Are there deficiencies that require a remedy other than general housekeeping or minor repair? (For example, are there cracks greater than 6 inches deep and 3 feet long on the cover?) Maintenance or repairs of cracks or settling imperfections greater than 6 inches deep and 3 feet long on the cover shall be completed within 60 days of discovery.

3. Is there an imminent hazard to the integrity of the landfill cover?

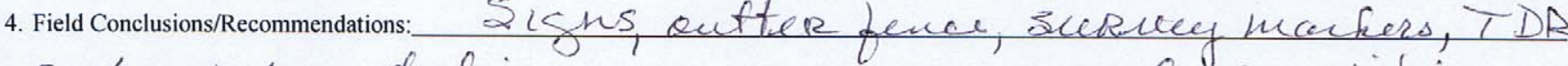

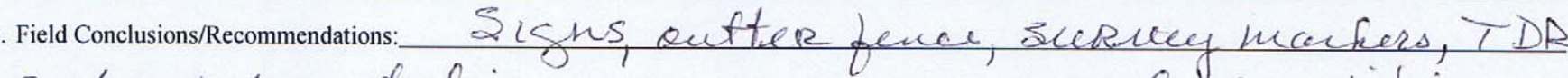

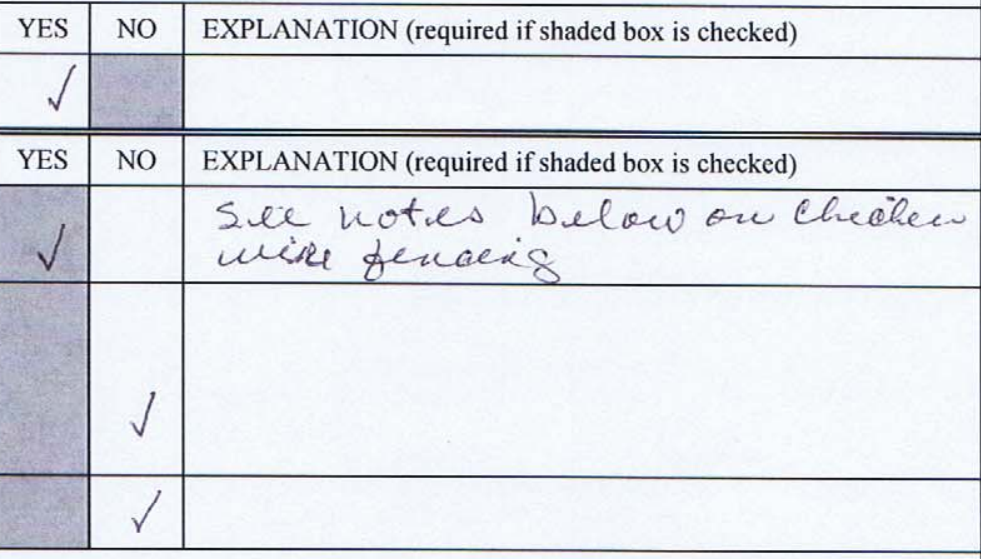

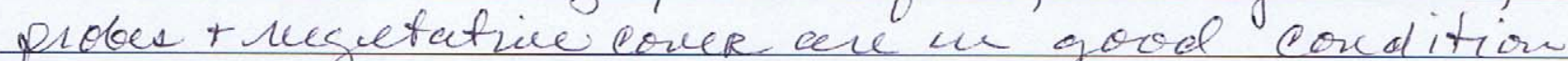

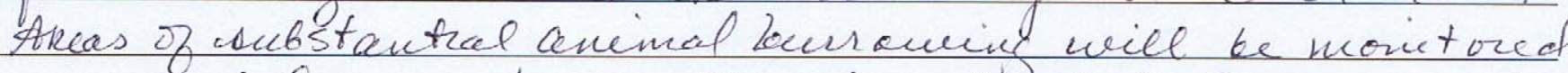

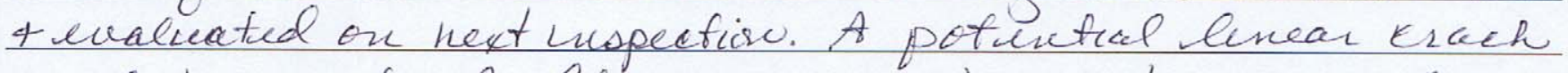

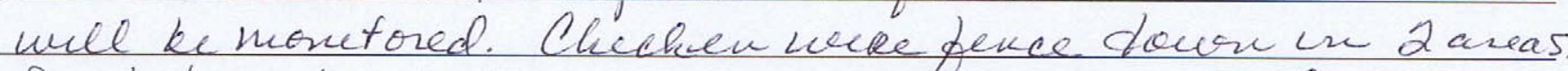

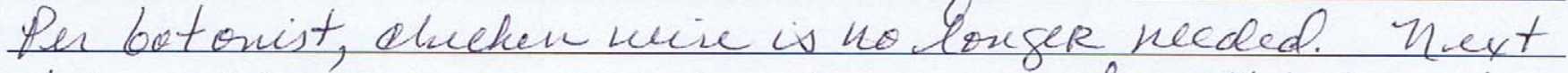

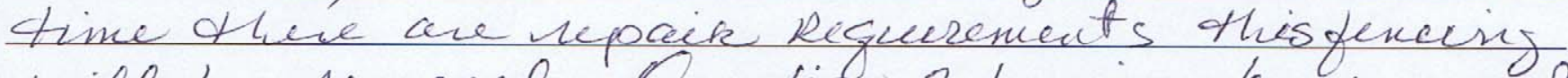

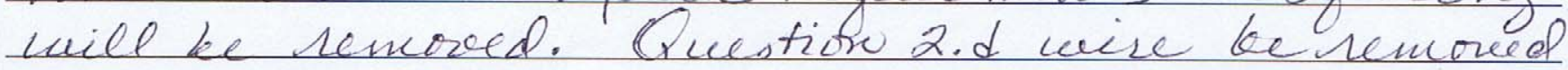

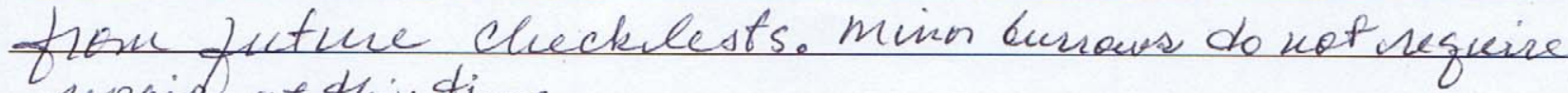
nepreid cet this time 


\section{POST-CLOSURE INSPECTION CHECKLIST}

\section{CAU 110, AREA 3 WMD U-3AX/BL CRATER - CAS 03-23-04, U-3AXBL SUBSIDENCE CRATER}

E. CERTIFICATION: I have conducted this inspection in accordance with the post-closure requirements as recorded on this checklist and attachments.

Chief Inspector's Signature: /s/: Rebecca King

Date: $12 / 12 / 12$

F. VERIFICATION: I have reviewed this checklist and attachments and have verified that they are complete.

Signature: /s/: Reed Poderis

Date:

$12 / 17 / 2$

Printed Name: Thomas A. Thiele (or designee) 


\section{POST-CLOSURE INSPECTION CHECKLIST}

\section{CAU 110, AREA 3 WMD U-3AX/BL CRATER - CAS 03-23-04, U-3AXBL SUBSIDENCE CRATER}

\begin{tabular}{ll|l} 
Inspection Date and Time: $3 / 12 / 13$ & Reason for Inspection: \\
Date of Last Post-Closure Inspection: $12 / 11 / 12$ & Reason for Last Post-Closure Inspection: \\
\hline Responsible Entity: NSTec Environmental Restoration, Nevada National Security Site Mercury, Nevada
\end{tabular}

Responsible Entity: NSTec Environmental Restoration, Nevada National Security Site, Mercury, Nevada

Responsible Facility Owner: Thomas A. Thiele, Project Manager, Industrial Sites, Environmental Restoration Project

Chief Inspector:

- The site inspection is a walking inspection of the entire site including the perimeter and sufficient transects to be able to inspect the entire surface and all features specifically described in this checklist.

- All documentation must be legible and clear. Complete all checklist items.

- If a shaded box is checked, add detailed comments to document the results of the site inspection. Information provided should be of sufficient detail to enable reconstruction of observations regarding field conditions. The completed checklist is part of the field record of the inspection.

- Field notes taken to assist in completion of this checklist will become part of the inspection record. No form is specified for field notes, and additional field notes are not required if the checklist and associated attachments adequately describe site conditions.

B. PREPARATION (To be completed prior to the site visit)

1. Were anomalies or trends detected on previous inspections?

2. Were maintenance or repair activities performed since the last inspection?

a. If yes, has repair resulted in a change from as-built conditions?

b. If yes (to $4 \mathrm{a}$ ), are revised as-built plans available that reflect repair changes?

\begin{tabular}{|l|r|l|l||}
\hline YES & NO & EXPLANATION (required if shaded box is checked) \\
\hline & $\sqrt{ }$ & \multicolumn{1}{|l||}{} \\
\hline & $\checkmark$ & \\
\hline & & NA & \\
\hline & & NA & \\
\hline
\end{tabular}

C. SITE INSPECTION (To be completed during the site visit)

1. Adjacent Offsite Features:

a. Are there any new activities or offsite features that could potentially affect the site?

2. Site Markers:

a. Is there damage to the gate or gate lock?

b. Is there damage to or a break in the fence?

c. Have any fenceposts been damaged or their anchoring weakened?

d. Are all use restriction signs legible?

e. Are any use restriction signs damaged or missing?

f. How many damaged or missing signs need to be replaced?

g. Are any use restriction signs down or loose?

h. How many down or loose signs need to be re-hung?

i. Do any Underground Radioactive Material Area signs need to be replaced or re-hung?

j. Is there damage to any of the subsidence survey markers?

k. Is there any evidence that TDR probes have been disturbed or the wires damaged?

1. Is there trash or other debris within the fenced area?

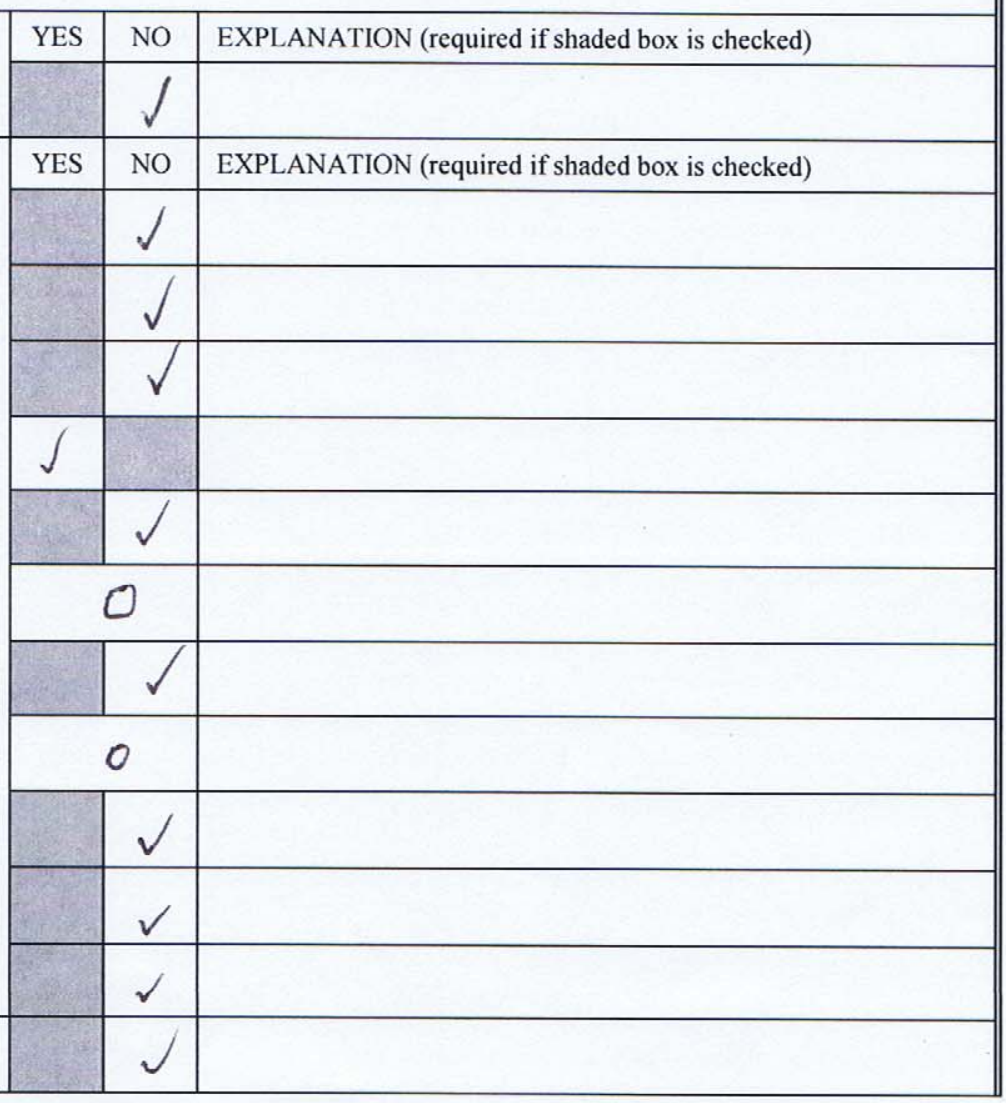

Page 1 of 3 


\section{POST-CLOSURE INSPECTION CHECKLIST}

CAU 110, AREA 3 WMD U-3AX/BL CRATER - CAS 03-23-04, U-3AXBL SUBSIDENCE CRATER

$\mathrm{m}$. Is there trash or other debris within the fenced area?

3. Waste Unit Cover:

a. Is there evidence of settling or cracking?

b. Is there evidence of erosion (wind or water)?

c. Is there evidence of human intrusion onto the site?

d. Is there evidence of large animal intrusion onto the site?

e. Is there evidence of animal burrowing?

f. Is there a change in the vegetation growing on the cover?

g. Are there any other issues not specifically described in this checklist?

Photograph Instructions:

- The following photographs must be taken during each inspection:

- Four from the center of the unit, one in each compass direction (i.e., N, S, E, W)

- Four of the unit from outside the fence, one in each compass direction (i.e., N, S, E, W)

- Photographs should also be taken to document maintenance/repair needs, anomalous features, or new features (such as changes in adjacent area land use). These will be used to plan maintenance/repair activities and are not intended for use in the annual post-closure report.

- Photographs will be filed electronically.

4. Photograph Documentation:

a. Have all required photographs of the site been taken?

\section{FIELD CONCLUSIONS}

1. Is general housekeeping or minor repair (including cracks or settling imperfections less than 6 inches deep that extend less than 3 feet on the cover) required?

2 . Are there deficiencies that require a remedy other than general housekeeping or minor repair? (For example, are there cracks greater than 6 inches deep and 3 feet long on the cover?) Maintenance or repairs of cracks or settling imperfections greater than 6 inches deep and 3 feet long on the cover shall be completed within 60 days of discovery.

3. Is there an imminent hazard to the integrity of the landfill cover?

4. Field Conclusions/Recommendations: An imal burvecuing at toe of Rover + Some on coner. Monitor kenvieg. kegetafioro survey to doter-

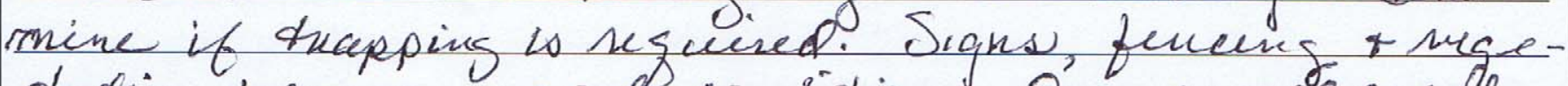
tatian + coner ungood condition? One omale encalh on rast cover has not changod riner lastiuspection. 710 actions necissary at dikis of ine. 
Inspection Requirements: Quarterly

\section{POST-CLOSURE INSPECTION CHECKLIST}

\section{CAU 110, AREA 3 WMD U-3AX/BL CRATER - CAS 03-23-04, U-3AXBL SUBSIDENCE CRATER}

E. CERTIFICATION: I have conducted this inspection in accordance with the post-closure requirements as recorded on this checklist and attachments.

Chief Inspector's Signature: /s/: Rebecca King

Date: $3 / 12113$

F. VERIFICATION: I have reviewed this checklist and attachments and have verified that they are complete.

Signature: /s/: Reed Poderis $\quad$ Date: $3 / 18 / 13$

Printed Name: Thomas A. Thiele (or designee) 


\section{POST-CLOSURE INSPECTION CHECKLIST}

\section{CAU 110, AREA 3 WMD U-3AX/BL CRATER - CAS 03-23-04, U-3AXBL SUBSIDENCE CRATER}

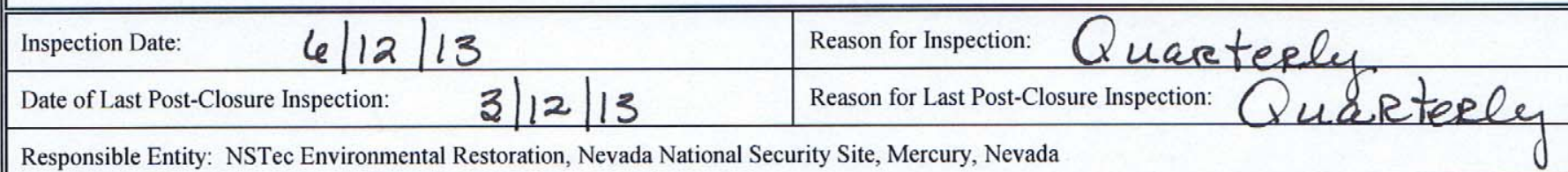

Responsible Facility Owner: Thomas A. Thiele, Project Manager, Industrial Sites, Environmental Restoration Project

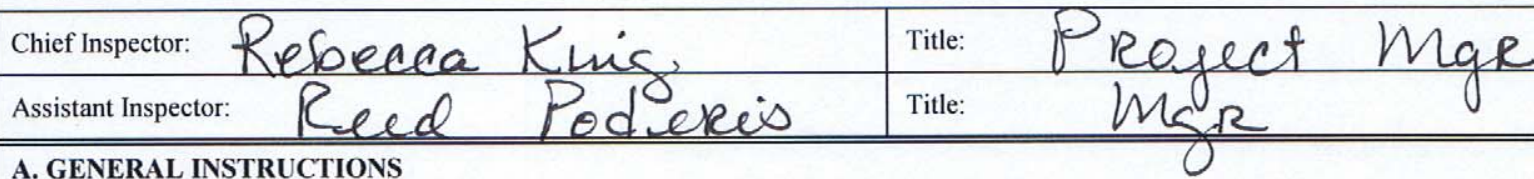

\section{A. GENERAL INSTRUCTIONS}

- The site inspection is a walking inspection of the entire site including the perimeter and sufficient transects to be able to inspect the entire surface and all features specifically described in this checklist.

- All documentation must be legible and clear. Complete all checklist items.

- If a shaded box is checked, add detailed comments to document the results of the site inspection. Information provided should be of sufficient detail to enable reconstruction of observations regarding field conditions. The completed checklist is part of the field record of the inspection.

- Field notes taken to assist in completion of this checklist will become part of the inspection record. No form is specified for field notes, and additional field notes are not required if the checklist and associated attachments adequately describe site conditions.

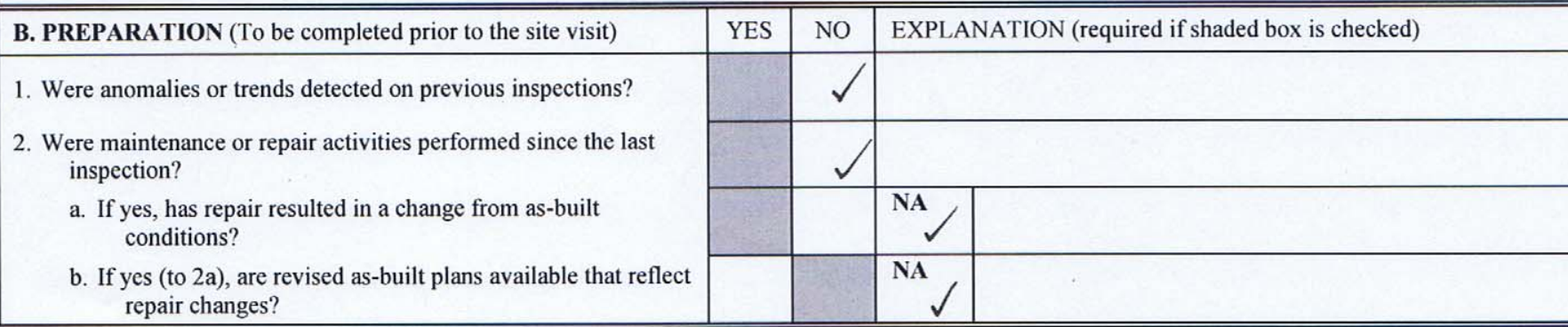

C. SITE INSPECTION (To be completed during the site visit)

1. Adjacent Offsite Features:

a. Are there any new activities or offsite features that could potentially affect the site?

\section{Site Markers:}

a. Is there damage to the gate or gate lock?

b. Is there damage to or a break in the fence?

c. Have any fenceposts been damaged or their anchoring weakened?

d. Are all use restriction signs legible?

e. How many damaged or missing use restriction signs need to be replaced?

f. How many use restriction signs are down or loose and need to be re-hung?

g. Do any Underground Radioactive Material Area signs need to be replaced or re-hung?

h. Is there damage to any of the subsidence survey markers?

i. Is there any evidence that TDR probes have been disturbed or the wires damaged?

j. Is there trash or other debris within the fenced area?

3. Waste Unit Cover:

a. Is there evidence of settling or cracking?

\begin{tabular}{|c|c|c|}
\hline YES & NO & EXPLANATION (required if shaded box is checked) \\
\hline & $\checkmark$ & \\
\hline YES & NO & EXPLANATION (required if shaded box is checked) \\
\hline$\checkmark$ & & damagee to henges \\
\hline & $\checkmark$ & \\
\hline & $\checkmark$ & \\
\hline$\checkmark$ & & $\begin{array}{l}\text { Howerer new labels appliced } \\
\text { to if faded sijus }\end{array}$ \\
\hline & $\underline{0}$ & \\
\hline & 0 & \\
\hline & $\checkmark$ & \\
\hline & $\checkmark$ & \\
\hline & $\checkmark$ & \\
\hline YES & NO & EXPLANATION (reauired if shaded box is checked) \\
\hline$\checkmark$ & & seurral areas on east \\
\hline
\end{tabular}

Page 1 of 3 
POST-CLOSURE INSPECTION CHECKLIST

\section{CAU 110, AREA 3 WMD U-3AX/BL CRATER - CAS 03-23-04, U-3AXBL SUBSIDENCE CRATER}

b. Is there evidence of erosion (wind or water)?

c. Is there evidence of human intrusion onto the site?

d. Is there evidence of large animal intrusion onto the site?

e. Is there evidence of animal burrowing?

f. Is there a change in the vegetation growing on the cover?

g. Are there any other issues not specifically described in this checklist?

\begin{tabular}{|l|l|l||}
\hline & $\checkmark$ & \\
\hline & $\checkmark$ & \\
\hline & $\checkmark$ & \\
\hline$\checkmark$ & & obsensed oreer most areas \\
\hline & $\checkmark$ & \\
\hline & $\checkmark$ & \\
\hline
\end{tabular}

\section{Photograph Instructions:}

- The following photographs must be taken during each inspection:

- Four from the center of the unit, one in each compass direction (i.e., N, S, E, W)

- Four of the unit from outside the fence, one in each compass direction (i.e., N, S, E, W)

- Photographs should also be taken to document maintenance/repair needs, anomalous features, or new features (such as changes in adjacent area land use). These will be used to plan maintenance/repair activities and are not intended for use in the annual post-closure report.

- Photographs will be filed electronically.

4. Photograph Documentation:

a. Have all required photographs of the site been taken?

\section{FIELD CONCLUSIONS}

1. Is general housekeeping or minor repair (including cracks or settling imperfections less than 6 inches deep that extend less than 3 feet on the cover) required?

2. Are there deficiencies that require a remedy other than general housekeeping or minor repair? (For example, are there cracks greater than 6 inches deep and 3 feet long on the cover?) Maintenance or repairs of cracks or settling imperfections greater than 6 inches deep and 3 feet long on the cover shall be completed within 60 days of discovery.

3. Is there an imminent hazard to the integrity of the landfill cover?

4. Field Conclusions/Recommendations: 2 igns un qood coudition, except 4 uith frealed teft ueere Repair dering inspection. Fences, TDR

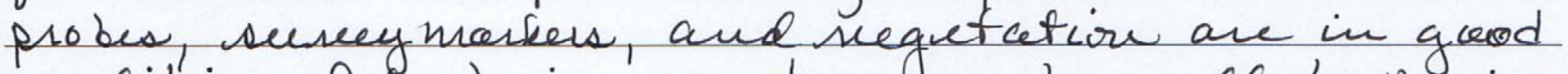

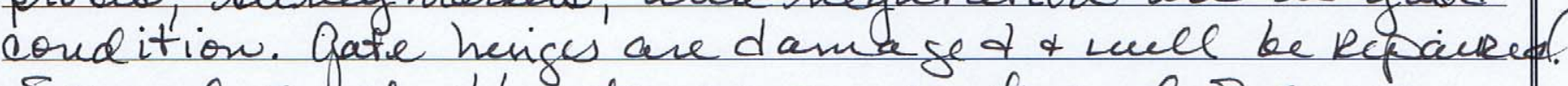

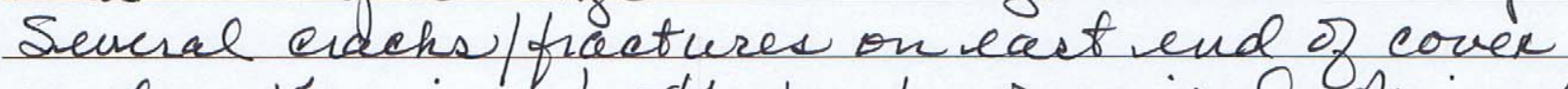
under Lsen in depth to be reparied. Animal

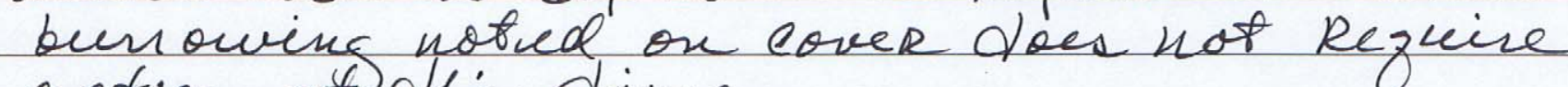
action at thies fine.

E. CERTIFICATION: I have conducted this inspection in accordance with the post-closure requirements as recorded on this checklist and attachments 


\begin{tabular}{|c|c|}
\hline \multicolumn{2}{|c|}{ POST-CLOSURE INSPECTION CHECKLIST } \\
\hline \multicolumn{2}{|c|}{ CAU 110, AREA 3 WMD U-3AX/BL CRATER - CAS 03-23-04, U-3AXBL SUBSIDENCE CRATER } \\
\hline F. VERIFICAYJON: I have reviewed this check & te \\
\hline Signature: /s/: Reed Poderis & Date: \\
\hline
\end{tabular}




\section{POST-CLOSURE INSPECTION CHECKLIST}

CAU 110, AREA 3 WMD U-3AX/BL CRATER - CAS 03-23-04, U-3AXBL SUBSIDENCE CRATER

\begin{tabular}{l|l} 
Inspection Date: & Reason for Inspection: \\
Date of Last Post-Closure Inspection: & Reason for Last Post-Closure Inspection:
\end{tabular}

Responsible Entity: NSTec Environmental Restoration, Nevada National Security Site, Mercury, Nevada

Responsible Facility Owner: Thomas A. Thiele, Project Manager, Industrial Sites, Environmental Restoration Project

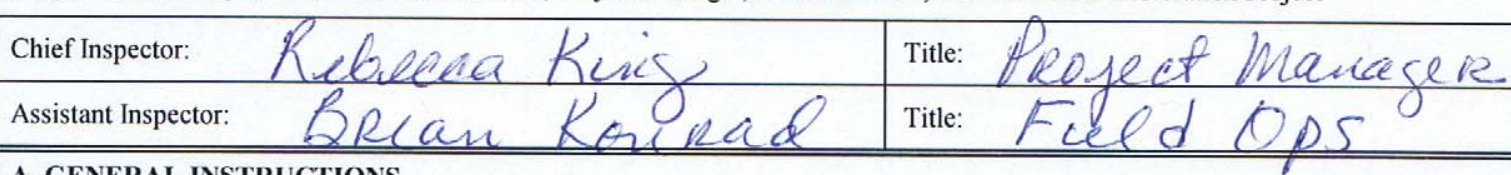

\section{A. GENERAL INSTRUCTIONS}

- The site inspection is a walking inspection of the entire site including the perimeter and sufficient transects to be able to inspect the entire surface and all features specifically described in this checklist.

- All documentation must be legible and clear. Complete all checklist items.

- If a shaded box is checked, add detailed comments to document the results of the site inspection. Information provided should be of sufficient detail to enable reconstruction of observations regarding field conditions. The completed checklist is part of the field record of the inspection.

- Field notes taken to assist in completion of this checklist will become part of the inspection record. No form is specified for field notes, and additional field notes are not required if the checklist and associated attachments adequately describe site conditions.

B. PREPARATION (To be completed prior to the site visit)

1. Were anomalies or trends detected on previous inspections?

2. Were maintenance or repair activities performed since the last inspection?

a. If yes, has repair resulted in a change from as-built conditions?

b. If yes (to 2a), are revised as-built plans available that reflect repair changes?

\begin{tabular}{|c|c|c|}
\hline YES & NO & EXPLANATION (required if shaded box is checked) \\
\hline$\checkmark$ & $\checkmark$ & $\begin{array}{l}\text { oructurel subsialener Repceir } \\
\text { gate Repar }\end{array}$ \\
\hline & & \begin{tabular}{l|l} 
NA & \\
\end{tabular} \\
\hline & & NA \\
\hline
\end{tabular}

\section{SITE INSPECTION (To be completed during the site visit)}

1. Adjacent Offsite Features:

a. Are there any new activities or offsite features that could potentially affect the site?

\section{Site Markers:}

a. Is there damage to the gate or gate lock?

b. Is there damage to or a break in the fence?

c. Have any fenceposts been damaged or their anchoring weakened?

d. Are all use restriction signs legible?

e. How many damaged or missing use restriction signs need to be replaced?

f. How many use restriction signs are down or loose and need to be re-hung?

g. Do any Underground Radioactive Material Area signs need to be replaced or re-hung?

h. Is there damage to any of the subsidence survey markers?

i. Is there any evidence that TDR probes have been disturbed or the wires damaged?

j. Is there trash or other debris within the fenced area?

3. Waste Unit Cover:

a. Is there evidence of settling or cracking?

\begin{tabular}{|c|c|c|}
\hline YES & NO & EXPLANATION (required if shaded box is checked) \\
\hline YES & NO & EXPLANATION (required if shaded box is checked) \\
\hline$\sqrt{ }$ & & gate was not loched. \\
\hline & $\checkmark$ & \\
\hline & & \\
\hline \multicolumn{2}{|c|}{0} & \\
\hline & $\sqrt{ }$ & \\
\hline & & \\
\hline & L & \\
\hline YES & NO & EXPLANATION (required if shaded box is checked) \\
\hline 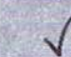 & & see section 4 \\
\hline
\end{tabular}




\section{POST-CLOSURE INSPECTION CHECKLIST}

\section{CAU 110, AREA 3 WMD U-3AX/BL CRATER - CAS 03-23-04, U-3AXBL SUBSIDENCE CRATER}

b. Is there evidence of erosion (wind or water)?

c. Is there evidence of human intrusion onto the site?

d. Is there evidence of large animal intrusion onto the site?

e. Is there evidence of animal burrowing?

f. Is there a change in the vegetation growing on the cover?

g. Are there any other issues not specifically described in this checklist?

\begin{tabular}{|c|c|c|}
\hline$\sqrt{ }$ & & sec section 4 \\
\hline & $\sqrt{ }$ & \\
\hline & $\checkmark$ & \\
\hline$\checkmark$ & & nuinor - no action Nequeirel \\
\hline & $\sqrt{ }$ & \\
\hline & $\sqrt{ }$ & \\
\hline
\end{tabular}

\section{Photograph Instructions:}

- The following photographs must be taken during each inspection:

- Four from the center of the unit, one in each compass direction (i.e., N, S, E, W)

- Four of the unit from outside the fence, one in each compass direction (i.e., N, S, E, W)

- Photographs should also be taken to document maintenance/repair needs, anomalous features, or new features (such as changes in adjacent area land use). These will be used to plan maintenance/repair activities and are not intended for use in the annual post-closure report.

- Photographs will be filed electronically.

4. Photograph Documentation:

a. Have all required photographs of the site been taken?

\section{FIELD CONCLUSIONS}

1. Is general housekeeping or minor repair (including cracks or settling imperfections less than 6 inches deep that extend less than 3 feet on the cover) required?

2. Are there deficiencies that require a remedy other than general housekeeping or minor repair? (For example, are there cracks greater than 6 inches deep and 3 feet long on the cover?) Maintenance or repairs of cracks or settling imperfections greater than 6 inches deep and 3 feet long on the cover shall be completed within 60 days of discovery.

3. Is there an imminent hazard to the integrity of the landfill cover?

4. Field Conclusions/Recommendations: Fence, Negus, TDA Proloos, ard survy marlews and hetation all id cood condefion. Nuvo areder D) Dllbsidence That meet ereteria to notipy NDEP bud kepreir. ERosion pills on aputh olope Do poxer to vepair.

\begin{tabular}{|c|c|c|}
\hline YES & NO & EXPLANATION (required if shaded box is checked) \\
\hline YES & NO & EXPLANATION (required if shaded box is checked) \\
\hline$\sqrt{ }$ & & erosion Reles \\
\hline$\sqrt{ }$ & & $2 \sec \theta$ sueleweer \\
\hline & & \\
\hline
\end{tabular}


Inspection Requirements: Quarterly

\section{POST-CLOSURE INSPECTION CHECKLIST}

CAU 110, AREA 3 WMD U-3AX/BL CRATER - CAS 03-23-04, U-3AXBL SUBSIDENCE CRATER

F. VERIFICATION: I have reviewed this checklist and attachments and have verified that they are complete.

Signature: /s/: Reed Poderis

Date: $9 / 24 / 13$

Printed Name: Thomas A. Thiele (or designee) 
RCRA Post-Closure Report

Revision: 0

Date: January 2014

Corrective Action Unit 111 InsPection CheCKLists 
RCRA Post-Closure Report

Revision: 0

Date: January 2014

\section{THIS PAGE INTENTIONALLY LEFT BLANK}




\section{POST-CLOSURE INSPECTION CHECKLIST}

\section{CAU 111, AREA 5 WMD RETIRED MIXED WASTE PITS - CAS 05-21-01, MIXED WASTE PITS}

\begin{tabular}{|c|c|c|}
\hline Inspection Date and Time: $\quad 1 \theta / 8 / 12$ & IOan & subsid.ence \\
\hline If this inspection is for a rain event, date of even & & Quantity of Rainfall: \\
\hline Date of Last Post-Closure Inspection: $9 / 1$ & & Reason for Last Post-Closure Inspection: \\
\hline
\end{tabular}

Responsible Facility Owner: Thomas A. Thiele, Project Manager, Industrial Sites, Environmental Restoration Project

Chief Inspector:

Assistant Inspector

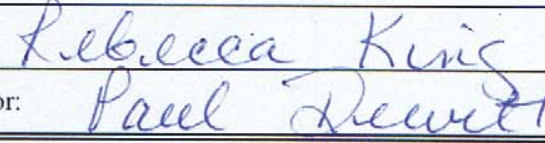

Title: Fised

Suplirecoor

\section{A. GENERAL INSTRUCTIONS}

- The site inspection is a walking inspection of the entire site including the perimeter and sufficient transects to be able to inspect the entire surface and all features specifically described in this checklist. Complete this checklist during the site inspection.

- All documentation must be legible and clear. Complete all checklist items.

- If a shaded box is checked, add detailed comments to document the results of the site inspection. Information provided should be of sufficient detail to enable reconstruction of observations regarding field conditions. The completed checklist is part of the field record of the inspection.

- Field notes taken to assist in completion of this checklist will become part of the inspection record. No form is specified for field notes, and additional field notes are not required if the checklist and associated attachments adequately describe site conditions.

B. PREPARATION (To be completed prior to the site visit)

1. Were anomalies or trends detected on previous inspections?

2. Were maintenance or repair activities performed since the last inspection?

a. If yes, has repair resulted in a change from as-built conditions?

b. If yes (to $4 a$ ), are revised as-built plans available that reflect repair changes?

\begin{tabular}{|c|c|c|c|}
\hline YES & NO & \multicolumn{2}{|c|}{ EXPLANATION (required if shaded box is checked) } \\
\hline$\gamma$ & & \multicolumn{2}{|c|}{ erosion repairs } \\
\hline & $\checkmark$ & $\stackrel{\mathrm{NA}}{\mathrm{N}}$ & RAK 10/8/12 \\
\hline & & $\stackrel{\mathrm{NA}}{\checkmark}$ & \\
\hline
\end{tabular}

C. SITE INSPECTION (To be completed during the site visit)

1. Adjacent Offsite Features:

a. Are there any new activities or offsite features that could potentially affect the site?

2. Site Markers:

a. Are all use restriction signs legible?

b. Are any use restriction signs damaged or missing?

c. How many damaged or missing signs need to be replaced?

d. Are any use restriction signs down or loose?

e. How many down or loose signs need to be re-hung?

f. Is there damage to any of the monuments?

3. Waste Unit Covers:

a. Is there evidence of settling or cracking?

b. Is there evidence of erosion (wind or water)?

c. Is there evidence of human intrusion onto the site?

d. Is there evidence of large animal intrusion onto the site?

\begin{tabular}{|c|c|c|}
\hline YES & NO & EXPLANATION (required if shaded box is checked) \\
\hline YES & NO & EXPLANATION (required if shaded box is checked) \\
\hline & $\checkmark$ & \\
\hline & 0 & \\
\hline & $\checkmark$ & \\
\hline & 0 & \\
\hline & $\checkmark$ & \\
\hline YES & NO & EXPLANATION (required if shaded box is checked) \\
\hline 1 & & $\begin{array}{l}4 \text { areas of subscdence on } \\
\text { west poreer }\end{array}$ \\
\hline & $\checkmark$ & \\
\hline & $\checkmark$ & \\
\hline & $\checkmark$ & \\
\hline
\end{tabular}

Page 1 of 2 


\section{POST-CLOSURE INSPECTION CHECKLIST}

\section{CAU 111, AREA 5 WMD RETIRED MIXED WASTE PITS - CAS 05-21-01, MIXED WASTE PITS}

e. Is there evidence of animal burrowing?

f. Is there a change in the vegetation growing on the cover?

g. Is there trash or debris on the cover?

h. Are there any other issues not specifically described in this checklist?

Photograph Instructions:

- Standard photographs must be taken during each inspection.

- Photographs should also be taken to document maintenance/repair needs, anomalous features, or new features (such as changes in adjacent area land use). These will be used to plan maintenance/repair activities and are not intended for use in the annual post-closure report.

- Photographs will be filed electronically.

4. Photograph Documentation:

a. Have all required photographs of the site been taken?

\section{FIELD CONCLUSIONS}

1. Is general housekeeping or minor repair (including cracks or settling imperfections less than 15 centimeters deep that extend less than 1 meter on the cover) required?

2. Are there deficiencies that require a remedy other than general housekeeping or minor repair? (For example, are there cracks greater than 15 centimeters deep and 1 meter long on the cover?) Maintenance or repairs of cracks or settling imperfections greater than 15 centimeters deep and 1 meter long on the cover shall be completed within 60 days of discovery. Damaged or missing UR warning signs will be repaired or replaced within 60 days of discovery.

3. Is there an imminent hazard to the integrity of the landfill cover?

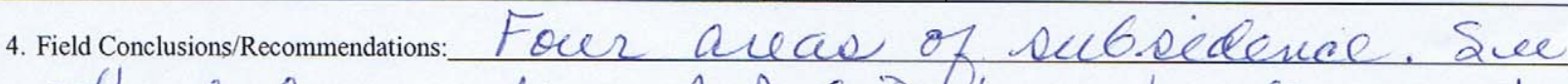
attached map. Areas A, B, C+D have fractures > 1 metrer mlength with $>15 \mathrm{~cm}$ depth m someareas. $A+B$ are approximately isft by $40 \mathrm{ft}$. (t) Dere approximately) 15t by $20 \mathrm{f}+$ with holes of rearejur depths. Arees

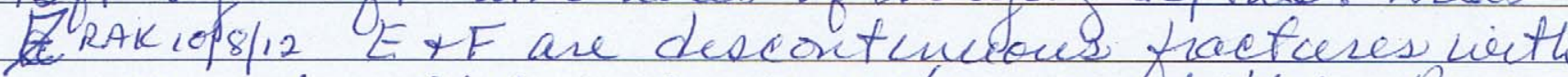

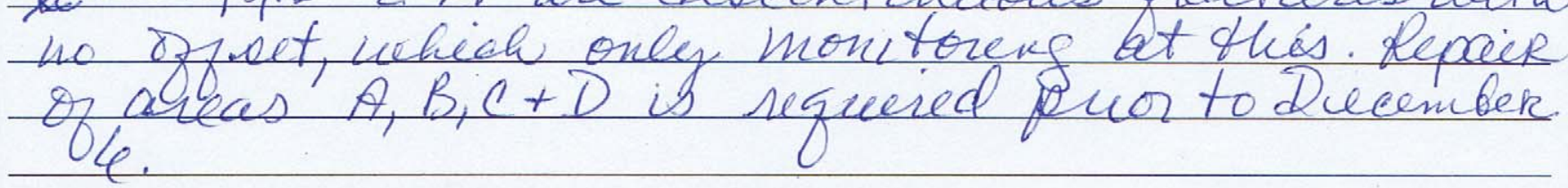

E. CERTIFICATION: I have conducted this inspection in accordance with the post-closure requirements as recorded on this checklist and attachments.

Chief Inspector's Signature: /S/: Rebecca King

F. VERIFICATION: I have reviewed this checklist and attachments and have verified that they are complete.

Signature: /s/: Reed Poderis

Date: $10 / 8 / 12$

Date: $10 / 18 / 12$

Printed Name: Thomas A. Thiele (or designee) 


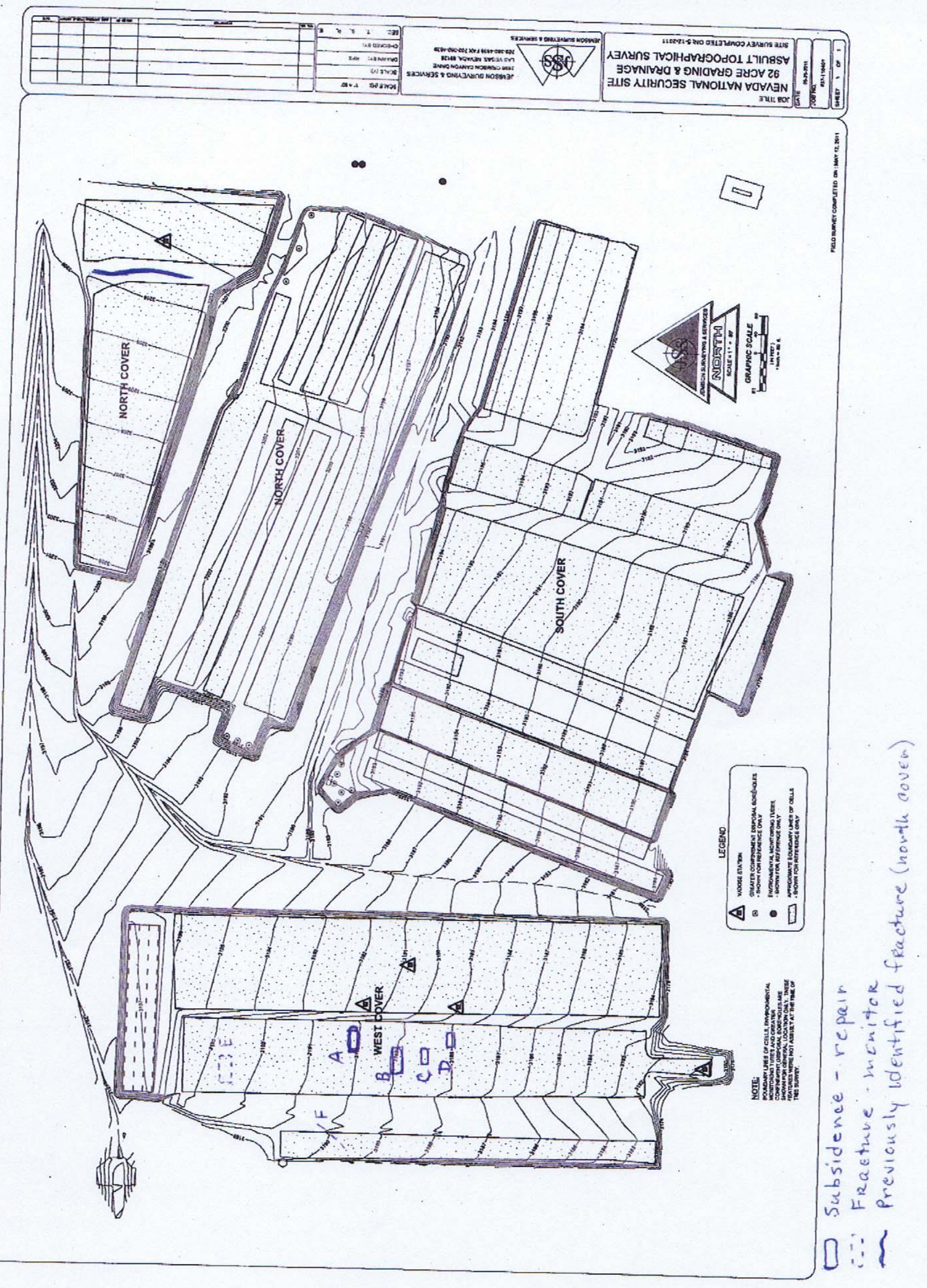




\section{POST-CLOSURE INSPECTION CHECKLIST}

\section{CAU 111, AREA 5 WMD RETIRED MIXED WASTE PITS - CAS 05-21-01, MIXED WASTE PITS}

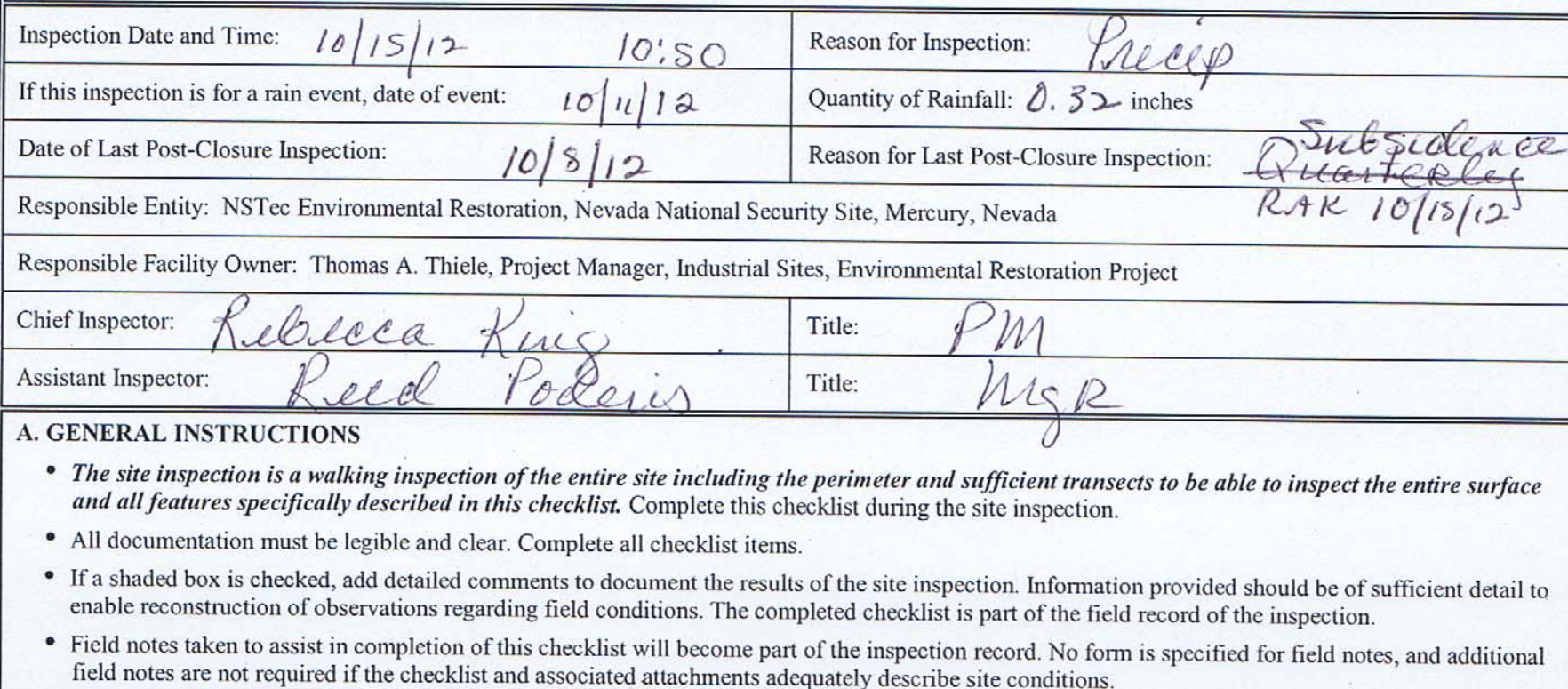

B. PREPARATION (To be completed prior to the site visit)

1. Were anomalies or trends detected on previous inspections?

2. Were maintenance or repair activities performed since the last inspection?

a. If yes, has repair resulted in a change from as-built conditions?

b. If yes (to $4 a$ ), are revised as-built plans available that reflect repair changes?

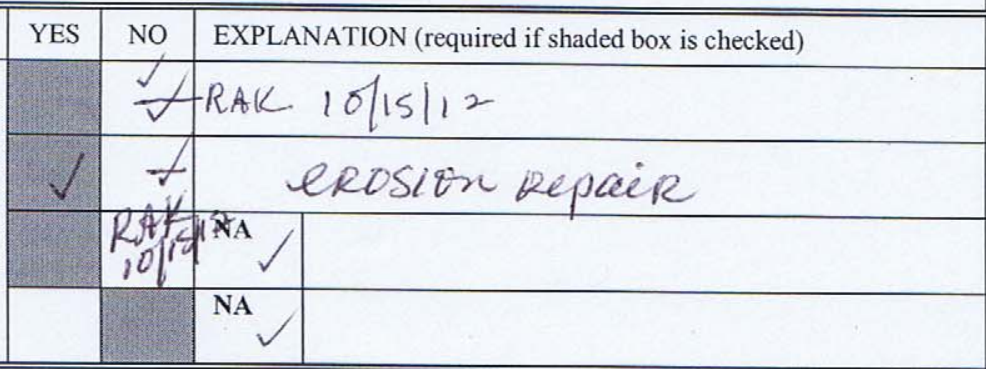

C. SITE INSPECTION (To be completed during the site visit)

1. Adjacent Offsite Features:

a. Are there any new activities or offsite features that could potentially affect the site?

2. Site Markers:

a. Are all use restriction signs legible?

b. Are any use restriction signs damaged or missing?

c. How many damaged or missing signs need to be replaced?

d. Are any use restriction signs down or loose?

e. How many down or loose signs need to be re-hung?

f. Is there damage to any of the monuments?

3. Waste Unit Covers:

a. Is there evidence of settling or cracking?

b. Is there evidence of erosion (wind or water)?

c. Is there evidence of human intrusion onto the site?

d. Is there evidence of large animal intrusion onto the site?

\begin{tabular}{|c|c|c|}
\hline YES & NO & EXPLANATION (required if shaded box is checked) \\
\hline & $\checkmark$ & \\
\hline YES & NO & EXPLANATION (required if shaded box is checked) \\
\hline & $J$ & \\
\hline & & \\
\hline & $\sqrt{ }$ & \\
\hline & 0 & \\
\hline & $\checkmark$ & \\
\hline YES & NO & EXPLANATION (required if shaded box is checked) \\
\hline 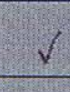 & & $\begin{array}{l}\text { Identifid on } 10 / 8 / 12 \text { chablest } \\
\text { andel } 9 / 13 / 12 \text { diecklest }\end{array}$ \\
\hline V & & mosion kied on west and \\
\hline & $\sqrt{ }$ & \\
\hline & $\sqrt{ }$ & \\
\hline
\end{tabular}




\section{POST-CLOSURE INSPECTION CHECKLIST}

\section{CAU 111, AREA 5 WMD RETIRED MIXED WASTE PITS - CAS 05-21-01, MIXED WASTE PITS}

e. Is there evidence of animal burrowing?

f. Is there a change in the vegetation growing on the cover?

g. Is there trash or debris on the cover?

h. Are there any other issues not specifically described in this checklist?

Photograph Instructions:

- Standard photographs must be taken during each inspection.

- Photographs should also be taken to document maintenance/repair needs, anomalous features, or new features (such as changes in adjacent area land use). These will be used to plan maintenance/repair activities and are not intended for use in the annual post-closure report.

- Photographs will be filed electronically.

4. Photograph Documentation:

a. Have all required photographs of the site been taken?

\section{FIELD CONCLUSIONS}

1. Is general housekeeping or minor repair (including cracks or settling imperfections less than 15 centimeters deep that extend less than 1 meter on the cover) required?

2. Are there deficiencies that require a remedy other than general housekeeping or minor repair? (For example, are there cracks greater than 15 centimeters deep and 1 meter long on the cover?) Maintenance or repairs of cracks or settling imperfections greater than 15 centimeters deep and 1 meter long on the cover shall be completed within 60 days of discovery. Damaged or missing UR warning signs will be repaired or replaced within 60 days of discovery.

3. Is there an imminent hazard to the integrity of the landfill cover?

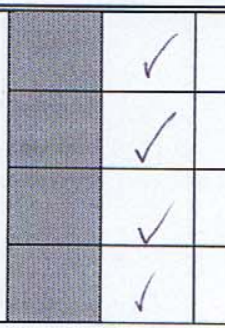
S 


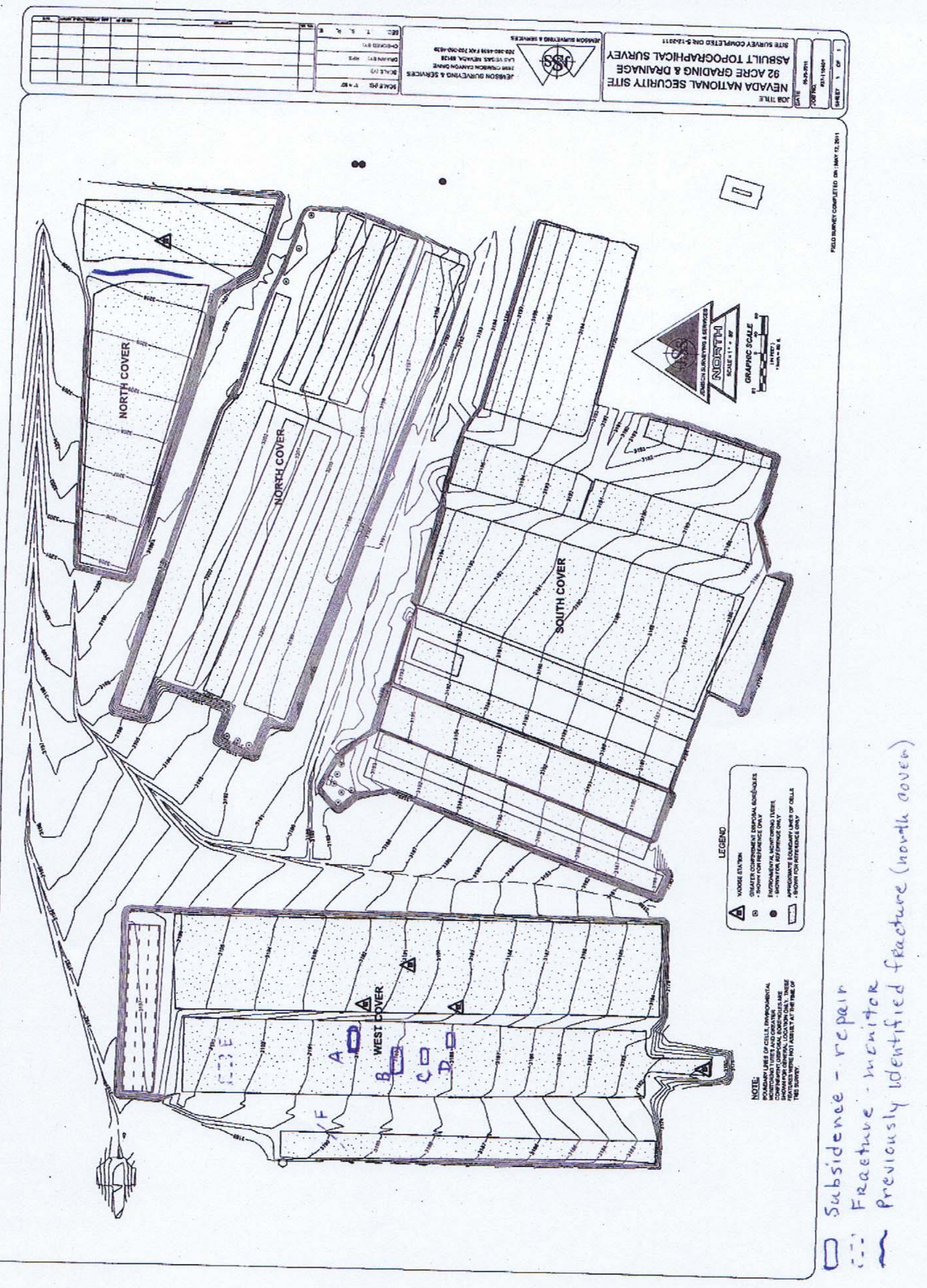


Inspection Requirement: Quarterly or Rain Event $>1.0$ inch in 24 hours

\section{POST-CLOSURE INSPECTION CHECKLIST}

\section{CAU 111, AREA 5 WMD RETIRED MIXED WASTE PITS - CAS 05-21-01, MIXED WASTE PITS}

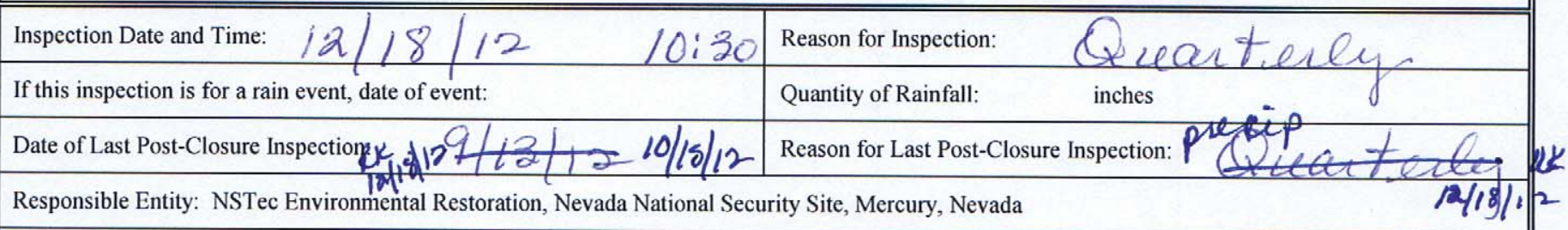

Responsible Facility Owner: Thomas A. Thiele, Project Manager, Industrial Sites, Environmental Restoration Project

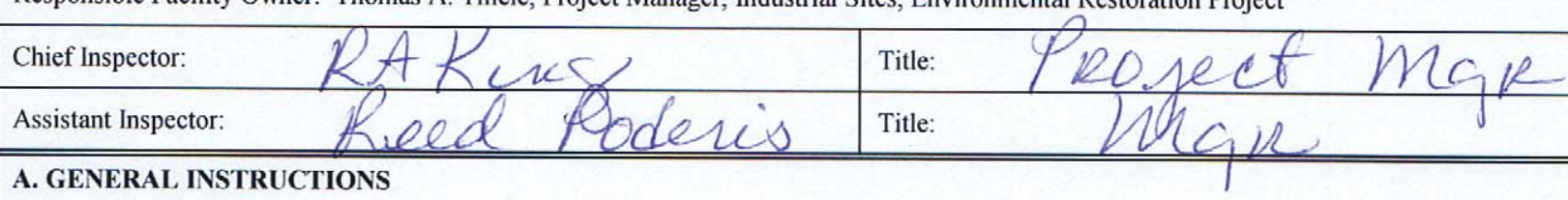

- The site inspection is a walking inspection of the entire site including the perimeter and sufficient transects to be able to inspect the entire surface and all features specifically described in this checklist. Complete this checklist during the site inspection.

- All documentation must be legible and clear. Complete all checklist items.

- If a shaded box is checked, add detailed comments to document the results of the site inspection. Information provided should be of sufficient detail to enable reconstruction of observations regarding field conditions. The completed checklist is part of the field record of the inspection.

- Field notes taken to assist in completion of this checklist will become part of the inspection record. No form is specified for field notes, and additional field notes are not required if the checklist and associated attachments adequately describe site conditions.

B. PREPARATION (To be completed prior to the site visit)

1. Were anomalies or trends detected on previous inspections?

2. Were maintenance or repair activities performed since the last inspection?

a. If yes, has repair resulted in a change from as-built conditions?

b. If yes (to $4 a$ ), are revised as-built plans available that reflect repair changes?

\begin{tabular}{|c|c|c|}
\hline YES & NO & EXPLANATION (required if shaded box is checked) \\
\hline & & 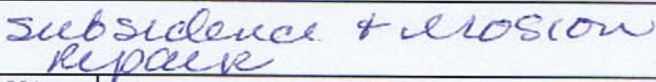 \\
\hline & & NA \\
\hline & & NA \\
\hline
\end{tabular}

C. SITE INSPECTION (To be completed during the site visit)

1. Adjacent Offsite Features:

a. Are there any new activities or offsite features that could potentially affect the site?

2. Site Markers:

a. Are all use restriction signs legible?

b. Are any use restriction signs damaged or missing?

c. How many damaged or missing signs need to be replaced?

d. Are any use restriction signs down or loose?

e. How many down or loose signs need to be re-hung?

f. Is there damage to any of the monuments?

3. Waste Unit Covers:

a. Is there evidence of settling or cracking?

b. Is there evidence of erosion (wind or water)?

c. Is there evidence of human intrusion onto the site?

d. Is there evidence of large animal intrusion onto the site?

\begin{tabular}{|c|c|c|}
\hline YES & NO & EXPLANATION (required if shaded box is checked) \\
\hline YES & NO & EXPLANATION (required if shaded box is checked) \\
\hline & & \\
\hline & 0 & \\
\hline & 0 & \\
\hline YES & NO & EXPLANATION (required if shaded box is checked) \\
\hline & & \\
\hline & 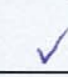 & \\
\hline & $V$ & \\
\hline & & \\
\hline
\end{tabular}




\section{POST-CLOSURE INSPECTION CHECKLIST}

\section{CAU 111, AREA 5 WMD RETIRED MIXED WASTE PITS - CAS 05-21-01, MIXED WASTE PITS}

e. Is there evidence of animal burrowing?

$\mathrm{f}$. Is there a change in the vegetation growing on the cover?

g. Is there trash or debris on the cover?

h. Are there any other issues not specifically described in this checklist?

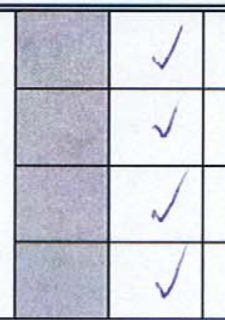

Photograph Instructions:

- Standard photographs must be taken during each inspection.

- Photographs should also be taken to document maintenance/repair needs, anomalous features, or new features (such as changes in adjacent area land use). These will be used to plan maintenance/repair activities and are not intended for use in the annual post-closure report.

- Photographs will be filed electronically.

4. Photograph Documentation:

a. Have all required photographs of the site been taken?

\section{FIELD CONCLUSIONS}

1. Is general housekeeping or minor repair (including cracks or settling imperfections less than 15 centimeters deep that extend less than 1 meter on the cover) required?

2. Are there deficiencies that require a remedy other than general housekeeping or minor repair? (For example, are there cracks greater than 15 centimeters deep and 1 meter long on the cover?) Maintenance or repairs of cracks or settling imperfections greater than 15 centimeters deep and 1 meter long on the cover shall be completed within 60 days of discovery. Damaged or missing UR warning signs will be repaired or replaced within 60 days of discovery.

3. Is there an imminent hazard to the integrity of the landfill cover?

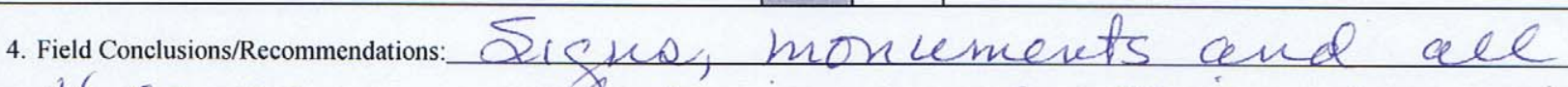

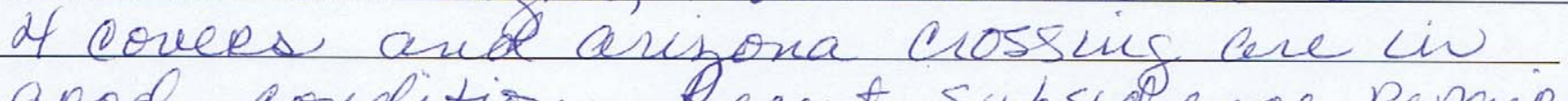

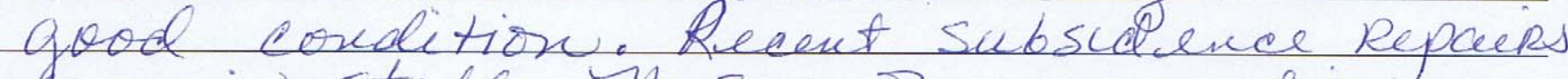

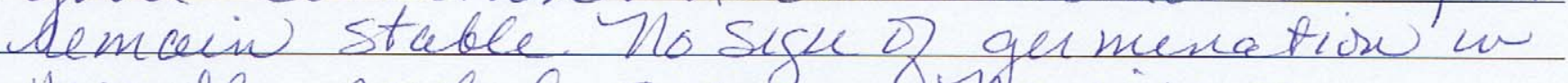

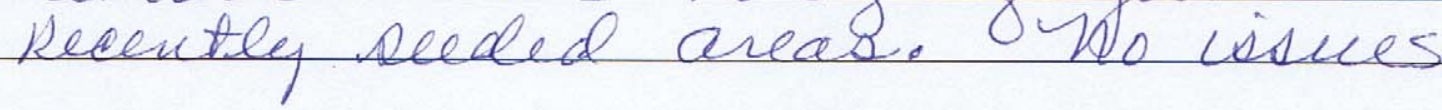

E. CERTIFICATION: I have conducted this inspection in accordance with the post-closure requirements as recorded on this checklist and attachments. Chief Inspector's Signature: /s/: Rebecca King

F. VERIFICATION: I have reviewed this checklist and attachments and have verified that they are complete. Signature: /s/: Reed Poderis

Printed Name: Thomas A. Thiele (or designee) 
POST-CLOSURE INSPECTION CHECKIIST

\section{CAU 111, AREA 5 WMD RETIRED MIXED WASTE PITS - CAS 05-21-01, MIXED WASTE PITS}

\begin{tabular}{||l|l|}
\hline \hline Inspection Date and Time: $3 / 2 / 3$ & Reason for Inspection: \\
\hline If this inspection is for a rain event, date of event: & Quantity of Rainfall: \\
\hline Date of Last Post-Closure Inspection: $\quad 12 / 18 / 2$ & Reason for Last Post-Closure Inspection: \\
\hline Responsible Entity: NSTec Environmental Restoration, Nevada National Security Site, Mercury, Nevada \\
\hline
\end{tabular}

Responsible Facility Owner: Thomas A. Thiele, Project Manager, Industrial Sites, Environmental Restoration Project

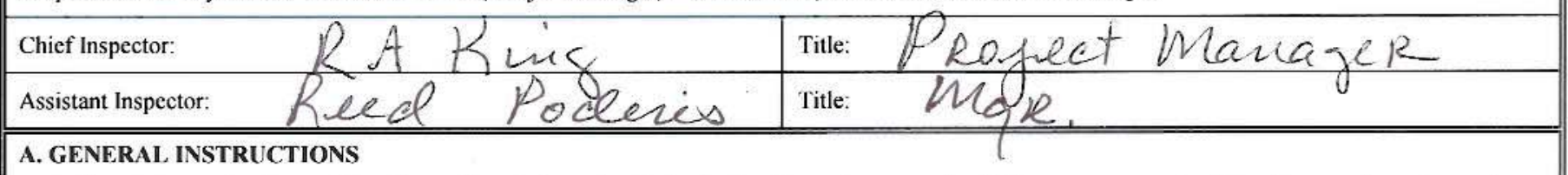

\section{A. GENERAL INSTRUCTIONS}

- The site inspection is a walking inspection of the entire site including the perimeter and sufficient transects to be able to inspect the entire surface and all features specifically described in this checklist. Complete this checklist during the site inspection.

- All documentation must be legible and clear. Complete all checklist items.

- If a shaded box is checked, add detailed comments to document the results of the site inspection. Information provided should be of sufficient detail to enable reconstruction of observations regarding field conditions. The completed checklist is part of the field record of the inspection.

- Field notes taken to assist in completion of this checklist will become part of the inspection record. No form is specified for field notes, and additional field notes are not required if the checklist and associated attachments adequately describe site conditions.

\begin{tabular}{||l|l|l|l||}
\hline \hline B. PREPARATION (To be completed prior to the site visit) & YES & NO & EXPLANATION (required if shaded box is checked) \\
\hline 1. Were anomalies or trends detected on previous inspections? & & & \\
\cline { 2 - 5 } $\begin{array}{l}\text { 2. Were maintenance or repair activities performed since the last } \\
\text { inspection? } \\
\text { a. If yes, has repair resulted in a change from as-built } \\
\begin{array}{c}\text { conditions? } \\
\text { b. If yes (to 4a), are revised as-built plans available that reflect } \\
\text { repair changes? }\end{array}\end{array}$ & & & \\
\cline { 2 - 5 }
\end{tabular}

C. SITE INSPECTION (To be completed during the site visit)

1. Adjacent Offsite Features:

a. Are there any new activities or offsite features that could potentially affect the site?

2. Site Markers:

a. Are all use restriction signs legible?

b. Are any use restriction signs damaged or missing?

c. How many damaged or missing signs need to be replaced?

d. Are any use restriction signs down or loose?

e. How many down or loose signs need to be re-hung?

f. Is there damage to any of the monuments?

3. Waste Unit Covers:

a. Is there evidence of settling or cracking?

b. Is there evidence of erosion (wind or water)?

c. Is there evidence of human intrusion onto the site?

d. Is there evidence of large animal intrusion onto the site?

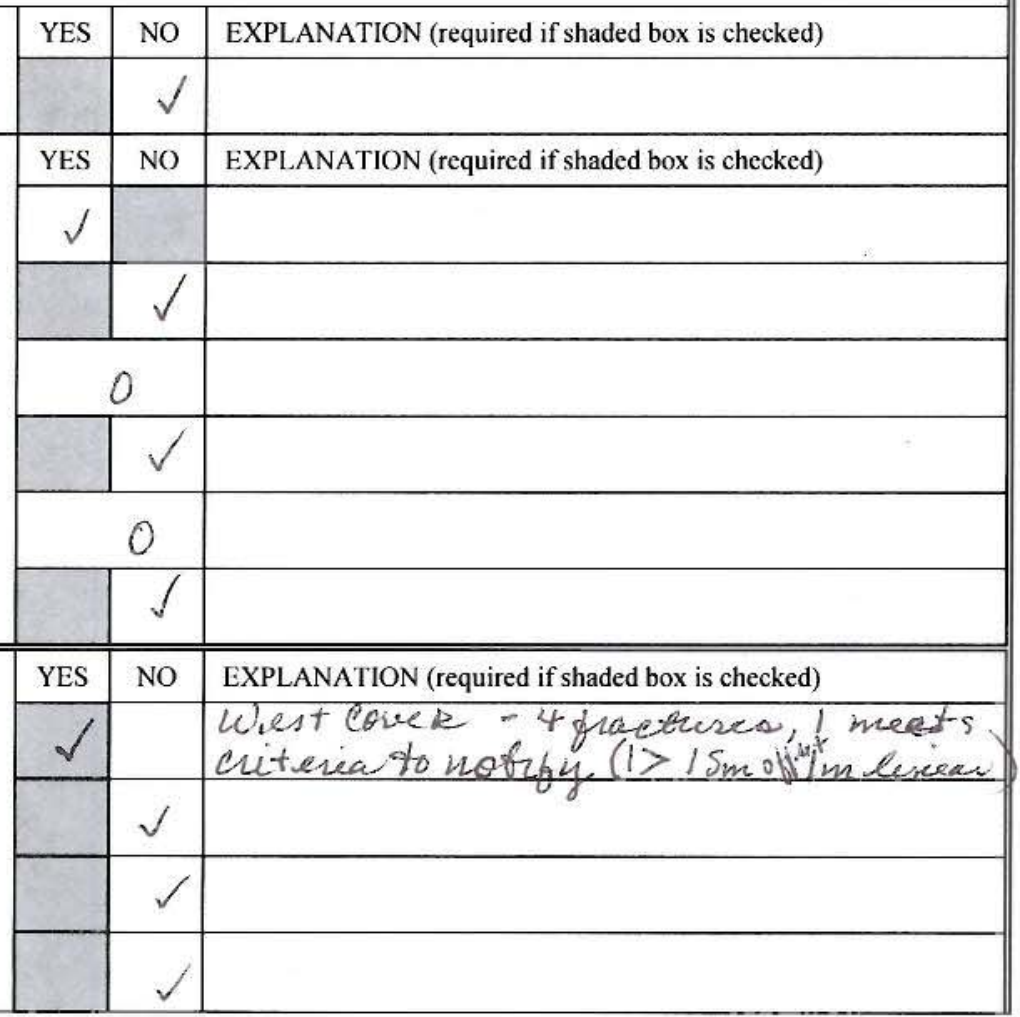




\section{POST-CLOSURE INSPECTION CHECKLIST}

\section{CAU 111, AREA 5 WMD RETIRED MIXED WASTE PITS - CAS 05-21-01, MIXED WASTE PITS}

c. Is there evidence of animal burrowing?

f. Is there a change in the vegetation growing on the cover?

g. Is there trash or debris on the cover?

h. Are there any other issues not specifically described in this checklist?

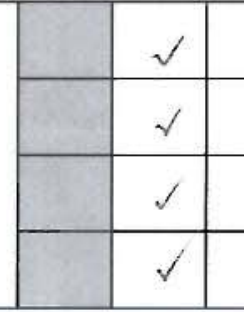

Photograph Instructions:

- A standard set of photographs is needed for the post-closure report. Photos are required to be taken from the approximate location where photos were taken the previous year (as found in the previous year's post-closure report).

- Photographs should also be taken to document maintenance/repair needs, anomalous features, or new features (such as changes in adjacent area land use). These will be used to plan maintenance/repair activities and are not intended for use in the annual post-closure report.

- Photographs will be filed electronically.

4. Photograph Documentation:

a. Have all required photographs of the site been taken?

\section{FIELD CONCLUSIONS}

1. Is general housckeeping or minor repair (including cracks or settling imperfections less than 15 centimeters deep that extend less than 1 meter on the cover) required?

2. Are there deficiencies that require a remedy other than general housekeeping or minor repair? (For example, are there cracks greater than 15 centimeters deep and 1 meter long on the cover?) Maintenance or repairs of cracks or settling imperfections greater than 15 centimeters deep and 1 meter long on the cover shall be completed within 60 days of discovery. Damaged or missing UR warning signs will be repaired or replaced within 60 days of discovery

3. Is there an imminent hazard to the integrity of the landfill cover?

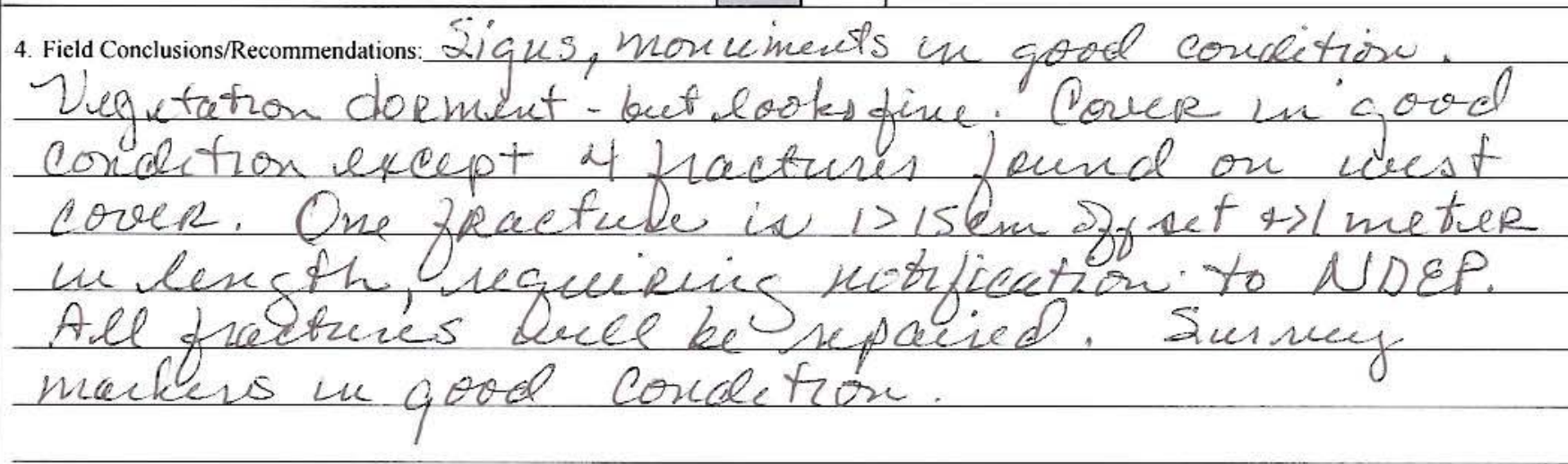

E. CERTIFICATION: I have conducted this inspection in accordance with the post-closure requirements as recorded on this checklist and attachments.

Chief Inspector's Signature: /s/: Rebecca King Date: $3 / 12 / 13$

F. VERIFICATION: I have reviewed this checklist and attachments and have verified that they are complete Signature:/S/: Reed Poderis Date: $3 / 18 / 2013$

Printed Name: Thomas A. Thiele (or designee) 


\section{POST-CLOSURE INSPECTION CHECKLIST}

\section{CAU 111, AREA 5 WMD RETIRED MIXED WASTE PITS - CAS 05-21-01, MIXED WASTE PITS}

\begin{tabular}{l|l|} 
Inspection Date: & If this inspection is for a rain event, date of event: \\
\hline Date of Last Post-Closure Inspection: & Quantity of Rainfall:
\end{tabular}

Responsible Facility Owner: Thomas A. Thiele, Project Manager, Industrial Sites, Environmental Restoration Project

Chief Inspector:

\section{A. GENERAL INSTRUCTIONS}

- The site inspection is a walking inspection of the entire site including the perimeter and sufficient transects to be able to inspect the entire surface and all features specifically described in this checklist. Complete this checklist during the site inspection.

- All documentation must be legible and clear. Complete all checklist items.

- If a shaded box is checked, add detailed comments to document the results of the site inspection. Information provided should be of sufficient detail to enable reconstruction of observations regarding field conditions. The completed checklist is part of the field record of the inspection.

- Field notes taken to assist in completion of this checklist will become part of the inspection record. No form is specified for field notes, and additional field notes are not required if the checklist and associated attachments adequately describe site conditions.

\begin{tabular}{|c|c|c|c|}
\hline B. PREPARATION (To be completed prior to the site visit) & YES & NO & EXPLANATION (required if shaded box is checked) \\
\hline \multicolumn{4}{|l|}{ 1. Were anomalies or trends detected on previous inspections? } \\
\hline $\begin{array}{l}\text { 2. Were maintenance or repair activities performed since the last } \\
\text { inspection? }\end{array}$ & & & \\
\hline $\begin{array}{l}\text { a. If yes, has repair resulted in a change from as-built } \\
\text { conditions? }\end{array}$ & & & NA \\
\hline $\begin{array}{l}\text { b. If yes (to } 4 \mathrm{a} \text { ), are revised as-built plans available that reflect } \\
\text { repair changes? }\end{array}$ & & & NA \\
\hline
\end{tabular}

C. SITE INSPECTION (To be completed during the site visit)

1. Adjacent Offsite Features:

a. Are there any new activities or offsite features that could potentially affect the site?

2. Site Markers:

a. Are all use restriction signs legible?

b. How many damaged or missing use restriction signs need to be replaced?

c. How many use restriction signs are down or loose and need to be re-hung?

d. Is there damage to any of the monuments?

3. Waste Unit Covers:

a. Is there evidence of settling or cracking?

b. Is there evidence of erosion (wind or water)?

c. Is there evidence of human intrusion onto the site?

d. Is there evidence of large animal intrusion onto the site?

e. Is there evidence of animal burrowing?

f. Is there a change in the vegetation growing on the cover?

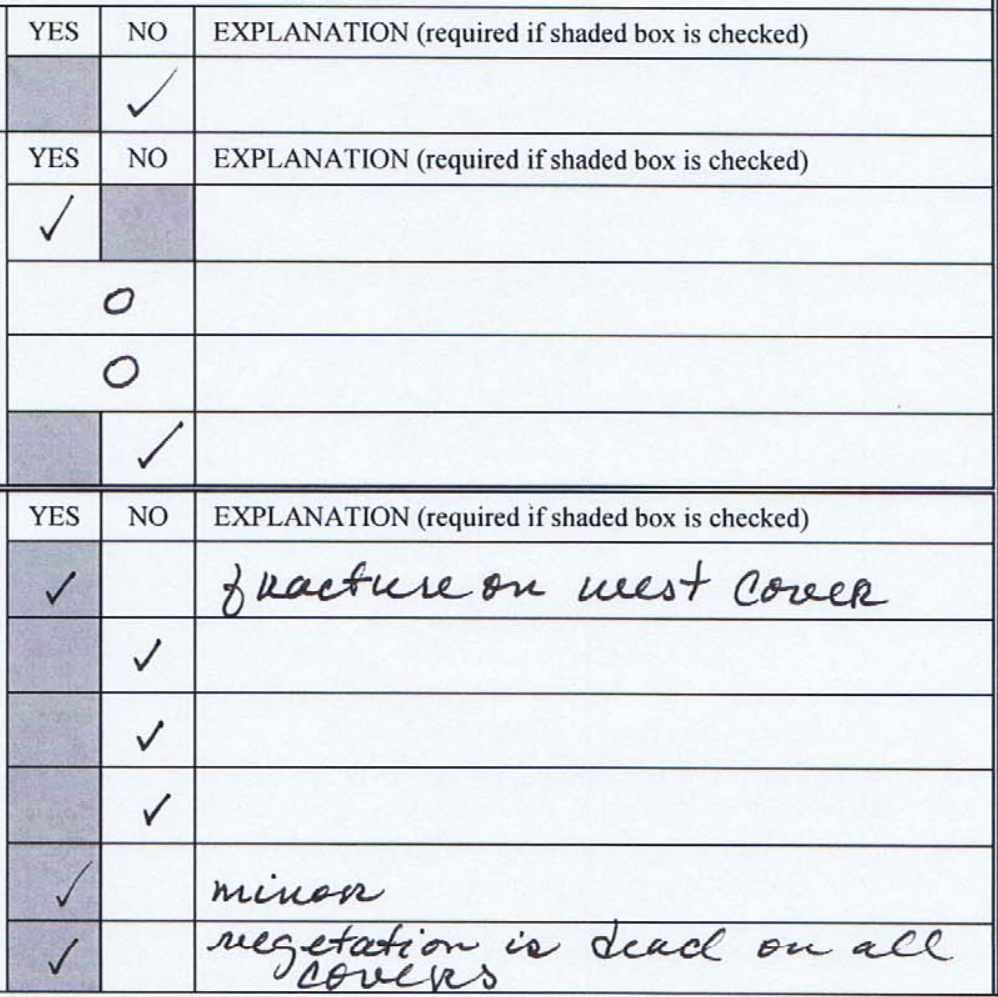




\section{POST-CLOSURE INSPECTION CHECKLIST}

\section{CAU 111, AREA 5 WMD RETIRED MIXED WASTE PITS - CAS 05-21-01, MIXED WASTE PITS}

g. Is there trash or debris on the cover?

h. Are there any other issues not specifically described in this checklist?

Photograph Instructions:

- A standard set of photographs is needed for the post-closure report. Photos are required to be taken from the approximate location where photos were taken the previous year (as found in the previous year's post-closure report).

- Photographs should also be taken to document maintenance/repair needs, anomalous features, or new features (such as changes in adjacent area land use). These will be used to plan maintenance/repair activities and are not intended for use in the annual post-closure report.

- Photographs will be filed electronically.

4. Photograph Documentation:

a. Have all required photographs of the site been taken?

\section{FIELD CONCLUSIONS}

1. Is general housekeeping or minor repair (including cracks or settling imperfections less than 15 centimeters deep that extend less than 1 meter on the cover) required?

2. Are there deficiencies that require a remedy other than general housekeeping or minor repair? (For example, are there cracks greater than 15 centimeters deep and 1 meter long on the cover?) Maintenance or repairs of cracks or settling imperfections greater than 15 centimeters deep and 1 meter long on the cover shall be completed within 60 days of discovery. Damaged or missing UR warning signs will be repaired or replaced within 60 days of discovery.

3 . Is there an imminent hazard to the integrity of the landfill cover?

4. Field Conclusions/Recommendations: $2, q u s$, movee merts + mankers in Good condition. Vegctation on corers Reclecies Resecding. A frecture on neest porek with areas igreetien than $15 \mathrm{~cm}$ t longer than 1 meter will be kepaired. Mo other issues.

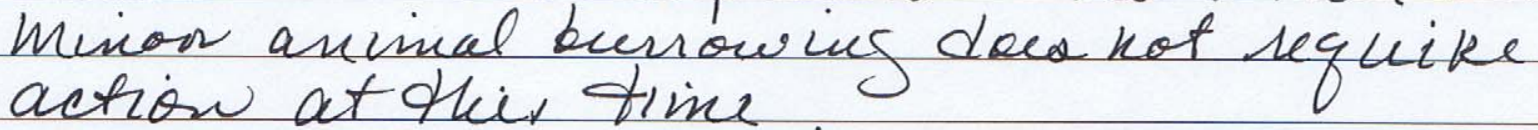

\begin{tabular}{|r|r|l|}
\hline YES & NO & EXPLANATION (required if shaded box is checked) \\
\hline$\checkmark$ & & \\
\hline YES & NO & EXPLANATION (required if shaded box is checked) \\
& $\checkmark$ & \\
& & Renuedcation of reegretcefion
\end{tabular}
$\checkmark$ and frueture kepen

E. CERTIFICATION: I have conducted this inspection in accordance with the post-closure requirements as recorded on this checklist and attachments.

Chief Inspector's Signature: /s/: Rebecca King

F. VERIFICATION: I have reviewed this checklist and attachments and have verified that they are complete.

Signature: /s/: Reed Poderis

Printed Name: Thomas A. Thiele (or designee)

Date: $6 / 18 / 13$

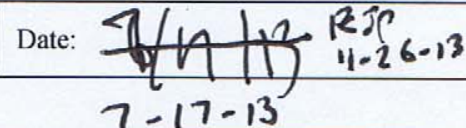




\section{POST-CLOSURE INSPECTION CHECKLIST}

\section{CAU 11, AREA 5 WMD RETIRED MIXED WASTE PITS - CAS 05-21-01, MIXED WASTE PITS}

\begin{tabular}{|l|l|}
\hline Inspection Date: & Reason for Inspection: \\
\hline If this inspection is for a rain event, date of event: & Quantity of Rainfall: \\
\hline Date of Last Post-Closure Inspection: $L / 181 / 3$ & Reason for Last Post-Closure Inspection: \\
\hline Responsible Entity: NSTec Environmental Restoration, Nevada National Security Site, Mercury, Nevada
\end{tabular}

Responsible Entity: NSTec Environmental Restoration, Nevada National Security Site, Mercury, Nevada

Responsible Facility Owner: Thomas A. Thiele, Project Manager, Industrial Sites, Environmental Restoration Project

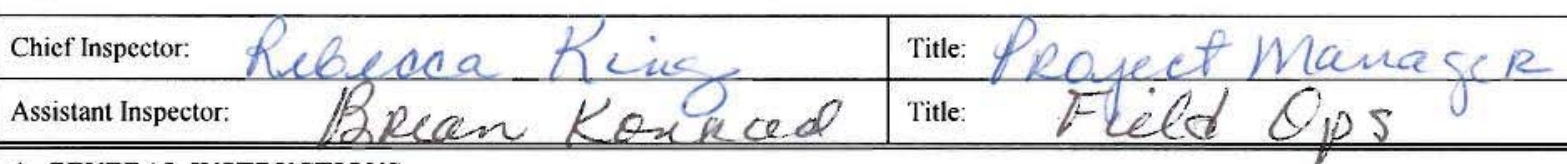

\section{A. GENERAL INSTRUCTIONS}

- The site inspection is a walking inspection of the entire site including the perimeter and sufficient transects to be able to inspect the entire surface and all features specifically described in this checklist. Complete this checklist during the site inspection.

- All documentation must be legible and clear. Complete all checklist items.

- If a shaded box is checked, add detailed comments to document the results of the site inspection. Information provided should be of sufficient detail to enable reconstruction of observations regarding field conditions. The completed checklist is part of the field record of the inspection.

- Field notes taken to assist in completion of this checklist will become part of the inspection record. No form is specified for field notes, and additional field notes are not required if the checklist and associated attachments adequately describe site conditions.

B. PREPARATION (To be completed prior to the site visit)

1. Were anomalies or trends detected on previous inspections?

2. Were maintenance or repair activities performed since the last inspection?

a. If yes, has repair resulted in a change from as-built conditions?

b. If yes (to 2a), are revised as-built plans available that reflect repair changes?

C. SITE INSPECTION (To be completed during the site visit)

1. Adjacent Offsite Features:

a. Are there any new activities or offsite features that could potentially affect the site?

2. Site Markers:

a. Are all use restriction signs legible?

b. How many damaged or missing use restriction signs need to be replaced?

c. How many use restriction signs are down or loose and need to be re-hung?

d. Is there damage to any of the monuments?

3. Waste Unit Covers:

a. Is there evidence of settling or cracking?

b. Is there evidence of erosion (wind or water)?

c. Is there evidence of human intrusion onto the site?

d. Is there evidence of large animal intrusion onto the site?

e. Is there evidence of animal burrowing?

f. Is there a change in the vegetation growing on the cover?

\begin{tabular}{|c|c|l|l||}
\hline YES & NO & \multicolumn{2}{||}{ EXPLANATION (required if shaded box is checked) } \\
\hline & $\checkmark$ & \multicolumn{2}{|c||}{} \\
\hline & & \multicolumn{2}{|c|}{ fract ure Repaik } \\
\hline & $\checkmark$ & NA & \\
\hline & & NA & \\
\hline
\end{tabular}

\begin{tabular}{|c|c|c|}
\hline YES & NO & EXPLANATION (required if shaded box is checked) \\
\hline YES & NO & EXPLANATION (required if shaded box is checked) \\
\hline & 0 & \\
\hline & 0 & \\
\hline & & \\
\hline YES & NO & EXPLANATION (required if shaded box is checked) \\
\hline$\checkmark$ & & DeC, D. 4 \\
\hline$\checkmark$ & & see D. 4 \\
\hline & $\checkmark$ & \\
\hline & $\checkmark$ & \\
\hline$\checkmark$ & & see D. $y$ \\
\hline & $\mathcal{J}$ & \\
\hline
\end{tabular}




\section{POST-CLOSURE INSPECTION CHECKLIST}

\section{CAU 111, AREA 5 WMD RETIRED MIXED WASTE PITS - CAS 05-21-01, MIXED WASTE PITS}

g. Is there trash or debris on the cover?

h. Are there any other issues not specifically described in this checklist?

Photograph Instructions:

- A standard set of photographs is needed for the post-closure report. Photos are required to be taken from the approximate location where photos were taken the previous year (as found in the previous year's post-closure report).

- Photographs should also be taken to document maintenance/repair needs, anomalous features, or new features (such as changes in adjacent area land use). These will be used to plan maintenance/repair activities and are not intended for use in the annual post-closure report.

- Photographs will be filed electronically.

4. Photograph Documentation:

a. Have all required photographs of the site been taken?

\section{FIELD CONCLUSIONS}

1. Is general housekeeping or minor repair (including cracks or settling imperfections less than 15 centimeters deep that extend less than 1 meter on the cover) required?

2. Are there deficiencies that require a remedy other than general housekeeping or minor repair? (For example, are there cracks greater than 15 centimeters deep and 1 meter long on the cover?) Maintenance or repairs of cracks or settling imperfections greater than 15 centimeters deep and 1 meter long on the cover shall be completed within 60 days of discovery. Damaged or missing UR warning signs will be repaired or replaced within 60 days of discovery.

3. Is there an imminent hazard to the integrity of the landfill cover?

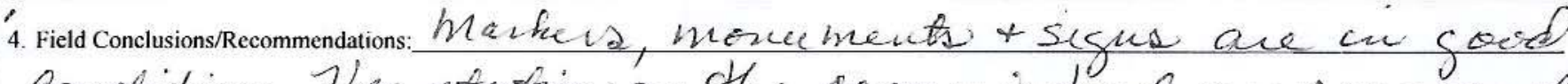

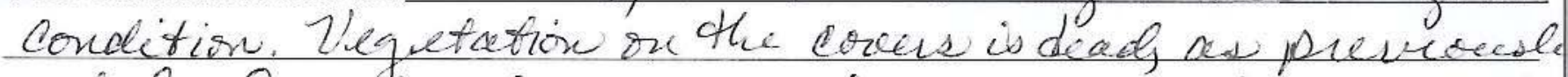

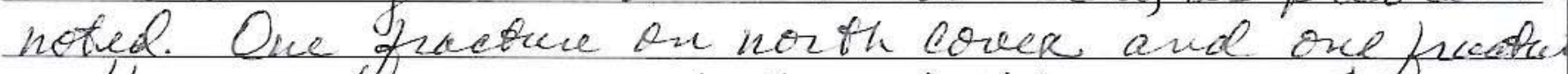

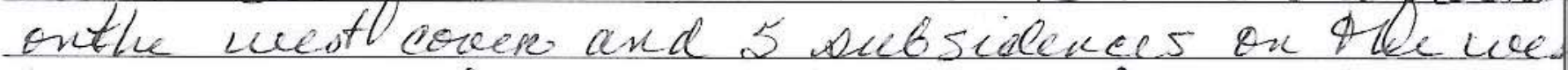

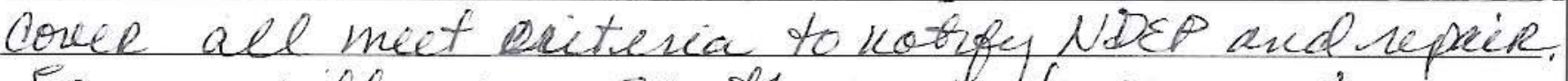

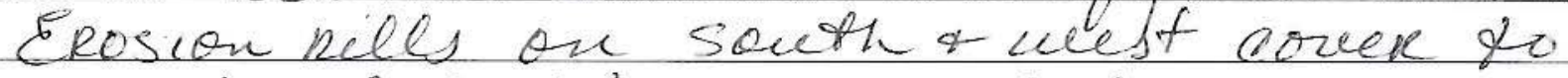

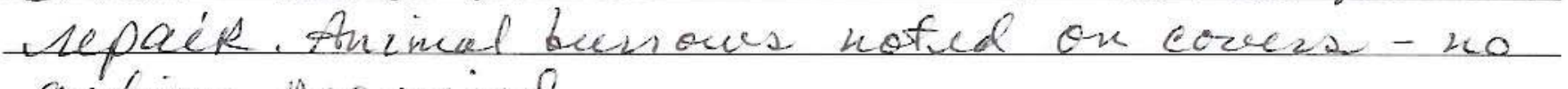
action inesceised.

E. CERTIFICATION: 1 have conducted this inspection in accordance with the post-closure requirements as recorded on this checklist and attachments.

Chief Inspector's Signature: /S/: Rebecca King

F. VERIFICATION: I have reviewed this checklist and attachments and have verified that they are complete.

Signature: /s/: Reed Poderis

Date: $4 / 17 / 15$

Printed Name: Thomas A. Thiele (or designee) 
RCRA Post-Closure Report

Revision: 0

Date: January 2014

Corrective ACtion Unit 112 InSPECTION CheCKLISTS 
RCRA Post-Closure Report

Revision: 0

Date: January 2014

\section{THIS PAGE INTENTIONALLY LEFT BLANK}




\section{POST-CLOSURE INSPECTION CHECKLIST}

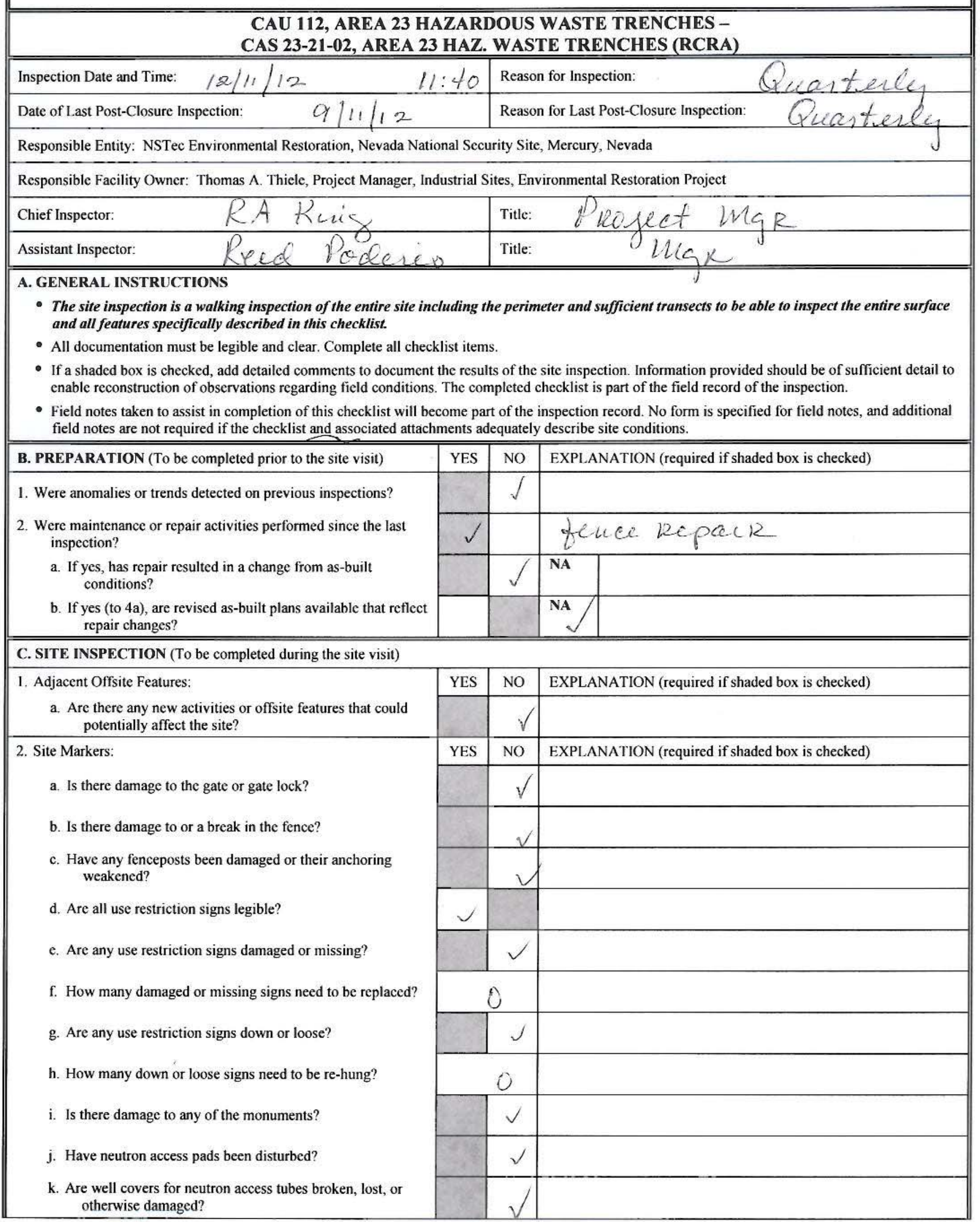




\section{POST-CLOSURE INSPECTION CHECKLIST}

\section{CAU 112, AREA 23 HAZARDOUS WASTE TRENCHES -}

CAS 23-21-02, AREA 23 HAZ. WASTE TRENCHES (RCRA)

\section{Waste Unit Covers:}

a. Is there evidence of settling or cracking?

b. Is there evidence of erosion (wind or water)?

c. Is there evidence of human intrusion onto the site?

d. Is there evidence of large animal intrusion onto the site?

e. Is there evidence of animal burrowing?

f. Is there vegetation growing on the cover?

g. Is there trash or debris within the fenced area?

h. Are there any other issues not specifically described in this checklist?

\begin{tabular}{|r|r|l||}
\hline YES & NO & EXPLANATION (required if shaded box is checked) \\
\hline & $\sqrt{ }$ & \\
\hline & $\sqrt{ }$ & \\
\hline & $\sqrt{ }$ & \\
\hline & $\sqrt{ }$ & \\
\hline & $\sqrt{ }$ & \\
\hline & $\sqrt{ }$ & \\
\hline & $\sqrt{ }$ & \\
\hline & $\sqrt{ }$ \\
\hline
\end{tabular}

Photograph Instructions:

- Photographs should be taken to document maintenance/repair needs, anomalous features, or new features (such as changes in adjacent area land use).

These will be used to plan maintenance/repair activities and are not intended for use in the annual post-closure report.

- Other photographs are optional.

- Photographs will be filed electronically.

4. Photograph Documentation:

a. Have photographs of the site been taken?

\begin{tabular}{||l|c|c|l|}
\hline \hline D. FIELD CONCLUSIONS & YES & NO & EXPLANATION (required if shaded box is checked) \\
\hline 1. Is maintenance/repair necessary? & & & \\
\hline 2. Is there an imminent hazard to the integrity of the landfill cover? & & $\sqrt{ }$ & \\
\hline
\end{tabular}

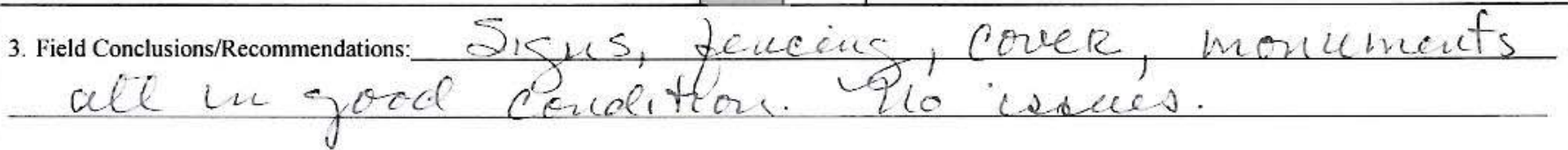

E. CERTIFICATION: 1 have conducted this inspection in accordance with the post-closure requirements as recorded on this checklist and attachments.

Chief Inspector's Signature: /s/: Rebecca King

Date: $12 / 11 / 12$

F. VERIFICATION: I have reviewed this checklist and attachments and have verified that they are complete.

Signature: /s/: Reed Poderis - $\quad$ Date: $/ 2 / 17 / 2$

Printed Name: Thomas A. Thiele (or designee) 


\section{POST-CLOSURE INSPECTION CHECKLIST}

\section{CAU 112, AREA 23 HAZARDOUS WASTE TRENCHES -}

CAS 23-21-02, AREA 23 HAZ. WASTE TRENCHES (RCRA)

\begin{tabular}{|l|l|l|l|l|}
\hline \hline Inspection Date and Time: & Reason for Inspection: \\
\hline Responsible Entity: NSTec Environmental Restoration, Nevada National Security Site, Mercury, Nevada
\end{tabular}

Responsible Facility Owner: Thomas A. Thiele, Project Manager, Industrial Sites, Environmental Restoration Project

Chief Inspector: $\quad$ Teede

\section{A. GENERAL INSTRUCTIONS}

- The site inspection is a walking inspection of the entire site including the perimeter and sufficient transects to be able to inspect the entire surface and all features specifically described in this checklist.

- All documentation must be legible and clear. Complete all checklist items.

- If a shaded box is checked, add detailed comments to document the results of the site inspection. Information provided should be of sufficient detail to enable reconstruction of observations regarding field conditions. The completed checklist is part of the field record of the inspection.

- Field notes taken to assist in completion of this checklist will become part of the inspection record. No form is specified for field notes, and additional field notes are not required if the checklist and associated attachments adequately describe site conditions.

\section{B. PREPARATION (To be completed prior to the site visit)}

1. Were anomalies or trends detected on previous inspections?

2. Were maintenance or repair activities performed since the last inspection?

a. If yes, has repair resulted in a change from as-built conditions?

b. If yes (to $4 \mathrm{a}$ ), are revised as-built plans available that reflect repair changes?

\begin{tabular}{|r|r|l|l|}
\hline YES & NO & \multicolumn{2}{l|}{ EXPLANATION (required if shaded box is checked) } \\
\hline & $\sqrt{ }$ & \\
\hline & & NA $/$ & \\
\hline & & NA $/$ & \\
\hline
\end{tabular}

C. SITE INSPECTION (To be completed during the site visit)

1. Adjacent Offsite Features:

a. Are there any new activities or offsite features that could potentially affect the site?

\section{Site Markers:}

a. Is there damage to the gate or gate lock?

b. Is there damage to or a break in the fence?

c. Have any fenceposts been damaged or their anchoring weakened?

d. Are all use restriction signs legible?

e. Are any use restriction signs damaged or missing?

f. How many damaged or missing signs need to be replaced?

g. Are any use restriction signs down or loose?

h. How many down or loose signs need to be re-hung?

i. Is there damage to any of the monuments?

j. Have neutron access pads been disturbed?

k. Are well covers for neutron access tubes broken, lost, or otherwise damaged?

\begin{tabular}{|r|r|l||}
\hline YES & NO & EXPLANATION (required if shaded box is checked) \\
\hline & \multicolumn{1}{|c||}{} \\
\hline YES & NO & EXPLANATION (required if shaded box is checked) \\
\hline & $\sqrt{ }$ & \\
\hline & $\checkmark$ & \\
\hline$\checkmark$ & & \\
\hline & $\checkmark$ & \\
\hline & 0 & \\
\hline & $\checkmark$ & \\
\hline & & \\
\hline & $\checkmark$ & \\
\hline & $\checkmark$ & \\
\hline
\end{tabular}




\section{POST-CLOSURE INSPECTION CHECKLIST}

\section{CAU 112, AREA 23 HAZARDOUS WASTE TRENCHES -}

CAS 23-21-02, AREA 23 HAZ. WASTE TRENCHES (RCRA)

3. Waste Unit Covers:

a. Is there evidence of settling or cracking?

b. Is there evidence of erosion (wind or water)?

c. Is there evidence of human intrusion onto the site?

d. Is there evidence of large animal intrusion onto the site?

e. Is there evidence of animal burrowing?

f. Is there vegetation growing on the cover?

g. Is there trash or debris within the fenced area?

h. Are there any other issues not specifically described in this checklist?

\begin{tabular}{|c|c|c|}
\hline YES & NO & EXPLANATION (required if shaded box is checked) \\
\hline & $\sqrt{ }$ & \\
\hline & \multicolumn{1}{|c}{} \\
\hline & $\checkmark$ & \\
\hline & $\checkmark$ & \\
\hline & & on top and slopes of cover \\
\hline & & \\
\hline & & \\
\end{tabular}

Photograph Instructions:

- Photographs should be taken to document maintenance/repair needs, anomalous features, or new features (such as changes in adjacent area land use). These will be used to plan maintenance/repair activities and are not intended for use in the annual post-closure report.

- Other photographs are optional.

- Photographs will be filed electronically.

4. Photograph Documentation:

a. Have photographs of the site been taken?

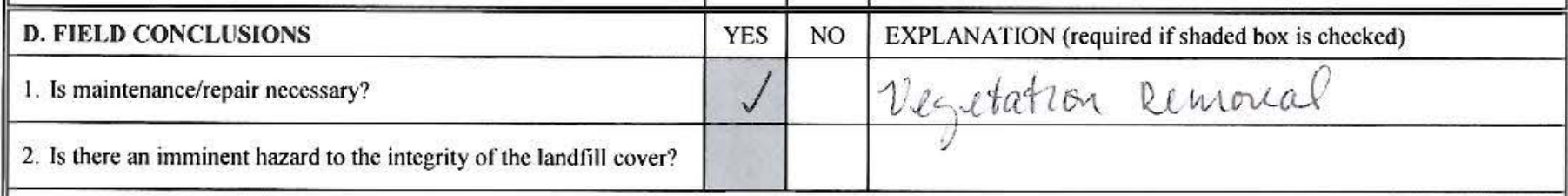

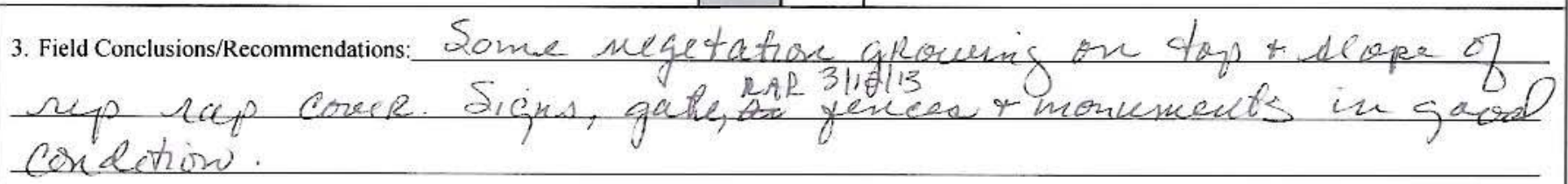

E. CERTIFICATION: I have conducted this inspection in accordance with the post-closure requirements as recorded on this checklist and attachments.

Chief Inspector's Signature: /s/: Rebecca King Date: $3 / 12 / 13$

F. VERIFICATION: I have reviewed this checklist and attachments and have verified that they are complete.

\begin{tabular}{l|l} 
Signature: /S/: Reed Poderis & Date: $3 / 13 / 2013$
\end{tabular}

Printed Name: Thomas $\mathrm{A}$. Thiele (or designee) 


\section{POST-CLOSURE INSPECTION CHECKLIST}

\section{CAU 112, AREA 23 HAZARDOUS WASTE TRENCHES - \\ CAS 23-21-02, AREA 23 HAZ. WASTE TRENCHES (RCRA)}

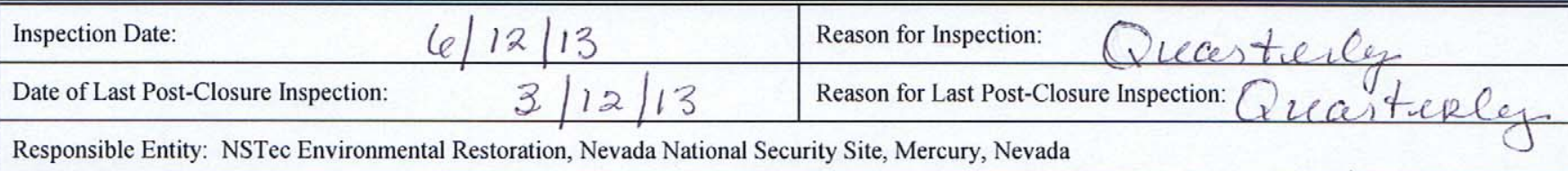

Responsible Facility Owner: Thomas A. Thiele, Project Manager, Industrial Sites, Environmental Restoration Project

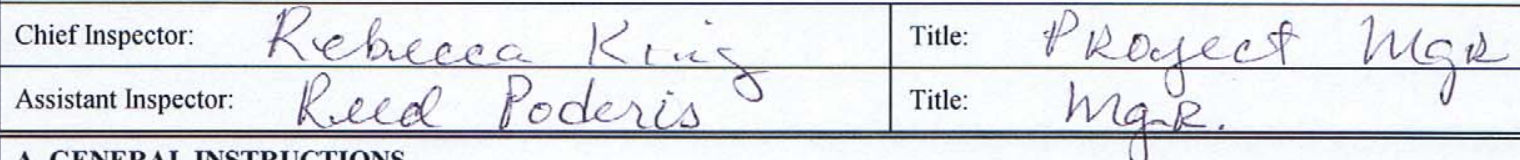

\section{A. GENERAL INSTRUCTIONS}

- The site inspection is a walking inspection of the entire site including the perimeter and sufficient transects to be able to inspect the entire surface and all features specifically described in this checklist.

- All documentation must be legible and clear. Complete all checklist items.

- If a shaded box is checked, add detailed comments to document the results of the site inspection. Information provided should be of sufficient detail to enable reconstruction of observations regarding field conditions. The completed checklist is part of the field record of the inspection.

- Field notes taken to assist in completion of this checklist will become part of the inspection record. No form is specified for field notes, and additional field notes are not required if the checklist and associated attachments adequately describe site conditions.

B. PREPARATION (To be completed prior to the site visit)

1. Were anomalies or trends detected on previous inspections?

2. Were maintenance or repair activities performed since the last inspection?

a. If yes, has repair resulted in a change from as-built conditions?

b. If yes (to 2a), are revised as-built plans available that reflect repair changes?

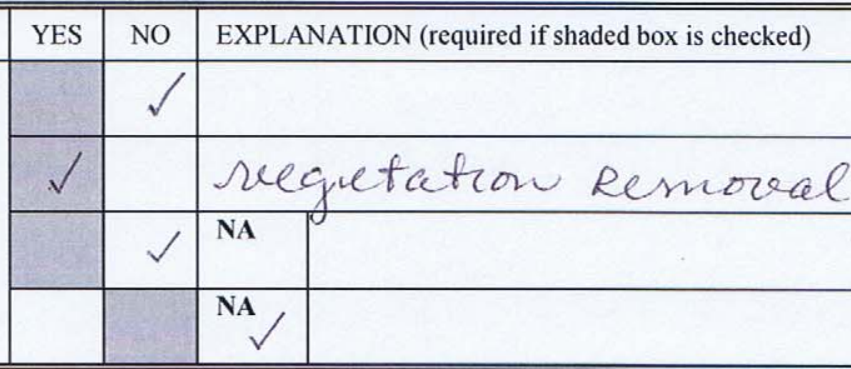

C. SITE INSPECTION (To be completed during the site visit)

1. Adjacent Offsite Features:

a. Are there any new activities or offsite features that could potentially affect the site?

2. Site Markers:

a. Is there damage to the gate or gate lock?

b. Is there damage to or a break in the fence?

c. Have any fenceposts been damaged or their anchoring weakened?

d. Are all use restriction signs legible?

e. How many damaged or missing use restriction signs need to be replaced?

f. How many use restriction signs are down or loose and need to be re-hung?

g. Is there damage to any of the monuments?

h. Have neutron access pads been disturbed?

i. Are well covers for neutron access tubes broken, lost, or otherwise damaged?

3. Waste Unit Covers:

a. Is there evidence of settling or cracking?

b. Is there evidence of erosion (wind or water)?

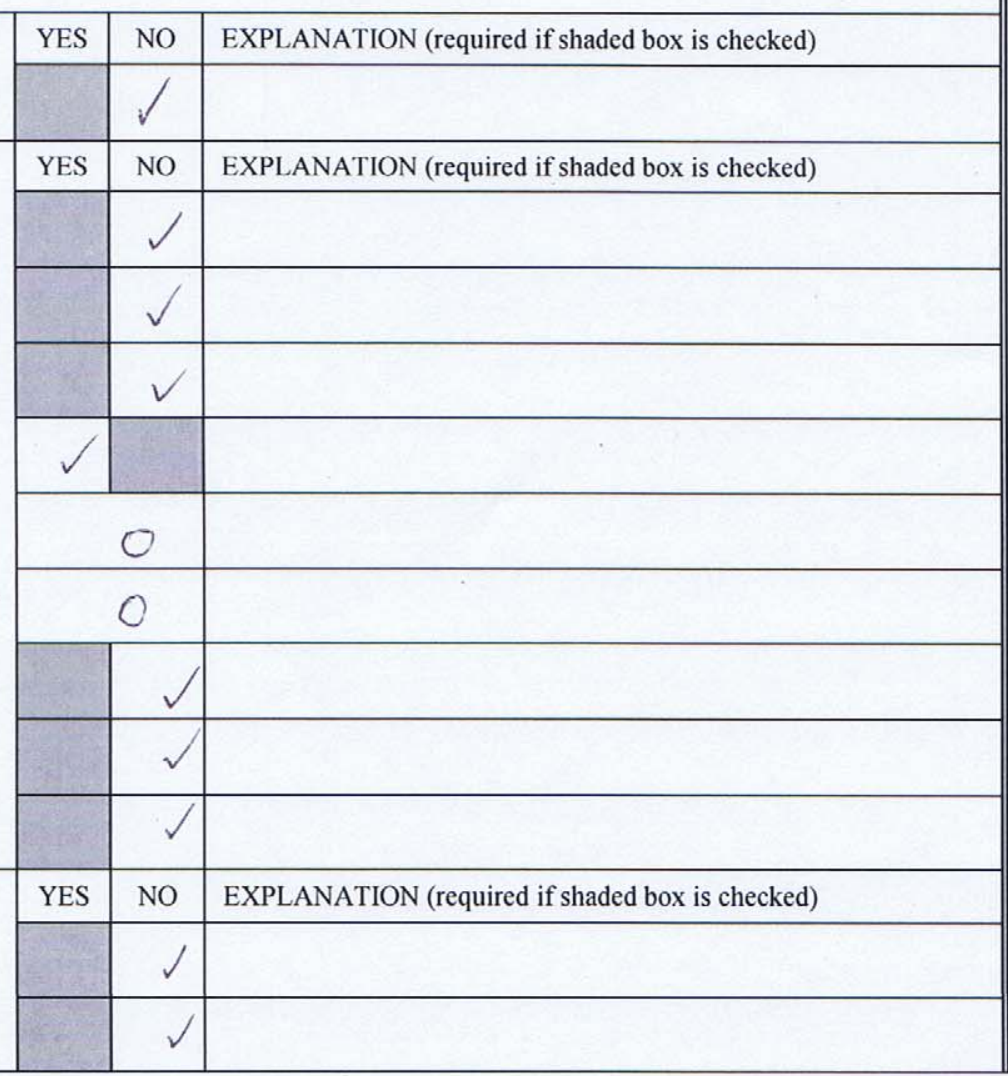

Page 1 of 2 


\section{POST-CLOSURE INSPECTION CHECKLIST}

\section{CAU 112, AREA 23 HAZARDOUS WASTE TRENCHES - \\ CAS 23-21-02, AREA 23 HAZ. WASTE TRENCHES (RCRA)}

c. Is there evidence of human intrusion onto the site?

d. Is there evidence of large animal intrusion onto the site?

e. Is there evidence of animal burrowing?

f. Is there vegetation growing on the cover?

g. Is there trash or debris within the fenced area?

h. Are there any other issues not specifically described in this checklist?

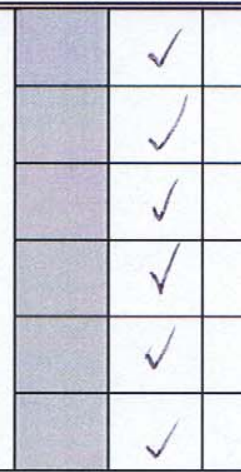

\section{Photograph Instructions:}

- Photographs should be taken to document maintenance/repair needs, anomalous features, or new features (such as changes in adjacent area land use). These will be used to plan maintenance/repair activities and are not intended for use in the annual post-closure report.

- Other photographs are optional.

- Photographs will be filed electronically.

4. Photograph Documentation:

a. Have photographs of the site been taken?

\begin{tabular}{||l|}
\hline \hline D. FIELD CONCLUSIONS \\
\hline 1. Is there an imminent hazard to the integrity of the landfill cover? \\
\hline
\end{tabular}

2. Field Conclusions and Repair or Maintenance Recommendations:

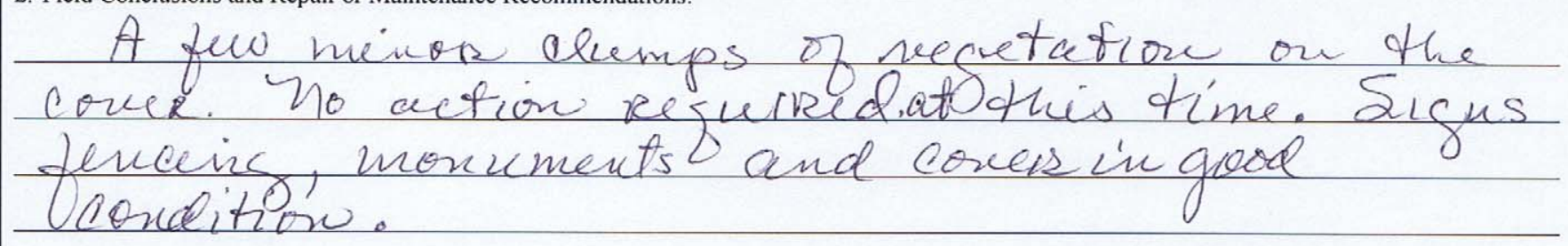

E. CERTIFICATION: I have conducted this inspection in accordance with the post-closure requirements as recorded on this checklist and attachments.

Chief Inspector's Signature: /s/: Rebecca King

Date: 6112113

F. VERIFICATION: I have reviewed this checklist and attachments and have verified that they are complete. Signature: /s/: Reed Poderis

Date: $7 / 17 / 13$

Printed Name: Thomas A. Thiele (or designee) 


\section{POST-CLOSURE INSPECTION CHECKLIST}

\section{CAU 112, AREA 23 HAZARDOUS WASTE TRENCHES - \\ CAS 23-21-02, AREA 23 HAZ. WASTE TRENCHES (RCRA)}

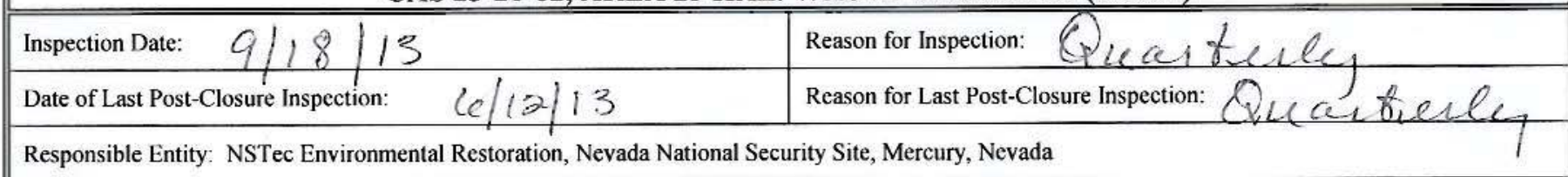

Responsible Facility Owner: Thomas A. Thiele, Project Manager, Industrial Sites, Environmental Restoration Project

Chief Inspector: Aceboeqea

\section{A. GENERAL INSTRUCTIONS}

- The site inspection is a walking inspection of the entire site including the perimeter and sufficient transects to be able to inspect the entire surface and all features specifically described in this checklist.

- All documentation must be legible and clear. Complete all checklist items.

- If a shaded box is checked, add detailed comments to document the results of the site inspection. Information provided should be of sufficient detail to enable reconstruction of observations regarding field conditions. The completed checklist is part of the field record of the inspection.

- Field notes taken to assist in completion of this checklist will become part of the inspection record. No form is specified for field notes, and additional field notes are not required if the checklist and associated attachments adequately describe site conditions.

\section{B. PREPARATION (To be completed prior to the site visit)}

1. Were anomalies or trends detected on previous inspections?

2. Were maintenance or repair activities performed since the last inspection?

a. If yes, has repair resulted in a change from as-built conditions?

b. If yes (to 2a), are revised as-built plans available that reflect repair changes?

\begin{tabular}{|c|c|c|}
\hline YES & NO & EXPLANATION (required if shaded box is checked) \\
\hline & & \\
\hline & & \\
\hline & & \\
\hline
\end{tabular}

C. SITE INSPECTION (To be completed during the site visit)

1. Adjacent Offsite Features:

a. Are there any new activities or offsite features that could potentially affect the site?

\section{Site Markers:}

a. Is there damage to the gate or gate lock?

b. Is there damage to or a break in the fence?

c. Have any fenceposts been damaged or their anchoring weakened?

d. Are all use restriction signs legible?

e. How many damaged or missing use restriction signs need to be replaced?

f. How many use restriction signs are down or loose and need to be re-hung?

g. Is there damage to any of the monuments?

h. Have neutron access pads been disturbed?

i. Are well covers for neutron access tubes broken, lost, or otherwise damaged?

3. Waste Unit Covers:
a. Is there evidence of settling or cracking?
b. Is there evidence of erosion (wind or water)?

\begin{tabular}{|c|c|c|}
\hline YES & $\mathrm{NO}$ & EXPLANATION (required if shaded box is checked) \\
\hline YES & NO & EXPLANATION (required if shaded box is checked) \\
\hline & & 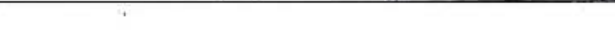 \\
\hline & & \\
\hline & & \\
\hline & & \\
\hline & & \\
\hline & & \\
\hline & & \\
\hline & & \\
\hline & & \\
\hline YES & NO & EXPLANATION (required if shaded box is checked) \\
\hline & & \\
\hline & & \\
\hline
\end{tabular}




\section{POST-CLOSURE INSPECTION CHECKLIST \\ CAU 112, AREA 23 HAZARDOUS WASTE TRENCHES - \\ CAS 23-21-02, AREA 23 HAZ. WASTE TRENCHES (RCRA)}

c. Is there evidence of human intrusion onto the site?

d. Is there evidence of large animal intrusion onto the site?

e. Is there evidence of animal burrowing?

f. Is there vegetation growing on the cover?

g. Is there trash or debris within the fenced area?

h. Are there any other issues not specifically described in this checklist?

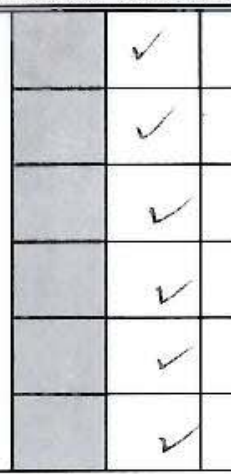

Photograph Instructions:

- Photographs should be taken to document maintenance/repair needs, anomalous features, or new features (such as changes in adjacent area land use).

These will be used to plan maintenance/repair activities and are not intended for use in the annual post-closure report.

- Other photographs are optional.

- Photographs will be filed electronically.

4. Photograph Documentation:

a. Have photographs of the site been taken?

\section{FIELD CONCLUSIONS}

1. Is there an imminent hazard to the integrity of the landfill cover?

\begin{tabular}{|c|c|c|}
\hline YES & NO & EXPLANATION \\
\hline YES & NO & EXPLANATION (required if shaded box is checked) \\
\hline & & \\
\hline
\end{tabular}

2. Field Conclusions and Repair or Maintenance Recommendations:

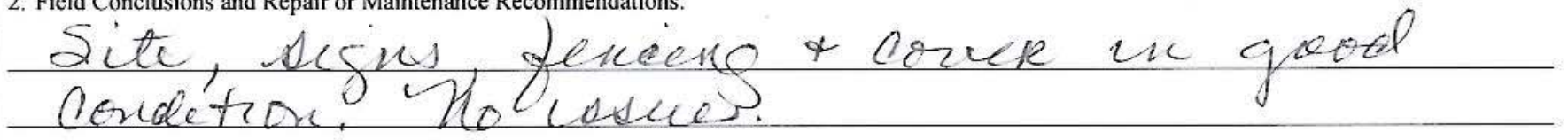

E. CERTIFICATION: I have conducted this inspection in accordance with the post-closure requirements as recorded on this checklist and attachments. Chief Inspector's Signature: /s/: Rebecca King

F. VERIFICATION: I have reviewed this checklist and attachments and have verified that they are complete.

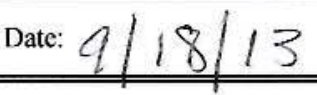

Signature: /S/: Reed Poderis

Date: $9 / 24 / 13$

Printed Name: Thomas A. Thiele (or designee) 
RCRA Post-Closure Report

Revision: 0

Date: January 2014

\section{APPENDIX B} PHOTOGRAPHS 
RCRA Post-Closure Report

Revision: 0

Date: January 2014

\section{THIS PAGE INTENTIONALLY LEFT BLANK}


PhOTOGRAPH Log

\begin{tabular}{|c|c|c|c|}
\hline CAU & DATE & P PHOTO NUMBER & DESCRIPTION \\
\hline \multirow{12}{*}{90} & \multirow{6}{*}{$12 / 11 / 2012$} & 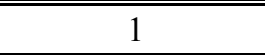 & "West Unit Facing North \\
\hline & & 2 & West Unit Facing East \\
\hline & & 3 & West Unit Facing South \\
\hline & & 4 & East Unit Facing South \\
\hline & & 5 & East Unit Facing West \\
\hline & & 6 & East Unit Facing North \\
\hline & \multirow{6}{*}{$06 / 12 / 2013$} & 7 & West Unit Facing North \\
\hline & & 8 & West Unit Facing East \\
\hline & & 9 & West Unit Facing South \\
\hline & & 10 & East Unit Facing South \\
\hline & & 11 & East Unit Facing West \\
\hline & & 12 & East Unit Facing North \\
\hline \multirow{16}{*}{91} & \multirow{8}{*}{$03 / 12 / 2013$} & 13 & Inside Facing North \\
\hline & & 14 & Inside Facing East \\
\hline & & 15 & Inside Facing South \\
\hline & & 16 & Inside Facing West \\
\hline & & 17 & Outside Facing North \\
\hline & & 18 & Outside Facing East \\
\hline & & 19 & Outside Facing South \\
\hline & & 20 & Outside Facing West \\
\hline & \multirow{8}{*}{$09 / 17 / 2013$} & 21 & Inside Facing North \\
\hline & & 22 & Inside Facing East \\
\hline & & 23 & Inside Facing South \\
\hline & & 24 & Inside Facing West \\
\hline & & 25 & Outside Facing North \\
\hline & & 26 & Outside Facing East \\
\hline & & 27 & Outside Facing South \\
\hline & & 28 & Outside Facing West \\
\hline \multirow{12}{*}{92} & \multirow{4}{*}{$12 / 11 / 2012$} & 29 & Outside Facing North \\
\hline & & 30 & Outside Facing East \\
\hline & & 31 & Outside Facing South \\
\hline & & 32 & Outside Facing West \\
\hline & \multirow{8}{*}{$03 / 12 / 2013$} & 33 & Inside Facing North \\
\hline & & 34 & Inside Facing East \\
\hline & & 35 & Inside Facing South \\
\hline & & 36 & Inside Facing West \\
\hline & & 37 & Outside Facing North \\
\hline & & 38 & Outside Facing East \\
\hline & & 39 & Outside Facing South \\
\hline & & 40 & Outside Facing West \\
\hline
\end{tabular}




\section{PHOTOGRAPH LOG}

\begin{tabular}{|c|c|c|c|}
\hline CAU & DATE & PHOTO NUMBER & DESCRIPTION \\
\hline \multirow{16}{*}{92} & \multirow{8}{*}{$06 / 12 / 2013$} & 41 & Inside Facing North \\
\hline & & 42 & Inside Facing East \\
\hline & & 43 & Inside Facing South \\
\hline & & 44 & Inside Facing West \\
\hline & & 45 & Outside Facing North \\
\hline & & 46 & Outside Facing East \\
\hline & & 47 & Outside Facing South \\
\hline & & 48 & Outside Facing West \\
\hline & \multirow{8}{*}{$09 / 18 / 2013$} & 49 & Inside Facing North \\
\hline & & 50 & Inside Facing East \\
\hline & & 51 & Inside Facing South \\
\hline & & 52 & Inside Facing West \\
\hline & & 53 & Outside Facing North \\
\hline & & 54 & Outside Facing East \\
\hline & & 55 & Outside Facing South \\
\hline & & 56 & Outside Facing West \\
\hline \multirow{24}{*}{110} & \multirow{8}{*}{$12 / 11 / 2012$} & 57 & Inside Facing North \\
\hline & & 58 & Inside Facing East \\
\hline & & 59 & Inside Facing South \\
\hline & & 60 & Inside Facing West \\
\hline & & 61 & Outside Facing North \\
\hline & & 62 & Outside Facing East \\
\hline & & 63 & Outside Facing South \\
\hline & & 64 & Outside Facing West \\
\hline & \multirow{8}{*}{$03 / 12 / 2013$} & 65 & Inside Facing North \\
\hline & & 66 & Inside Facing East \\
\hline & & 67 & Inside Facing South \\
\hline & & 68 & Inside Facing West \\
\hline & & 69 & Outside Facing North \\
\hline & & 70 & Outside Facing East \\
\hline & & 71 & Outside Facing South \\
\hline & & 72 & Outside Facing West \\
\hline & \multirow{8}{*}{$06 / 12 / 2013$} & 73 & Inside Facing North \\
\hline & & 74 & Inside Facing East \\
\hline & & 75 & Inside Facing South \\
\hline & & 76 & Inside Facing West \\
\hline & & 77 & Outside Facing North \\
\hline & & 78 & Outside Facing East \\
\hline & & 79 & Outside Facing South \\
\hline & & 80 & Outside Facing West \\
\hline
\end{tabular}


PhOTOGRAPH Log

\begin{tabular}{|c|c|c|c|}
\hline CAU & DATE & PHOTO NUMBER & DESCRIPTION \\
\hline \multirow{8}{*}{110} & \multirow{8}{*}{$09 / 17 / 2013$} & 81 & Inside Facing North \\
\hline & & 82 & Inside Facing East \\
\hline & & 83 & Inside Facing South \\
\hline & & 84 & Inside Facing West \\
\hline & & 85 & Outside Facing North \\
\hline & & 86 & Outside Facing East \\
\hline & & 87 & Outside Facing South \\
\hline & & 88 & Outside Facing West \\
\hline \multirow{36}{*}{111} & \multirow{9}{*}{$12 / 18 / 2012$} & 89 & Lower North Cover Facing North \\
\hline & & 90 & Lower North Cover Facing East \\
\hline & & 91 & South Cover Facing East \\
\hline & & 92 & Upper North Cover Facing East \\
\hline & & 93 & Upper North Cover Facing South \\
\hline & & 94 & West Cover Facing North \\
\hline & & 95 & South Cover Facing North \\
\hline & & 96 & South Cover Facing Northwest \\
\hline & & 97 & Arizona Crossing Facing West \\
\hline & \multirow{9}{*}{$03 / 12 / 2013$} & 98 & Lower North Cover Facing North \\
\hline & & 99 & Lower North Cover Facing East \\
\hline & & 100 & South Cover Facing East \\
\hline & & 101 & Upper North Cover Facing East \\
\hline & & 102 & Upper North Cover Facing South \\
\hline & & 103 & West Cover Facing North \\
\hline & & 104 & South Cover Facing North \\
\hline & & 105 & South Cover Facing Northwest \\
\hline & & 106 & Arizona Crossing Facing West \\
\hline & \multirow{9}{*}{$06 / 18 / 2013$} & 107 & Lower North Cover Facing North \\
\hline & & 108 & Lower North Cover Facing East \\
\hline & & 109 & South Cover Facing East \\
\hline & & 110 & Upper North Cover Facing East \\
\hline & & 111 & Upper North Cover Facing South \\
\hline & & 112 & West Cover Facing North \\
\hline & & 113 & South Cover Facing North \\
\hline & & 114 & South Cover Facing Northwest \\
\hline & & 115 & Arizona Crossing Facing West \\
\hline & \multirow{9}{*}{$09 / 17 / 2013$} & 116 & L Lower North Cover Facing North \\
\hline & & 117 & Lower North Cover Facing East \\
\hline & & 118 & South Cover Facing East \\
\hline & & 119 & Upper North Cover Facing East \\
\hline & & 120 & Upper North Cover Facing South \\
\hline & & 121 & West Cover Facing North \\
\hline & & 122 & South Cover Facing North \\
\hline & & 123 & South Cover Facing Northwest \\
\hline & & 124 & Arizona Crossing Facing West \\
\hline
\end{tabular}


RCRA Post-Closure Report

Revision: 0

Date: January 2014

THIS PAGE INTENTIONALLY LEFT BLANK 


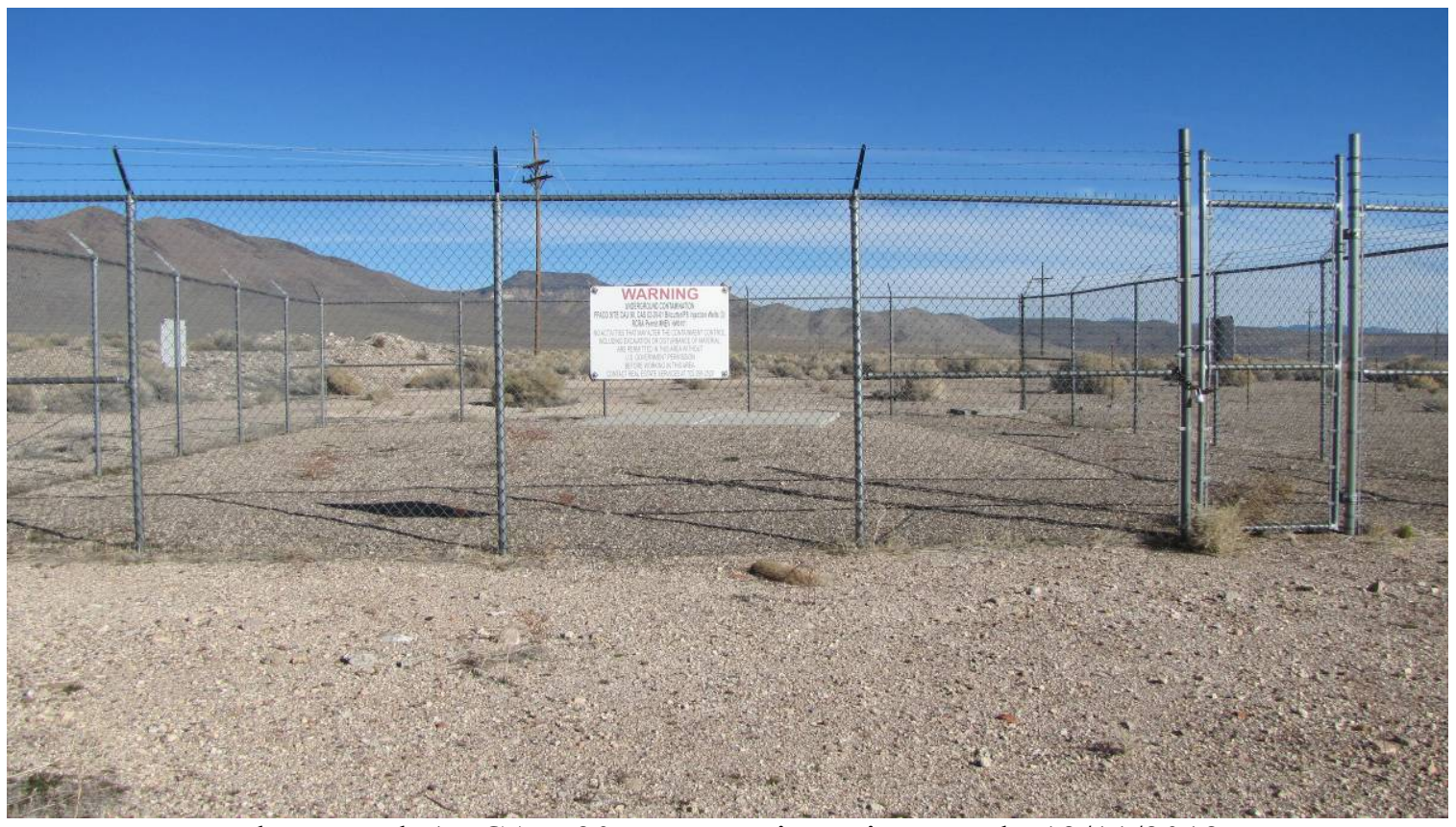

Photograph 1: CAU 90, West Unit Facing North, 12/11/2012

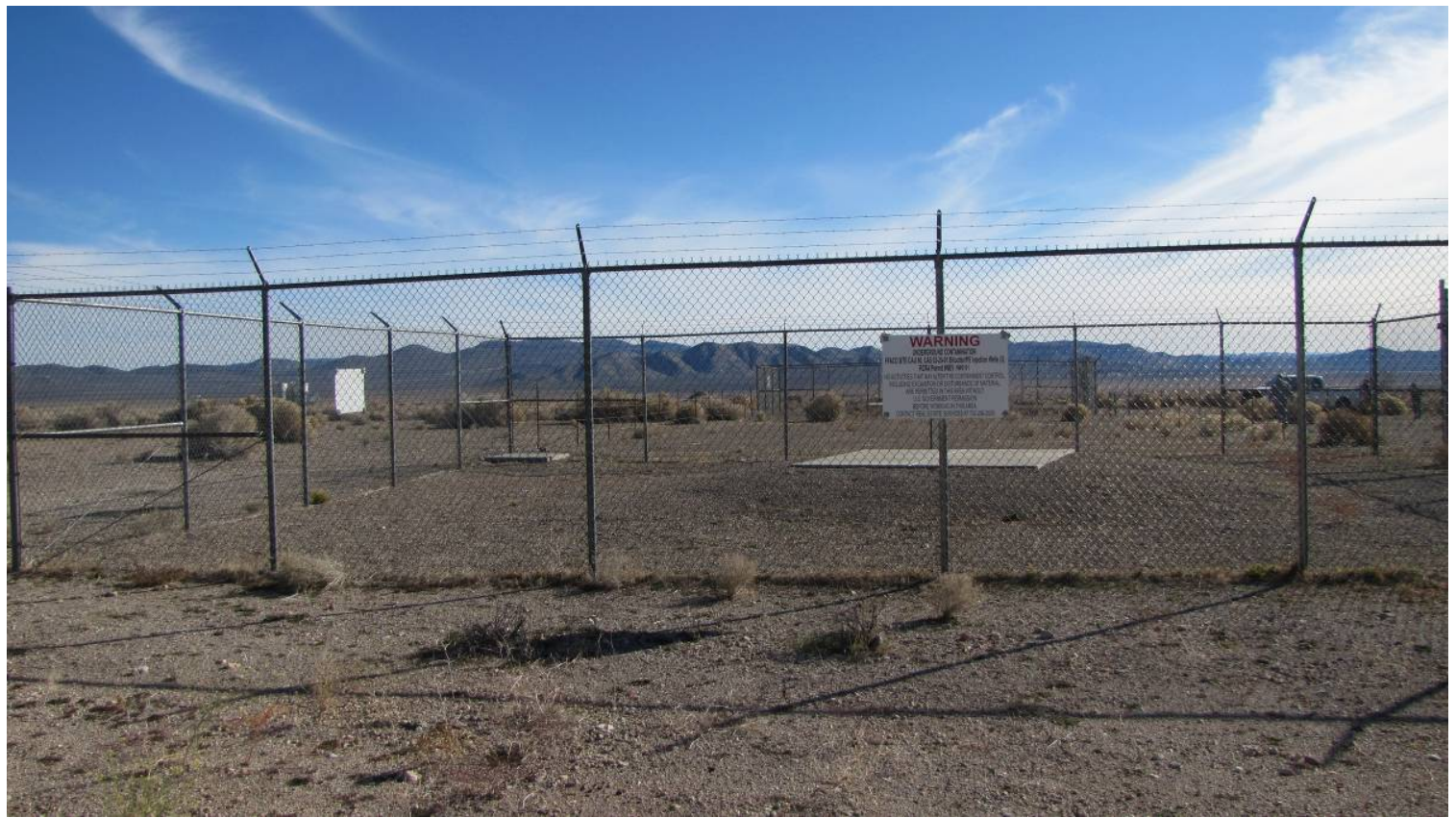

Photograph 2: CAU 90, West Unit Facing East, 12/11/2012 


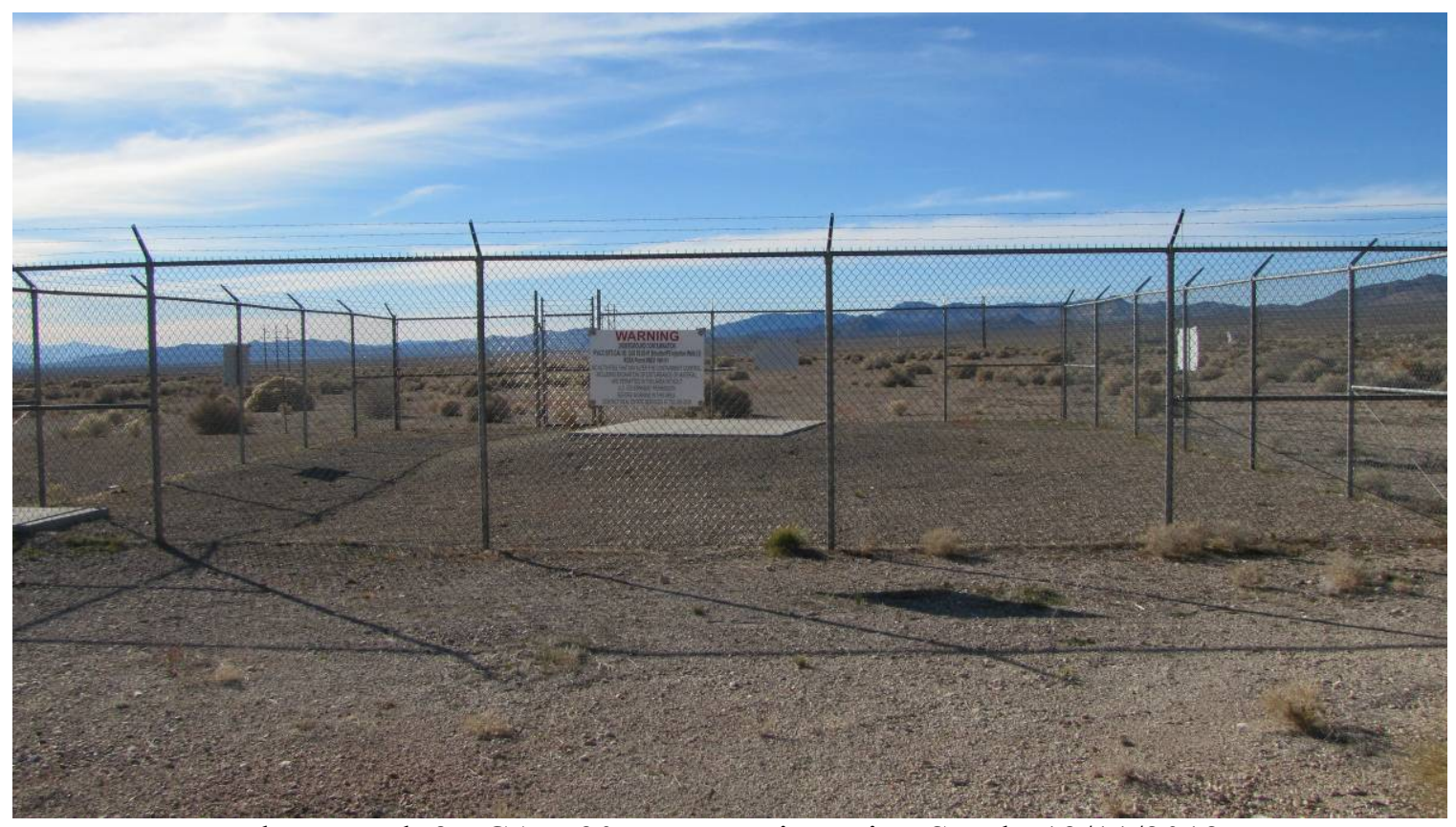

Photograph 3: CAU 90, West Unit Facing South, 12/11/2012

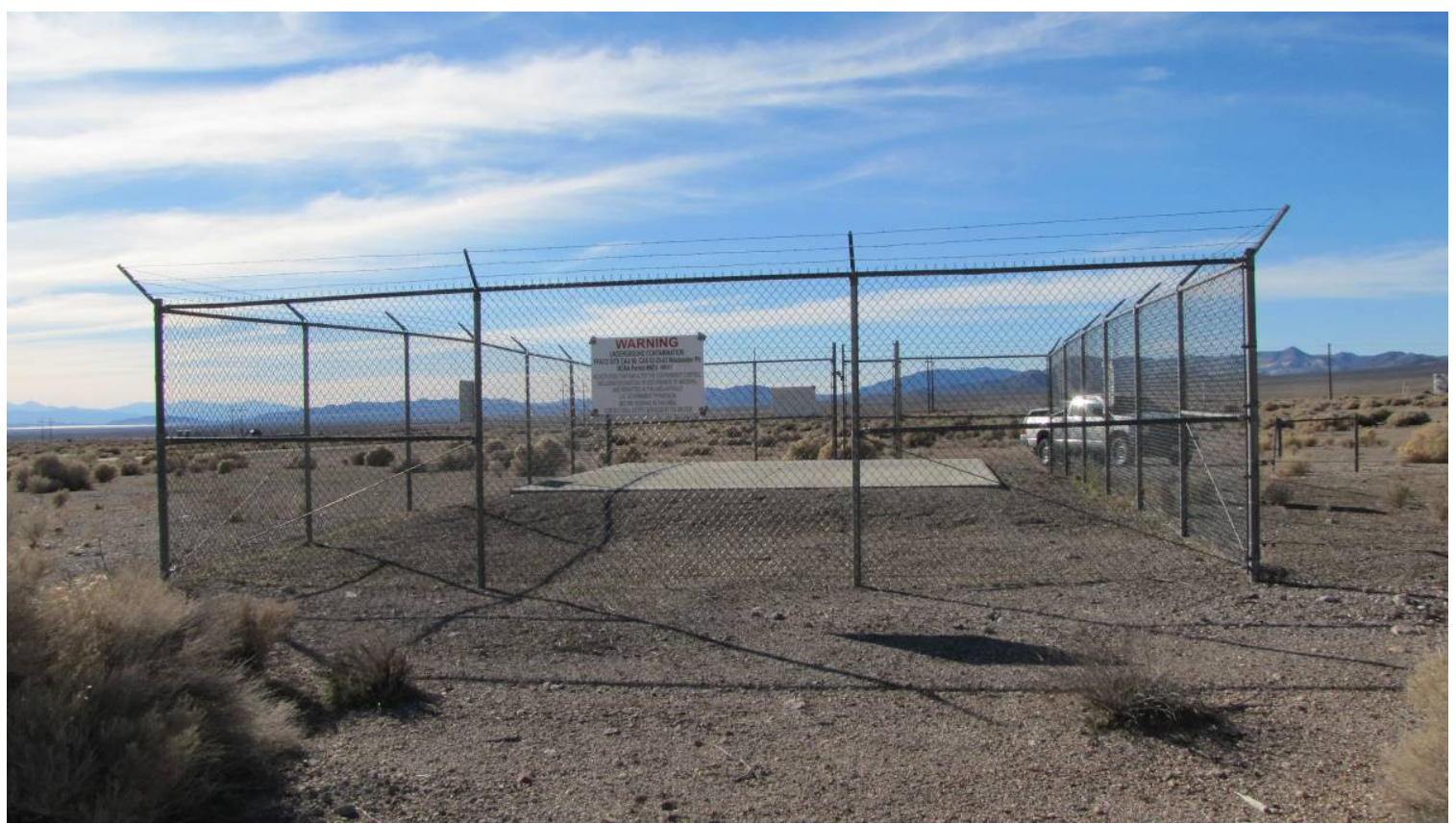

Photograph 4: CAU 90, East Unit Facing South, 12/11/2012 


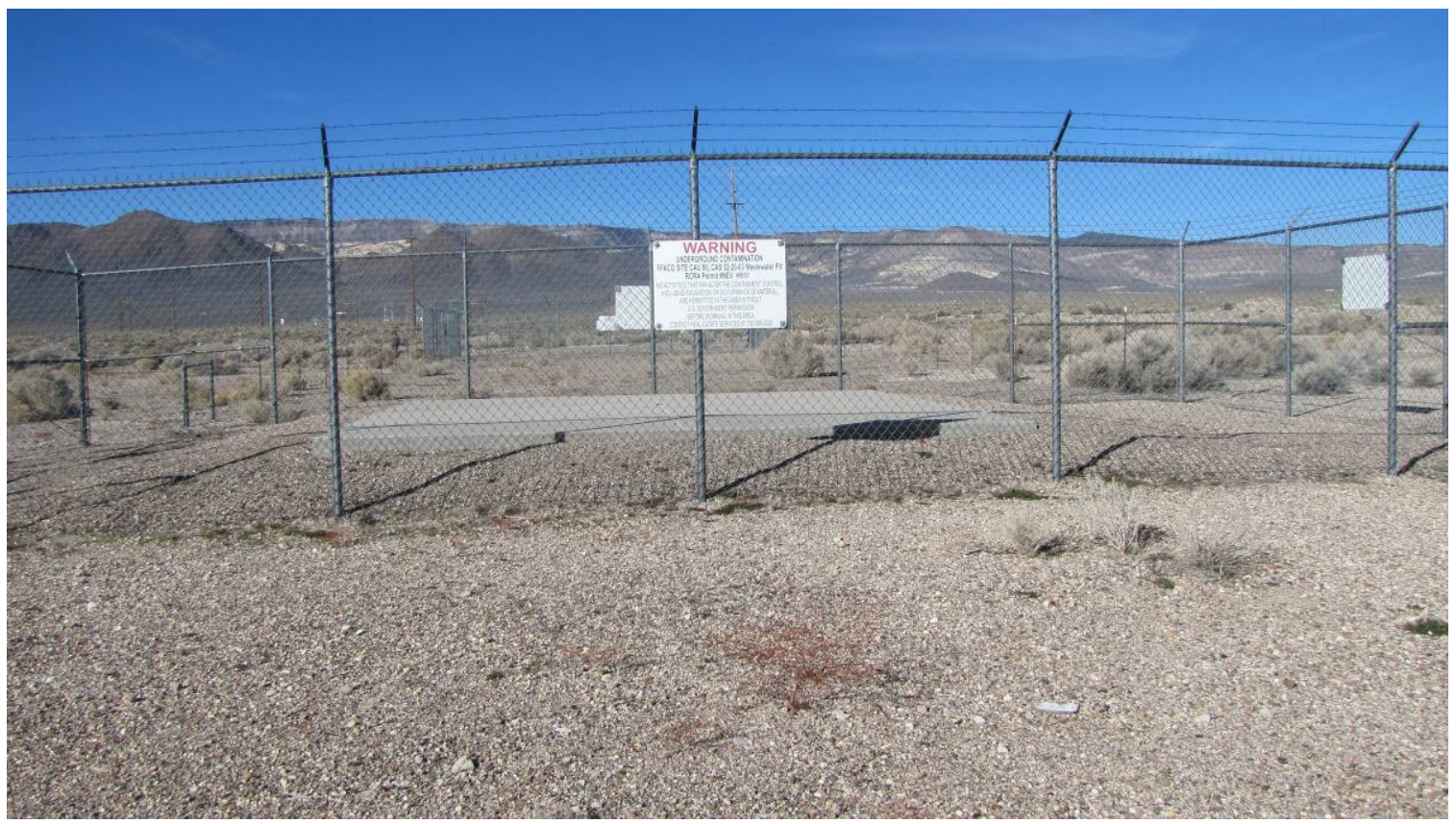

Photograph 5: CAU 90, East Unit Facing West, 12/11/2012

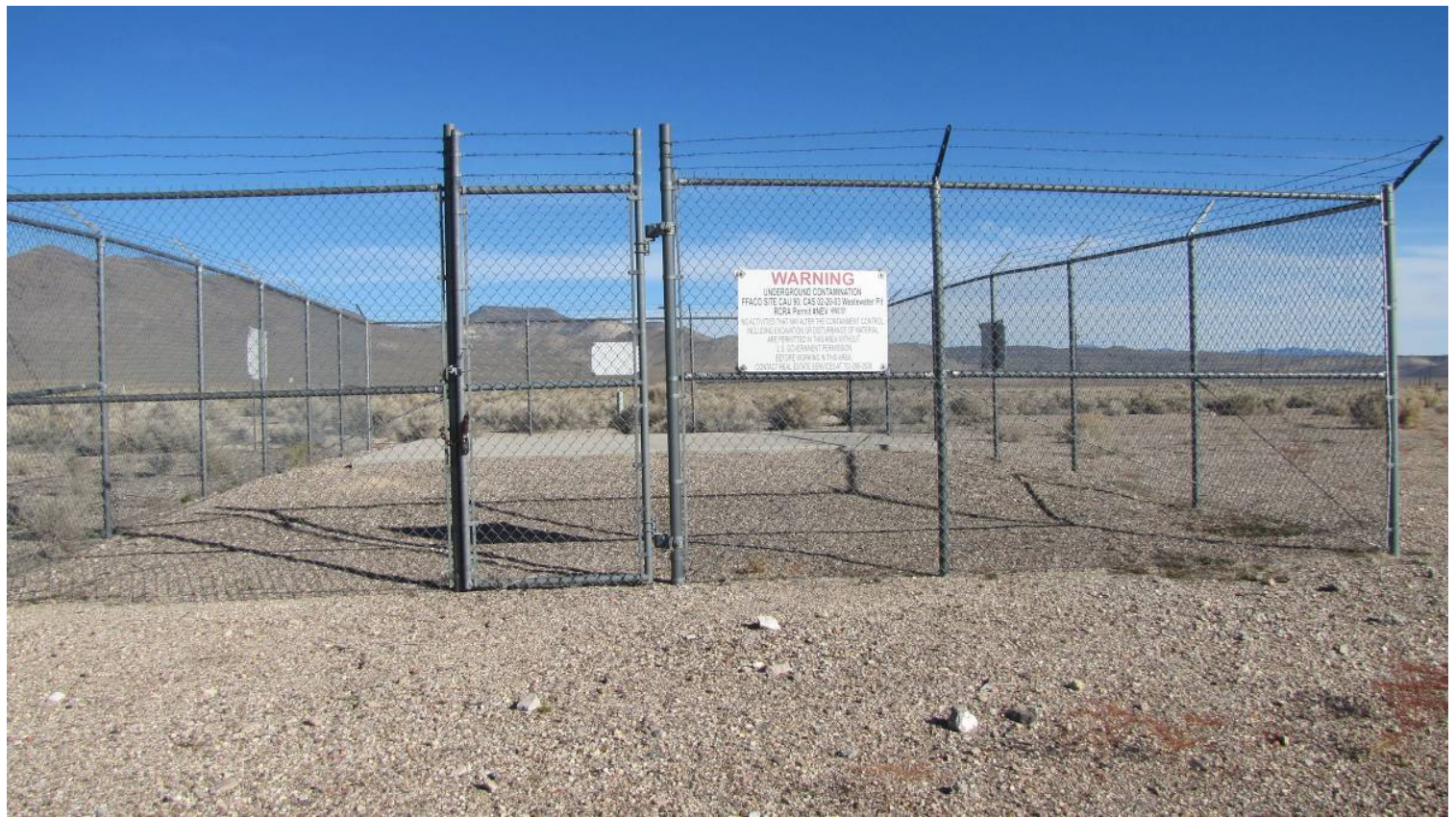

Photograph 6: CAU 90, East Unit Facing North, 12/11/2012 


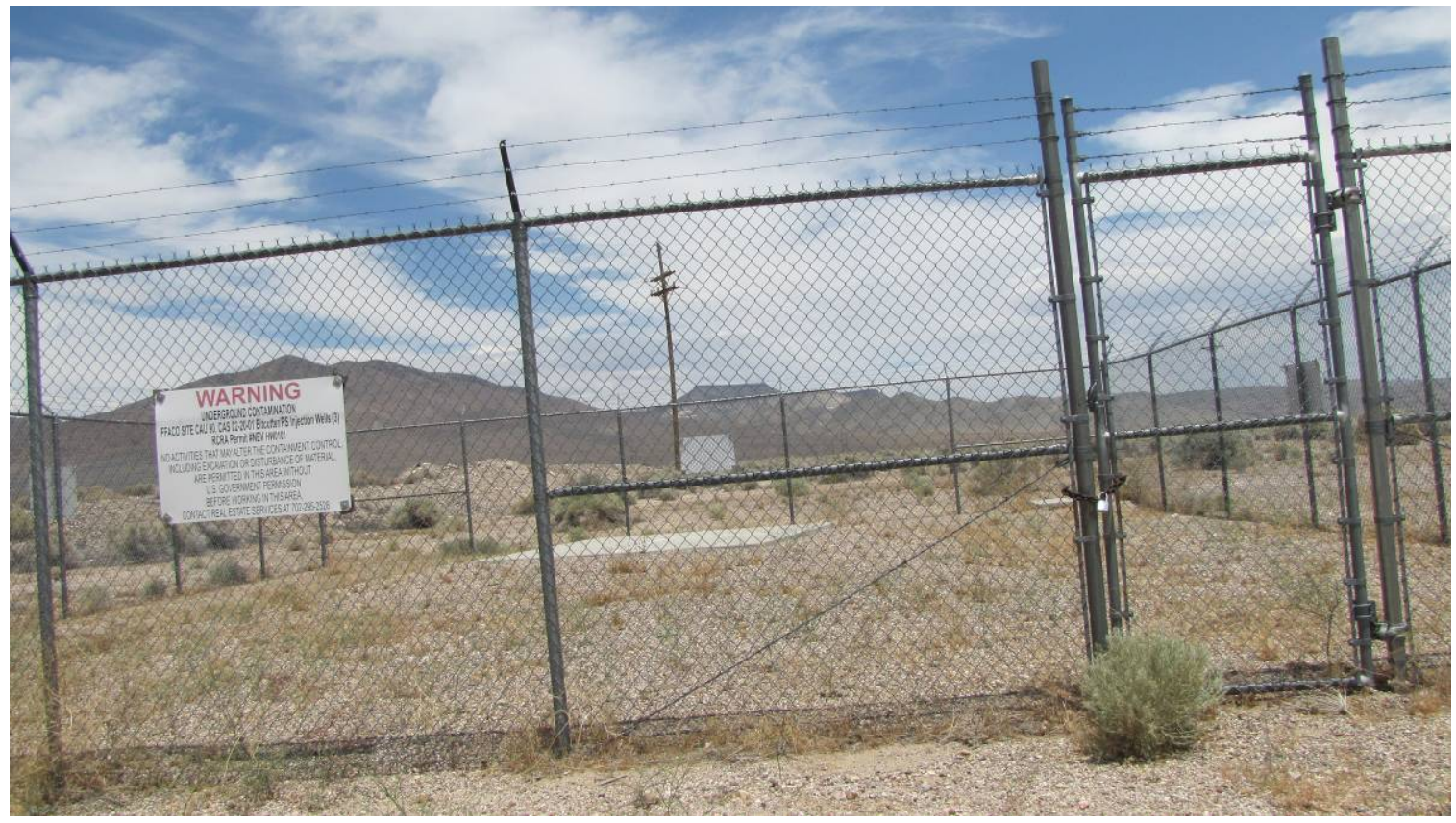

Photograph 7: CAU 90, West Unit Facing North, 06/12/2013

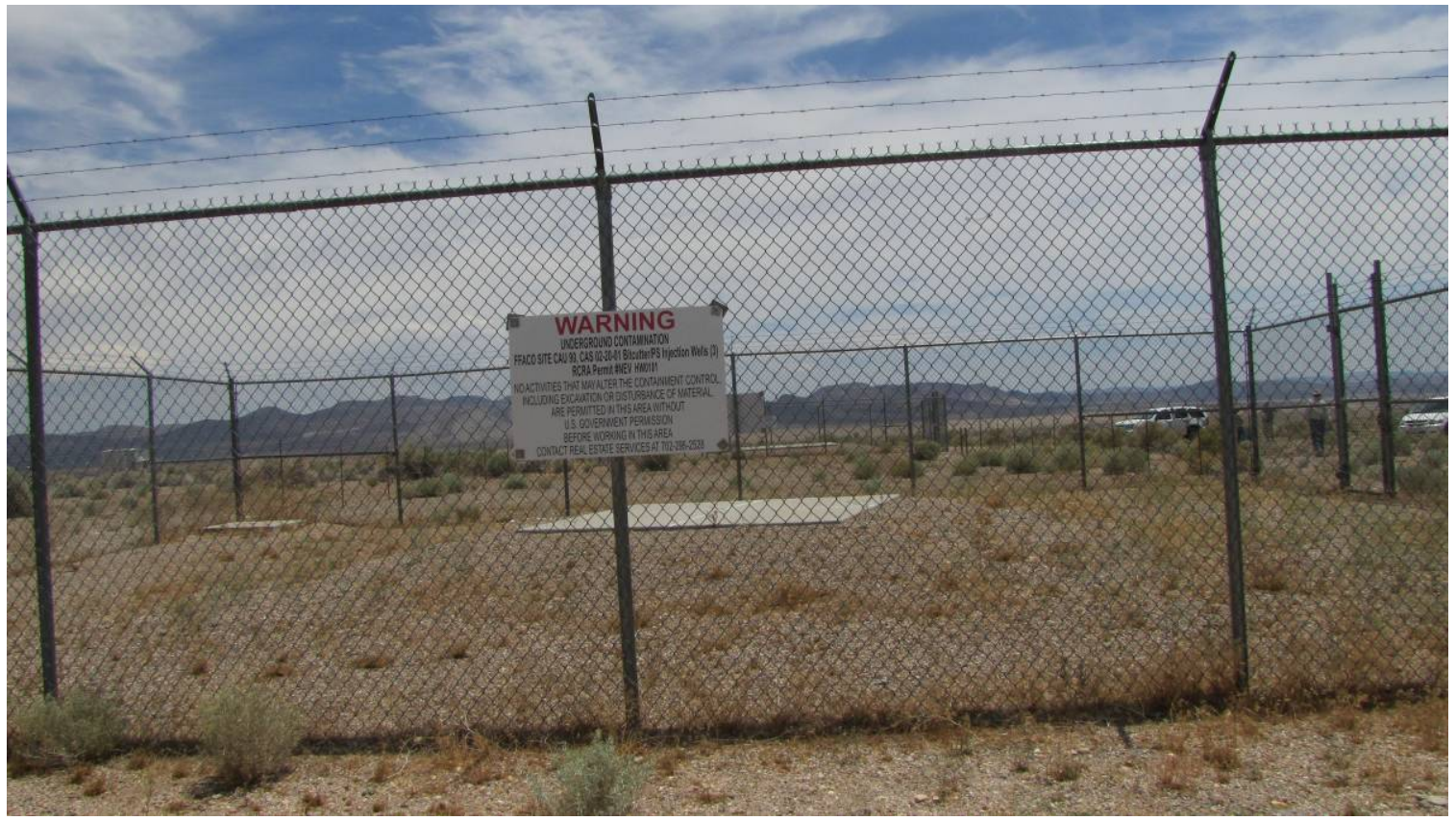

Photograph 8: CAU 90, West Unit Facing East, 06/12/2013 


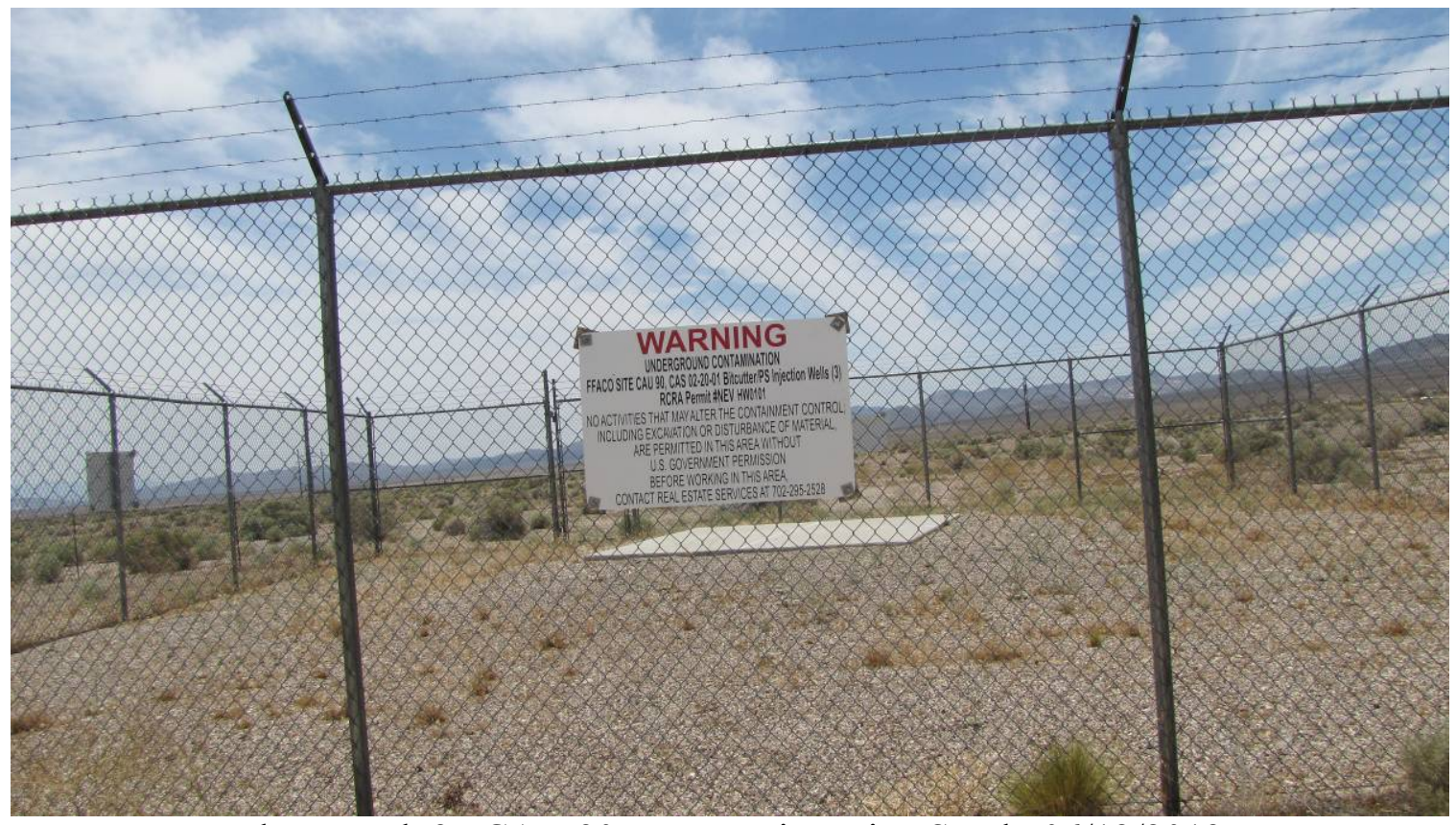

Photograph 9: CAU 90, West Unit Facing South, 06/12/2013

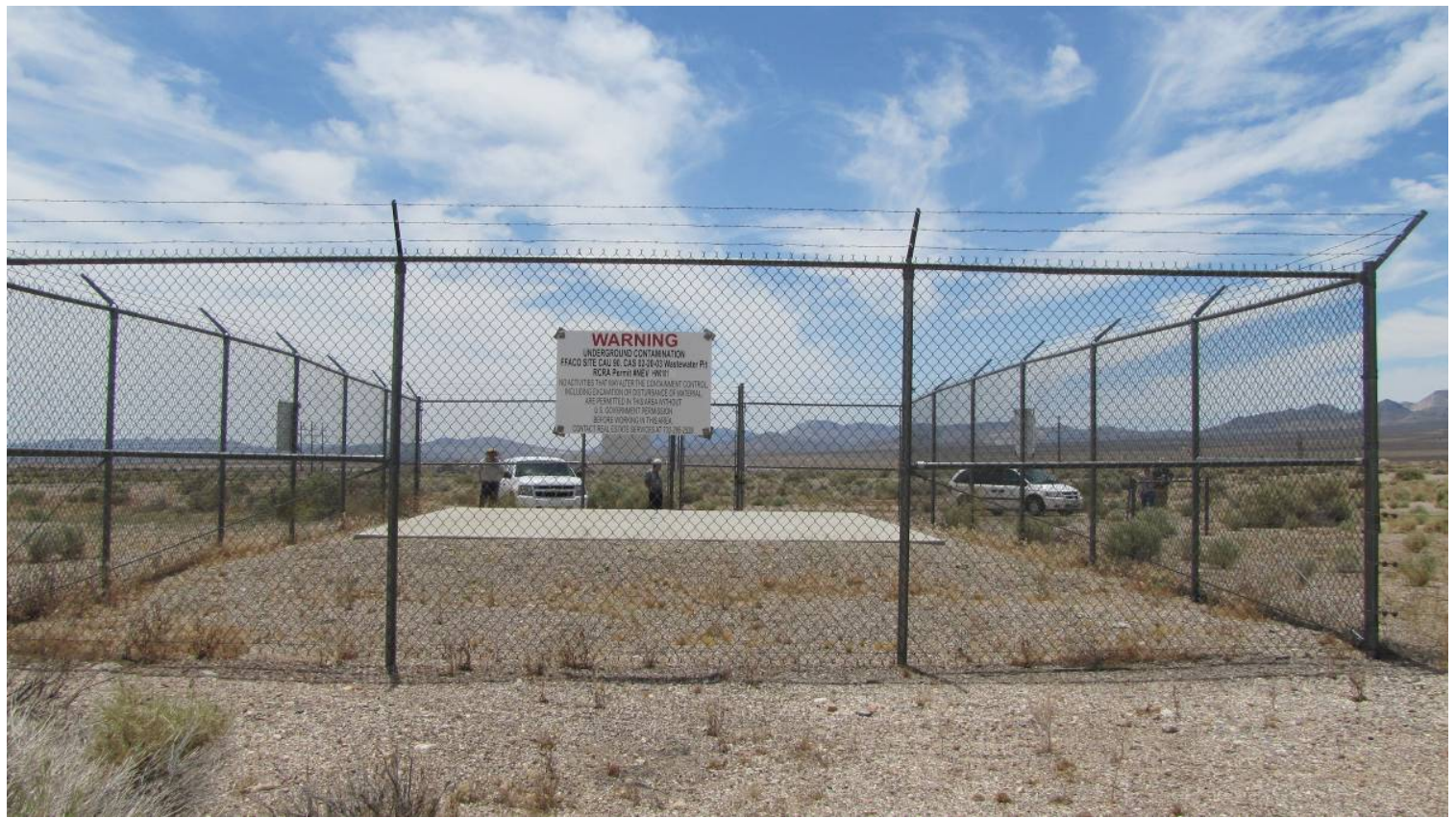

Photograph 10: CAU 90, East Unit Facing South, 06/12/2013 


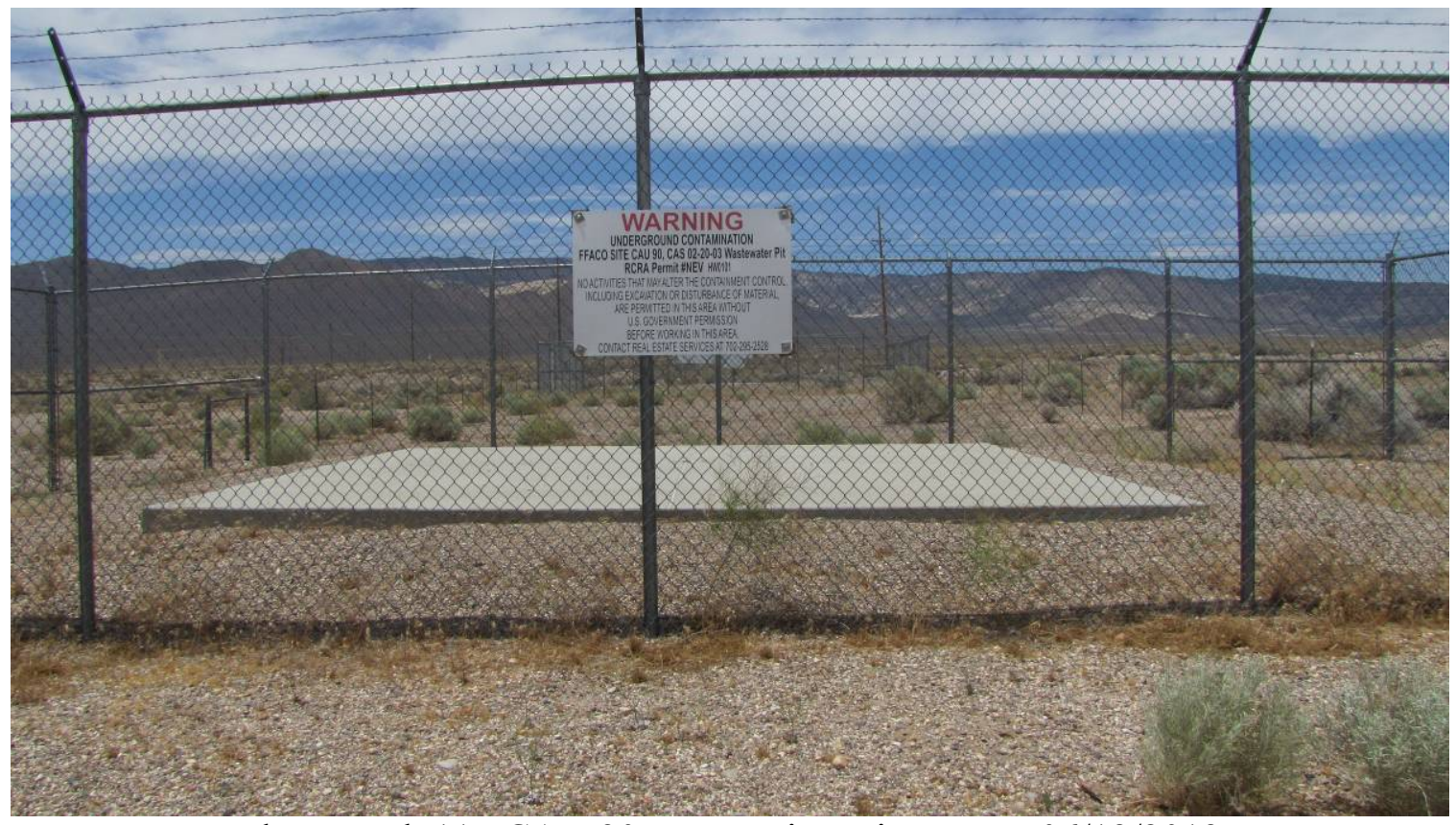

Photograph 11: CAU 90, East Unit Facing West, 06/12/2013

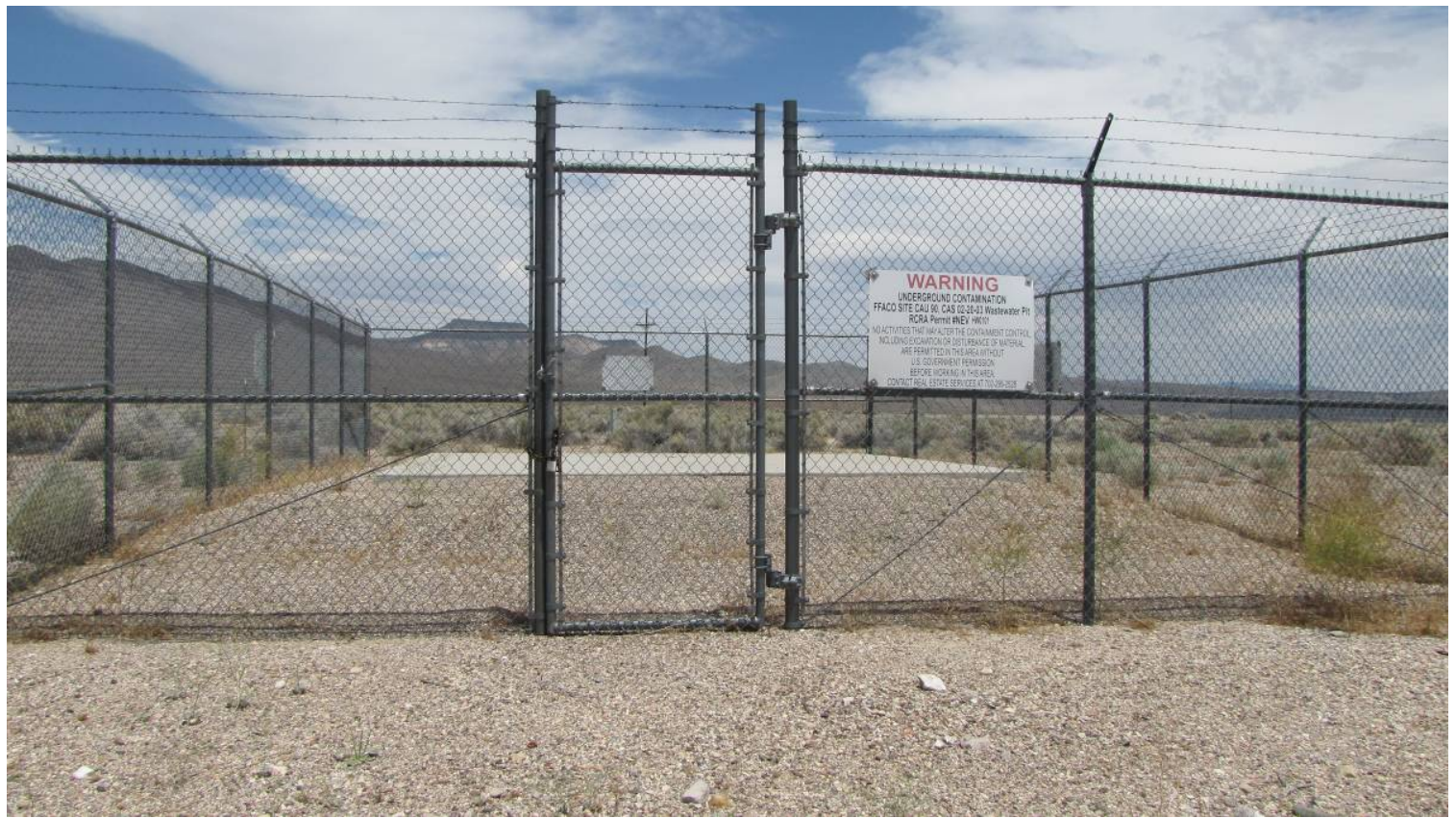

Photograph 12: CAU 90, East Unit Facing North, 06/12/2013 


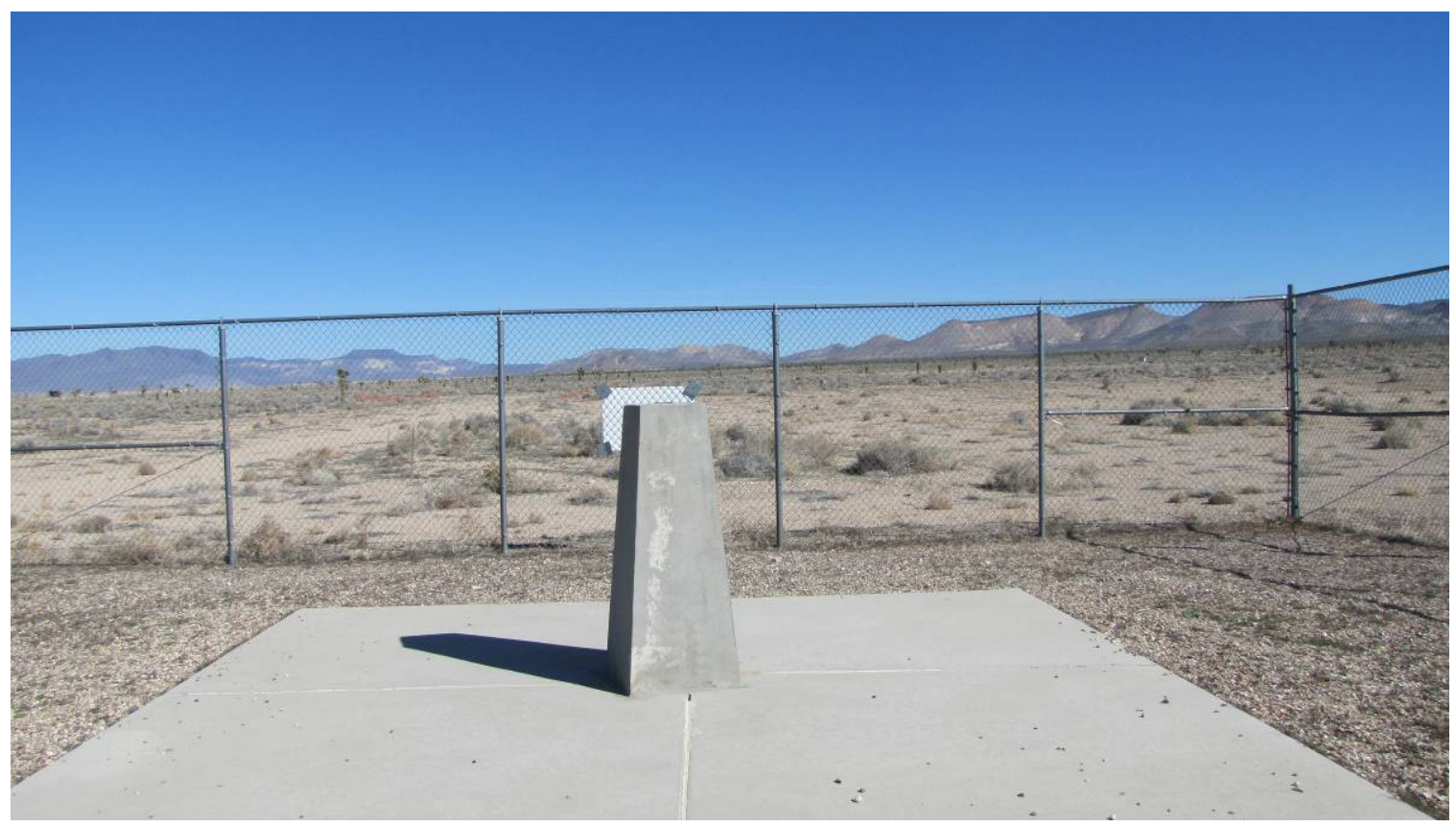

Photograph 13: CAU 91, Inside Facing North, 03/12/2013

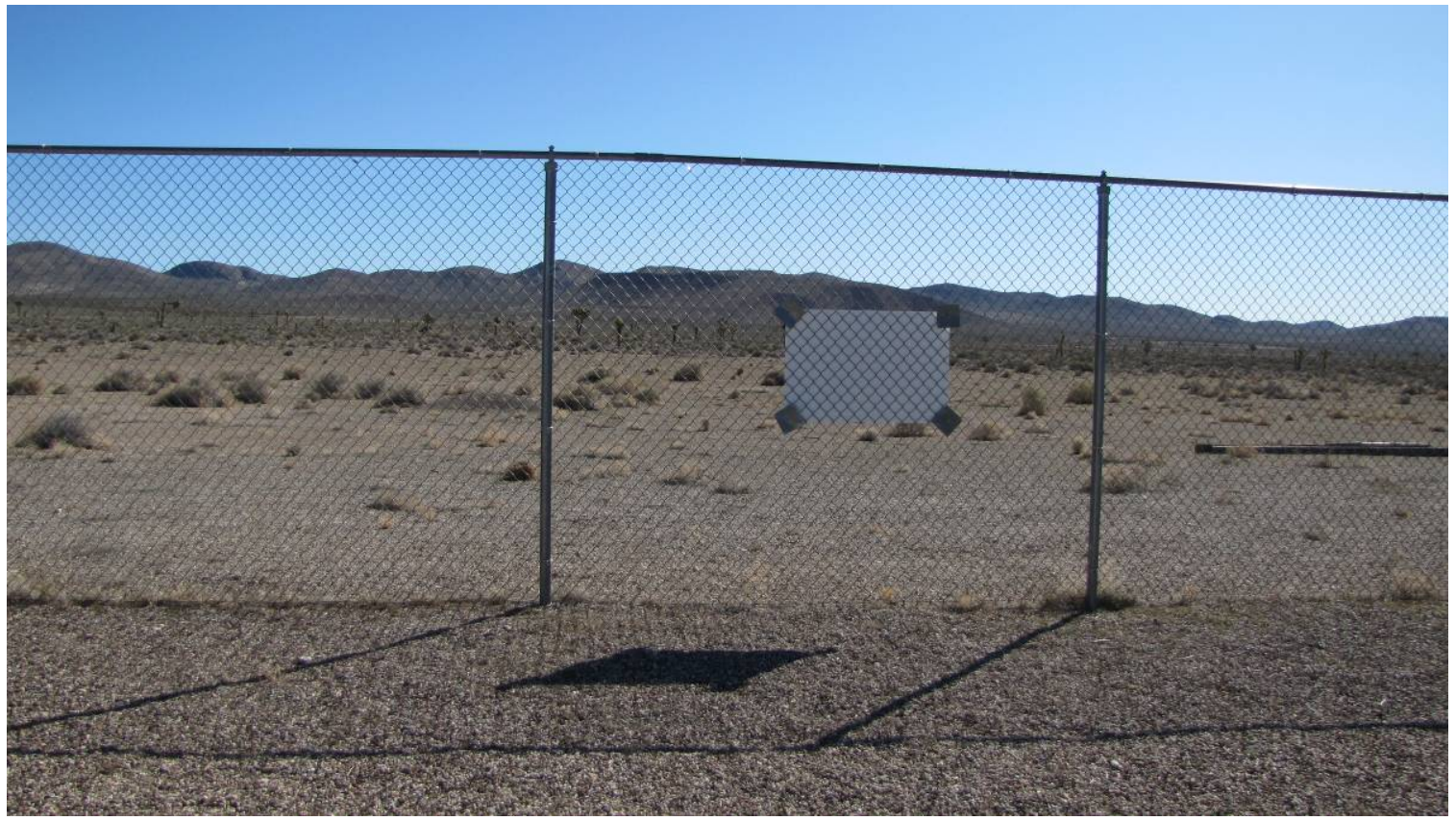

Photograph 14: CAU 91, Inside Facing East, 03/12/2013 


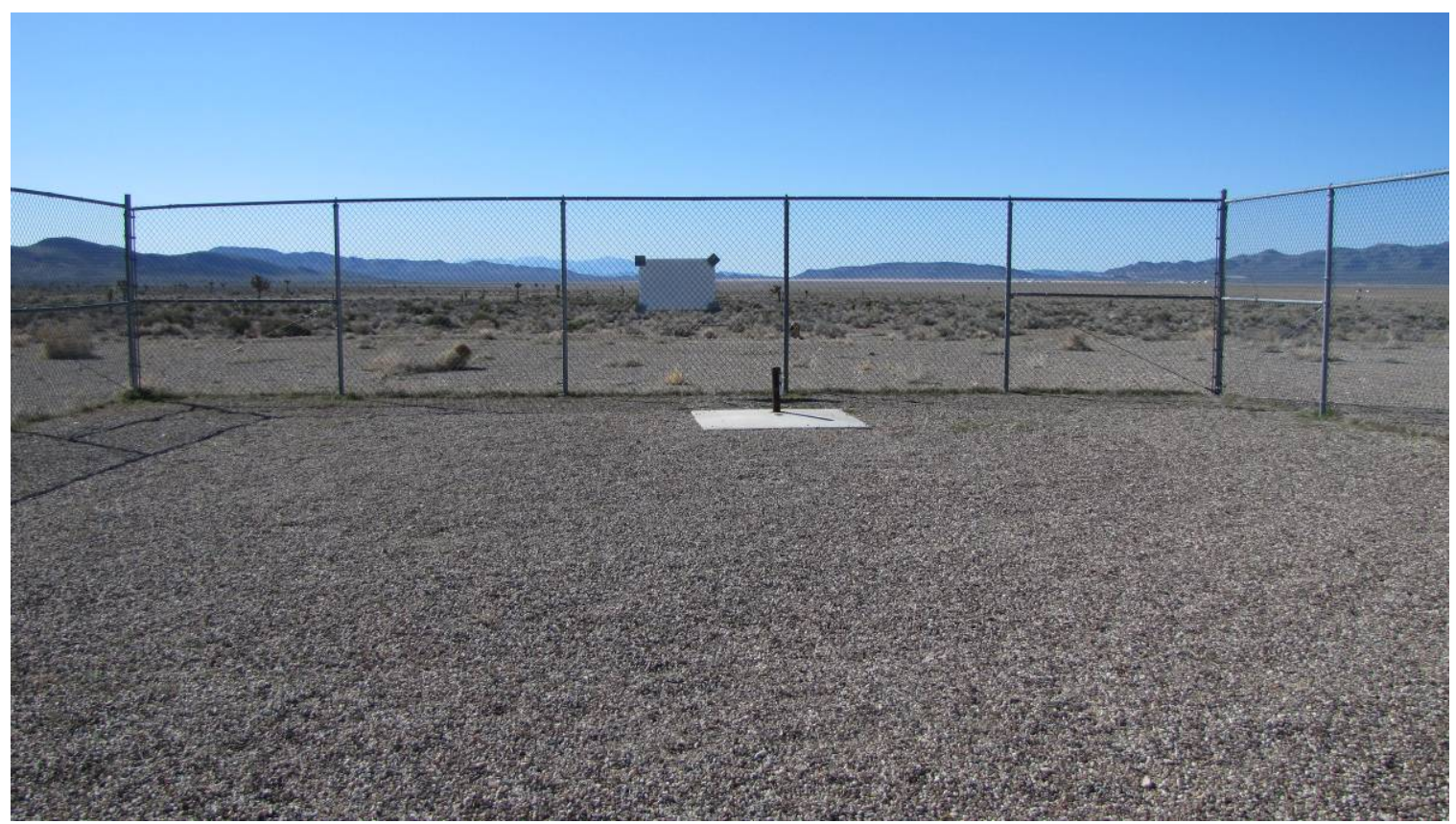

Photograph 15: CAU 91, Inside Facing South, 03/12/2013

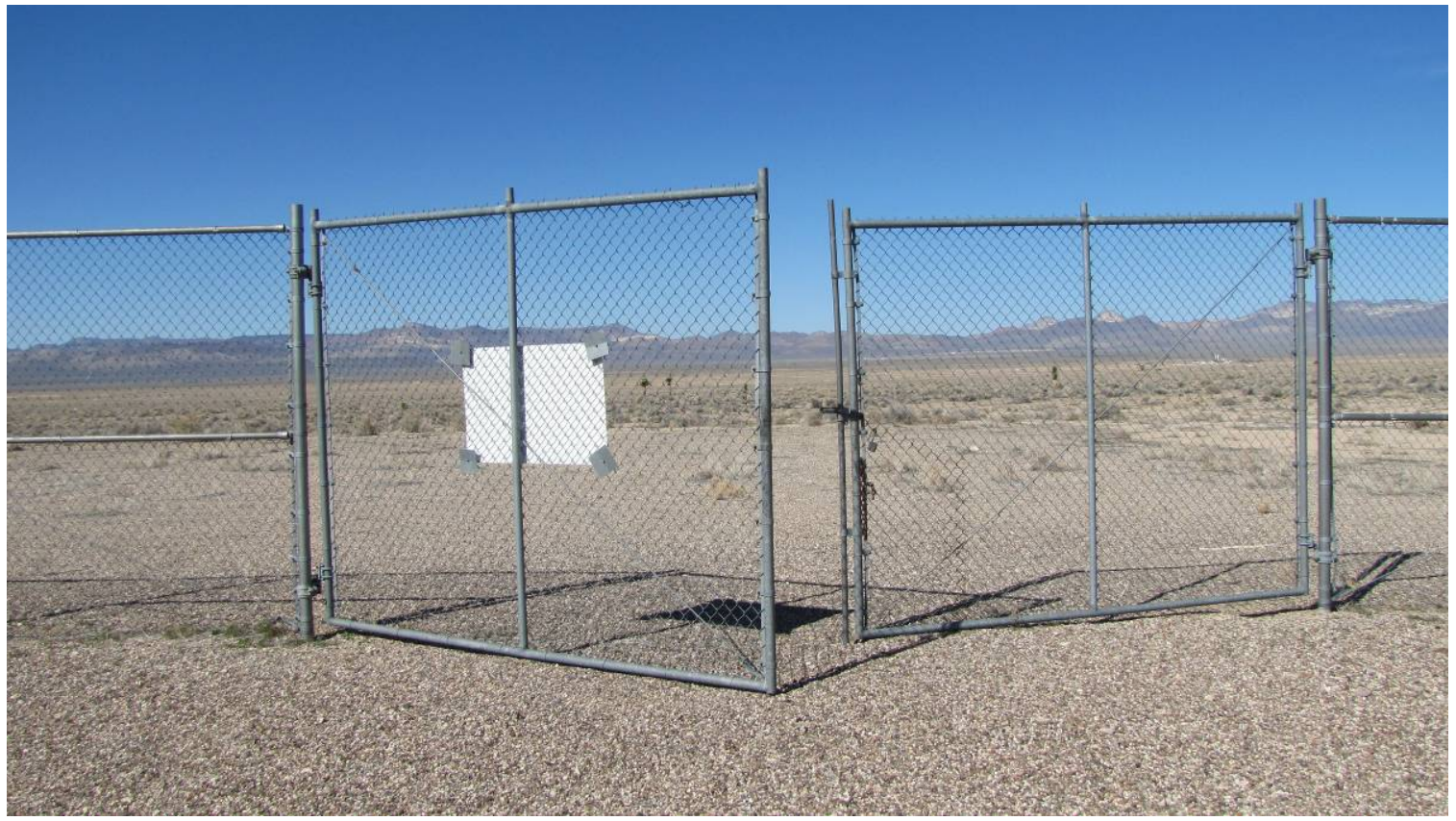

Photograph 16: CAU 91, Inside Facing West, 03/12/2013 


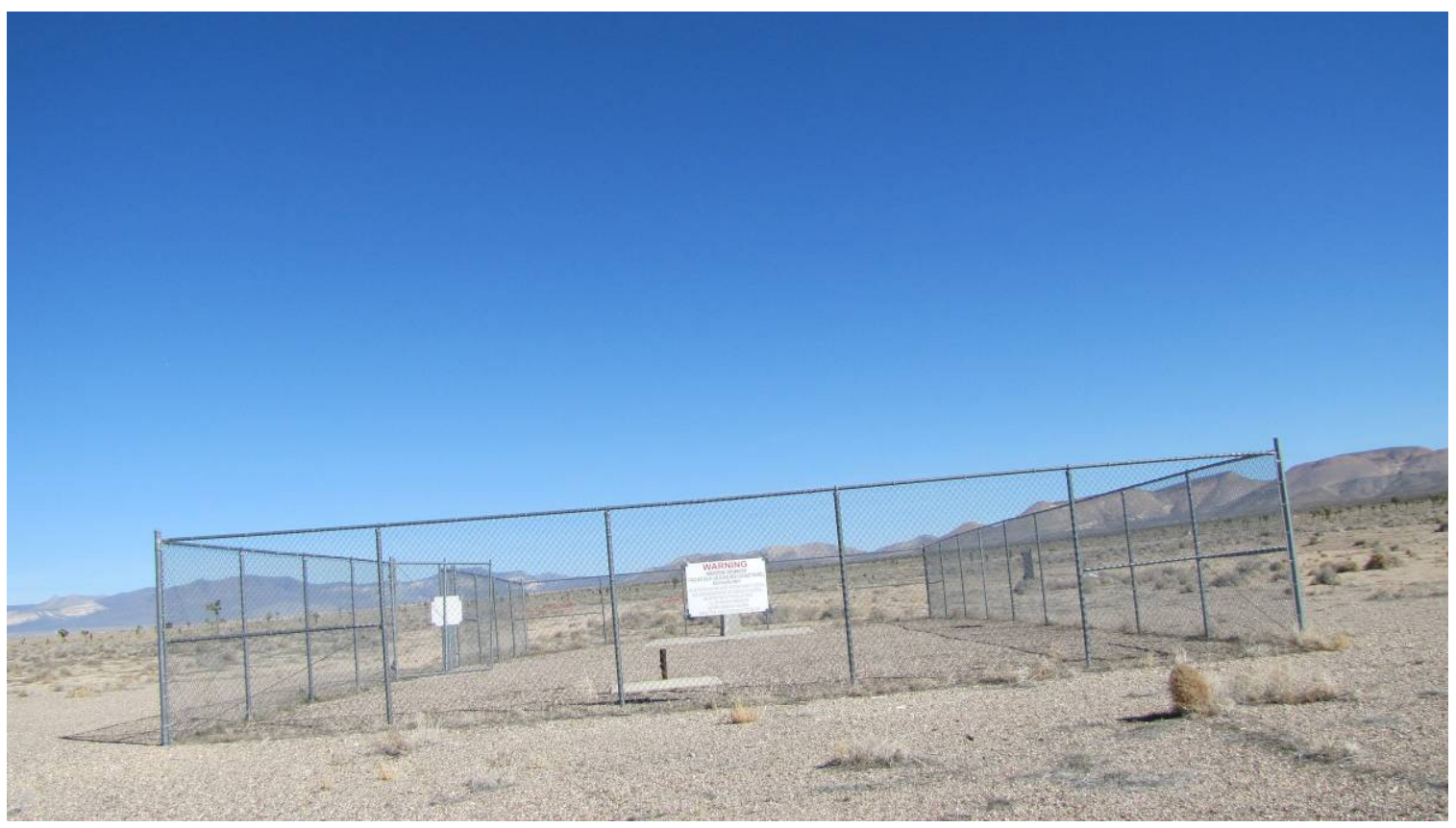

Photograph 17: CAU 91, Outside Facing North, 03/12/2013

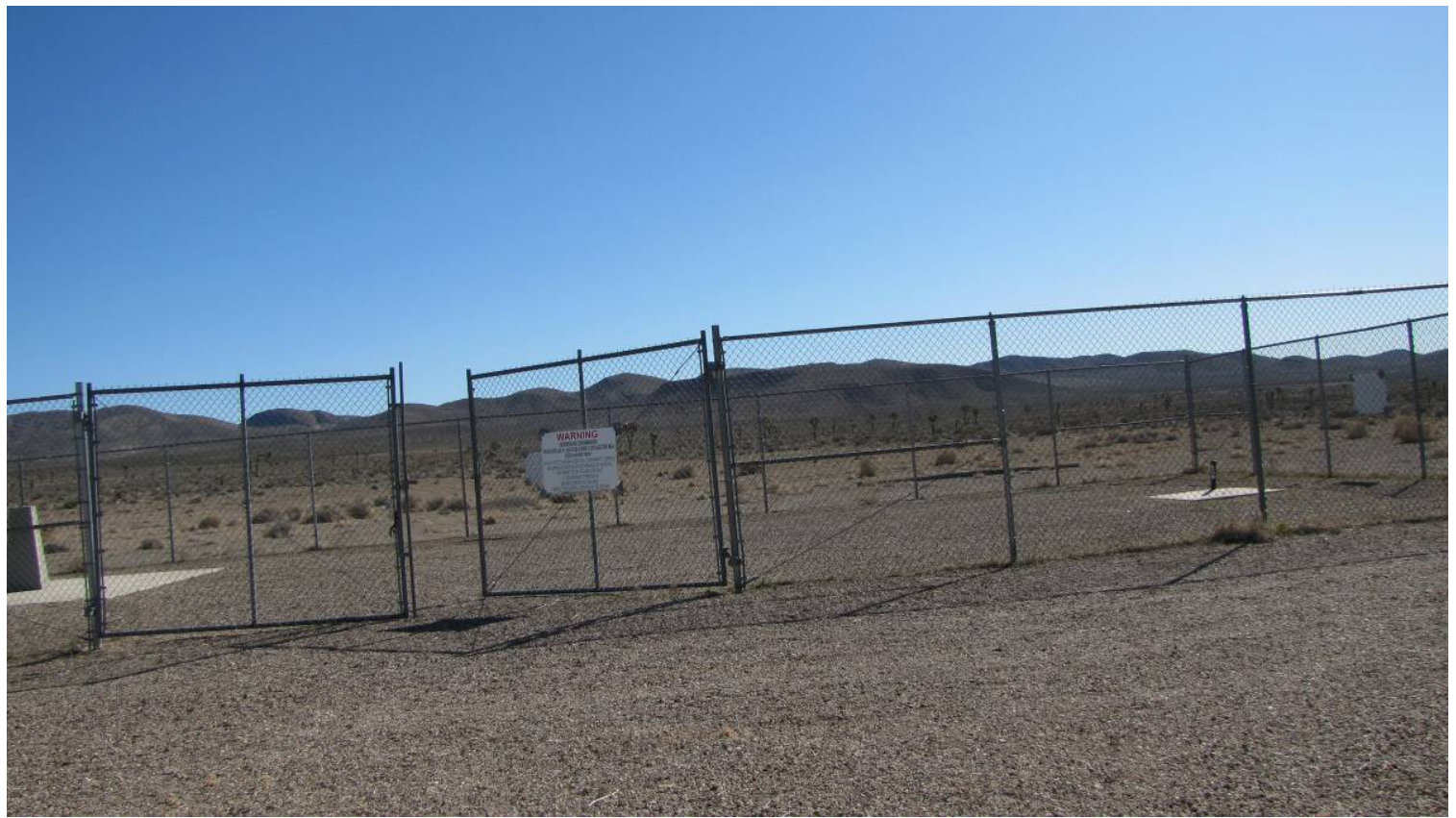

Photograph 18: CAU 91, Outside Facing East, 03/12/2013 


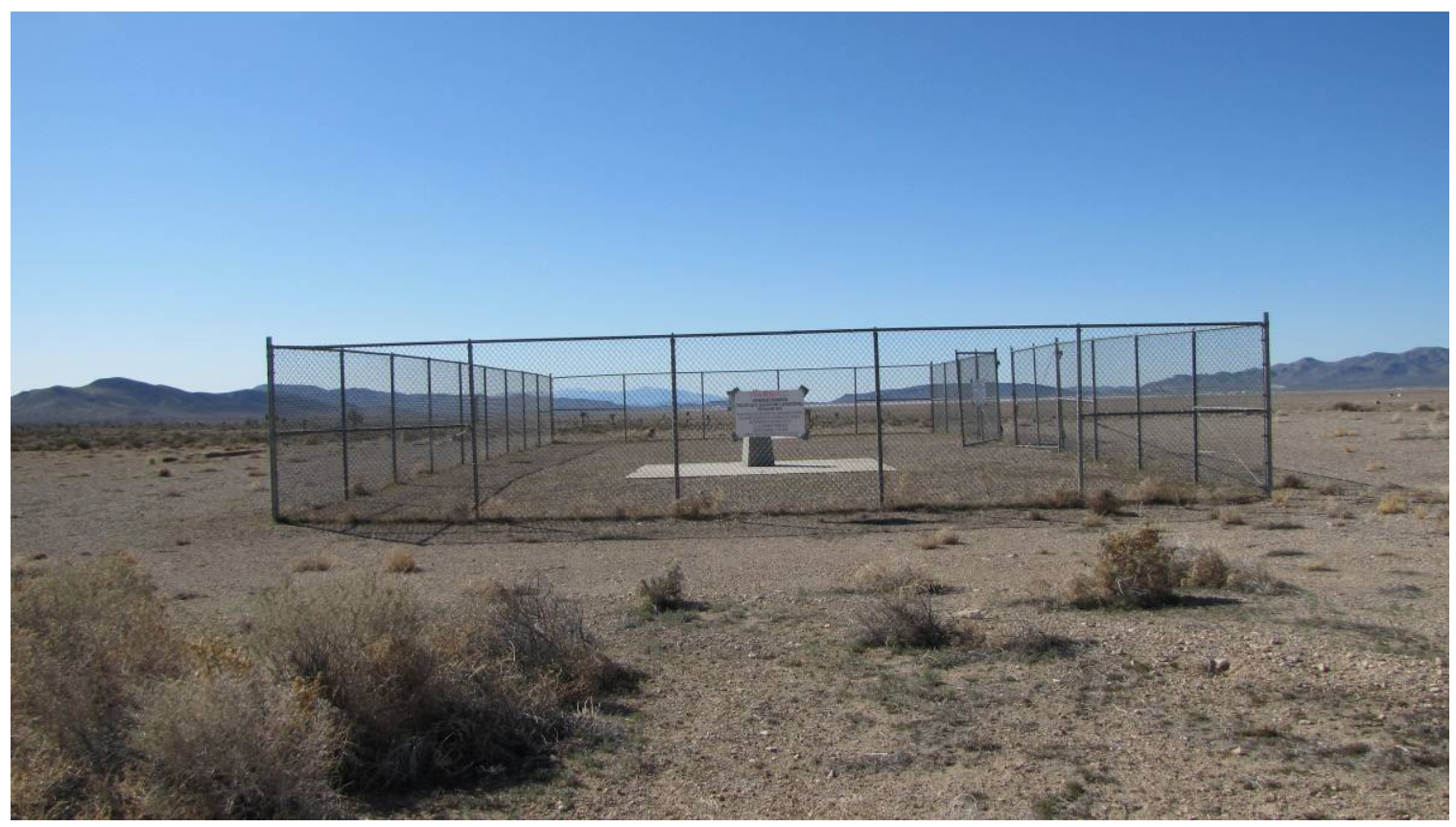

Photograph 19: CAU 91, Outside Facing South, 03/12/2013

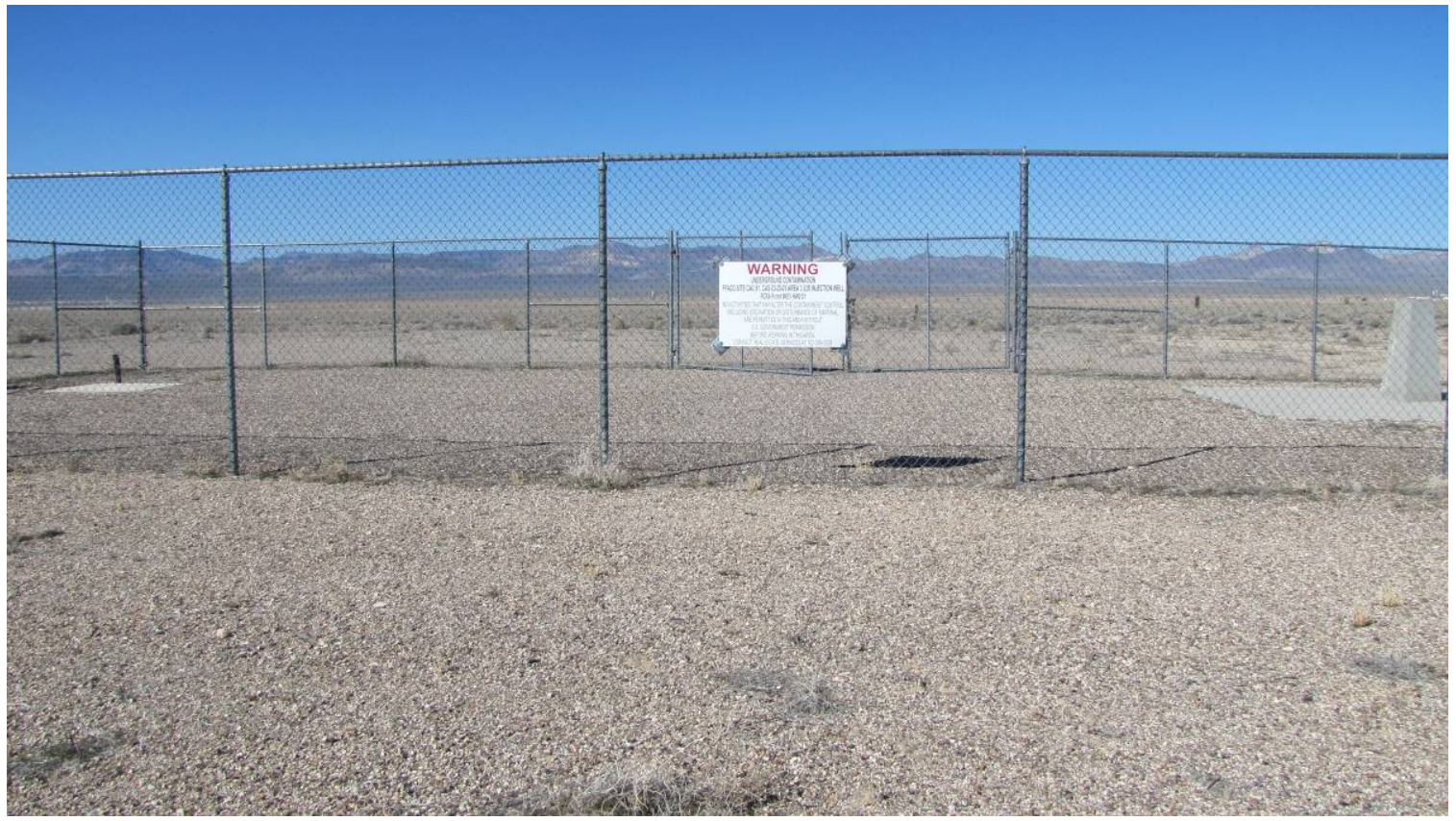

Photograph 20: CAU 91, Outside Facing West, 03/12/2013 


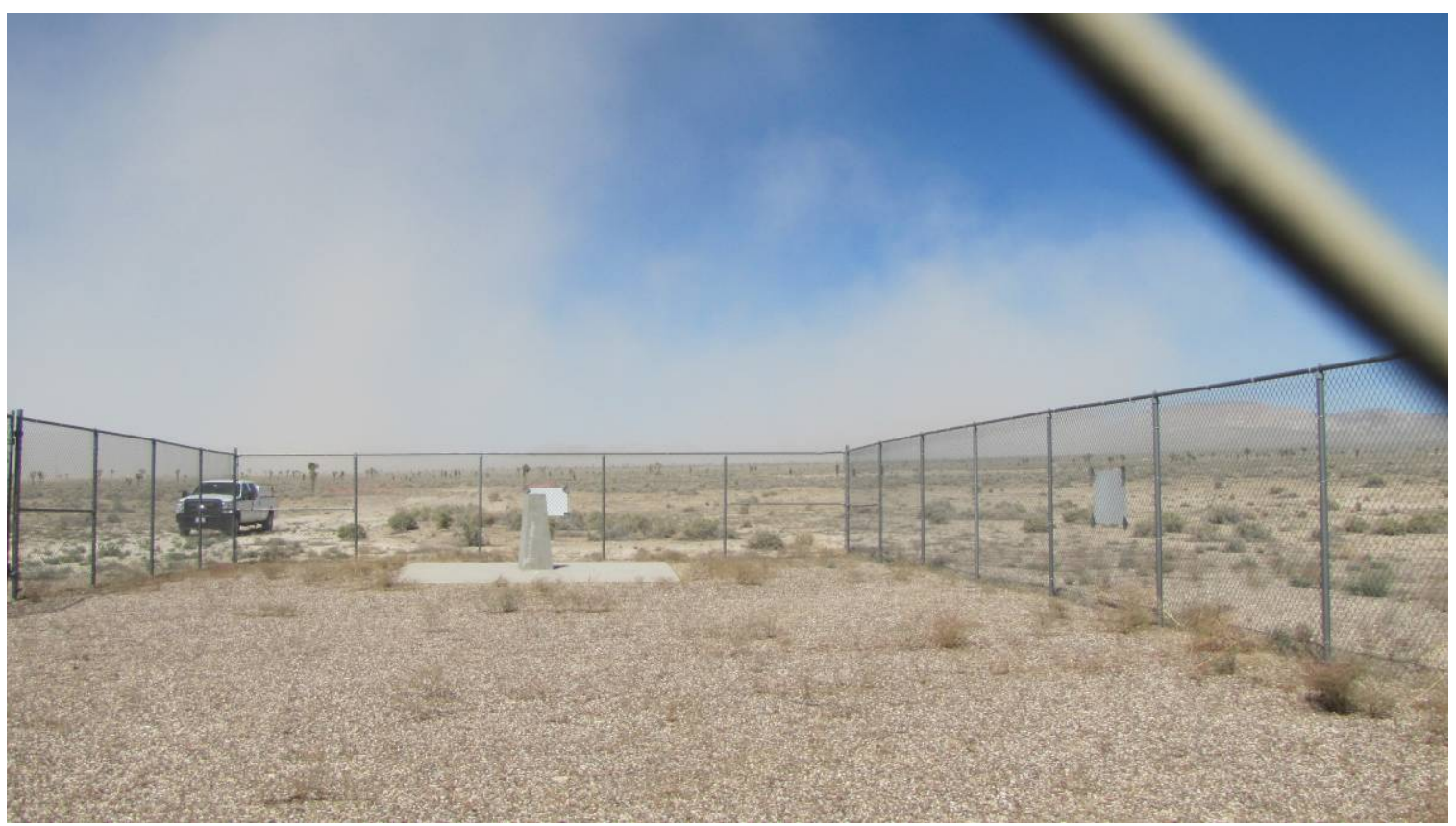

Photograph 21: CAU 91, Inside Facing North, 09/17/2013

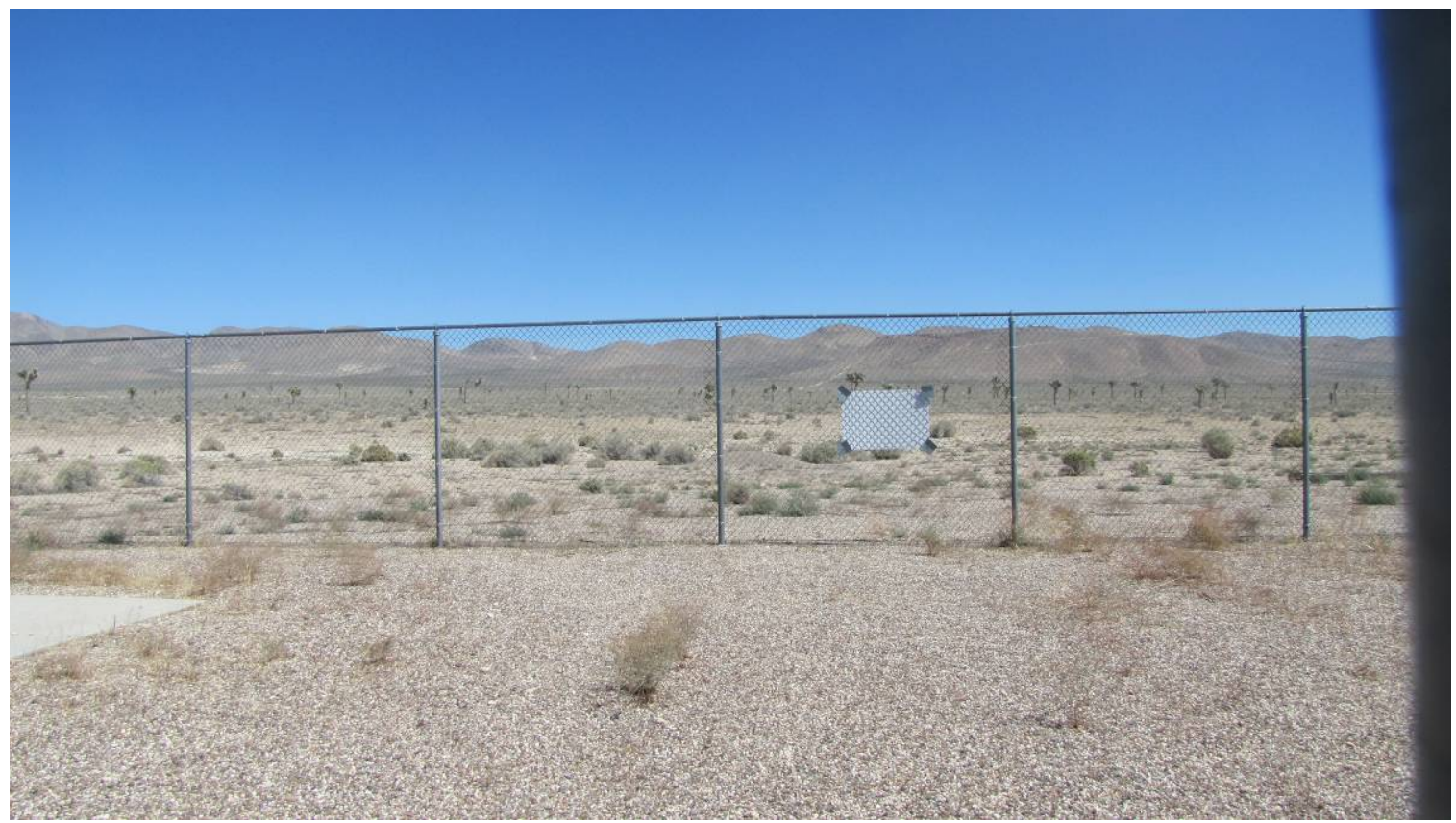

Photograph 22: CAU 91, Inside Facing East, 09/17/2013 


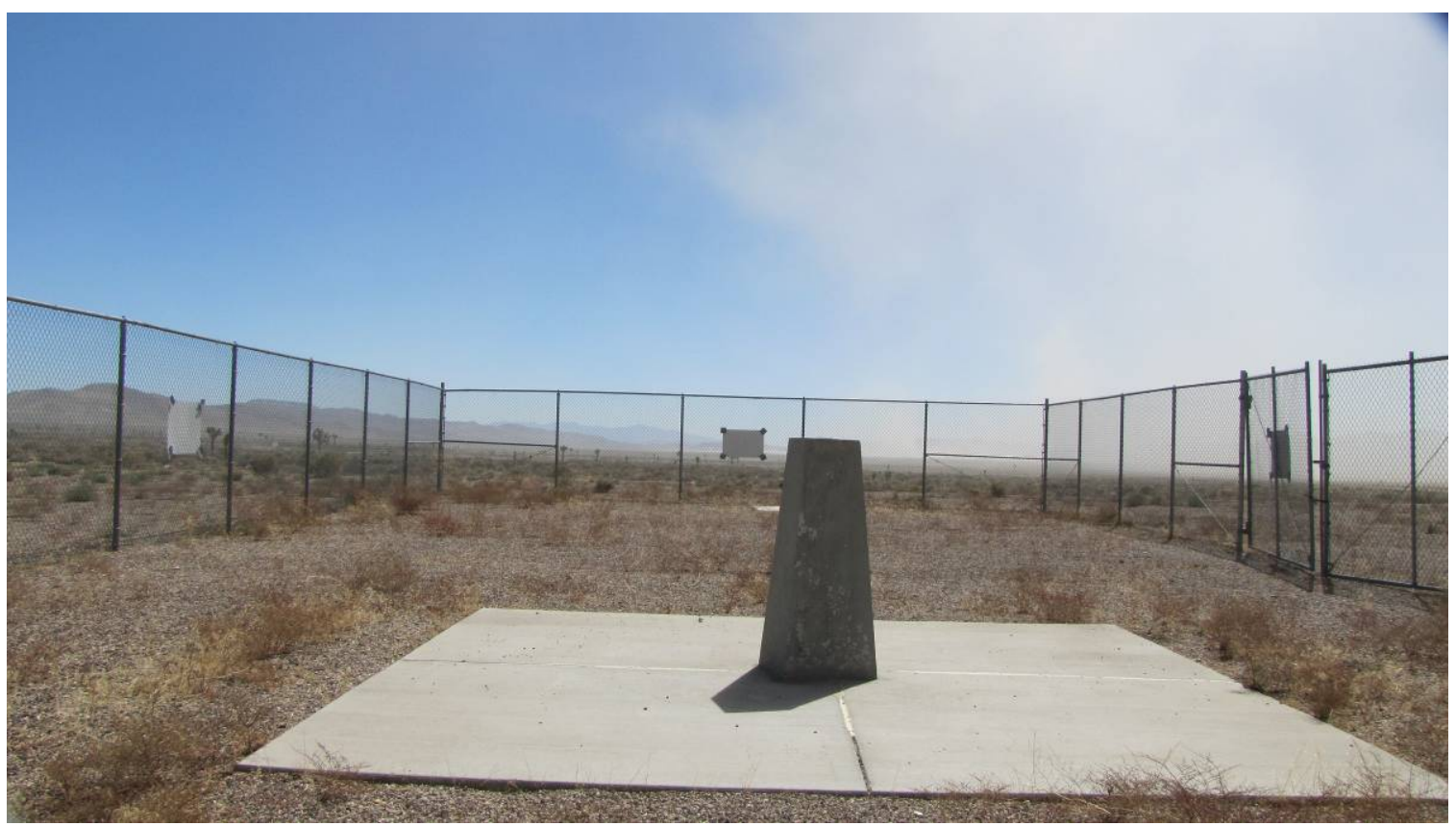

Photograph 23: CAU 91, Inside Facing South, 09/17/2013

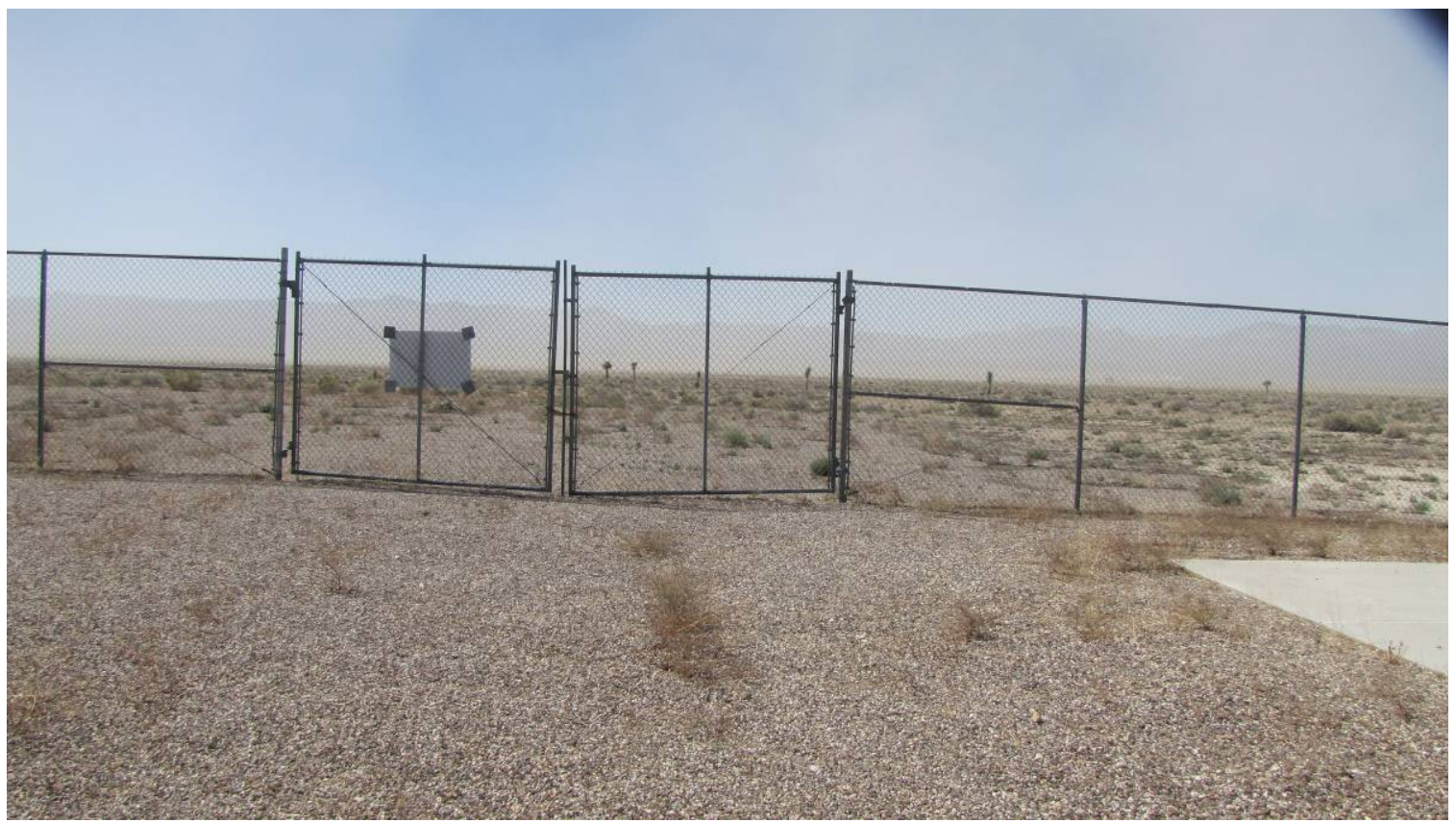

Photograph 24: CAU 91, Inside Facing West, 09/17/2013 
RCRA Post-Closure Report

Date: January 2014

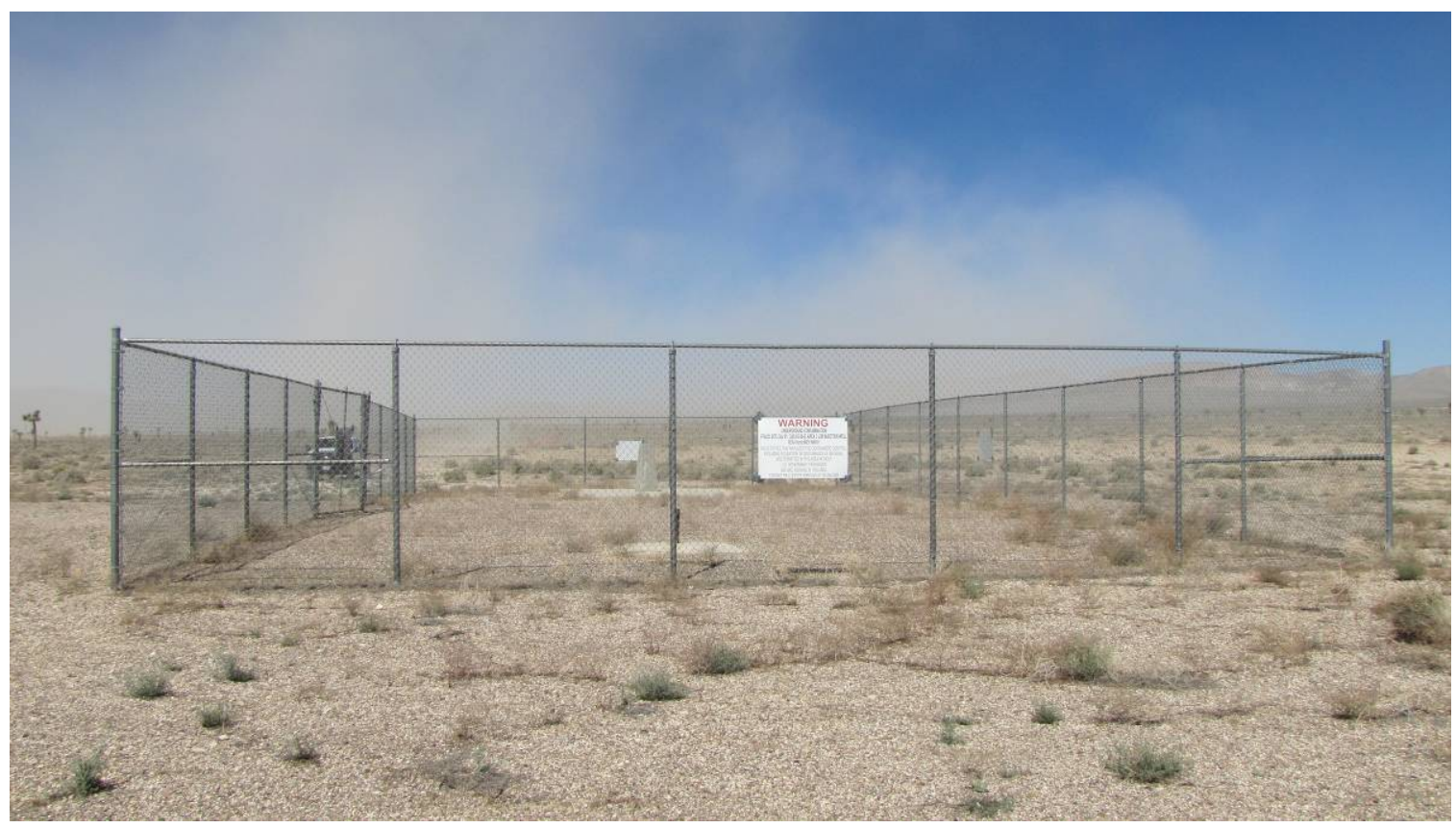

Photograph 25: CAU 91, Outside Facing North, 09/17/2013

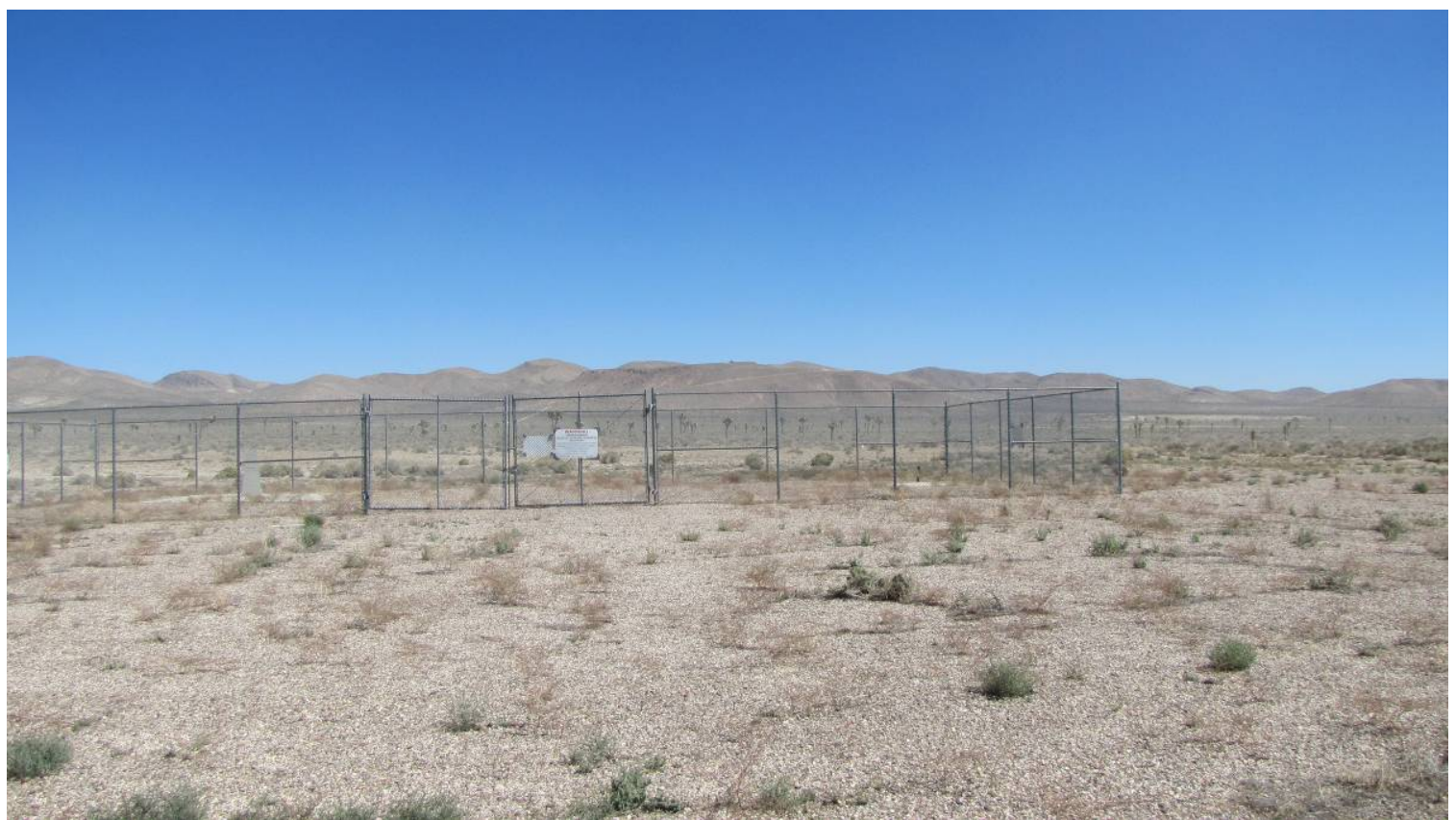

Photograph 26: CAU 91, Outside Facing East, 09/17/2013 
RCRA Post-Closure Report

Date: January 2014

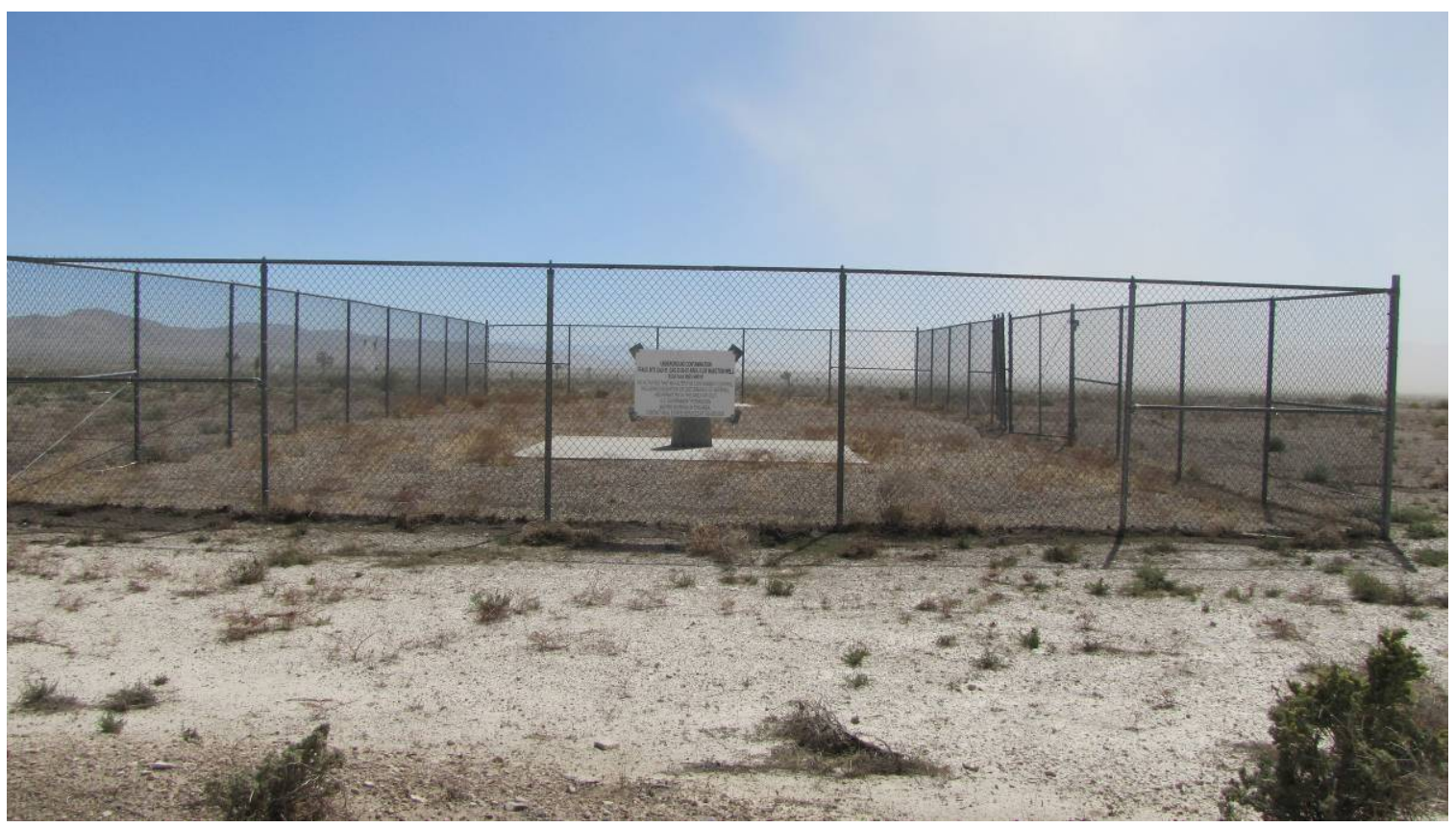

Photograph 27: CAU 91, Outside Facing South, 09/17/2013

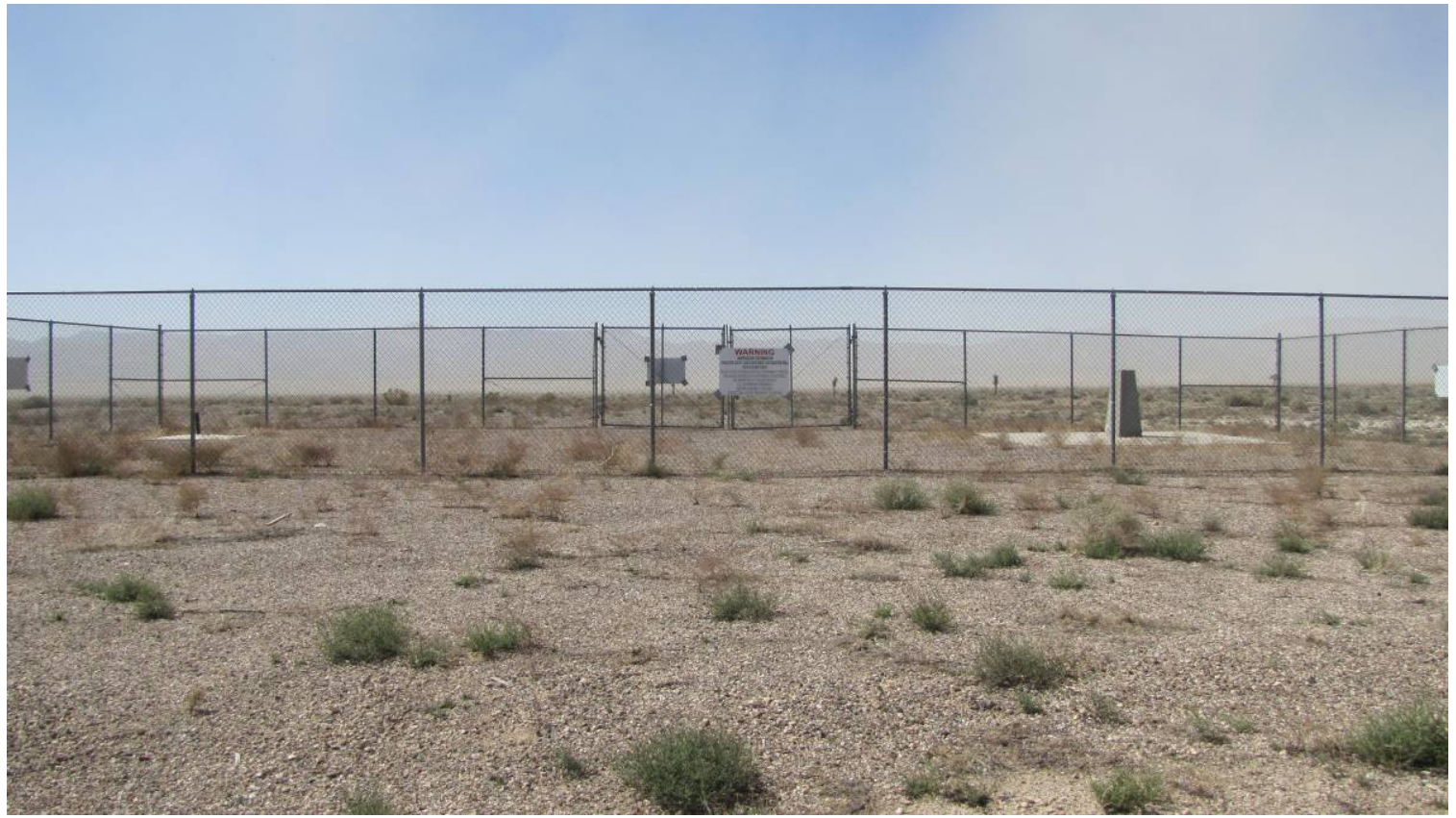

Photograph 28: CAU 91, Outside Facing West, 09/17/2013 


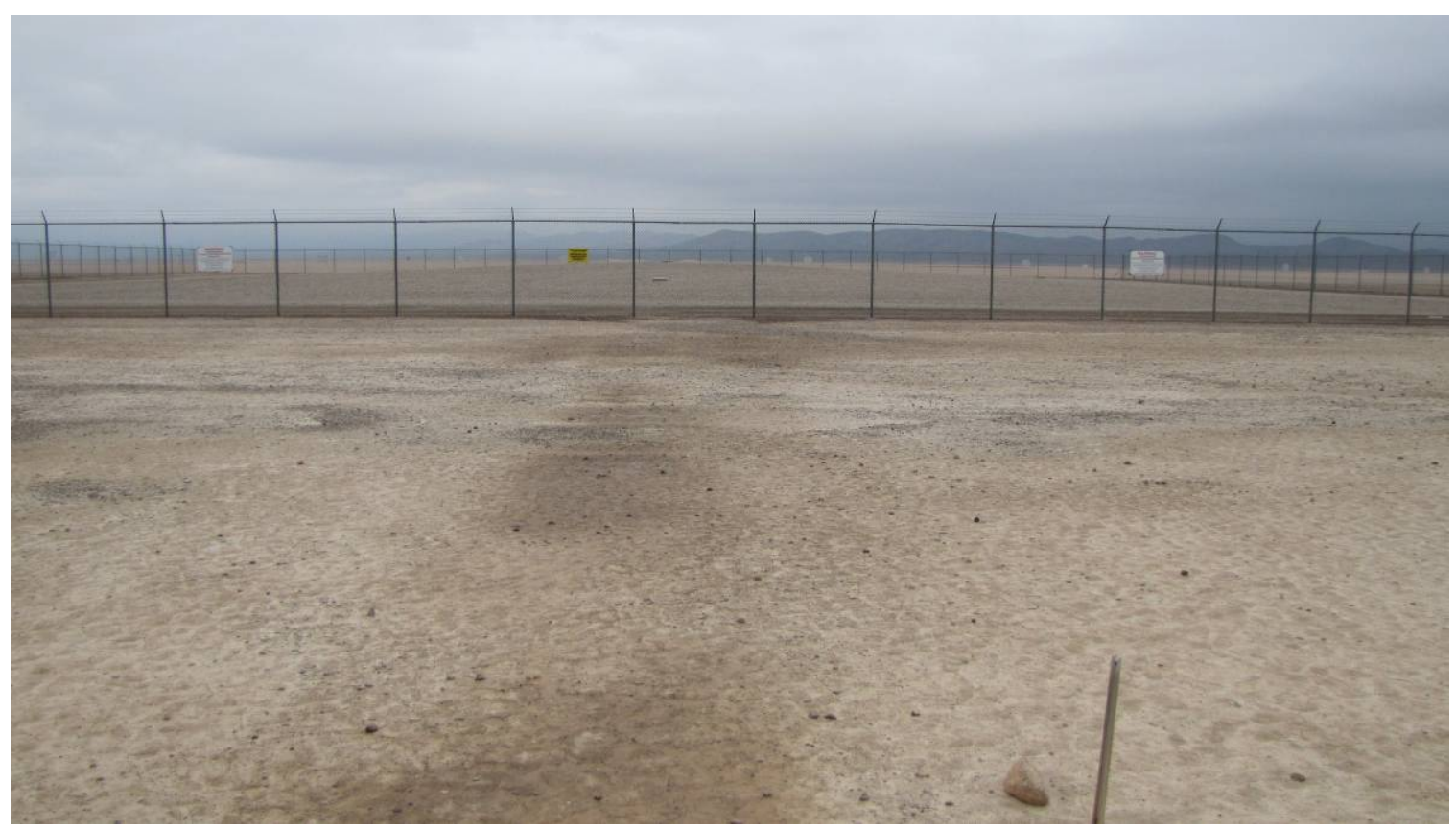

Photograph 29: CAU 92, Outside Facing North, 12/11/2012

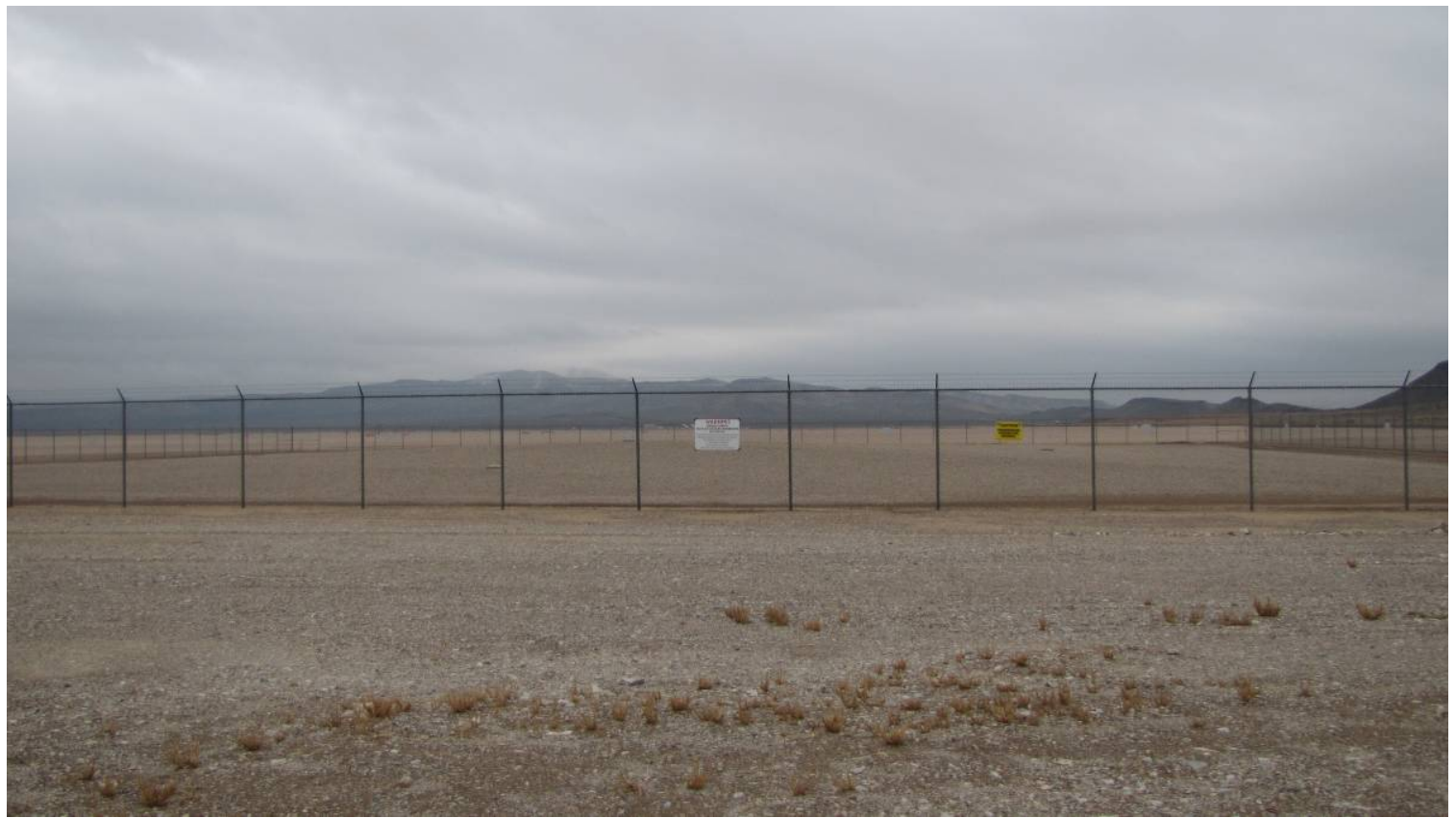

Photograph 30: CAU 92, Outside Facing East, 12/11/2012 
RCRA Post-Closure Report

Date: January 2014

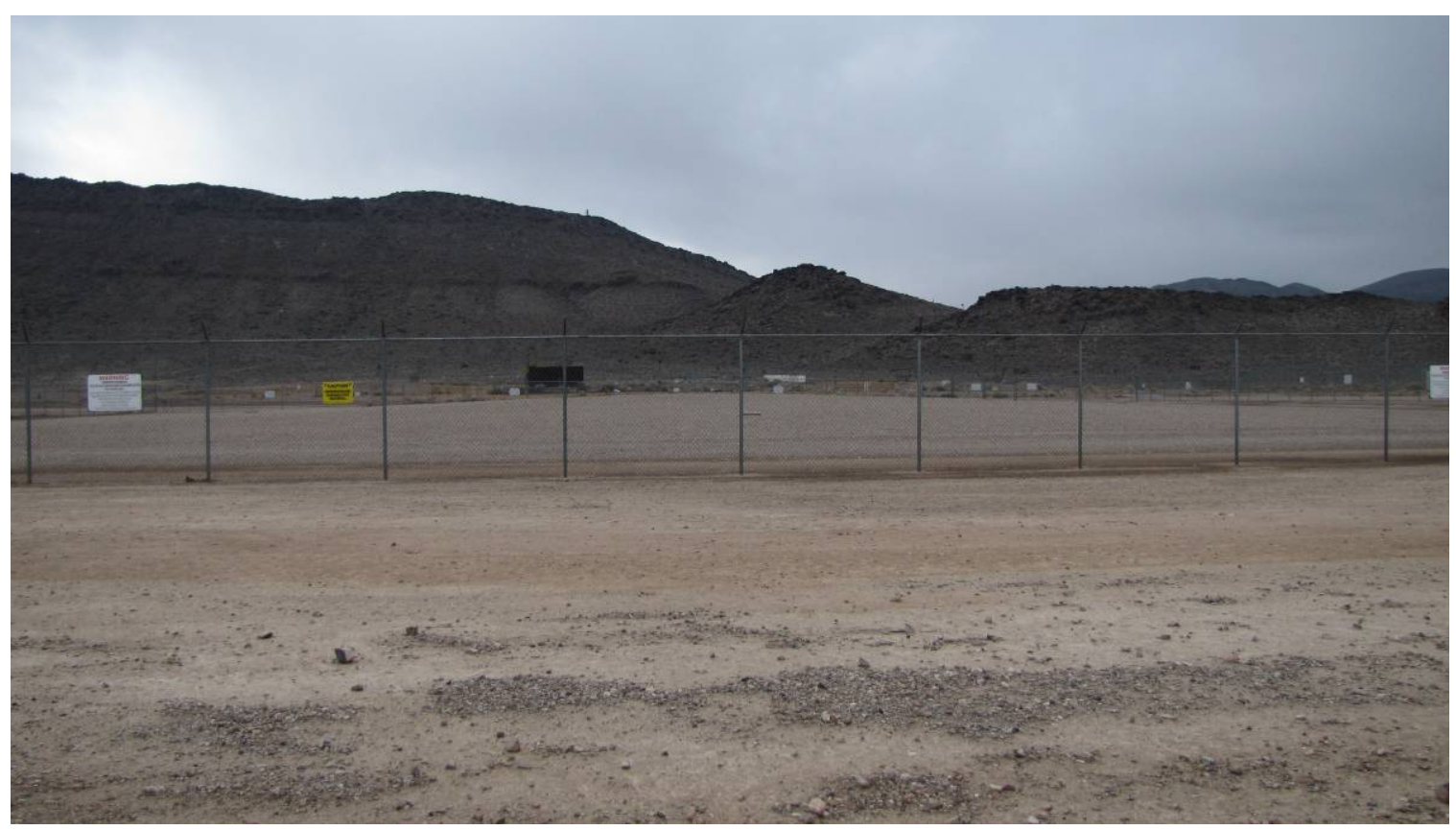

Photograph 31: CAU 92, Outside Facing South, 12/11/2012

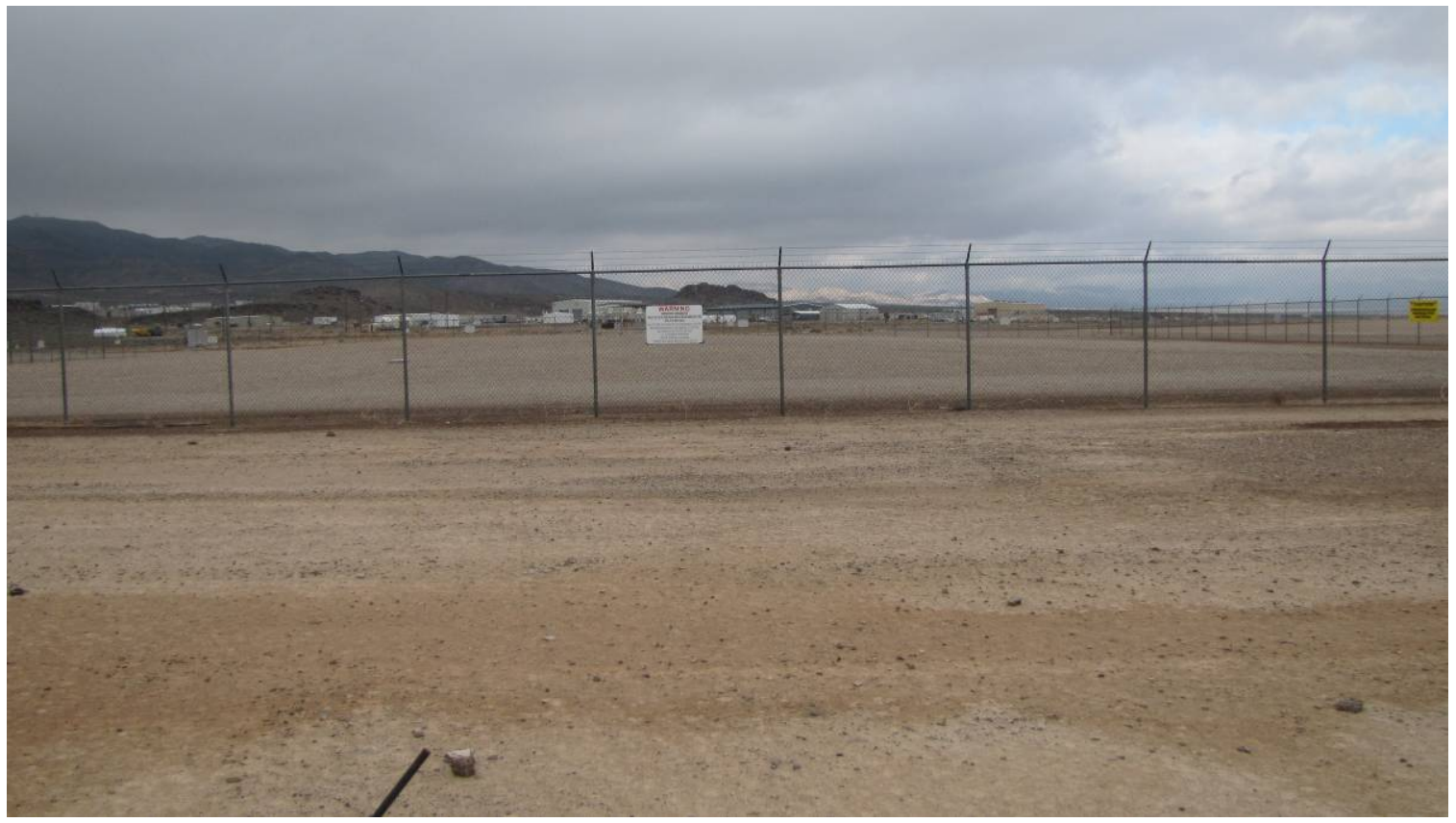

Photograph 32: CAU 92, Outside Facing West, 12/11/2012 


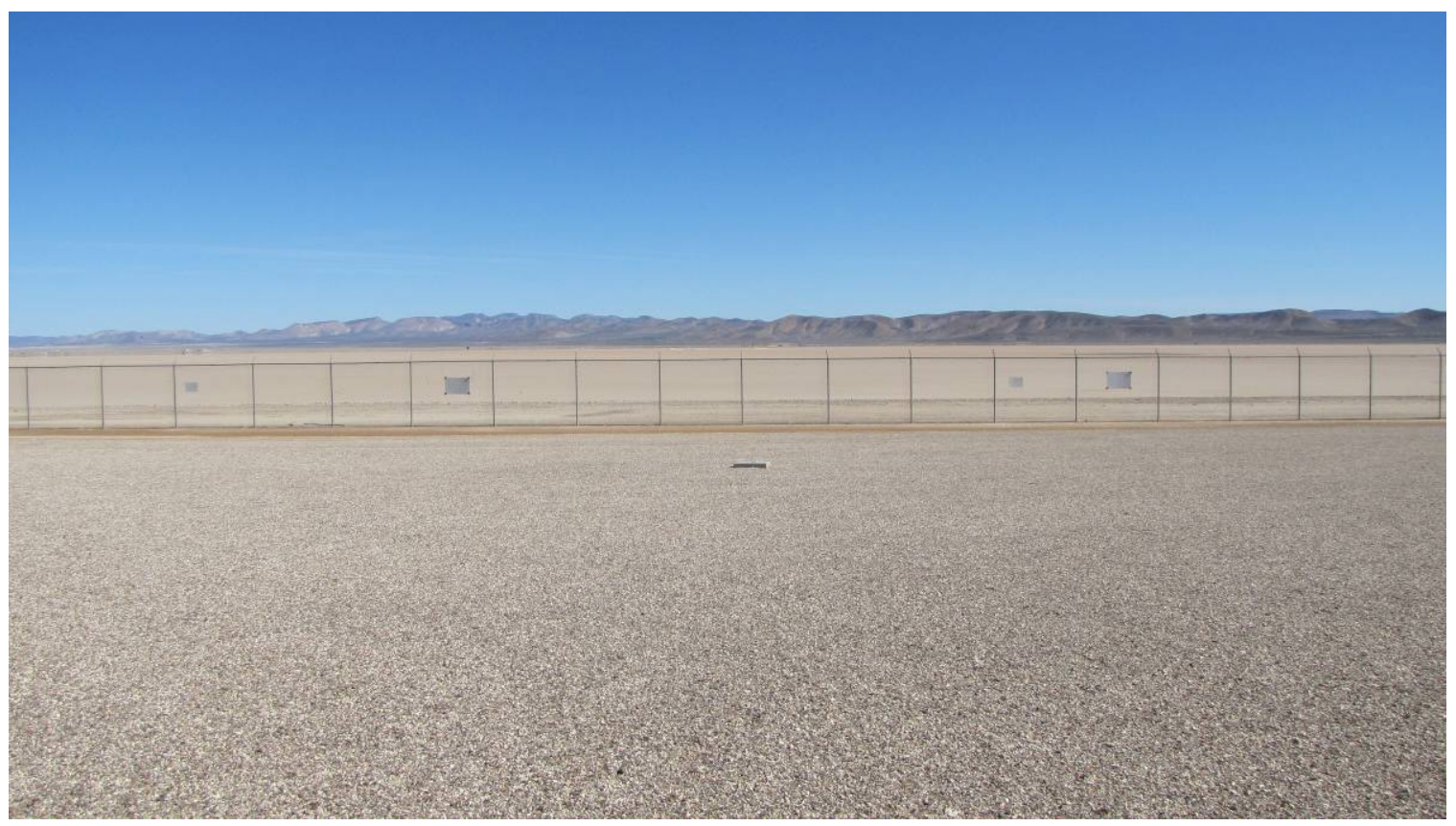

Photograph 33: CAU 92, Inside Facing North, 03/12/2013

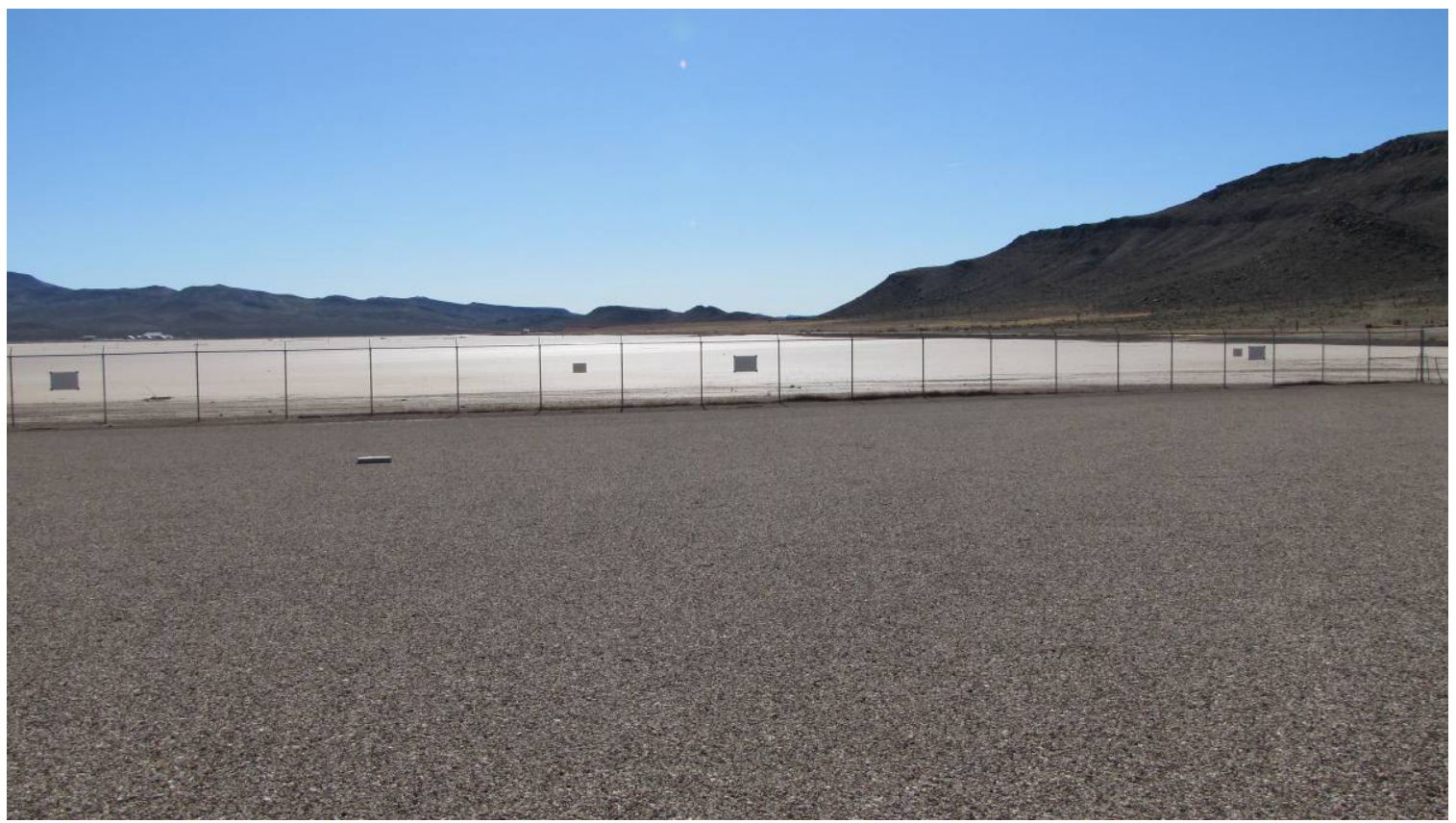

Photograph 34: CAU 92, Inside Facing East, 03/12/2013 


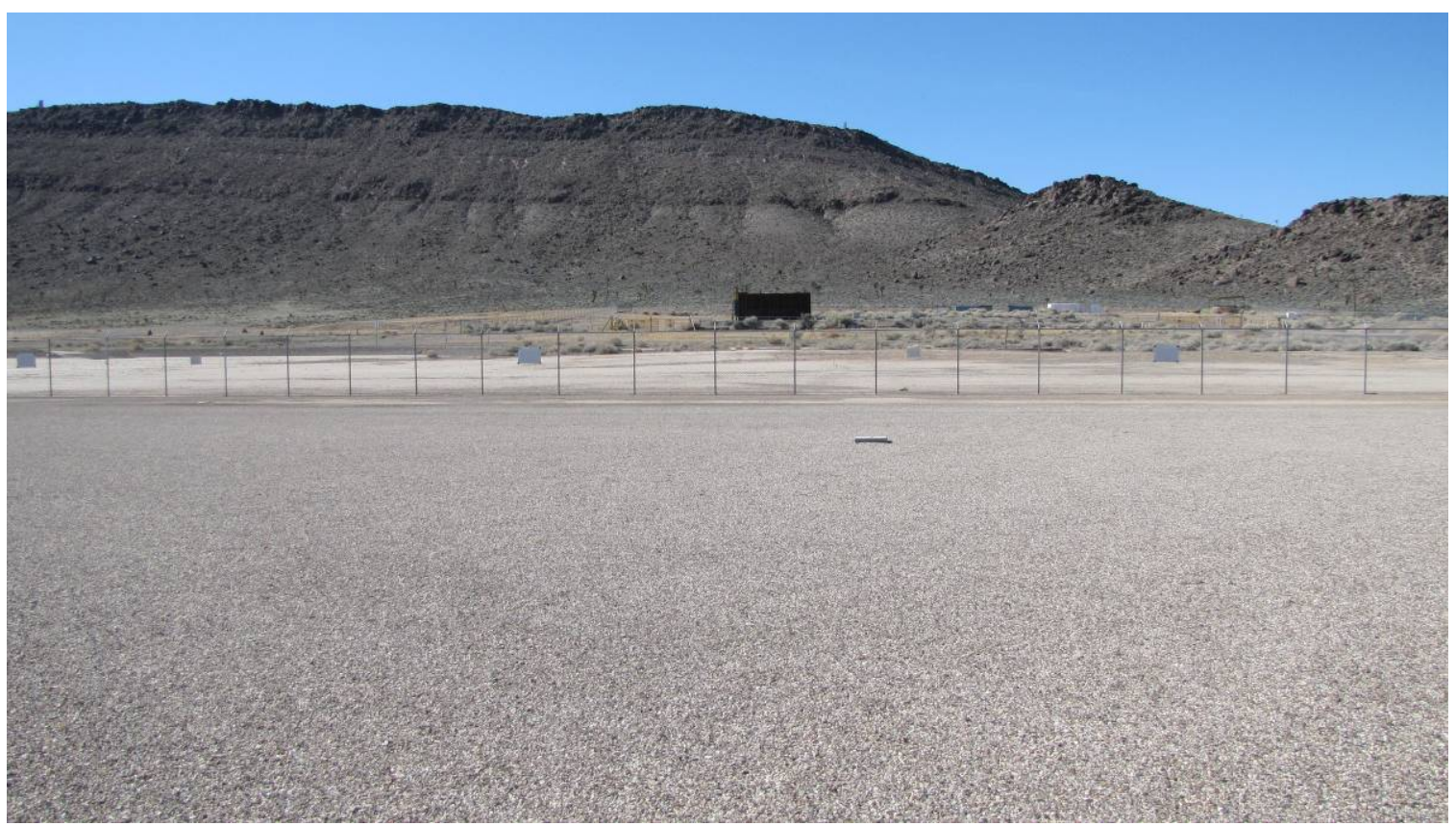

Photograph 35: CAU 92, Inside Facing South, 03/12/2013

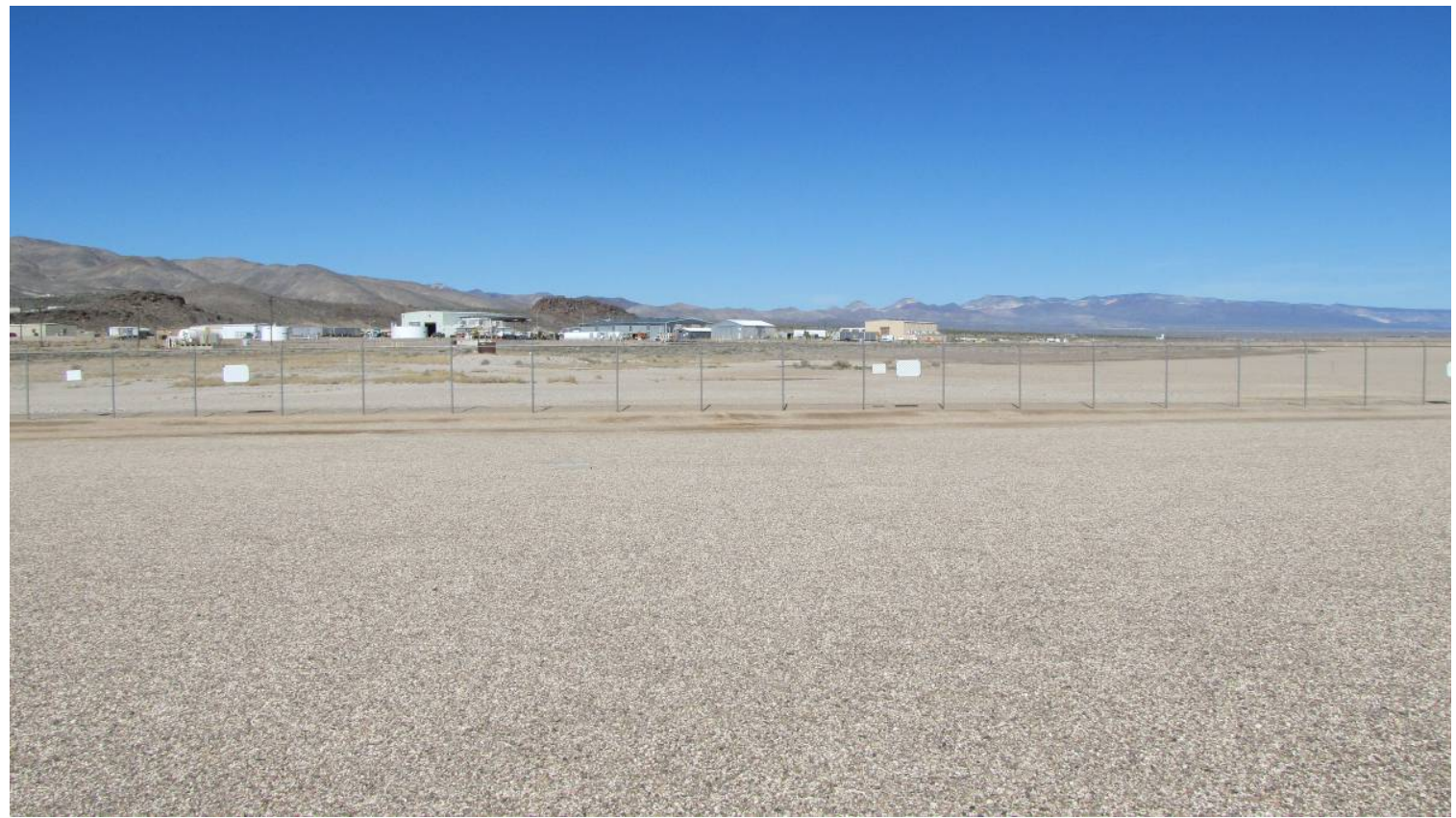

Photograph 36: CAU 92, Inside Facing West, 03/12/2013 


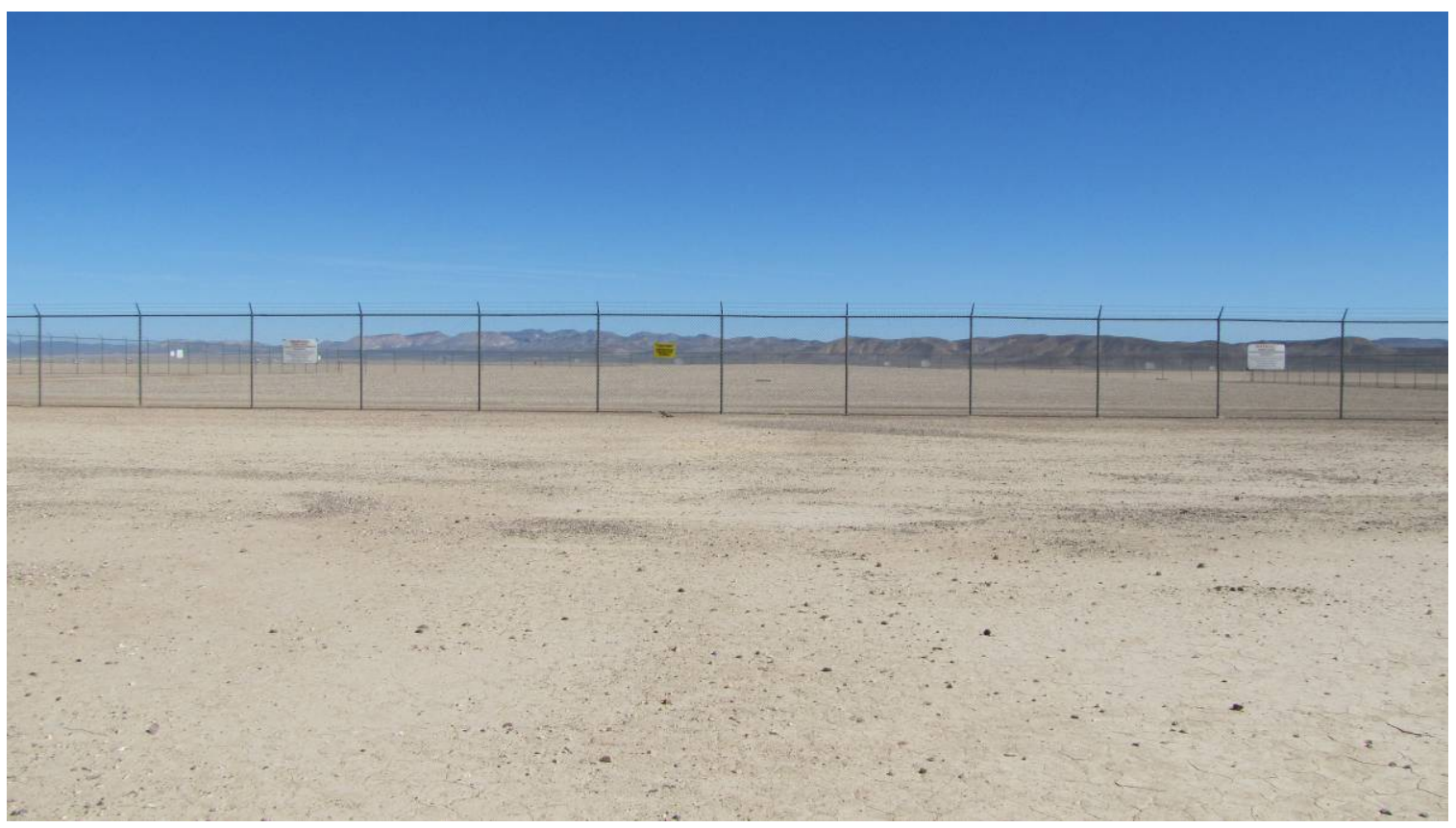

Photograph 37: CAU 92, Outside Facing North, 03/12/2013

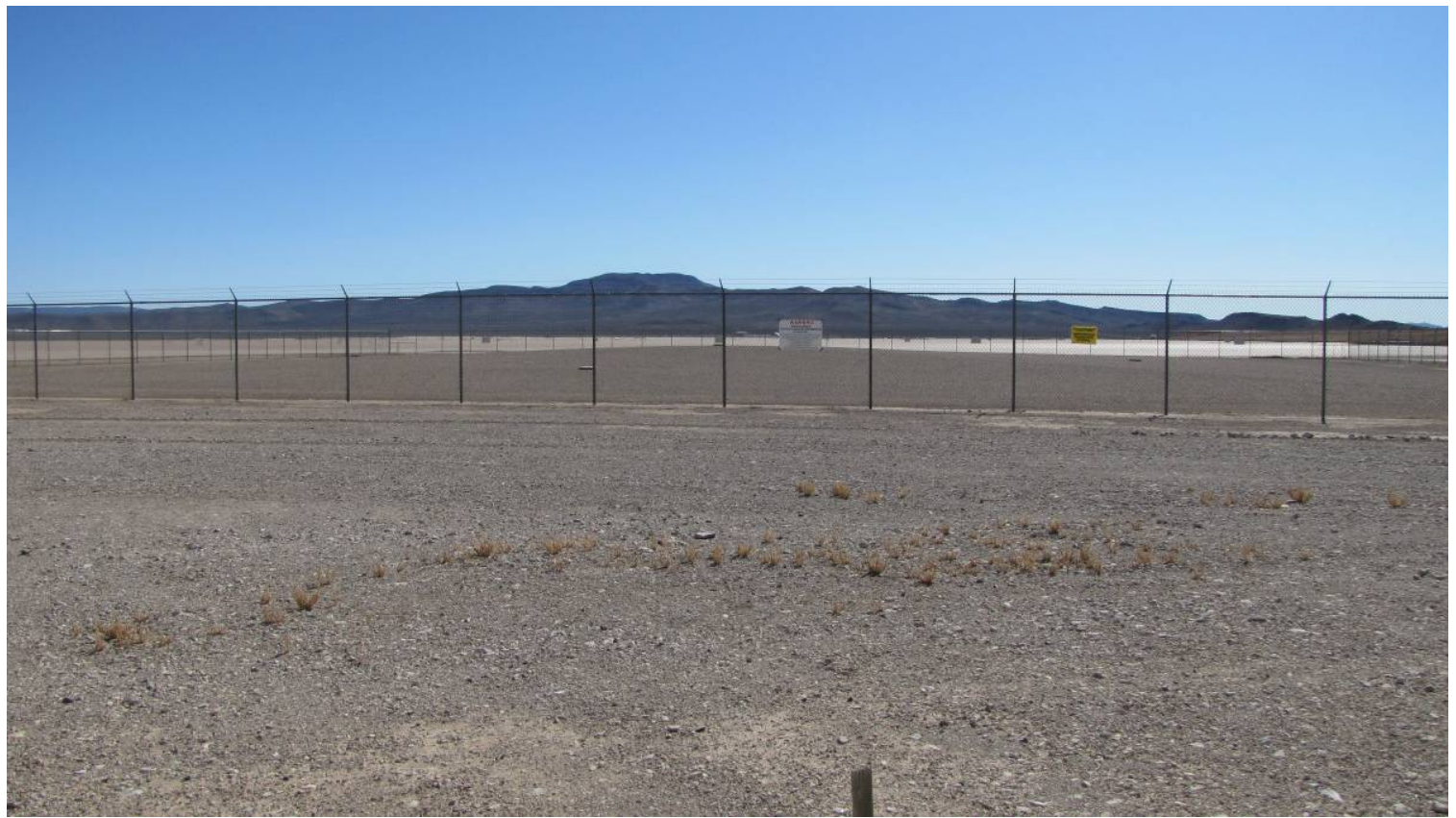

Photograph 38: CAU 92, Outside Facing East, 03/12/2013 


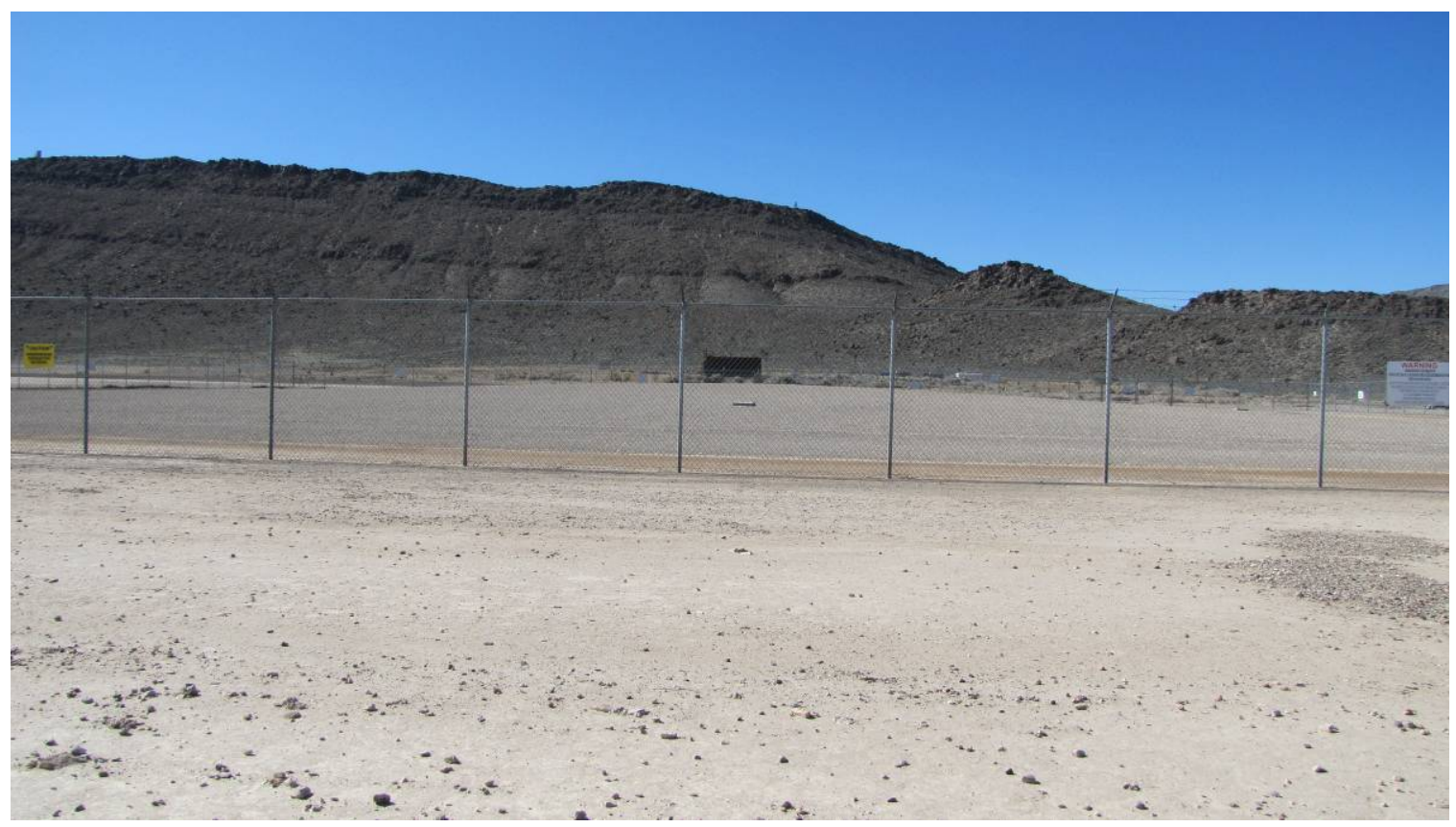

Photograph 39: CAU 92, Outside Facing South, 03/12/2013

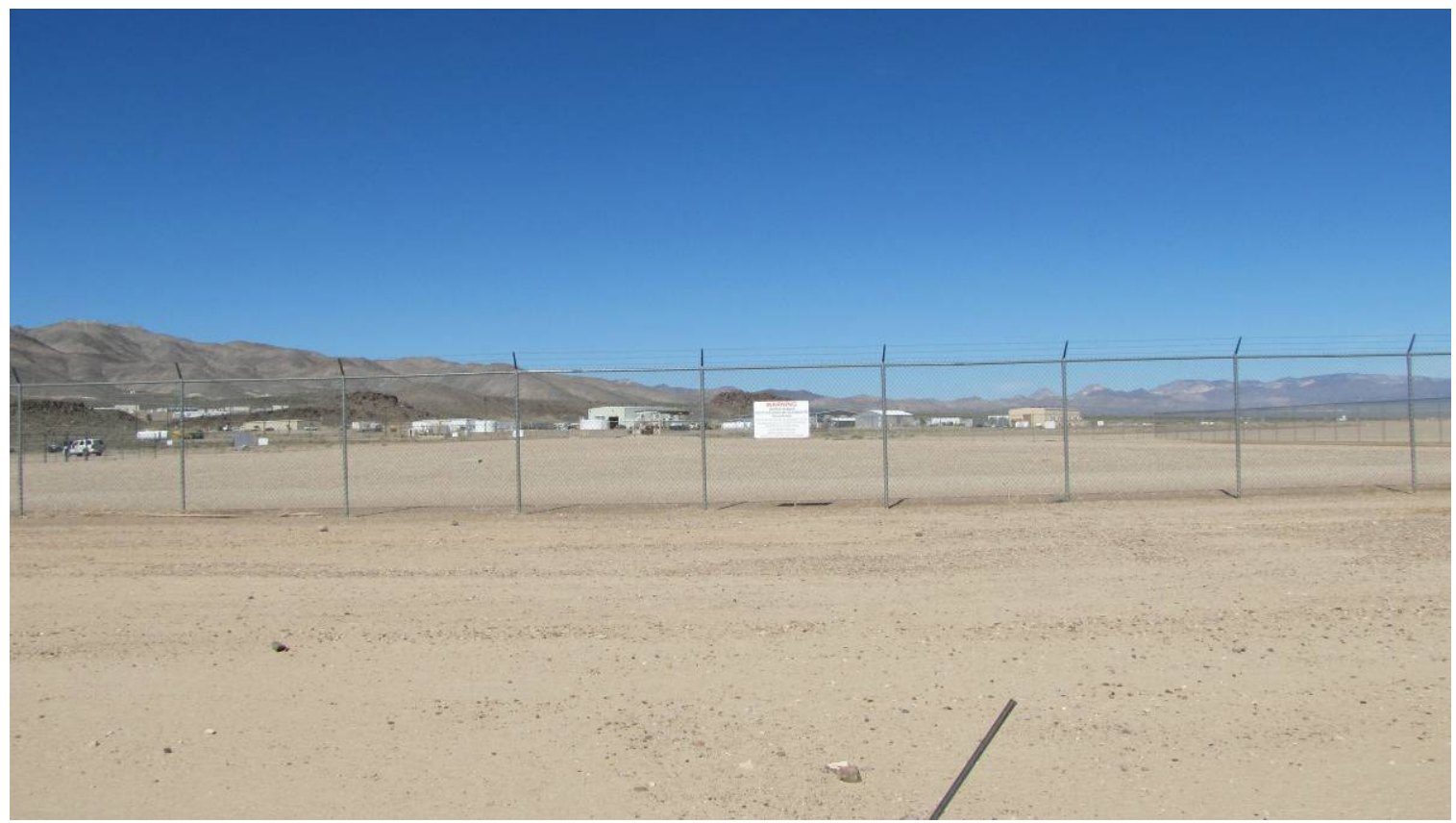

Photograph 40: CAU 92, Outside Facing West, 03/12/2013 
RCRA Post-Closure Report

Date: January 2014

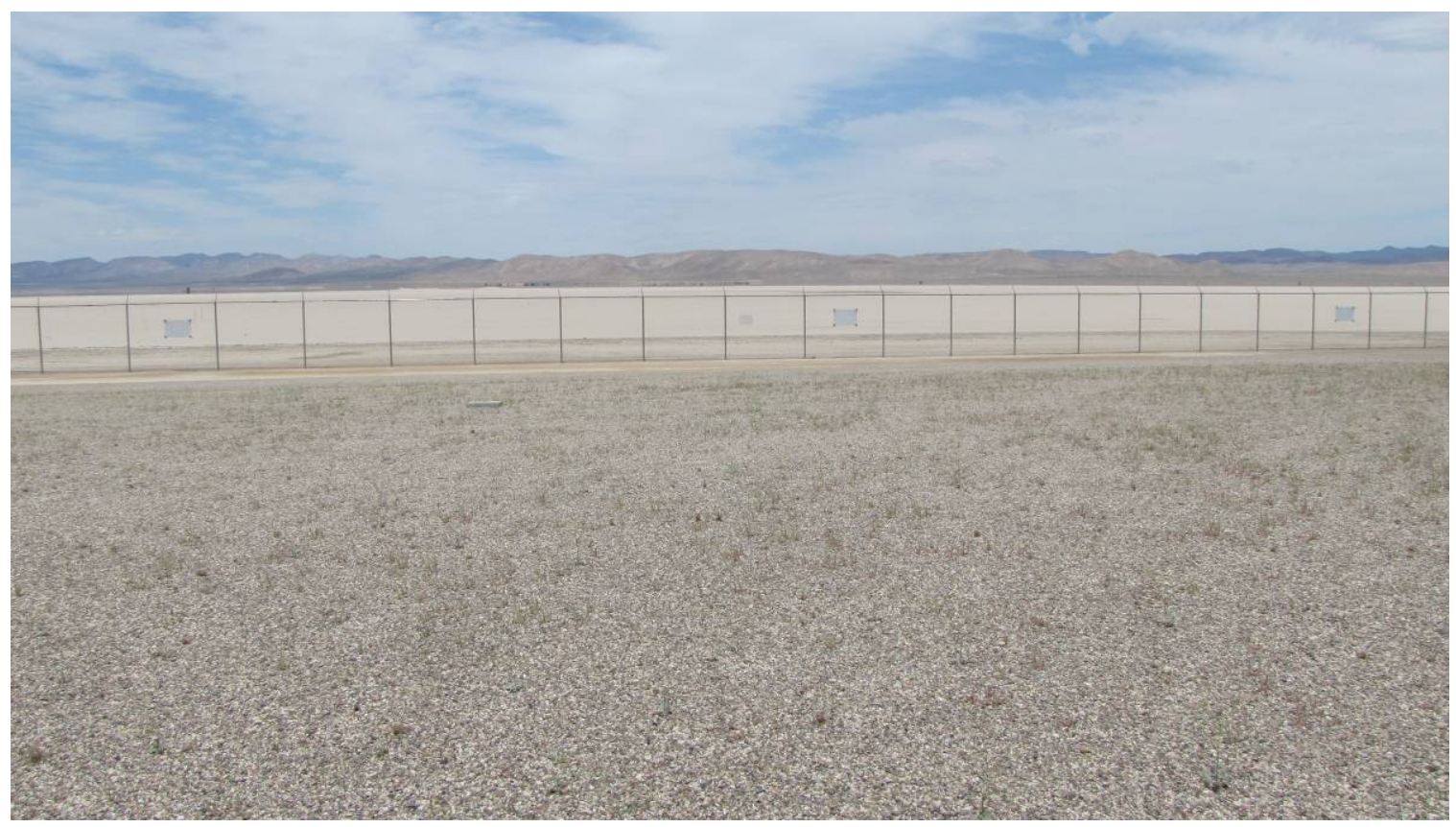

Photograph 41: CAU 92, Inside Facing North, 06/12/2013

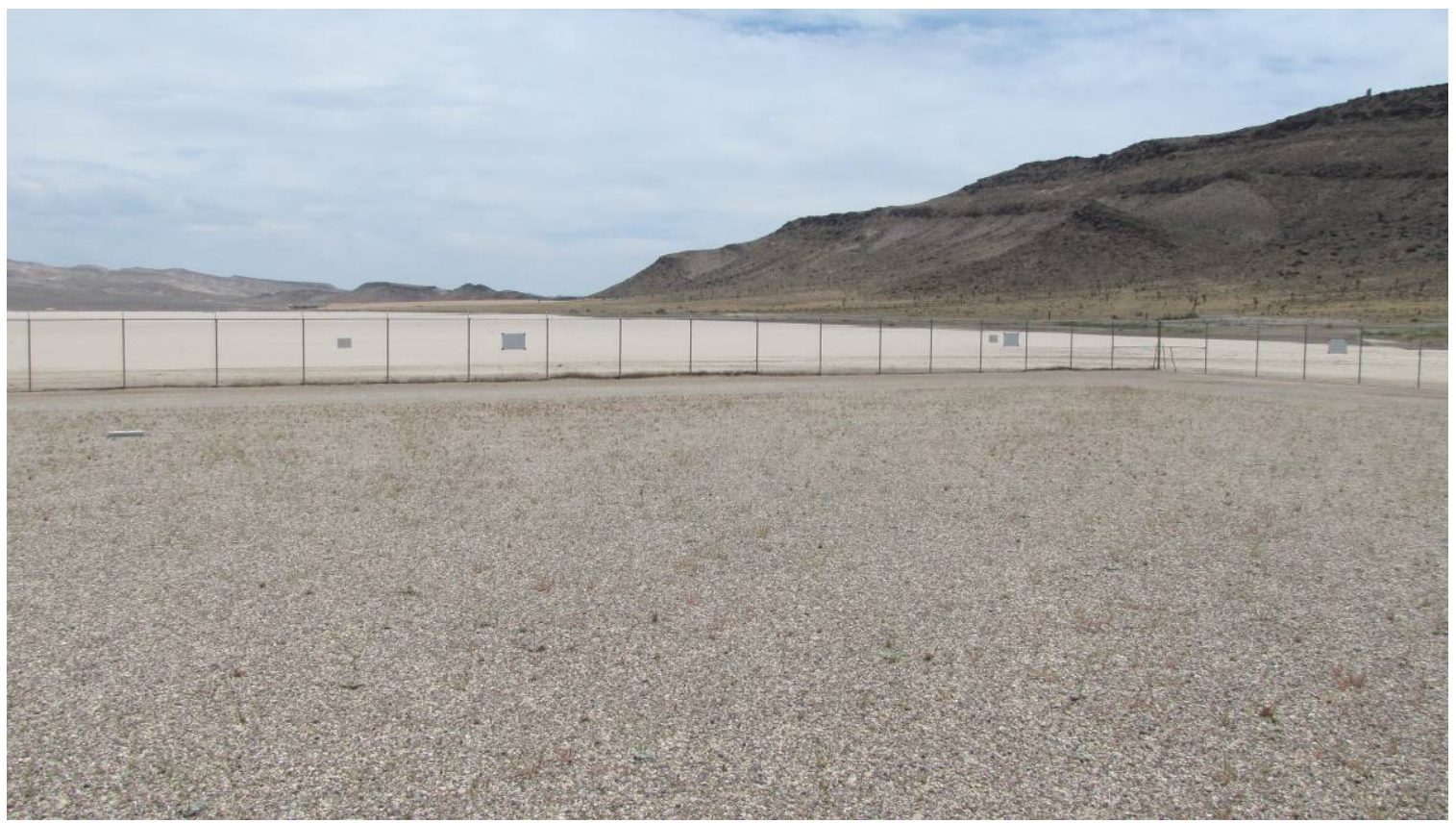

Photograph 42: CAU 92, Inside Facing East, 06/12/2013 


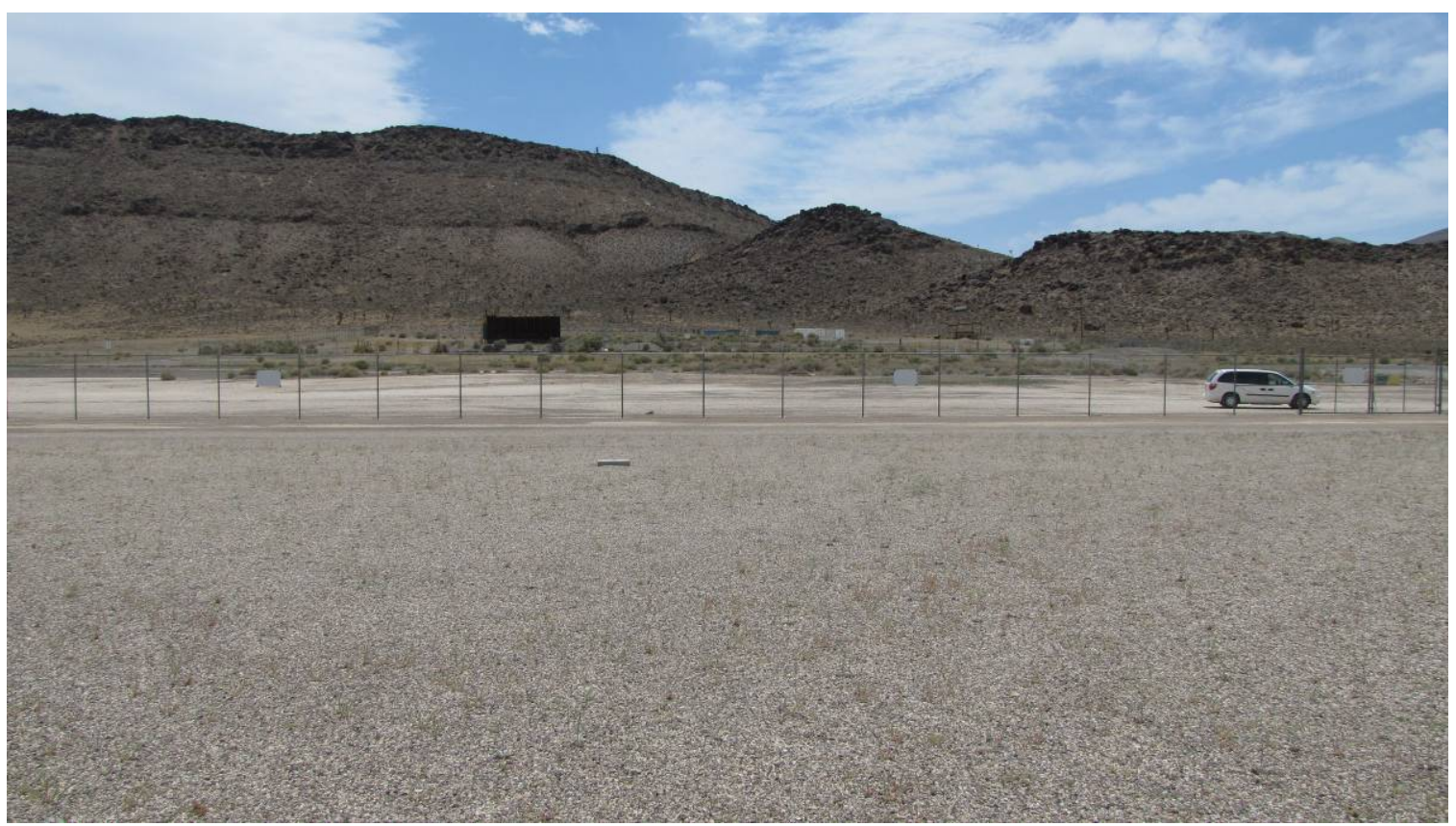

Photograph 43: CAU 92, Inside Facing South, 06/12/2013

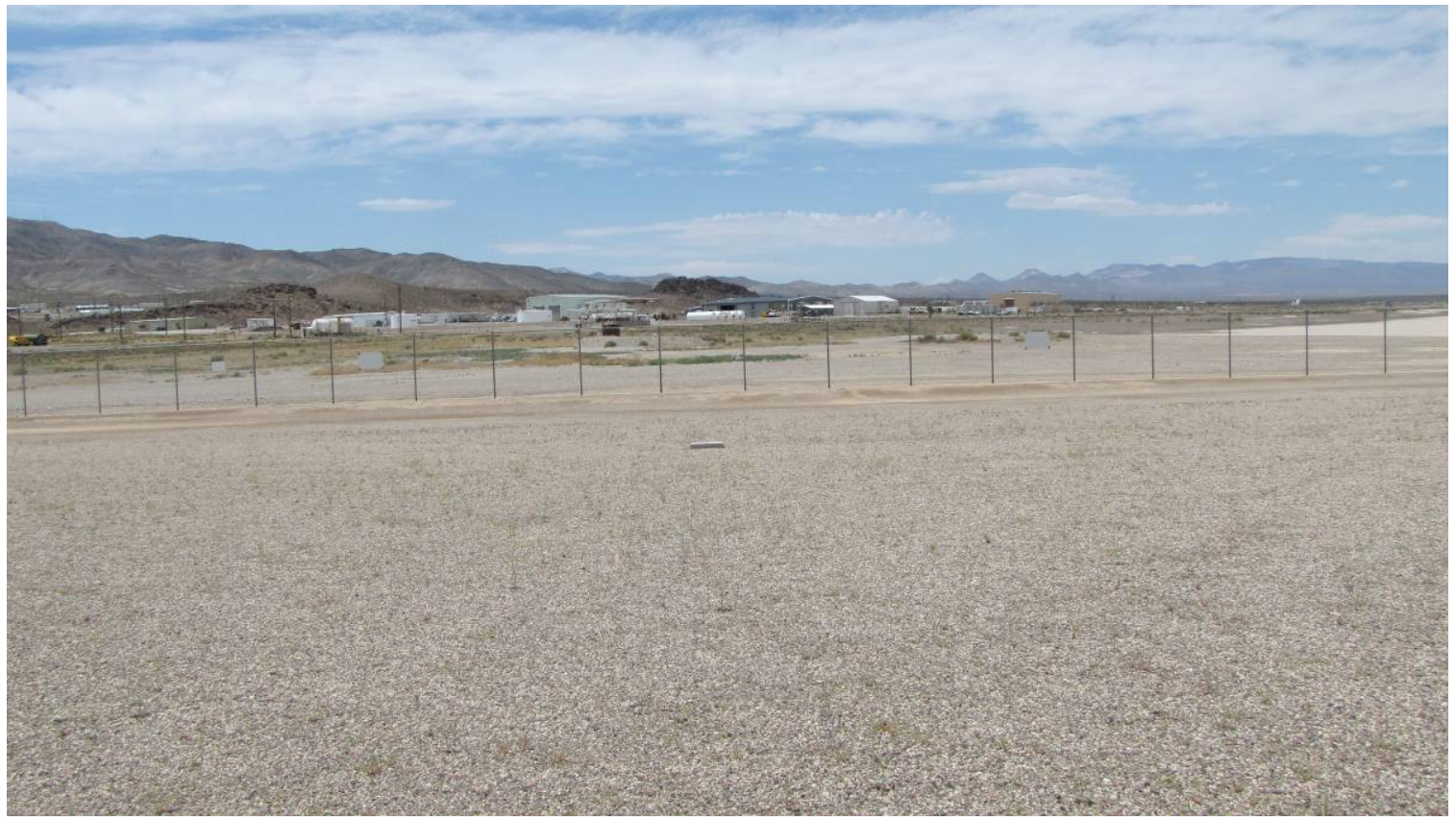

Photograph 44: CAU 92, Inside Facing West, 06/12/2013 


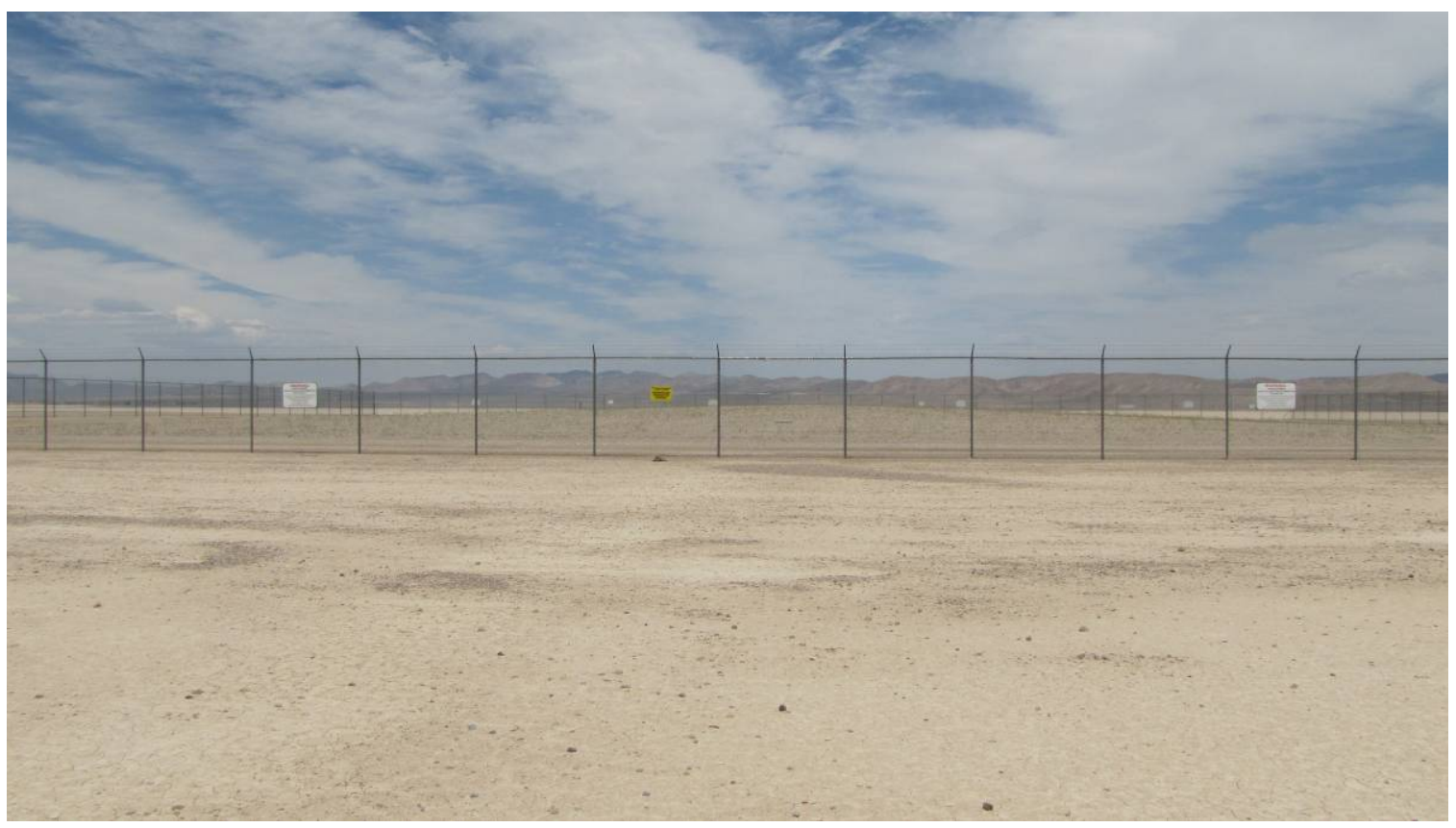

Photograph 45: CAU 92, Outside Facing North, 06/12/2013

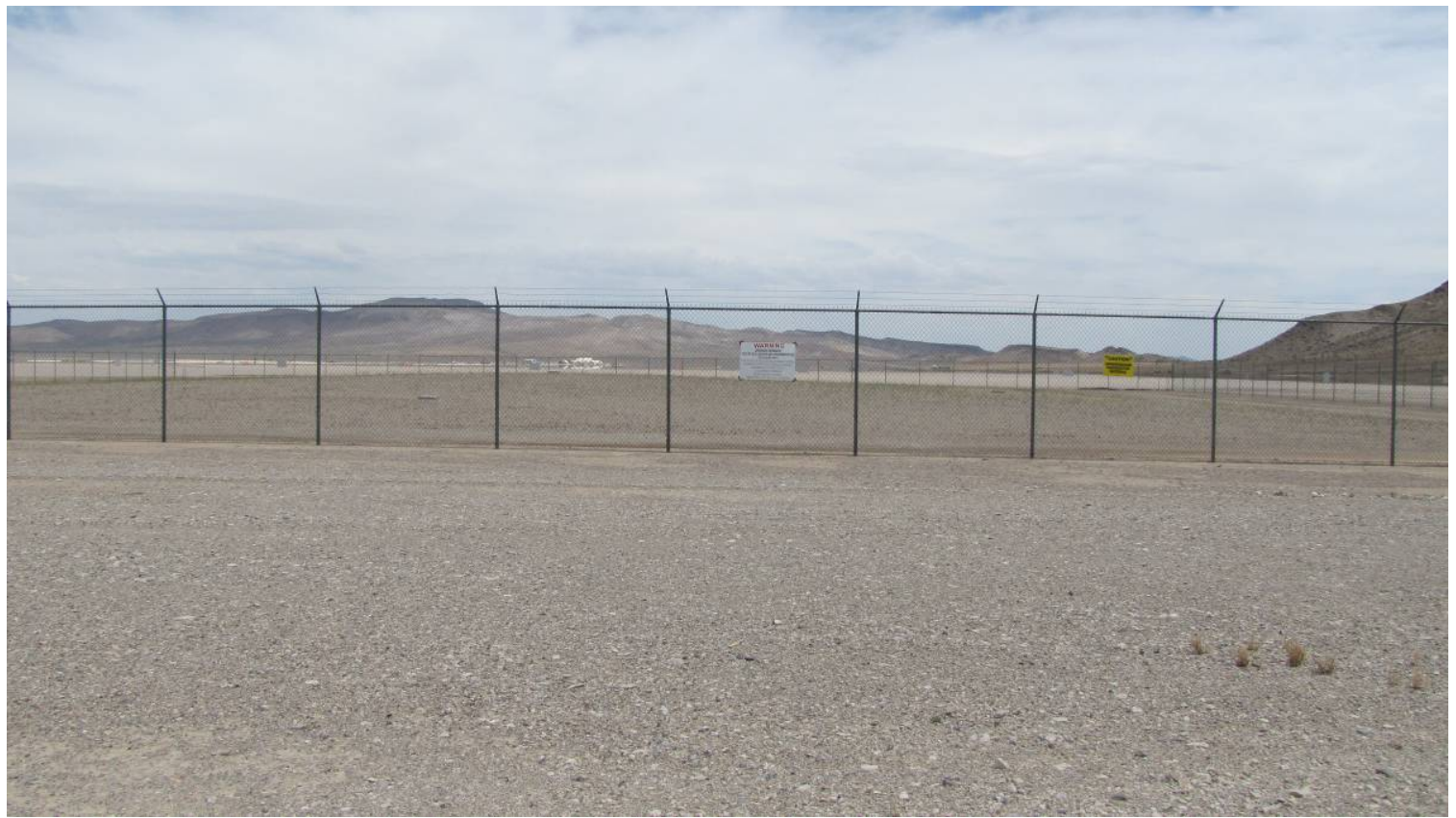

Photograph 46: CAU 92, Outside Facing East, 06/12/2013 


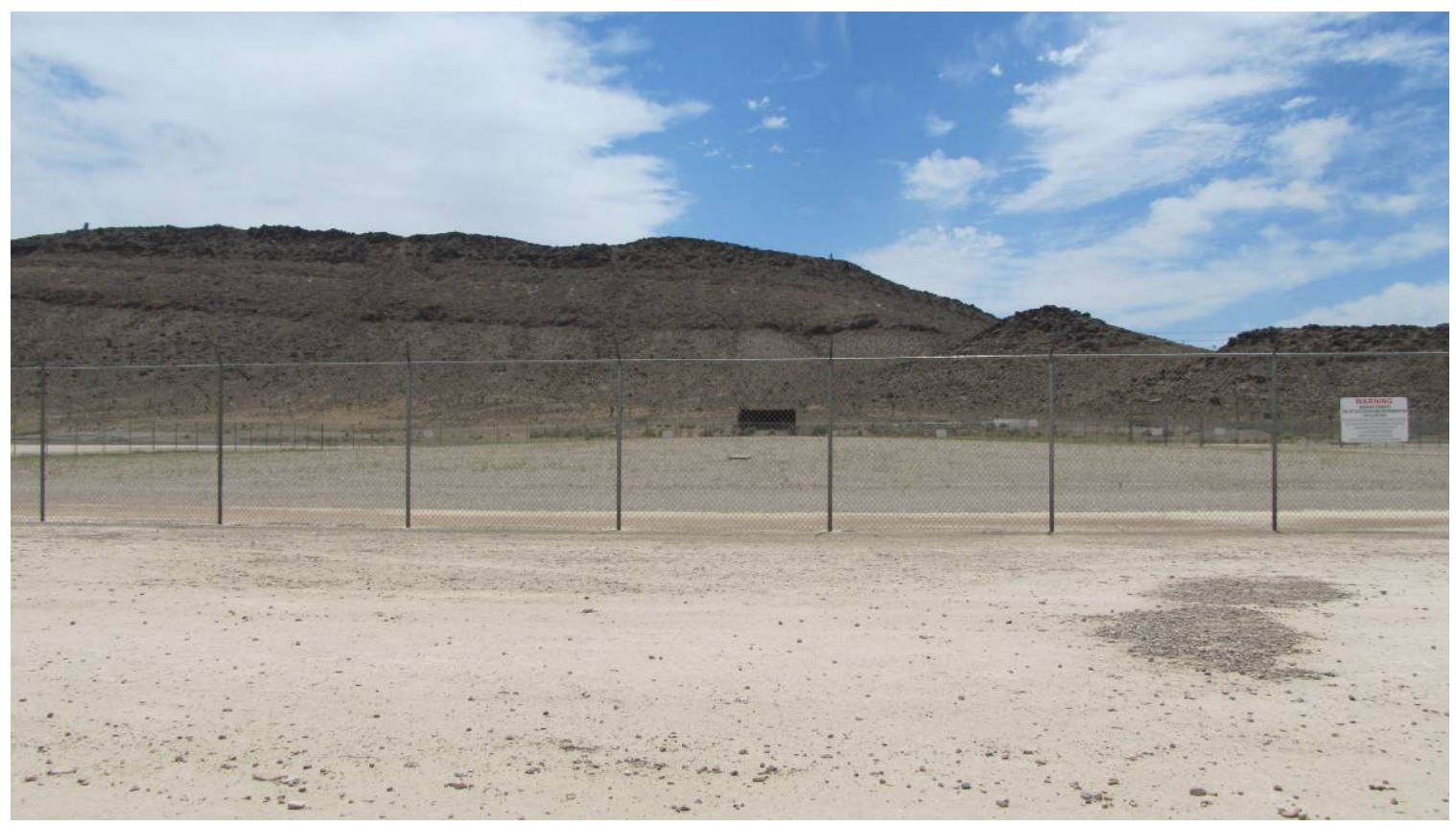

Photograph 47: CAU 92, Outside Facing South, 06/12/2013

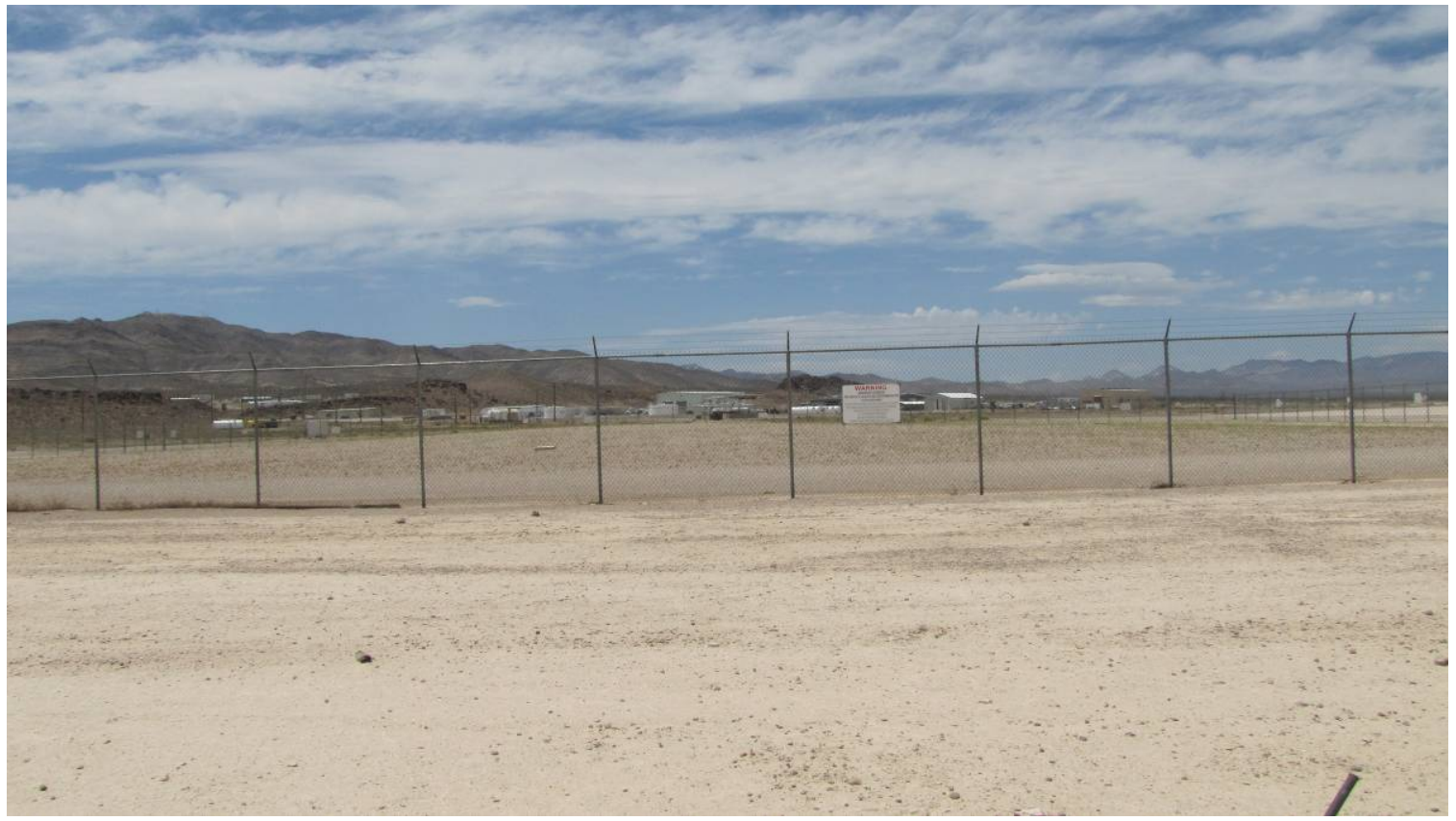

Photograph 48: CAU 92, Outside Facing West, 06/12/2013 


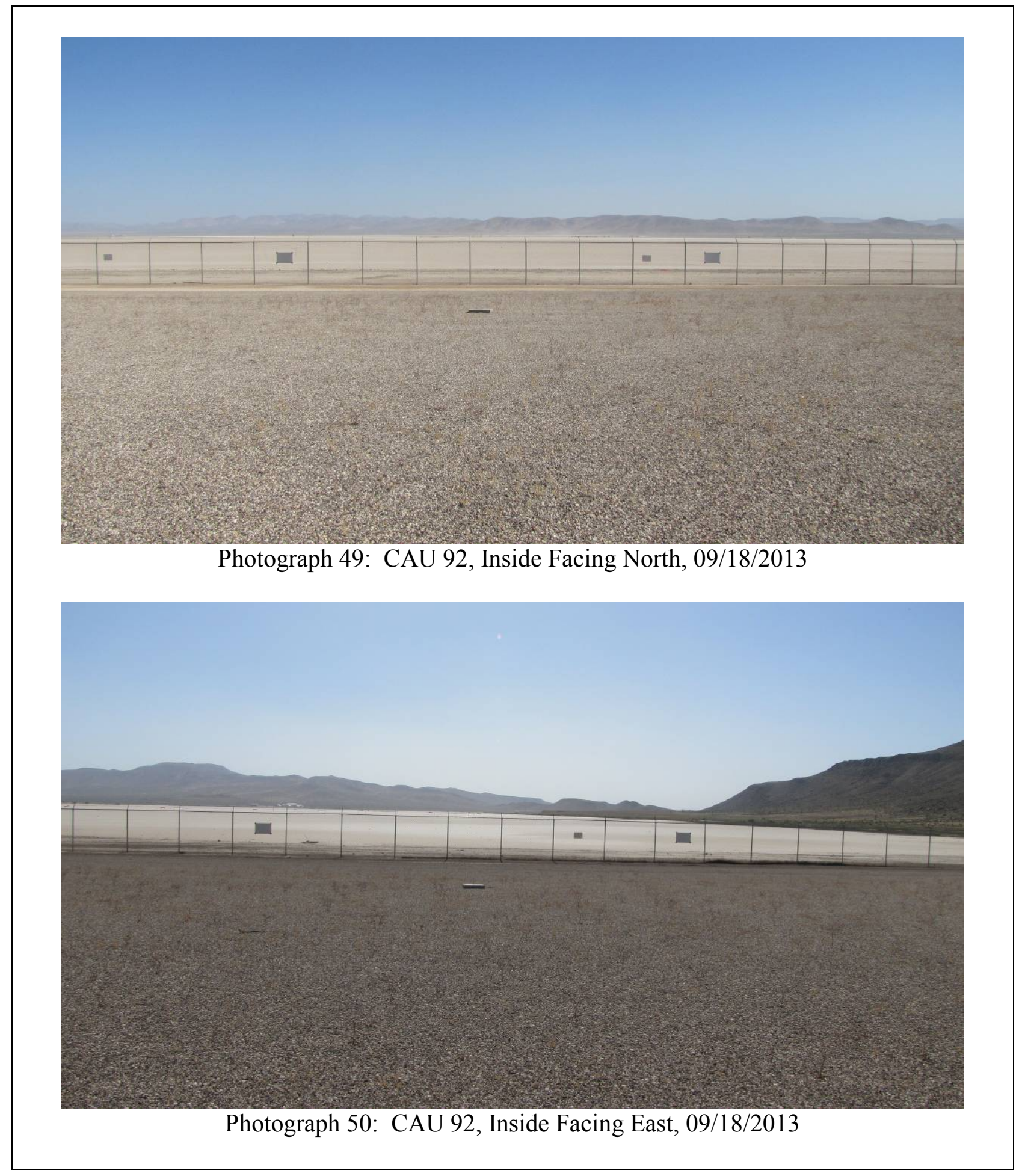




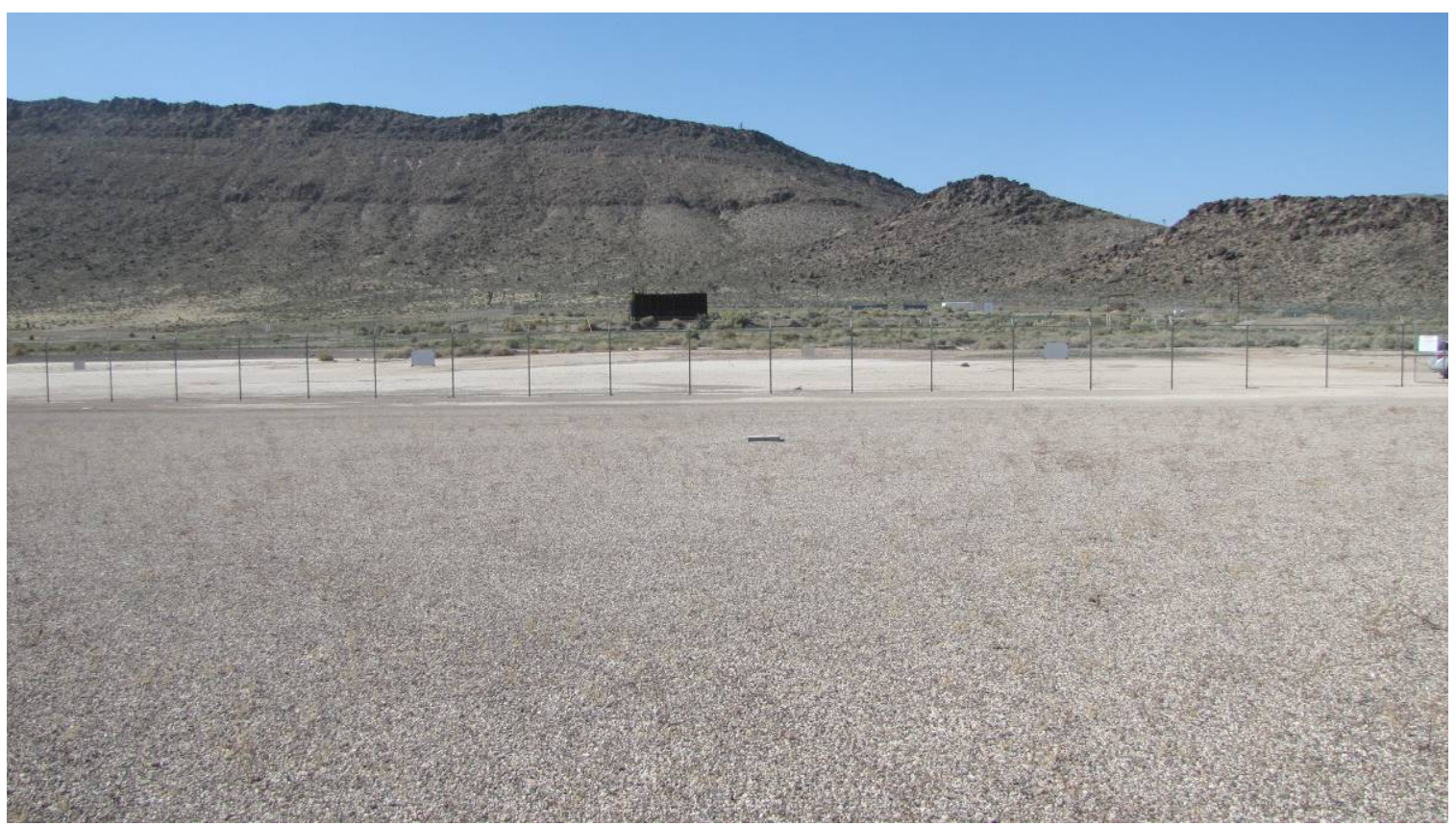

Photograph 51: CAU 92, Inside Facing South, 09/18/2013

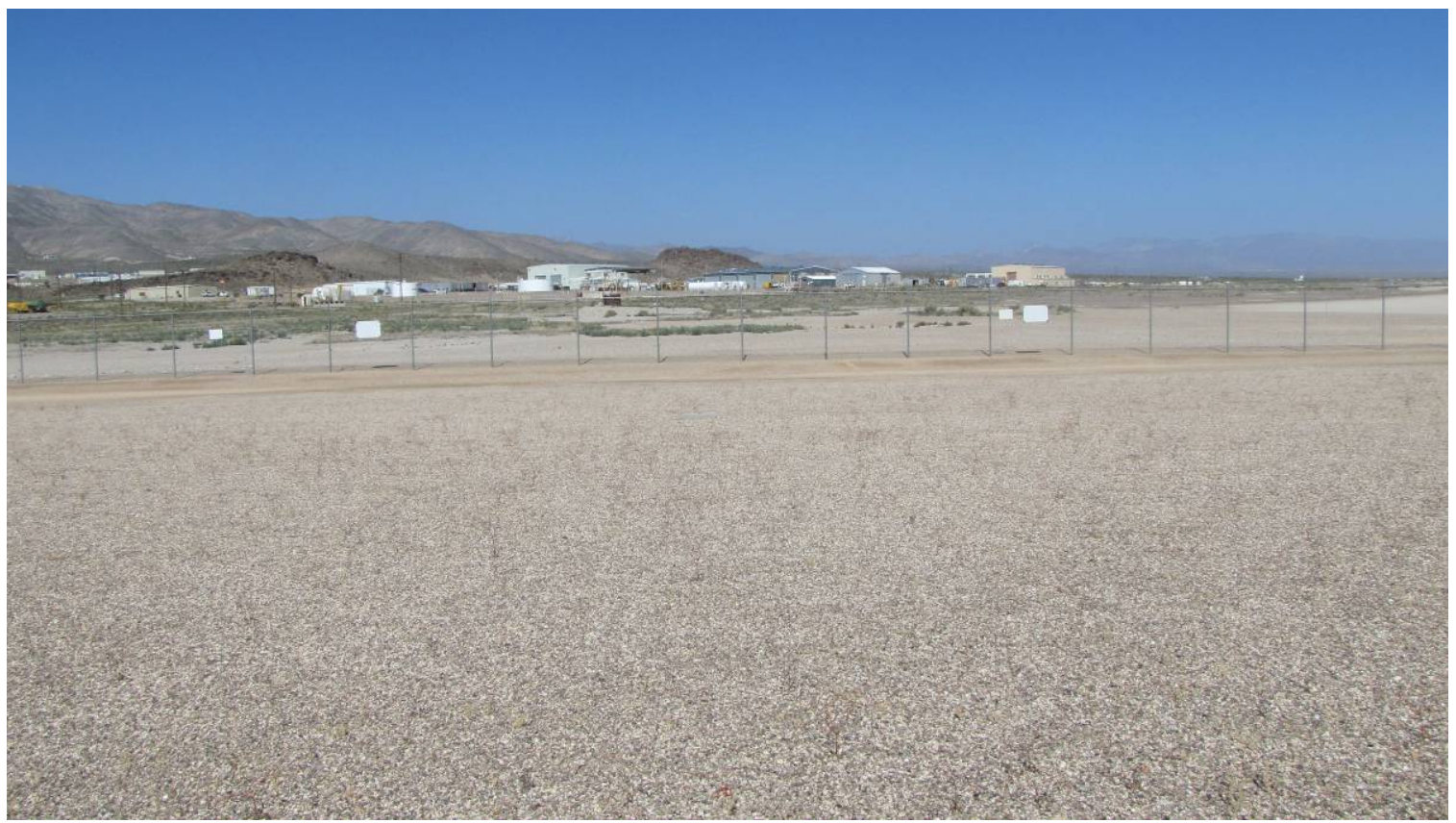

Photograph 52: CAU 92, Inside Facing West, 09/18/2013 


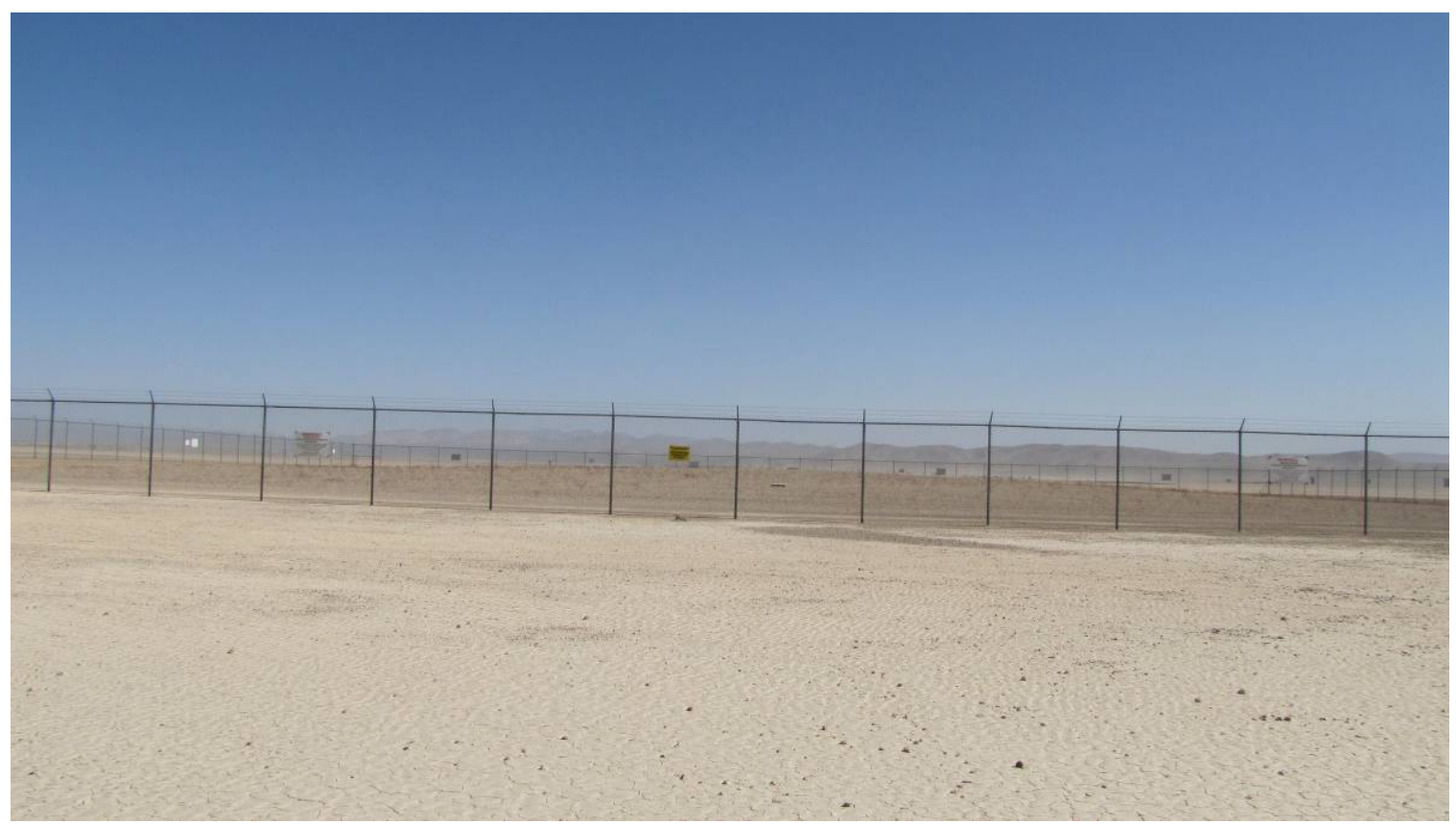

Photograph 53: CAU 92, Outside Facing North, 09/18/2013

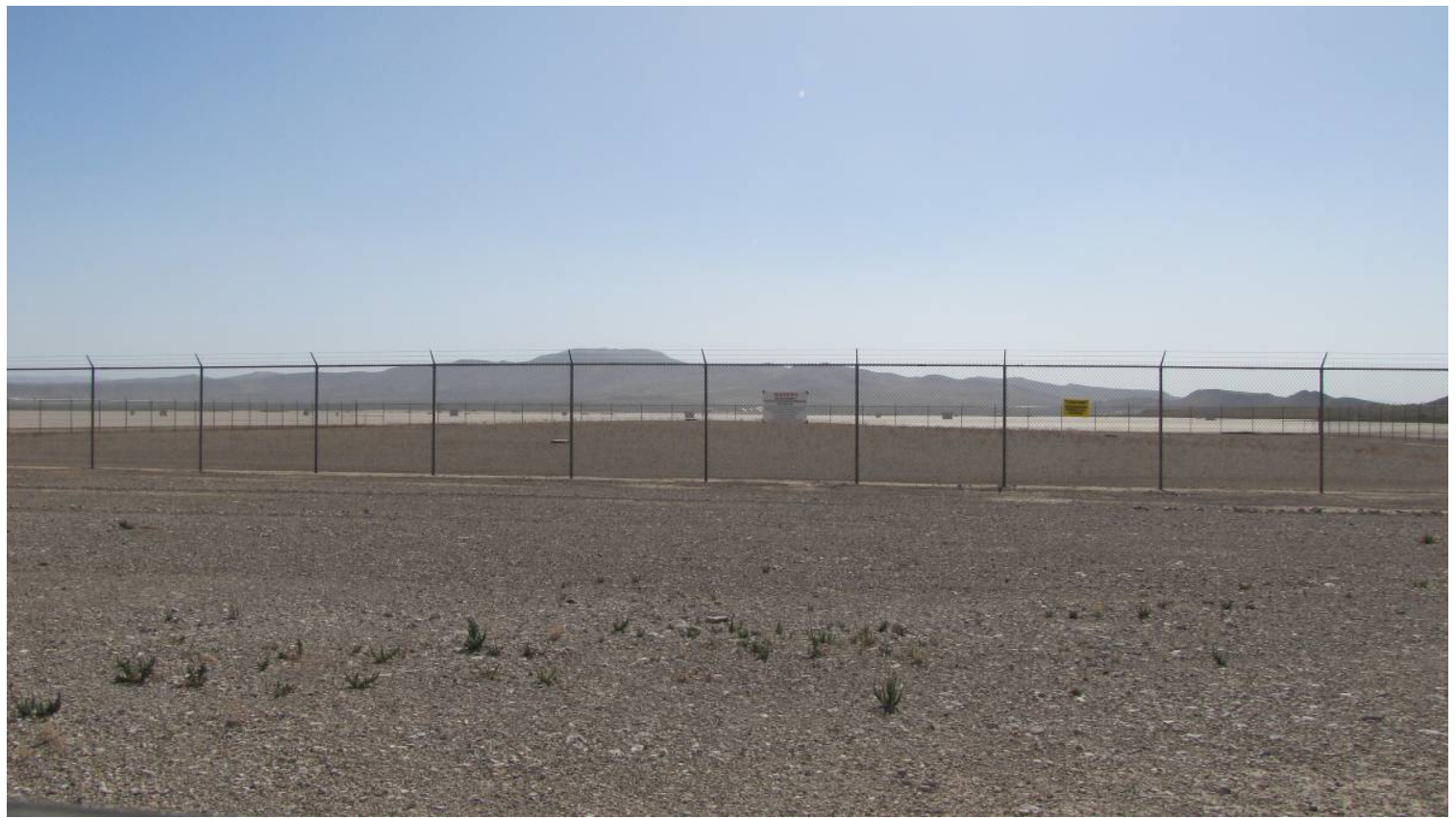

Photograph 54: CAU 92, Outside Facing East, 09/18/2013 


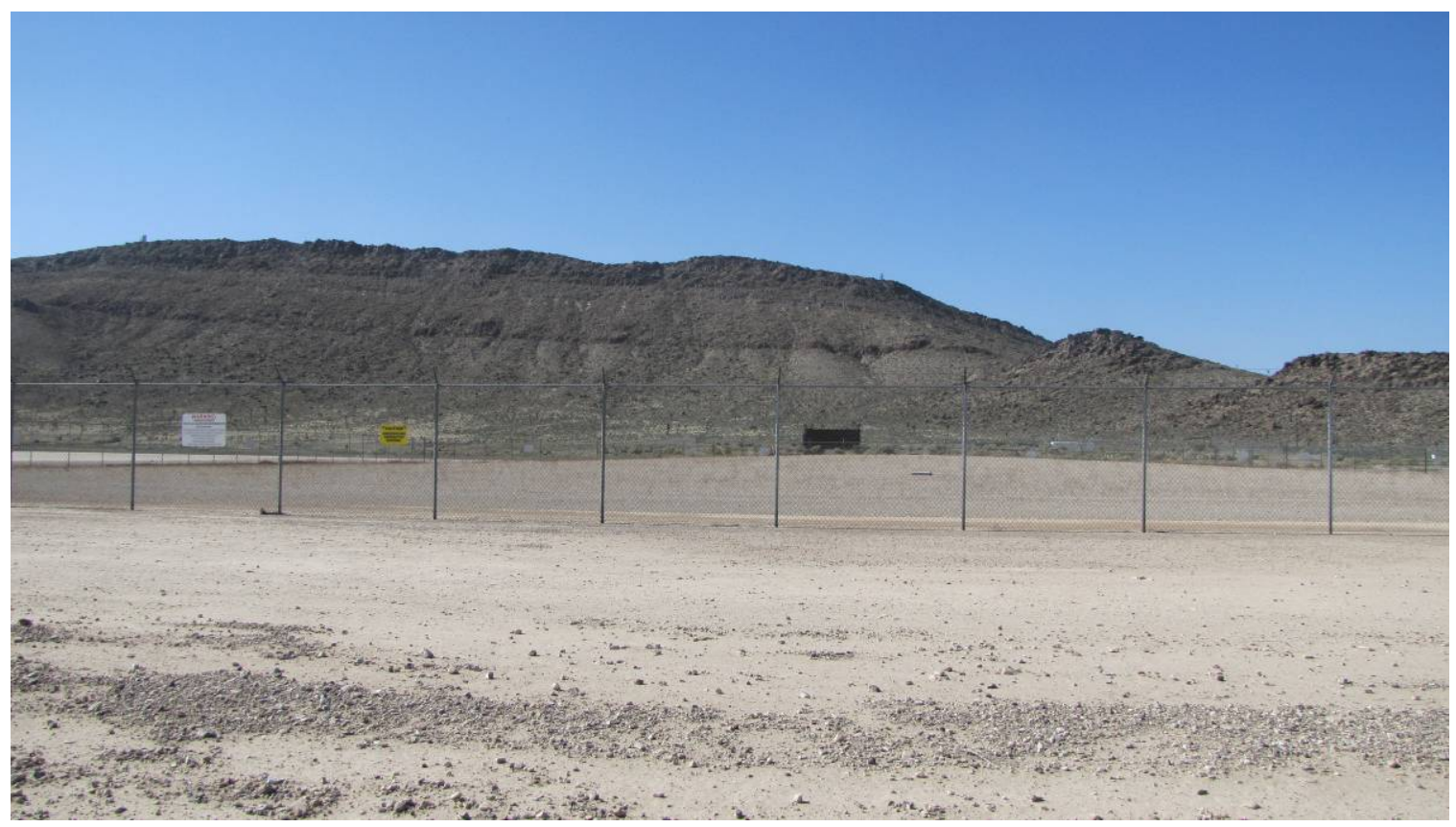

Photograph 55: CAU 92, Outside Facing South, 09/18/2013

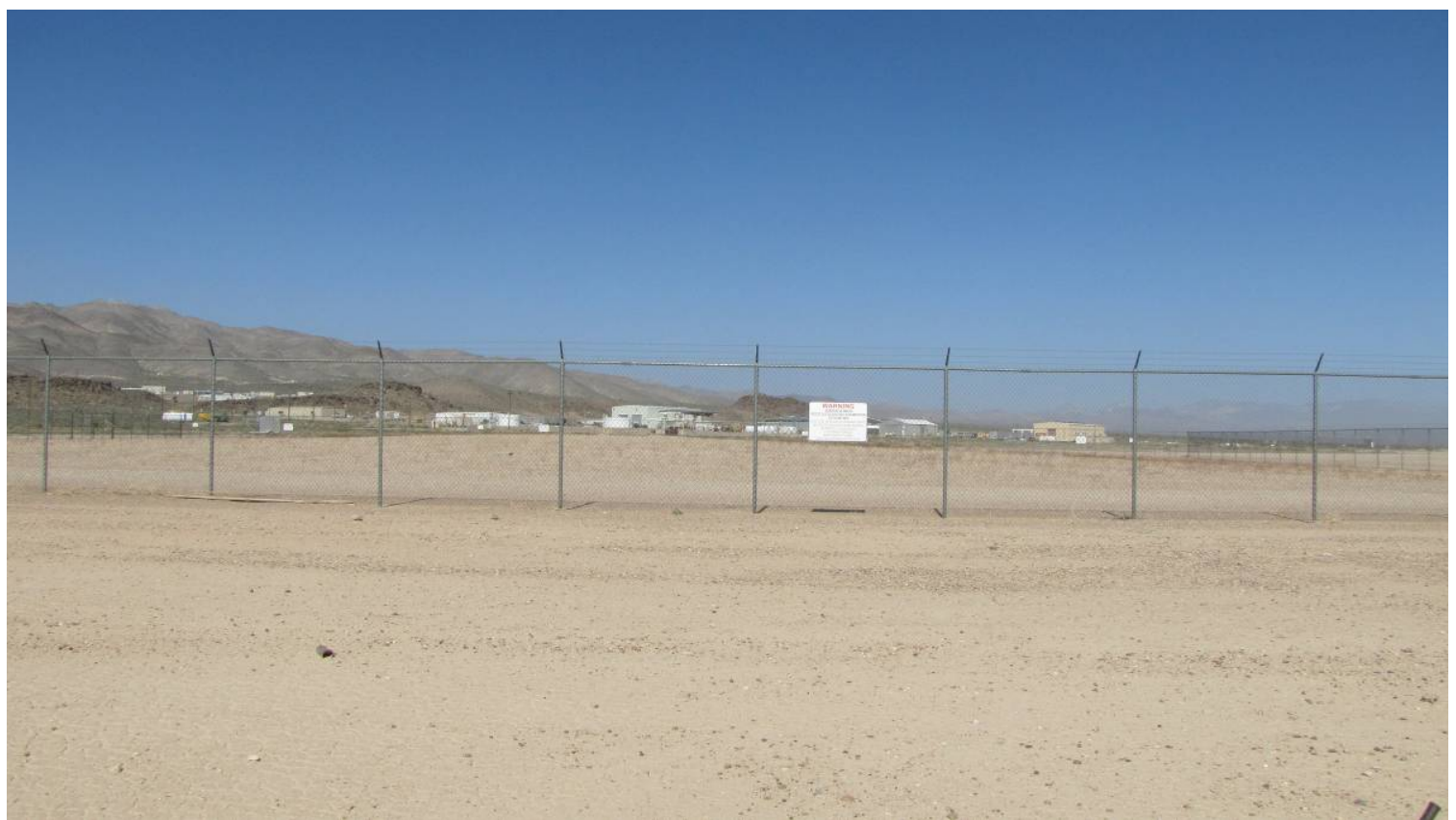

Photograph 56: CAU 92, Outside Facing West, 09/18/2013 


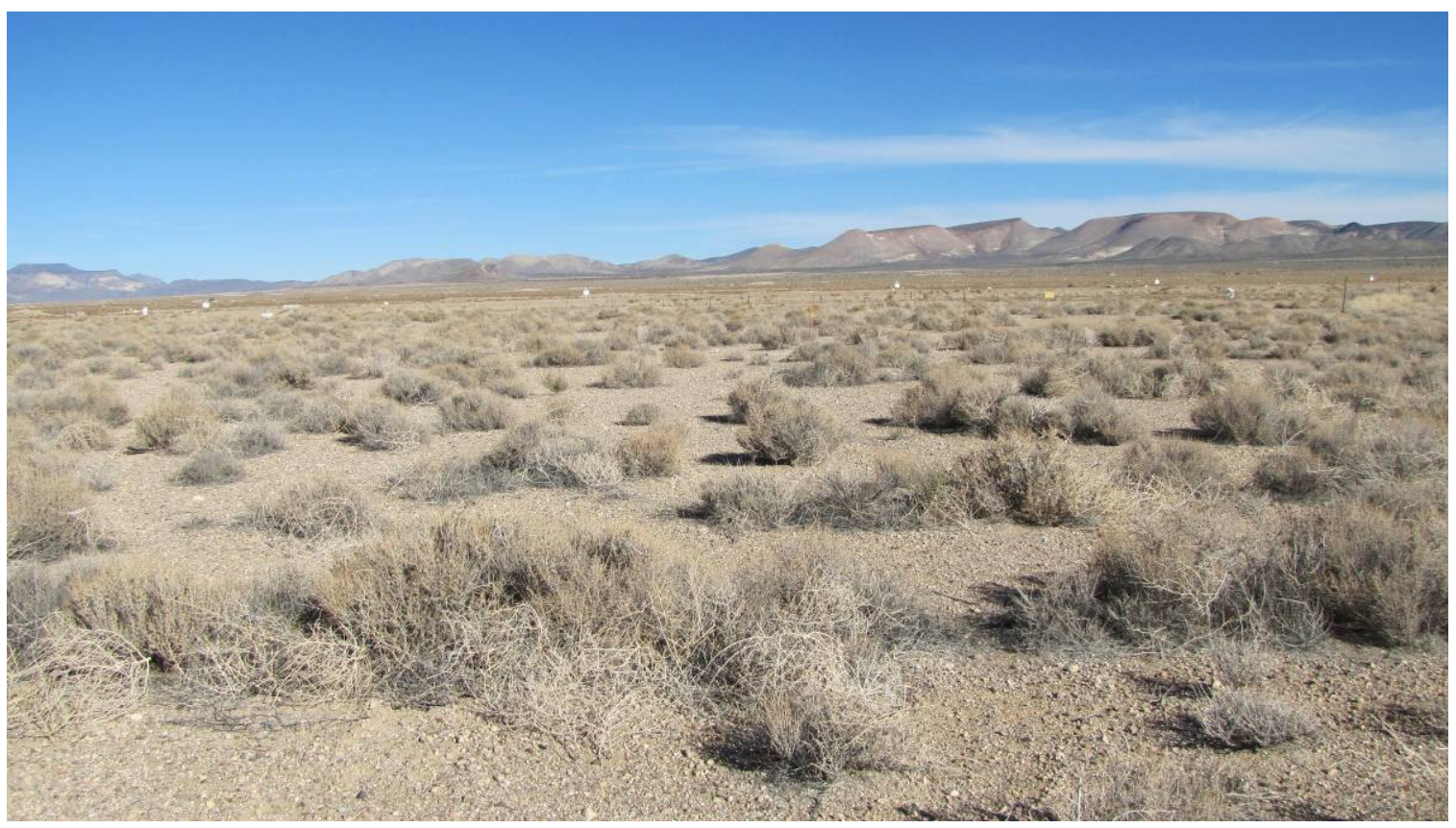

Photograph 57: CAU 110, Inside Facing North, 12/11/2012

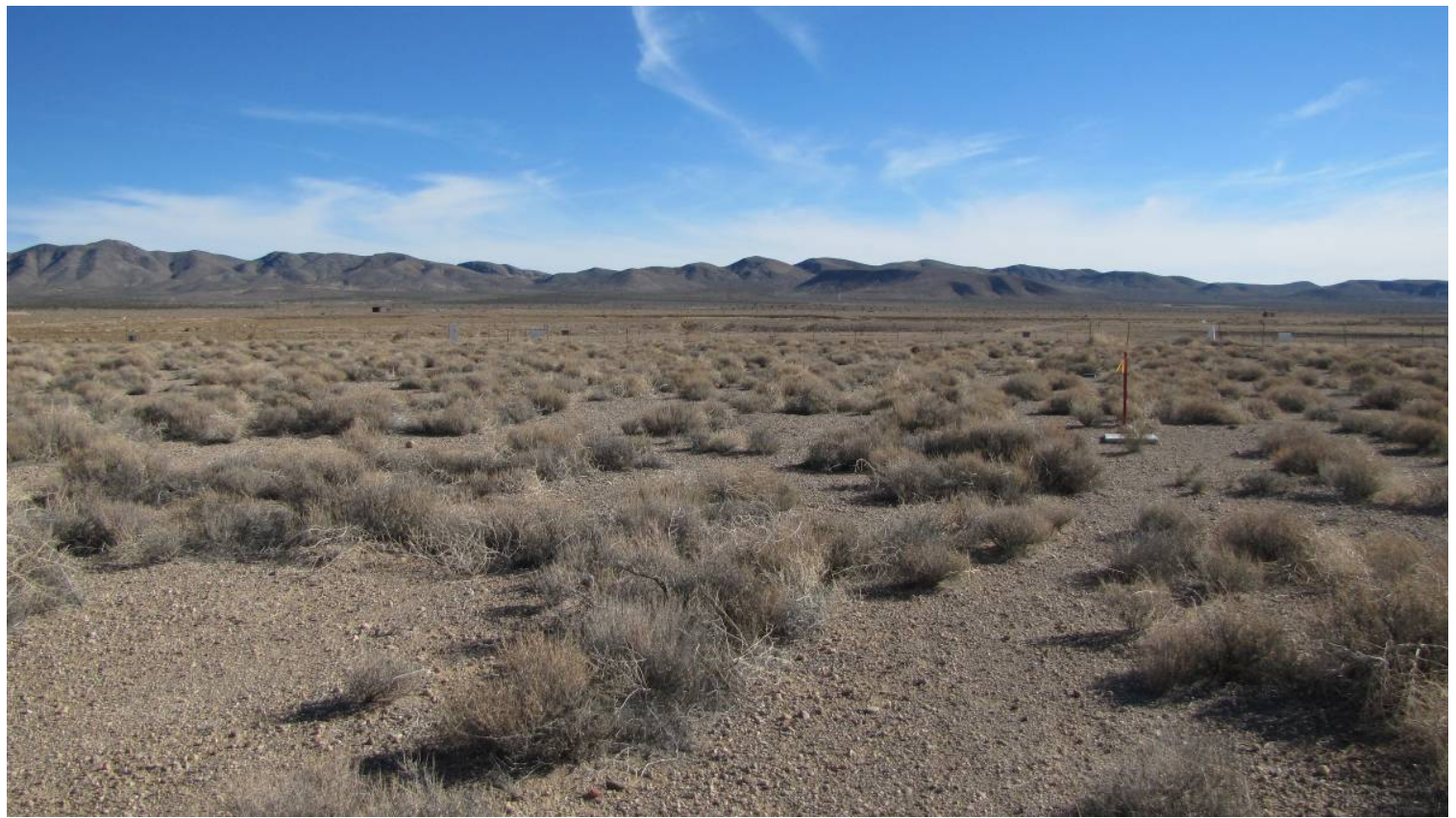

Photograph 58: CAU 110, Inside Facing East, 12/11/2012 
RCRA Post-Closure Report

Date: January 2014

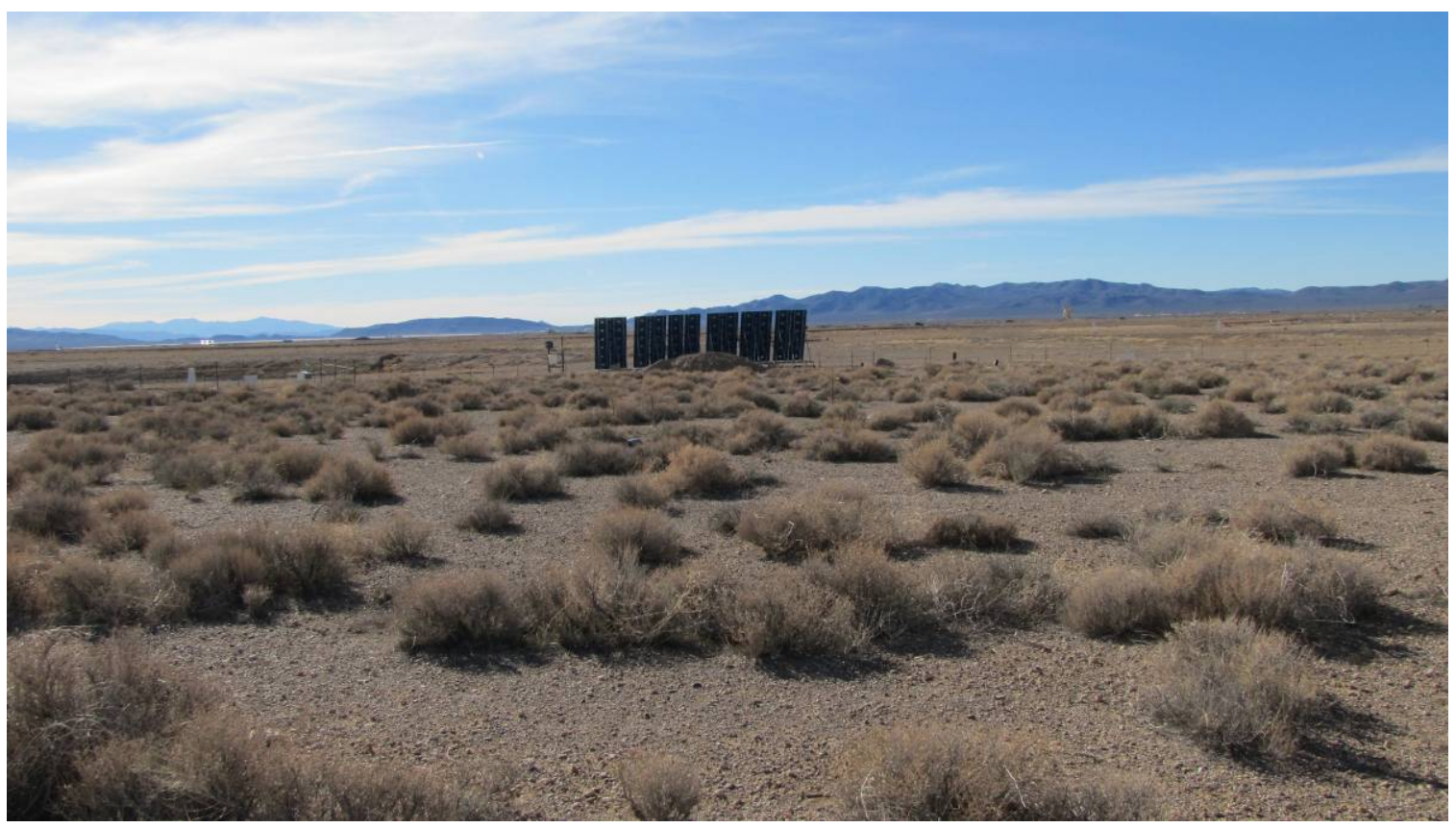

Photograph 59: CAU 110, Inside Facing South, 12/11/2012

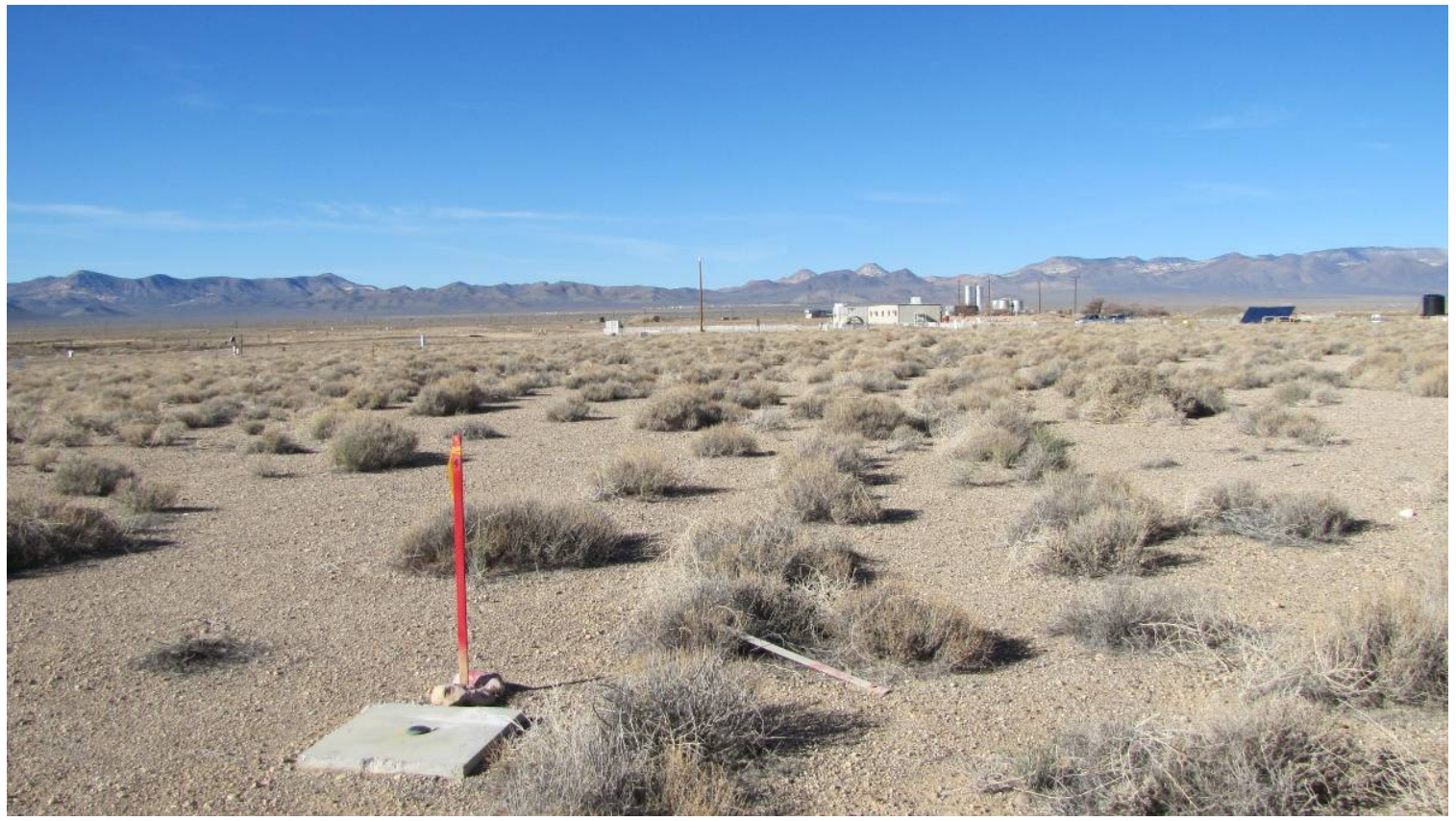

Photograph 60: CAU 110, Inside Facing West, 12/11/2012 


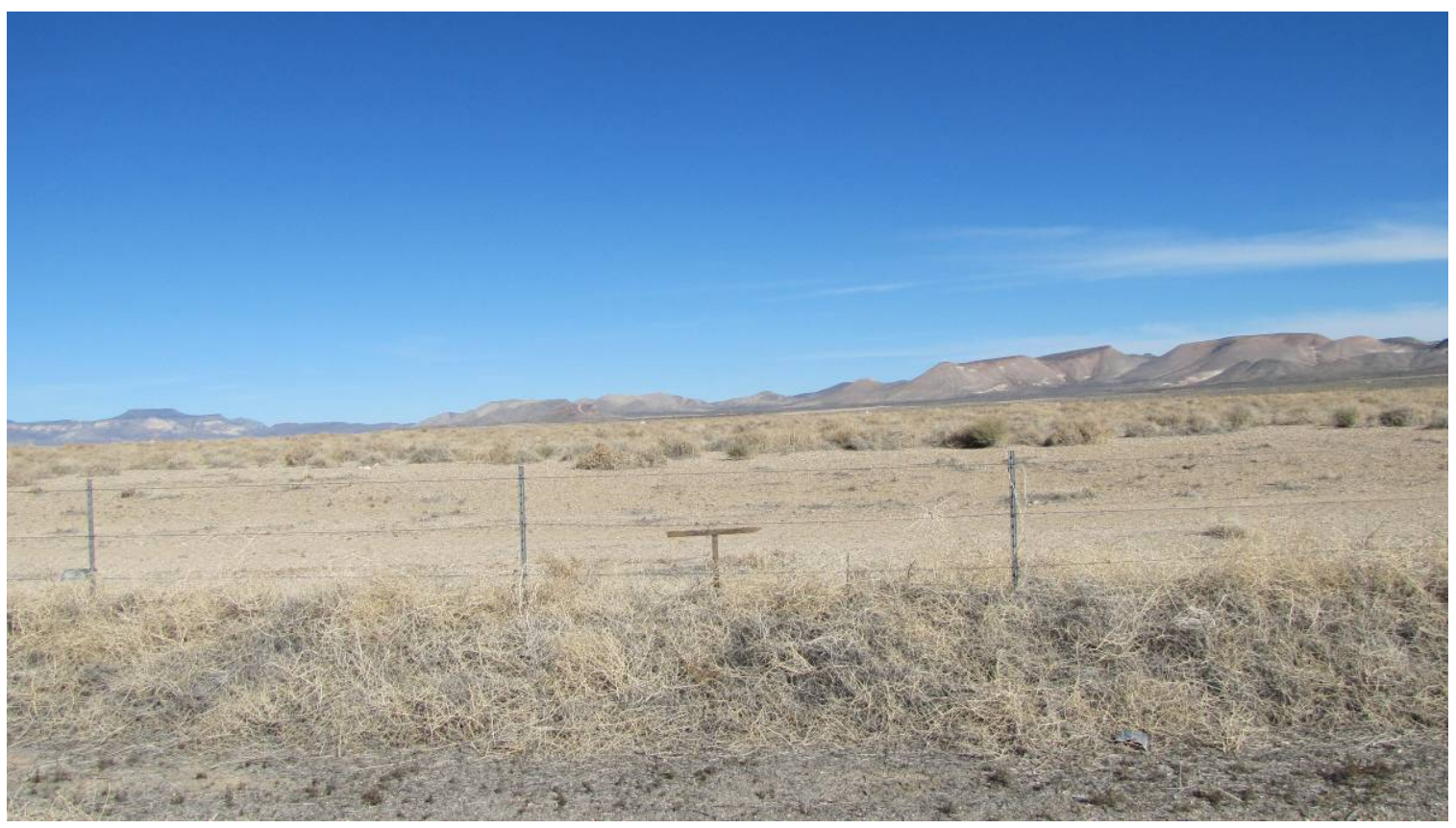

Photograph 61: CAU 110, Outside Facing North, 12/11/2012

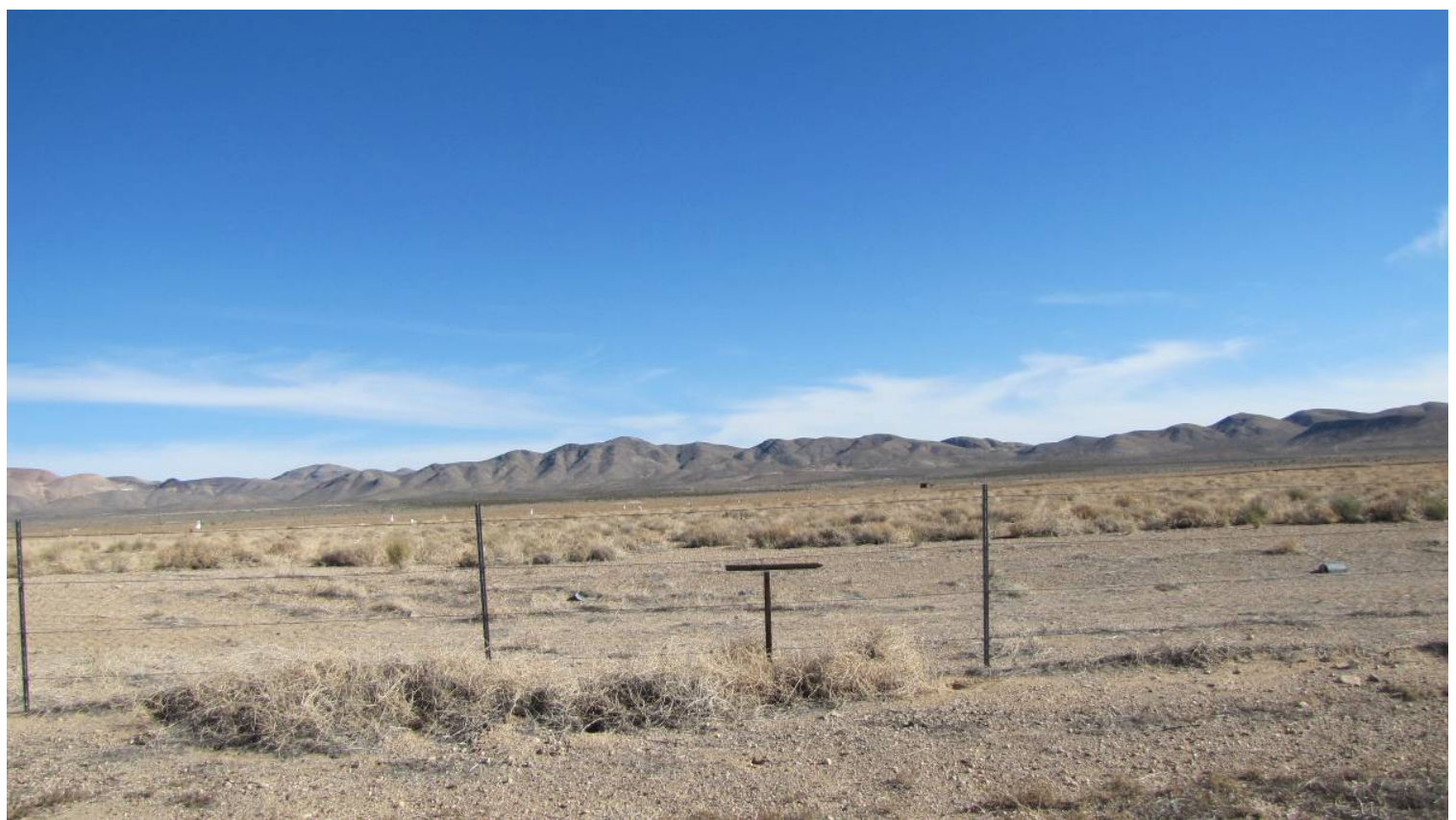

Photograph 62: CAU 110, Outside Facing East, 12/11/2012 


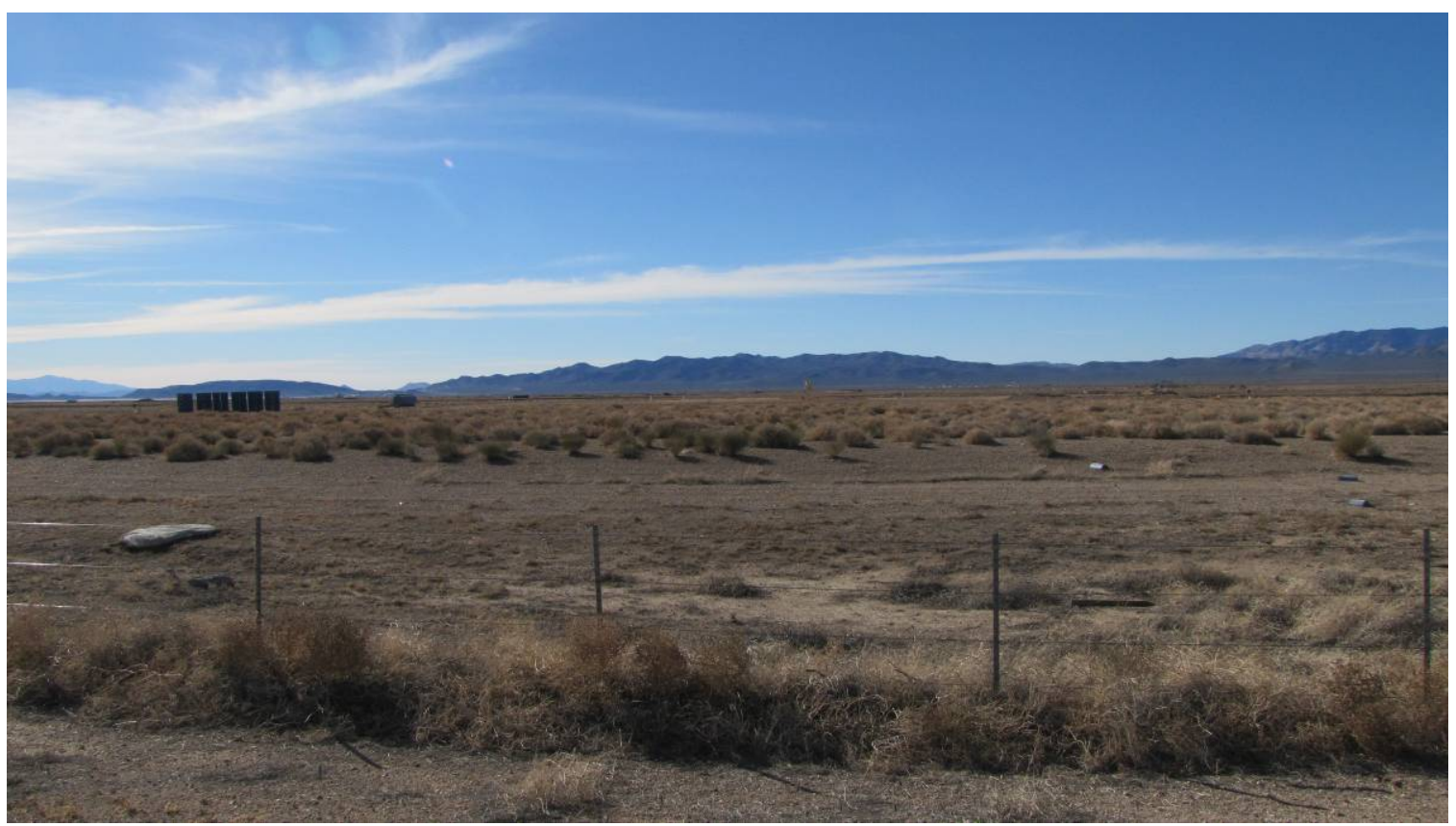

Photograph 63: CAU 110, Outside Facing South, 12/11/2012

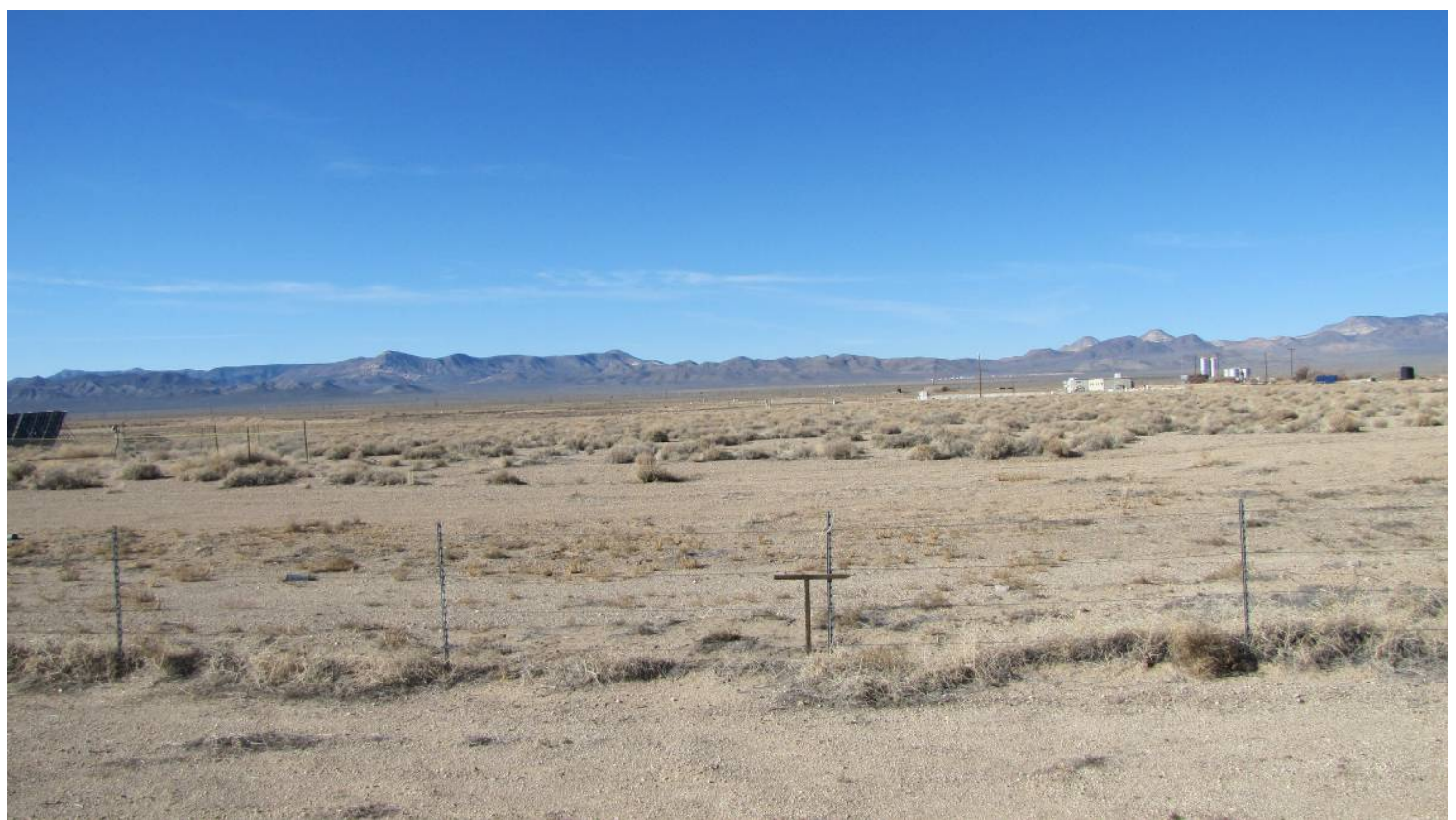

Photograph 64: CAU 110, Outside Facing West, 12/11/2012 


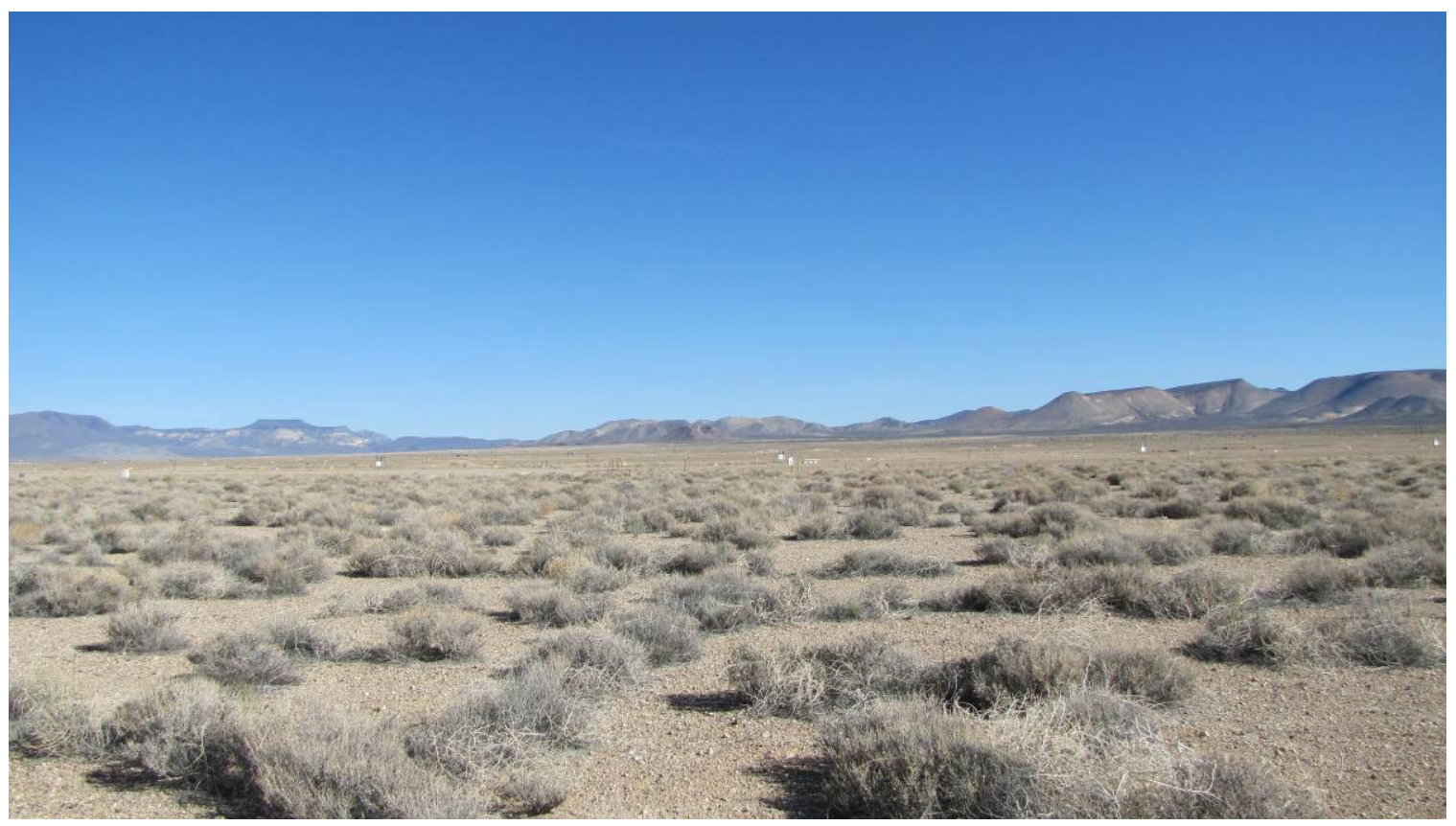

Photograph 65: CAU 110, Inside Facing North, 03/12/2013

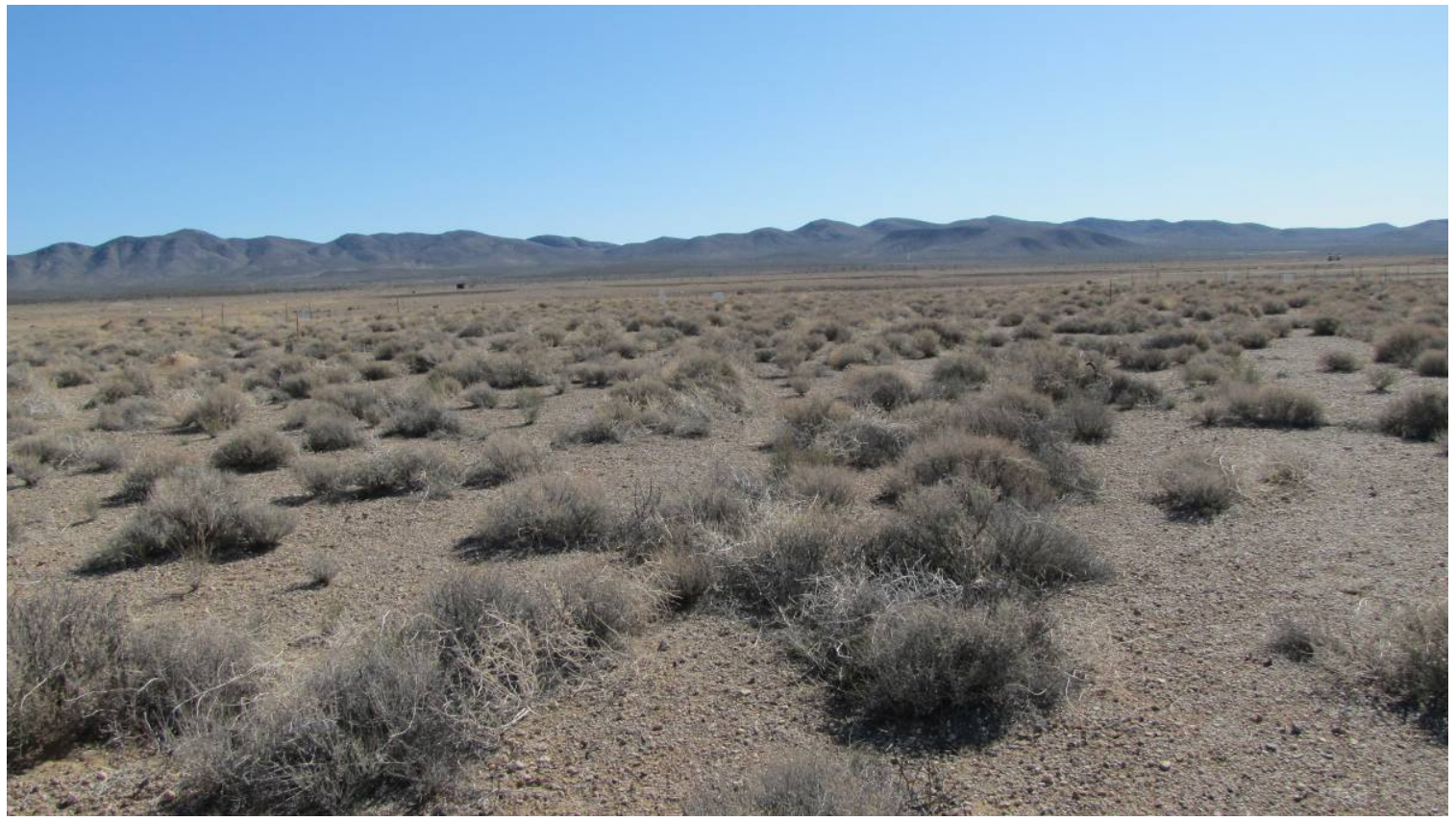

Photograph 66: CAU 110, Inside Facing East, 03/12/2013 


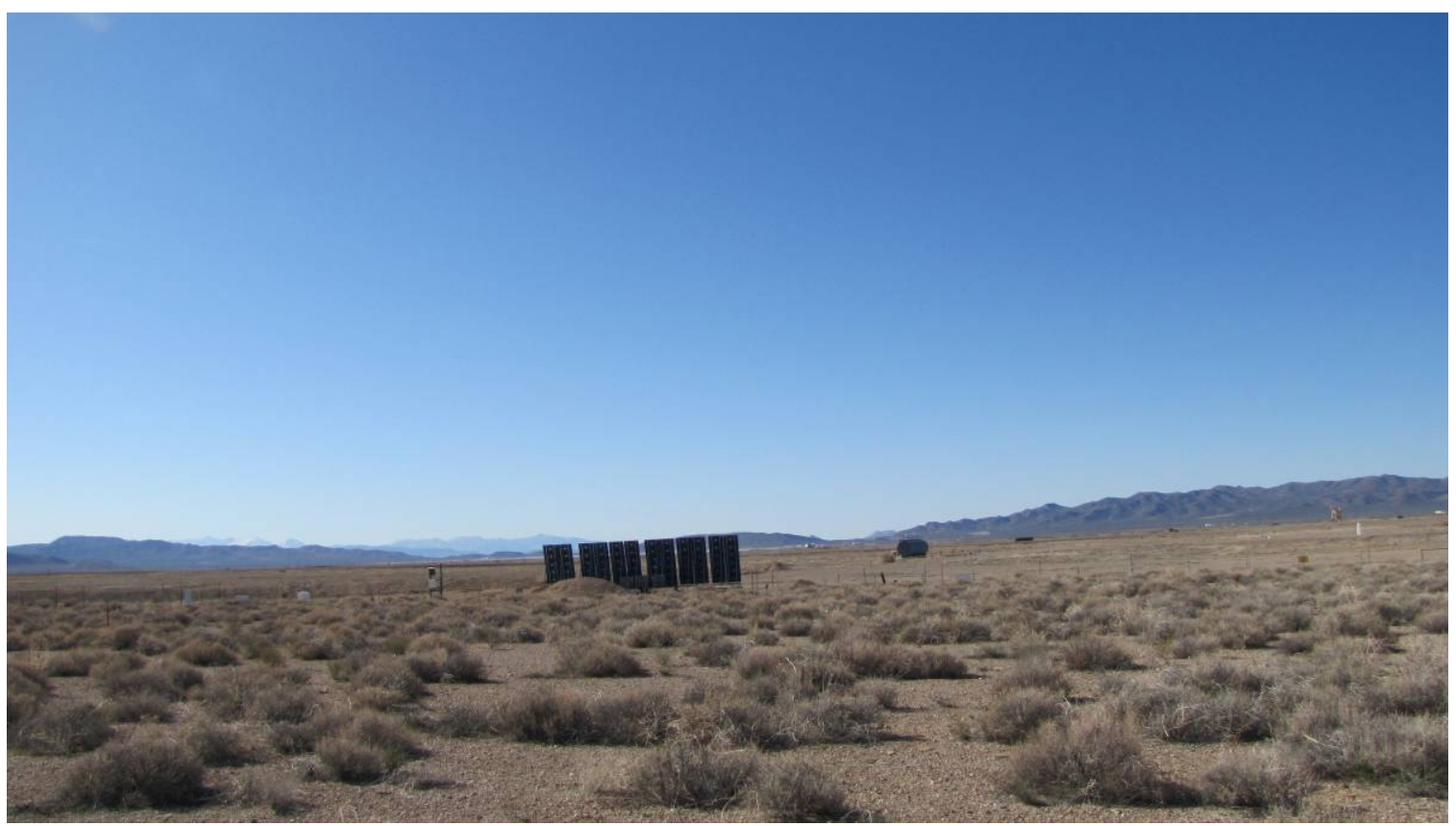

Photograph 67: CAU 110, Inside Facing South, 03/12/2013

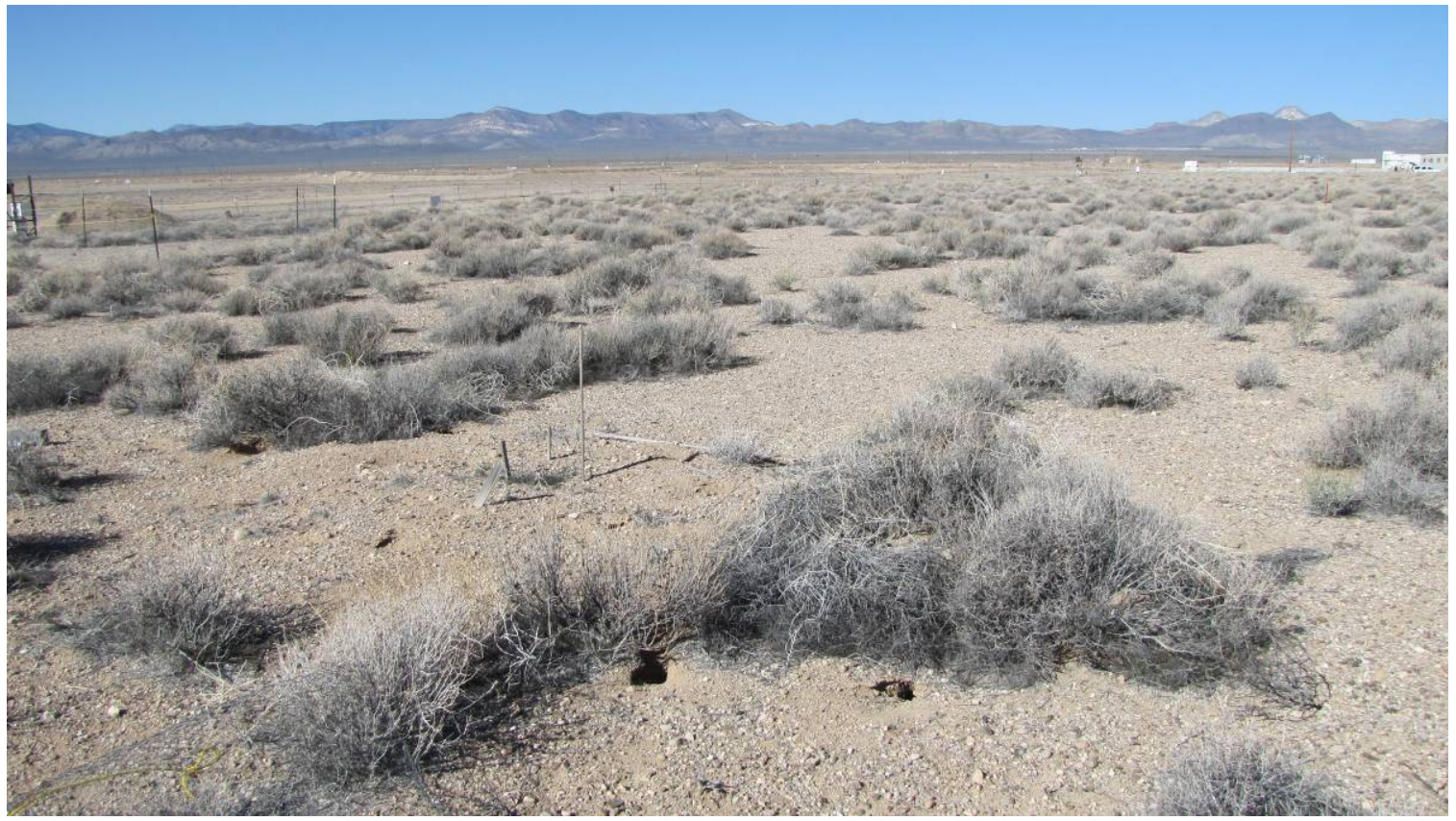

Photograph 68: CAU 110, Inside Facing West, 03/12/2013 


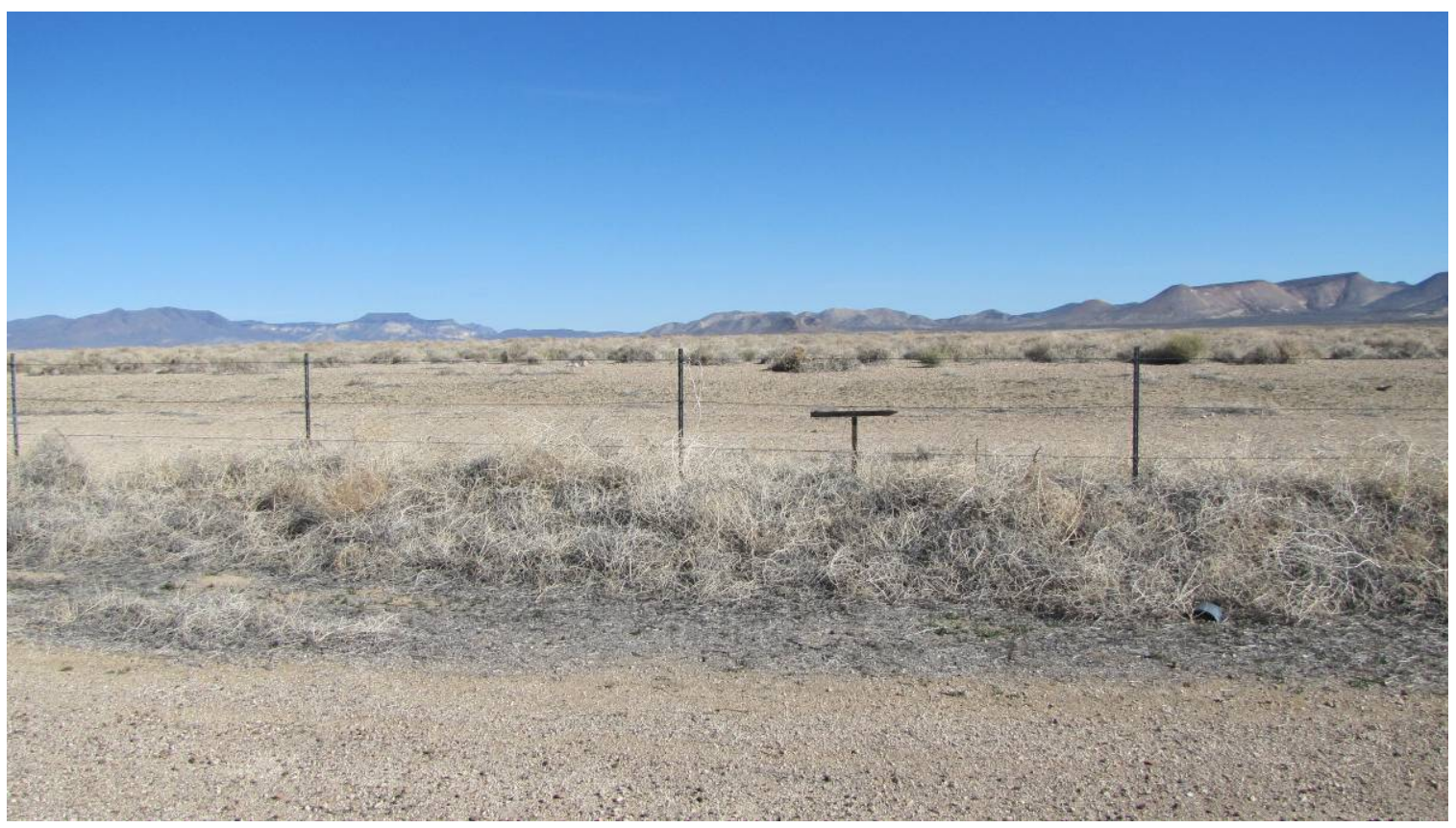

Photograph 69: CAU 110, Outside Facing North, 03/12/2013

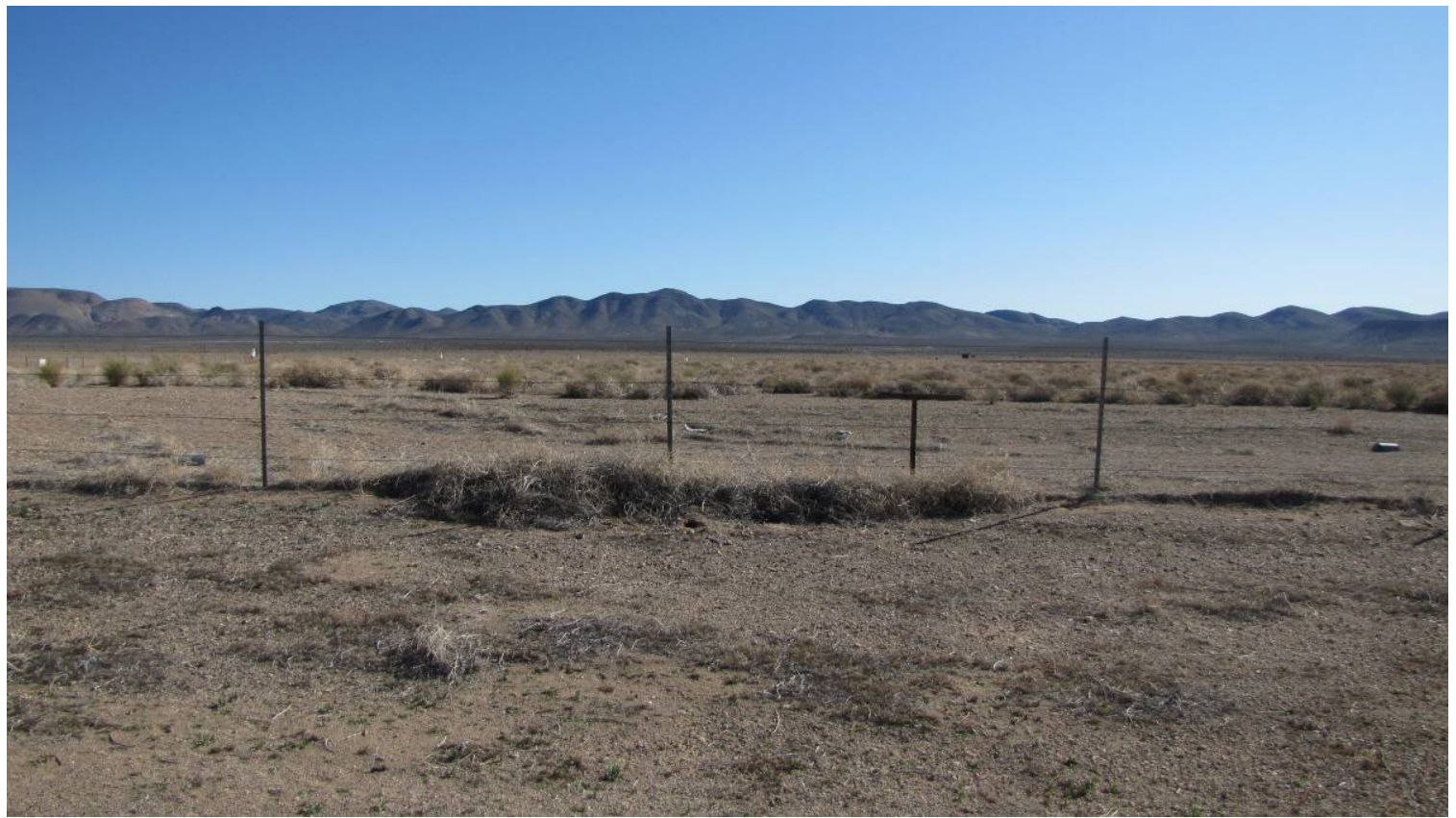

Photograph 70: CAU 110, Outside Facing East, 03/12/2013 


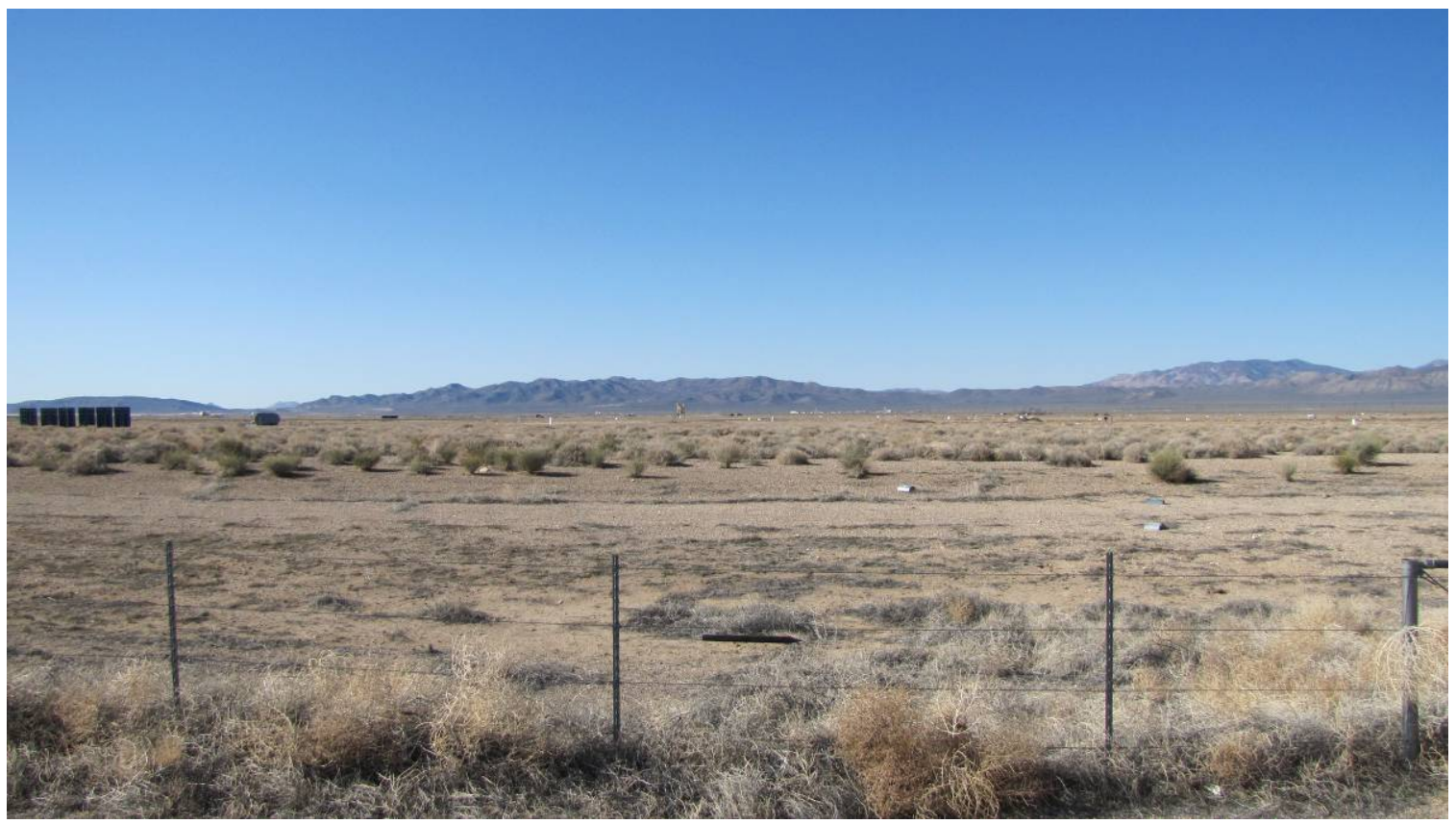

Photograph 71: CAU 110, Outside Facing South, 03/12/2013

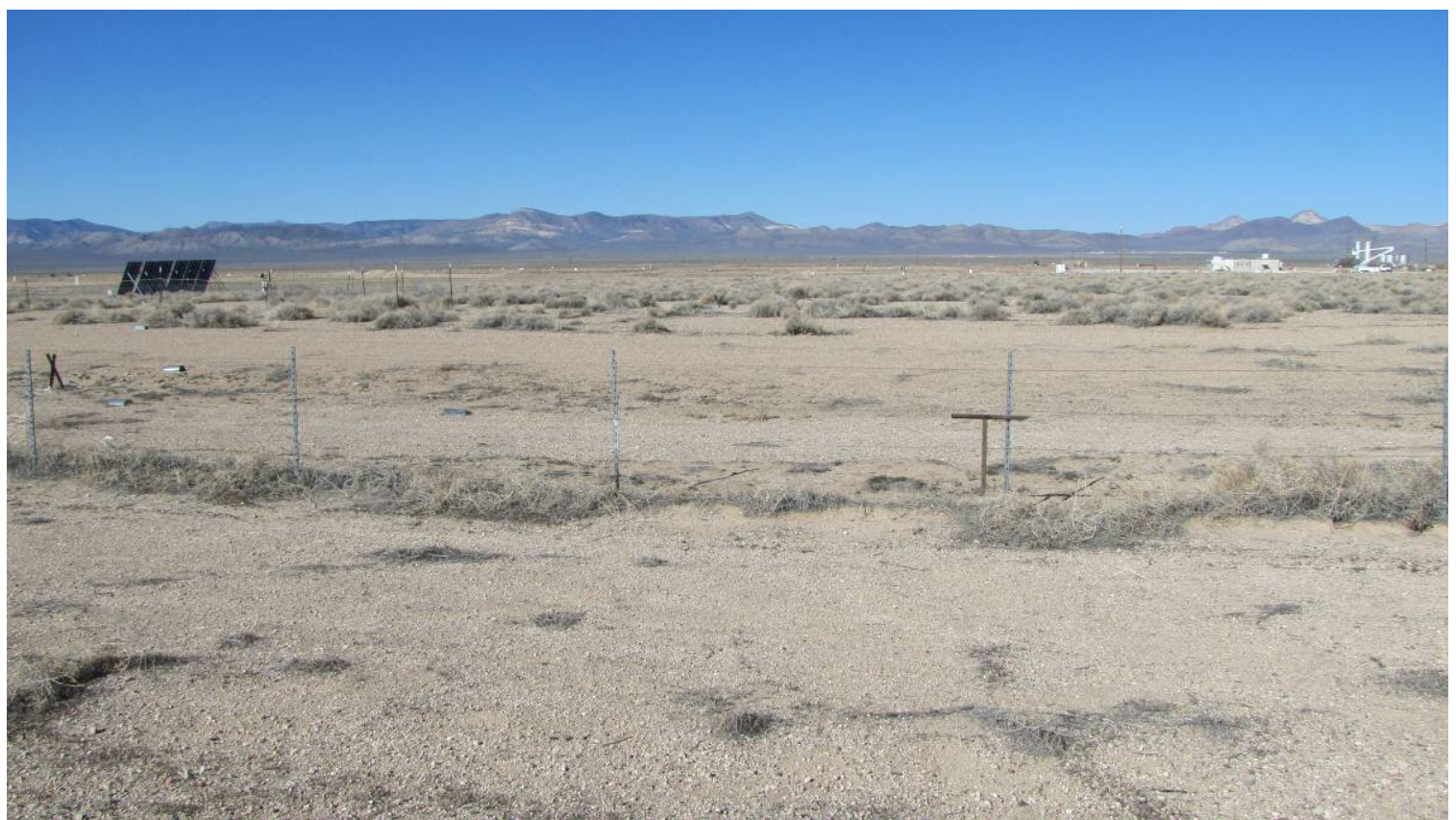

Photograph 72: CAU 110, Outside Facing West, 03/12/2013 
RCRA Post-Closure Report

Date: January 2014

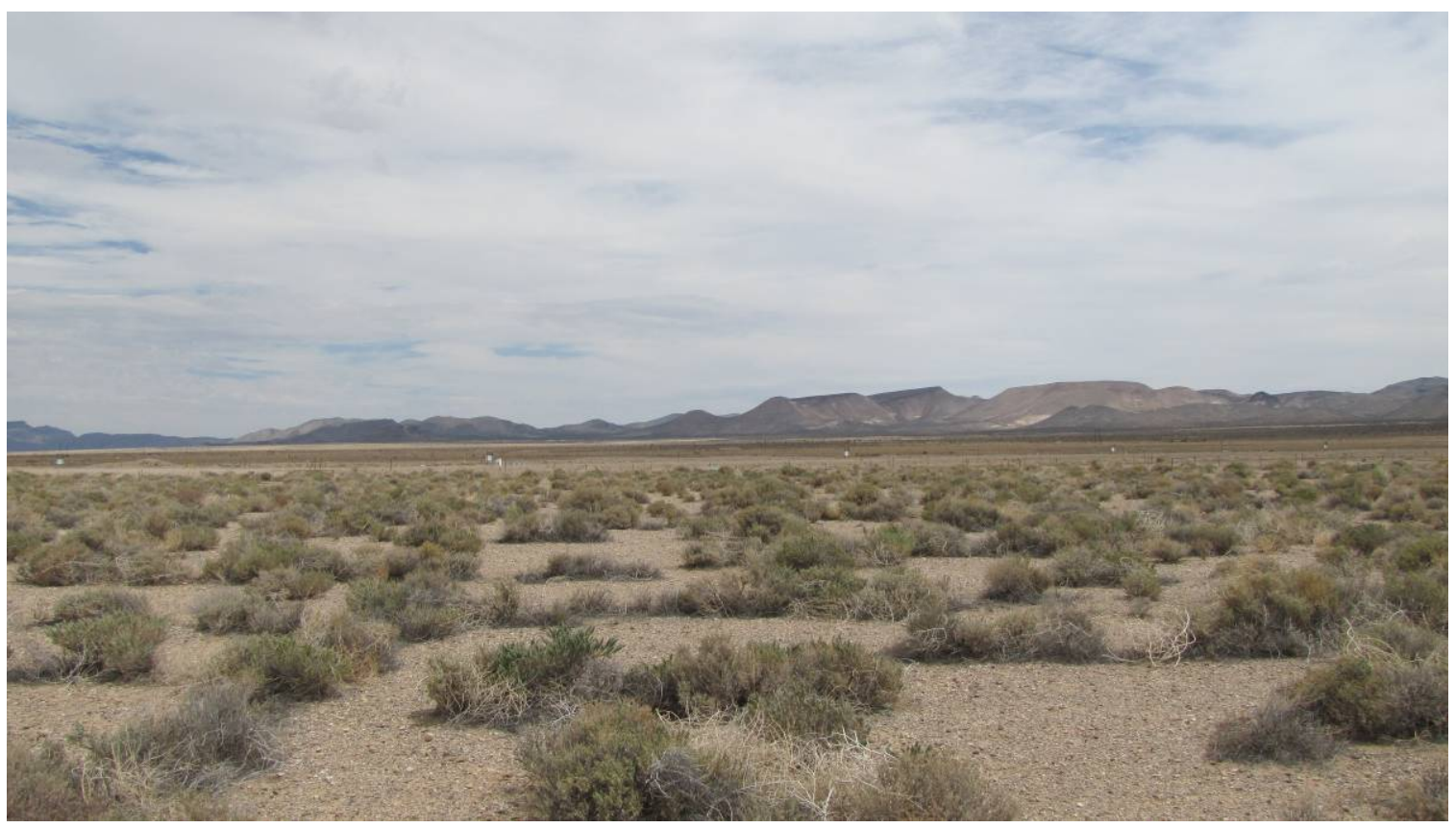

Photograph 73: CAU 110, Inside Facing North, 06/12/2013

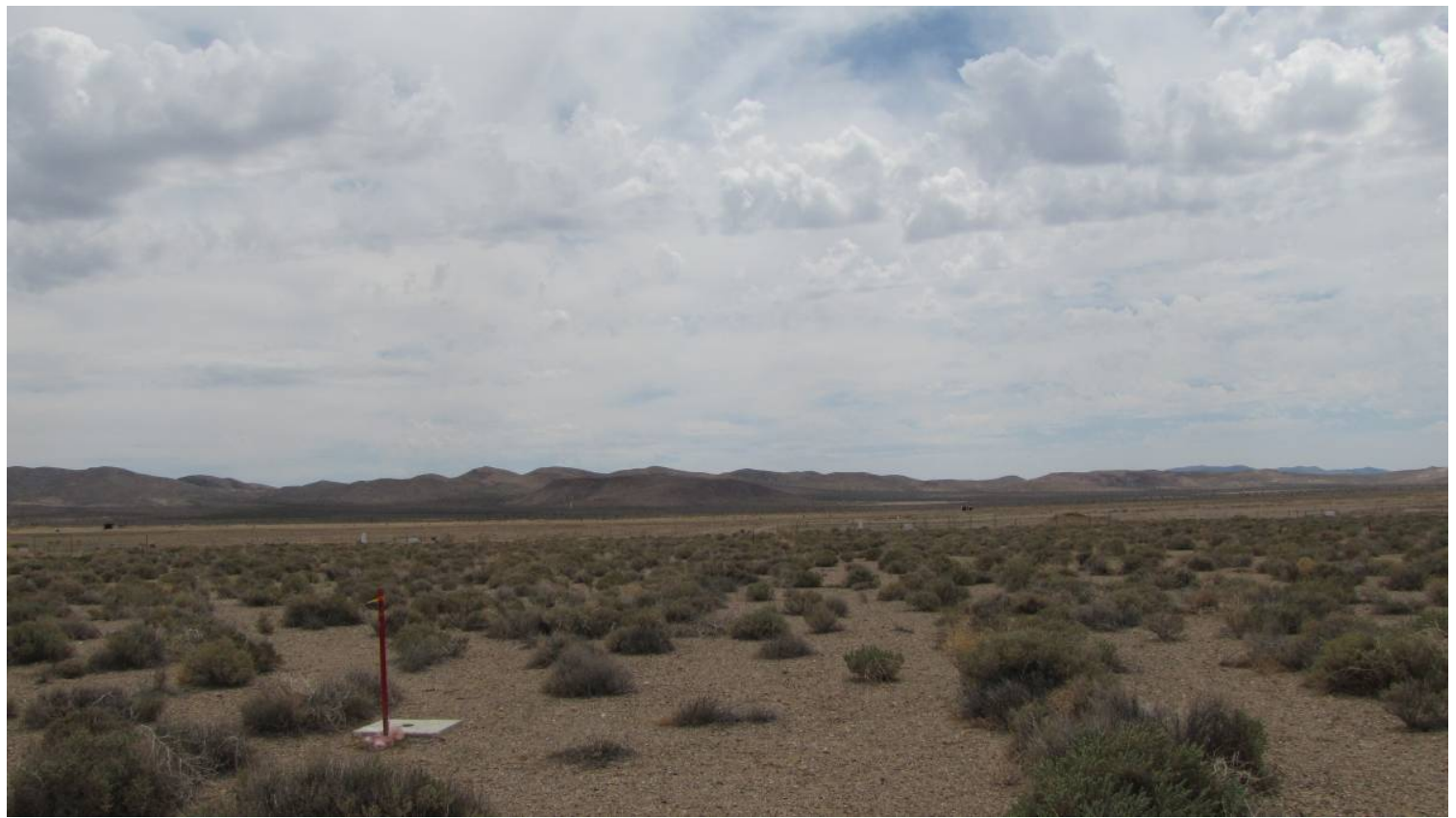

Photograph 74: CAU 110, Inside Facing East, 06/12/2013 
RCRA Post-Closure Report

Date: January 2014

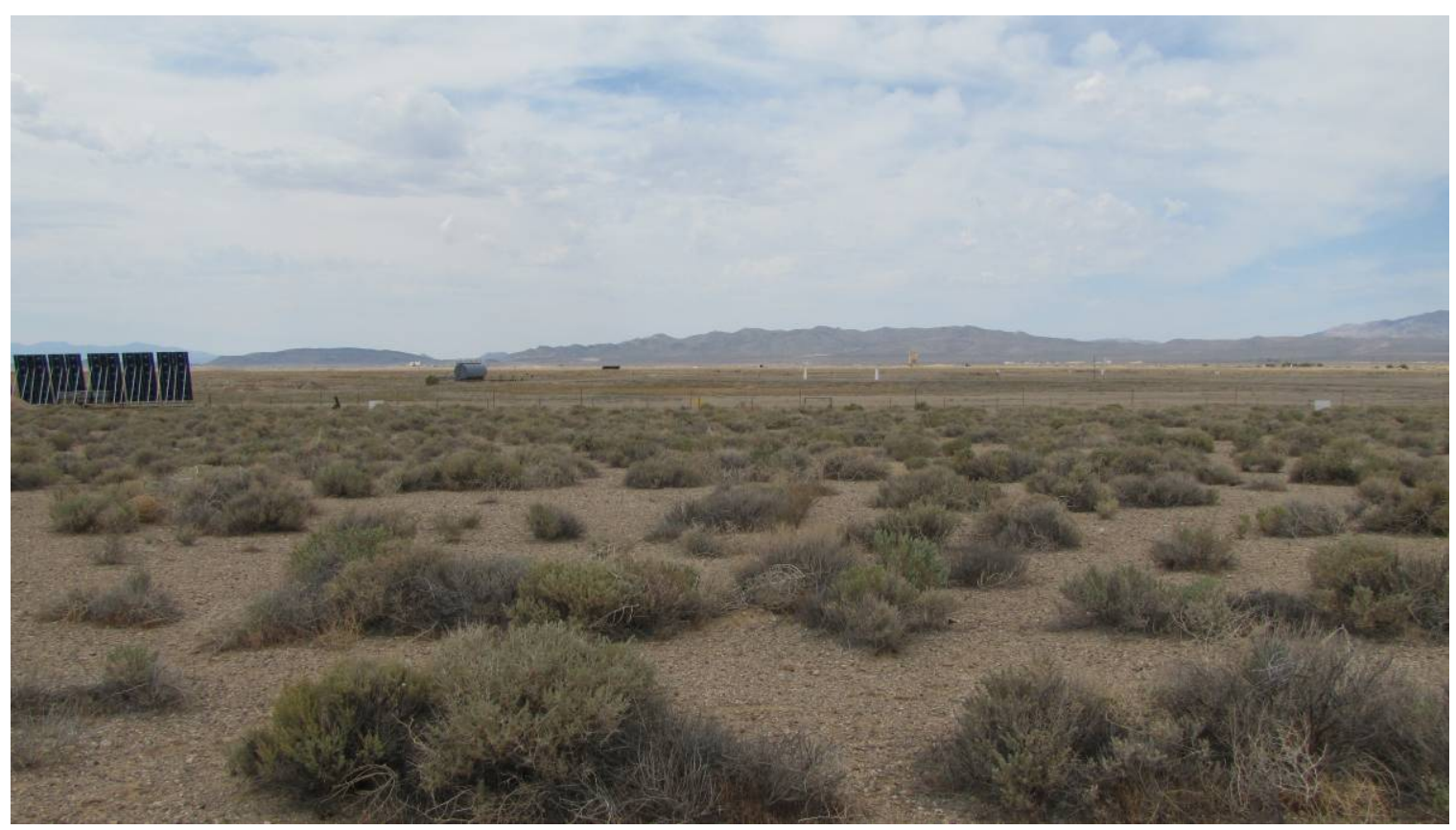

Photograph 75: CAU 110, Inside Facing South, 06/12/2013

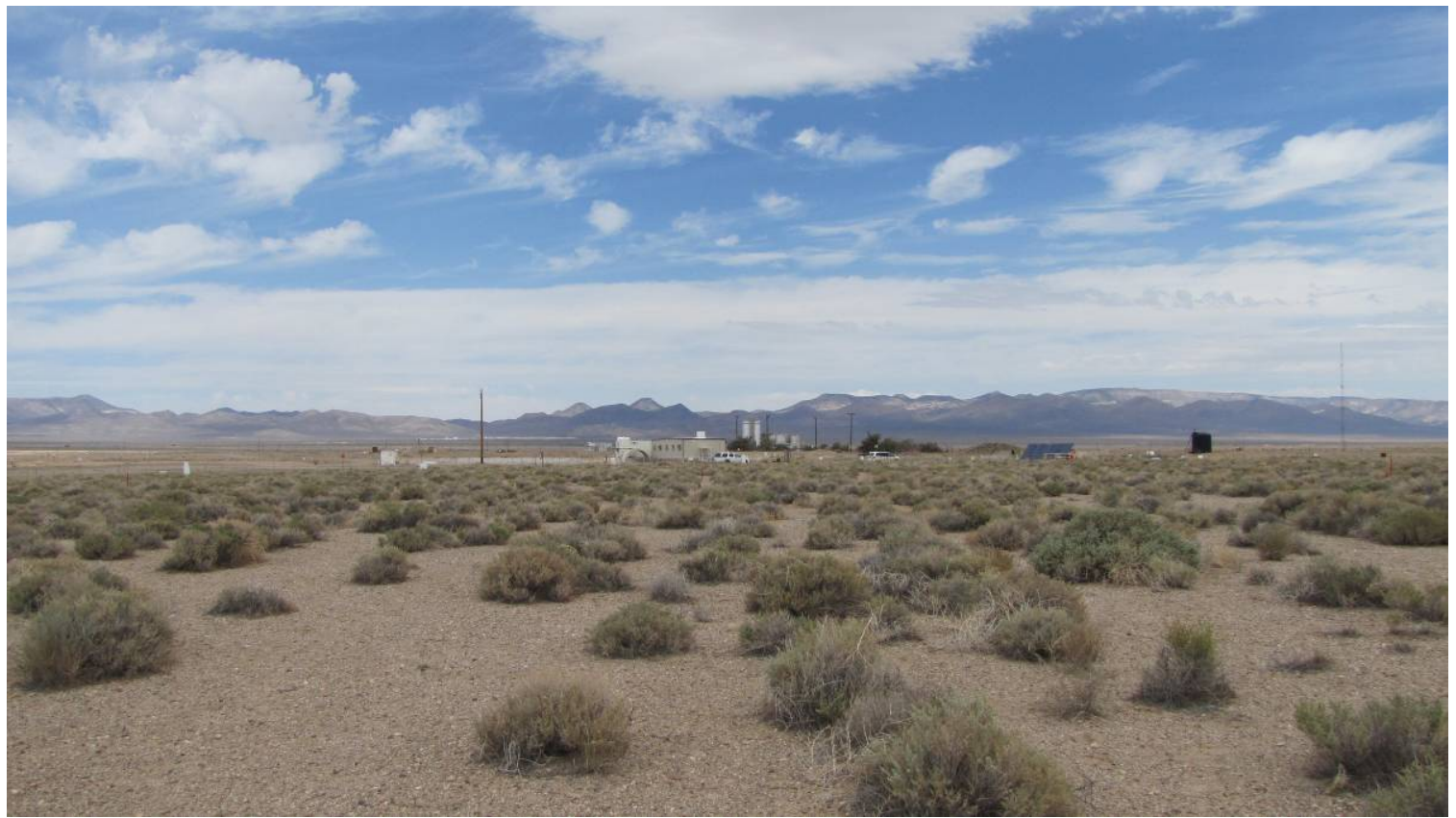

Photograph 76: CAU 110, Inside Facing West, 06/12/2013 
RCRA Post-Closure Report

Revision: 0

Date: January 2014

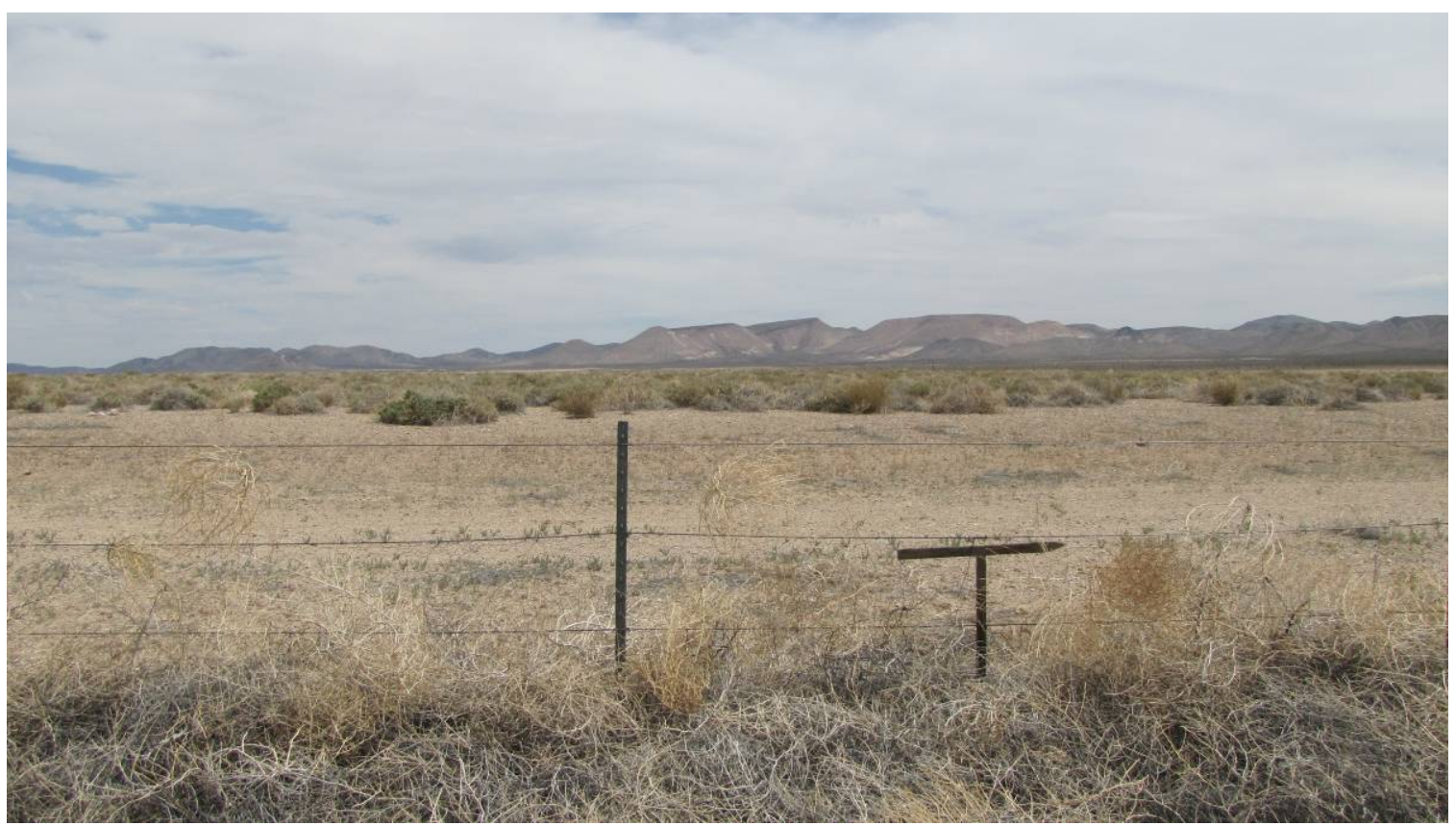

Photograph 77: CAU 110, Outside Facing North, 06/12/2013

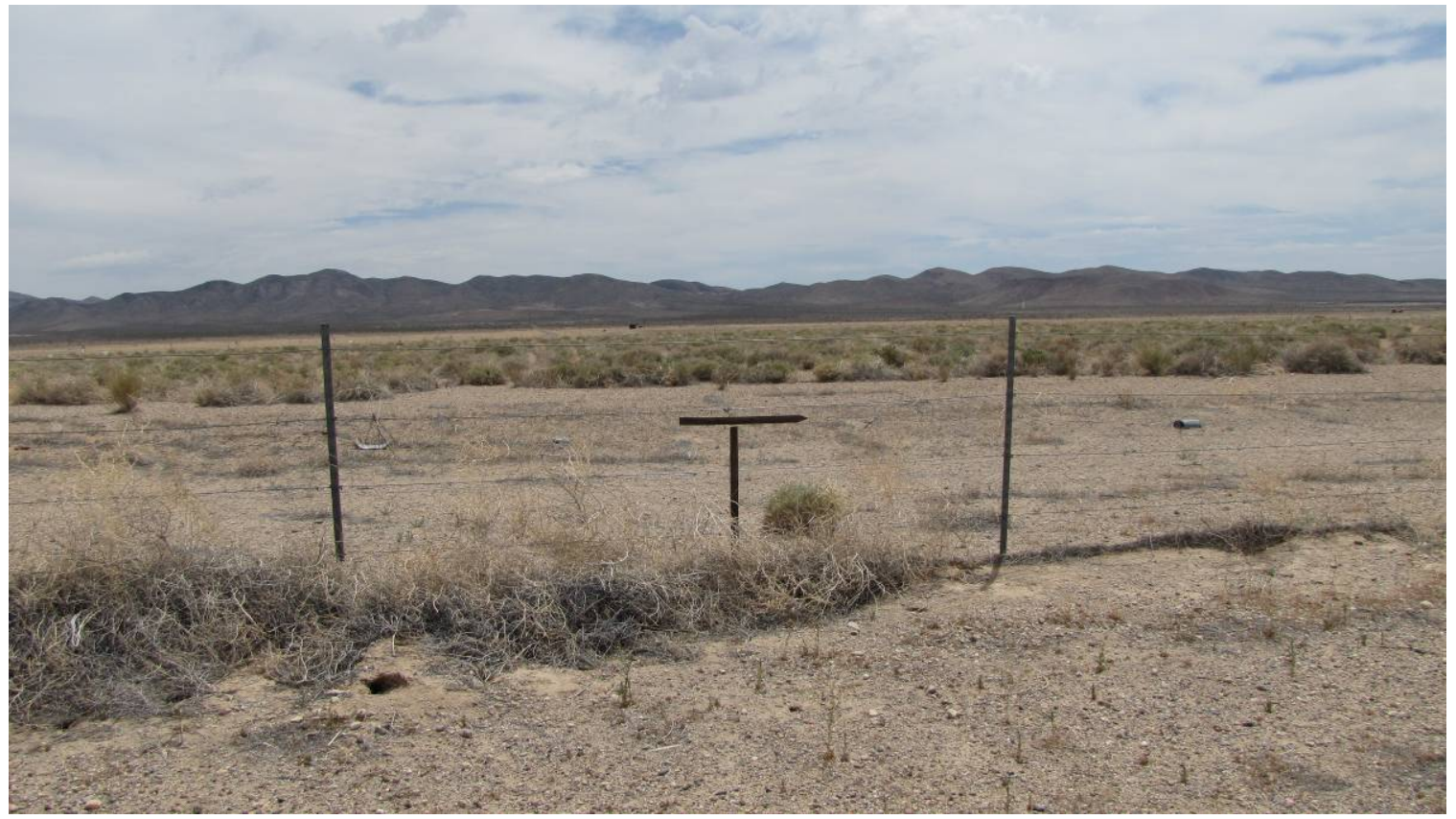

Photograph 78: CAU 110, Outside Facing East, 06/12/2013 


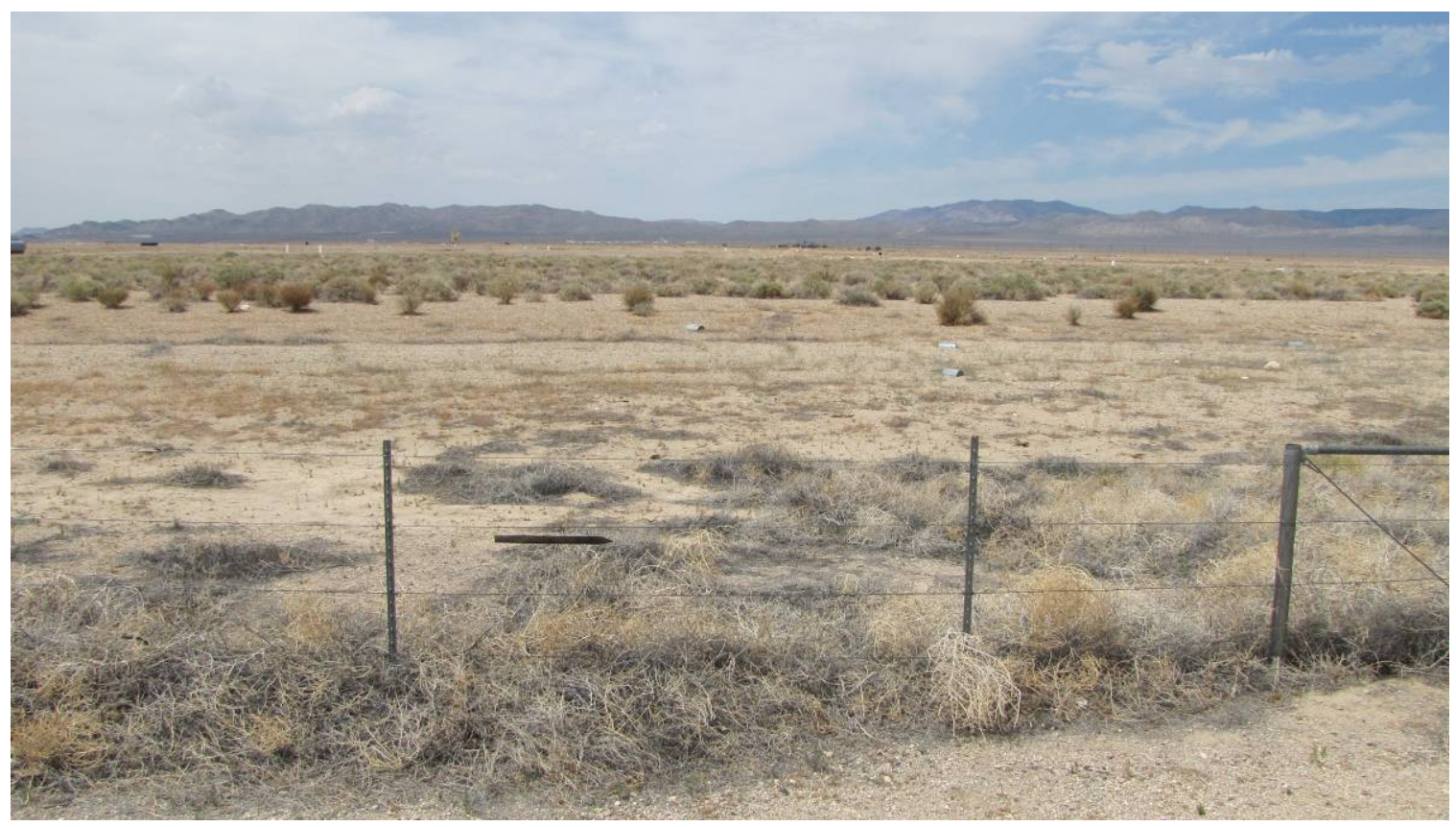

Photograph 79: CAU 110, Outside Facing South, 06/12/2013

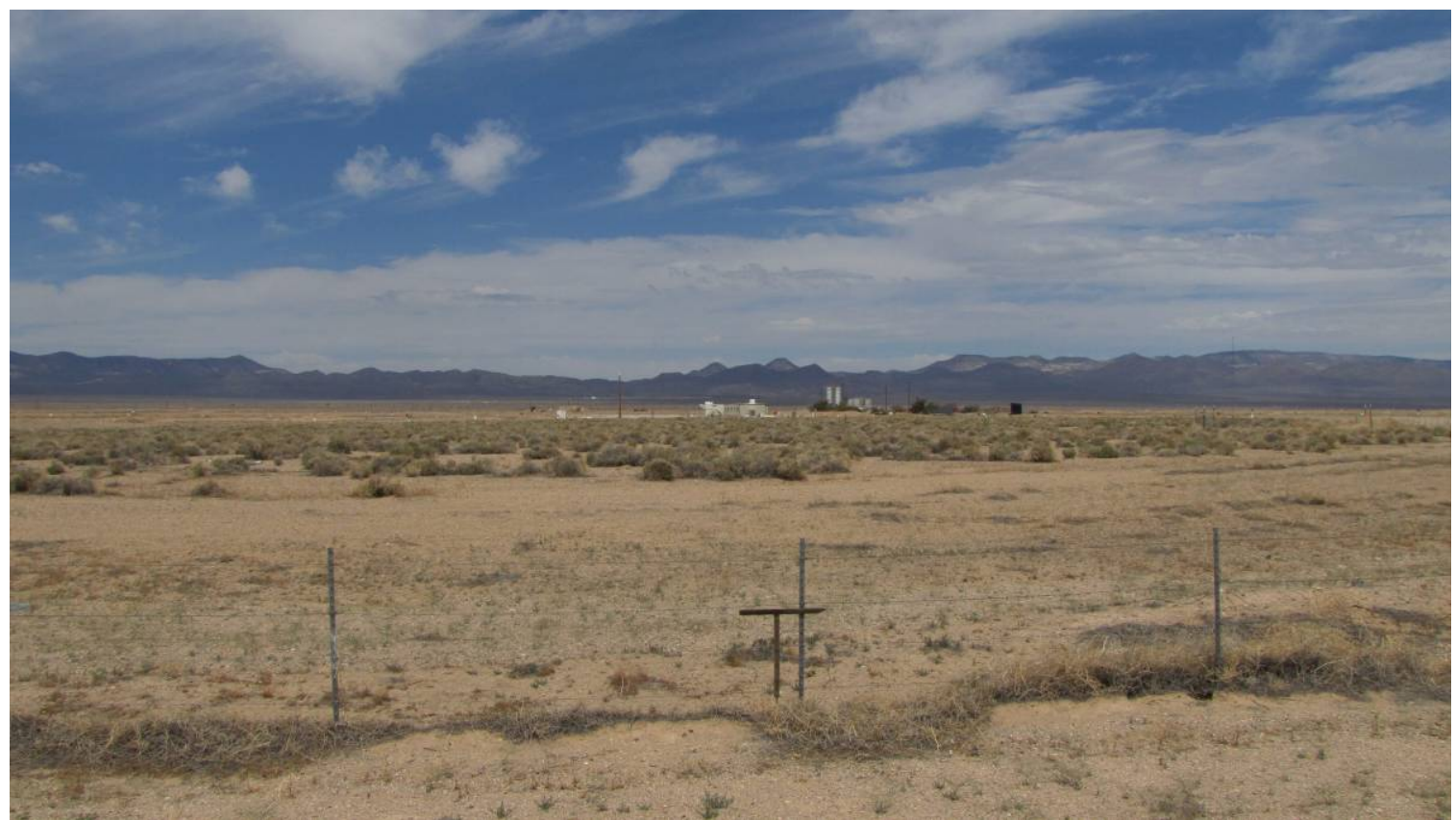

Photograph 80: CAU 110, Outside Facing West, 06/12/2013 


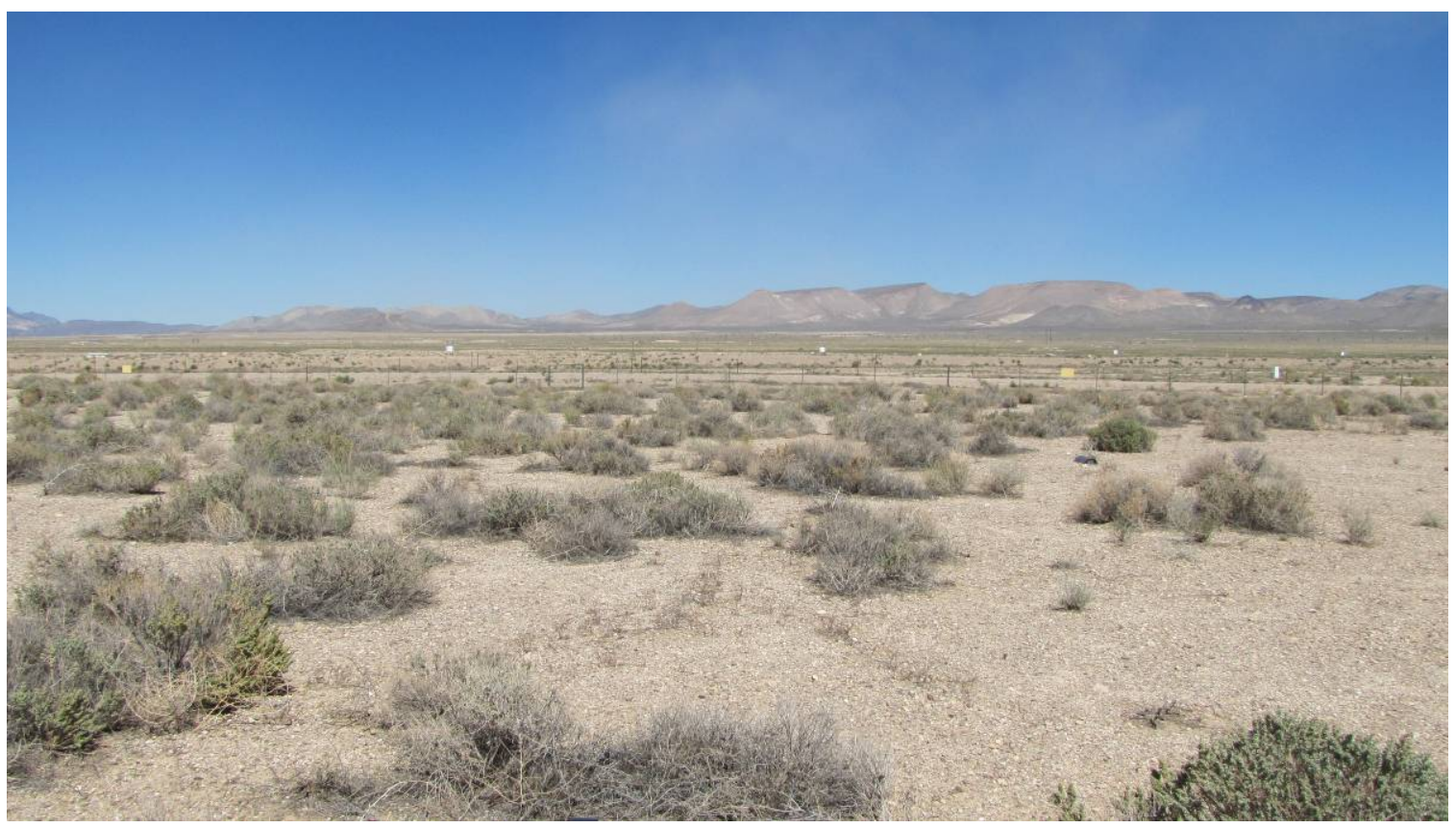

Photograph 81: CAU 110, Inside Facing North, 09/17/2013

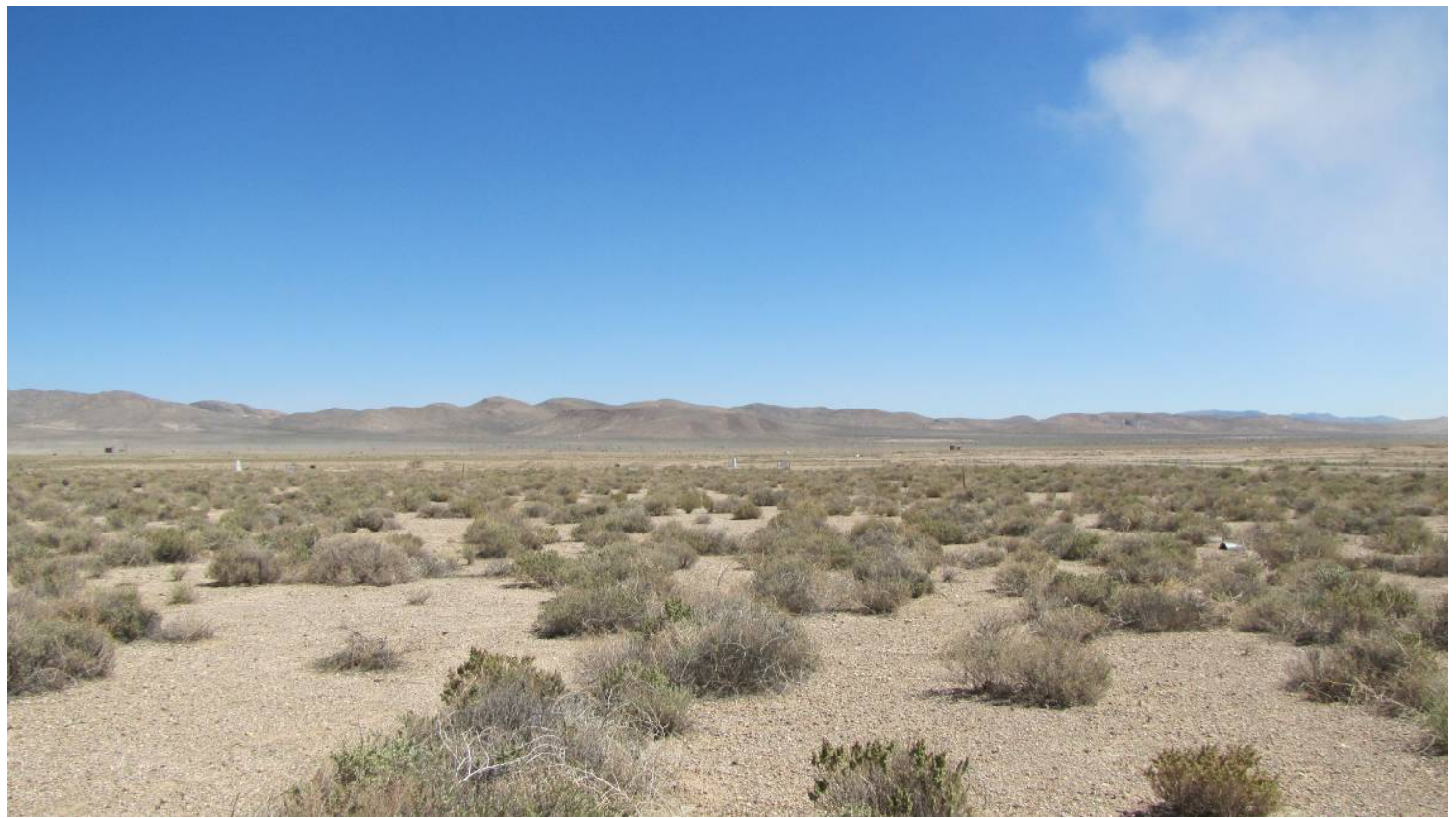

Photograph 82: CAU 110, Inside Facing East, 09/17/2013 


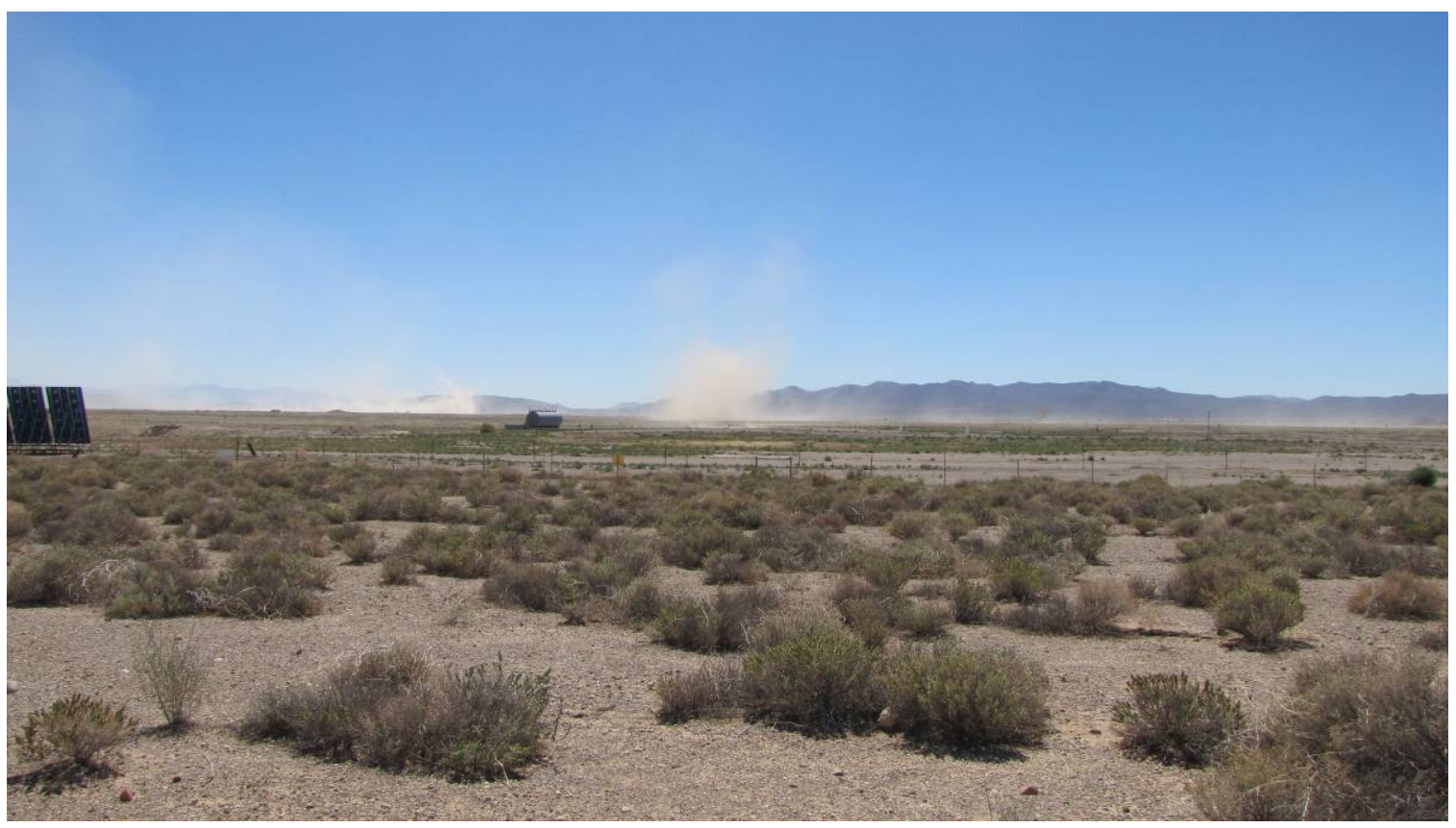

Photograph 83: CAU 110, Inside Facing South, 09/17/2013

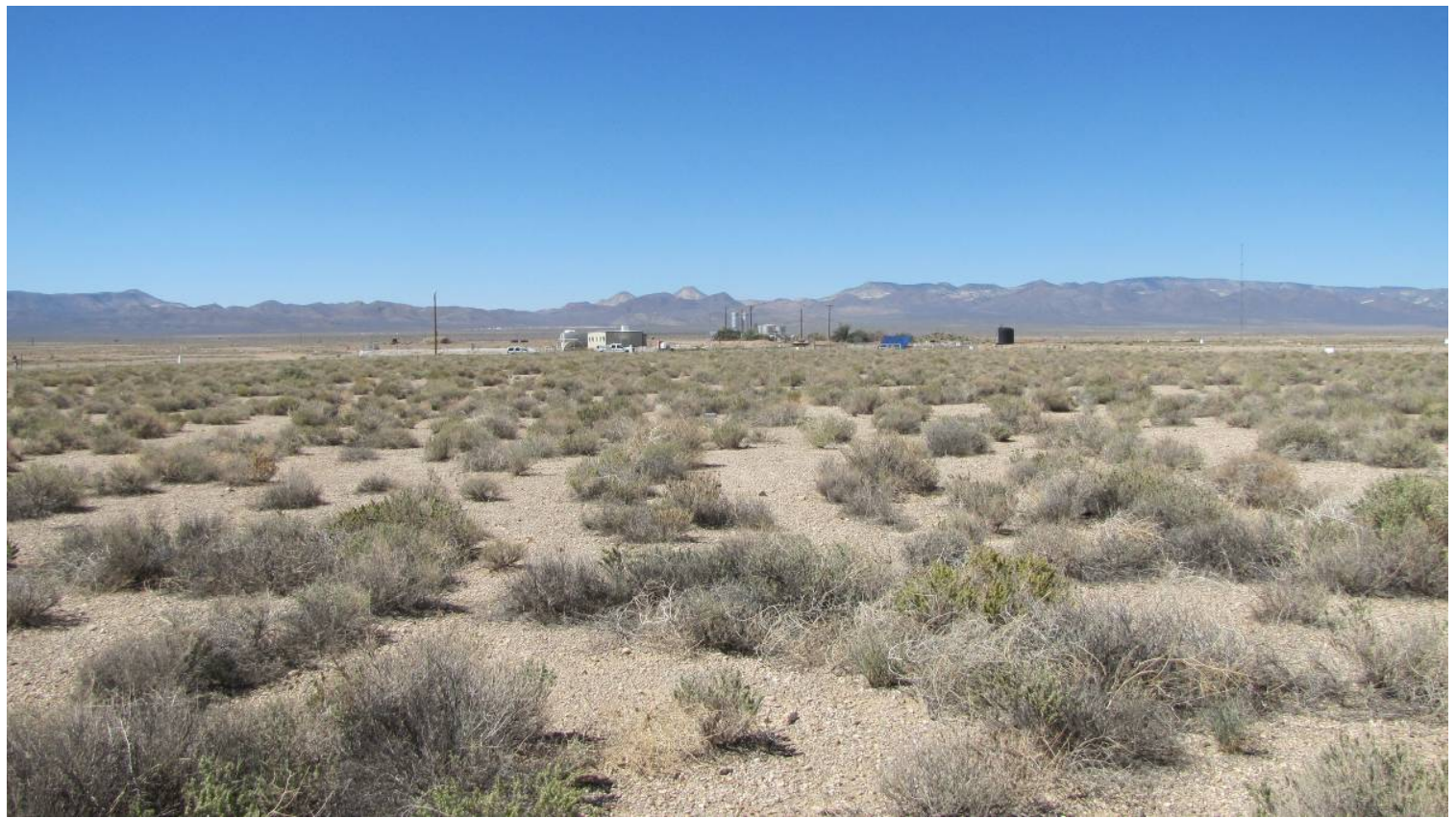

Photograph 84: CAU 110, Inside Facing West, 09/17/2013 


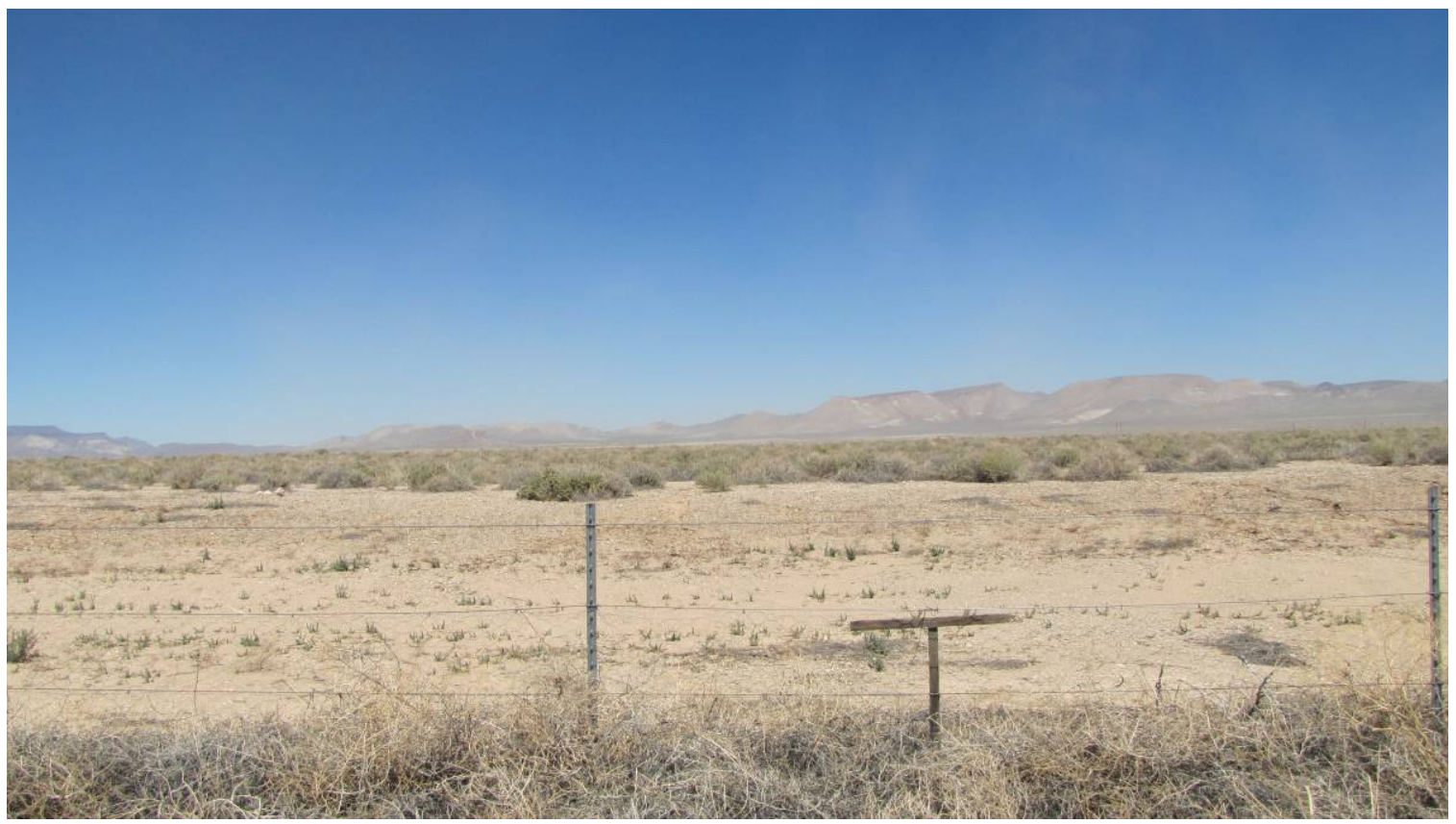

Photograph 85: CAU 110, Outside Facing North, 09/17/2013

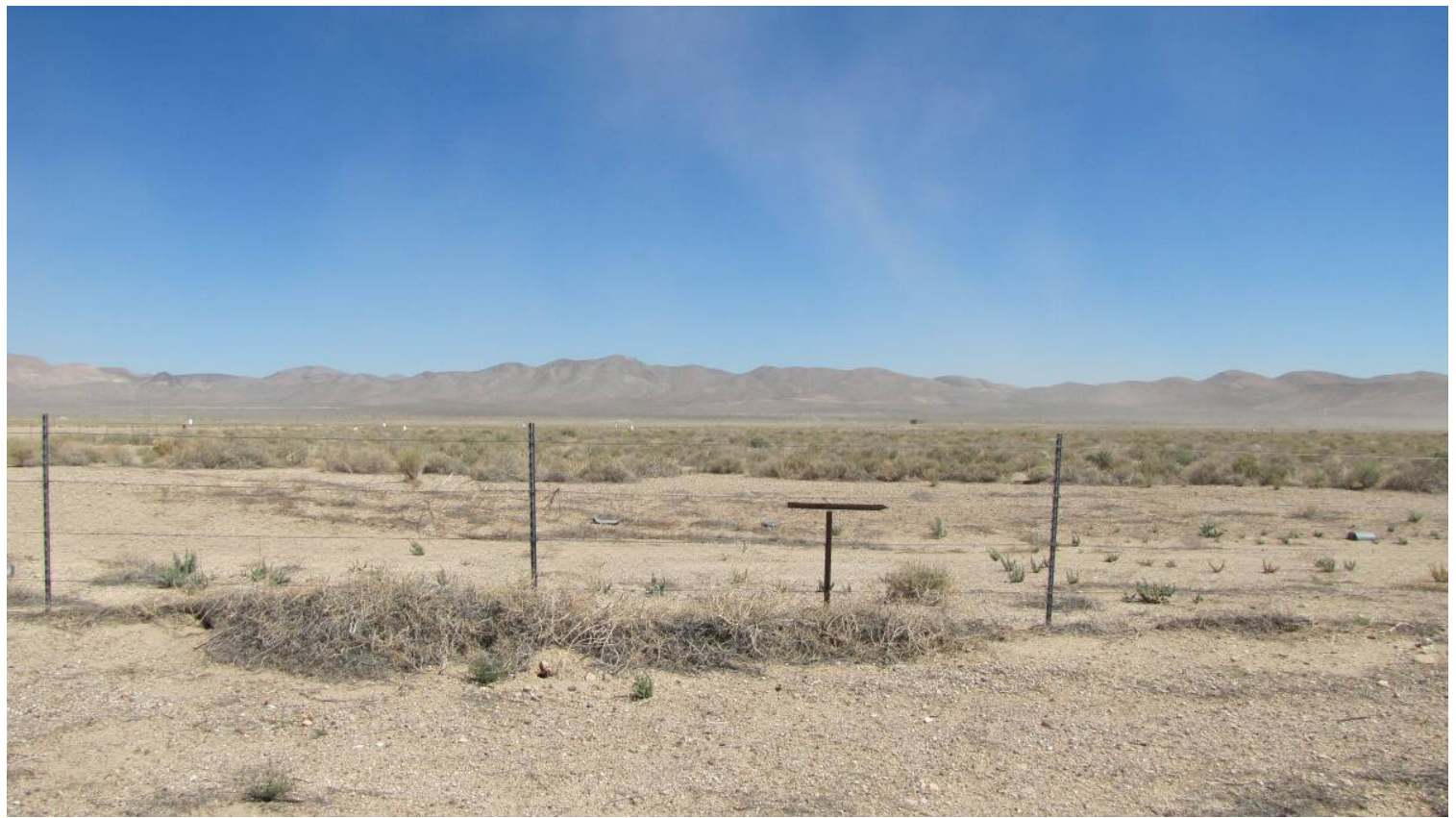

Photograph 86: CAU 110, Outside Facing East, 09/17/2013 


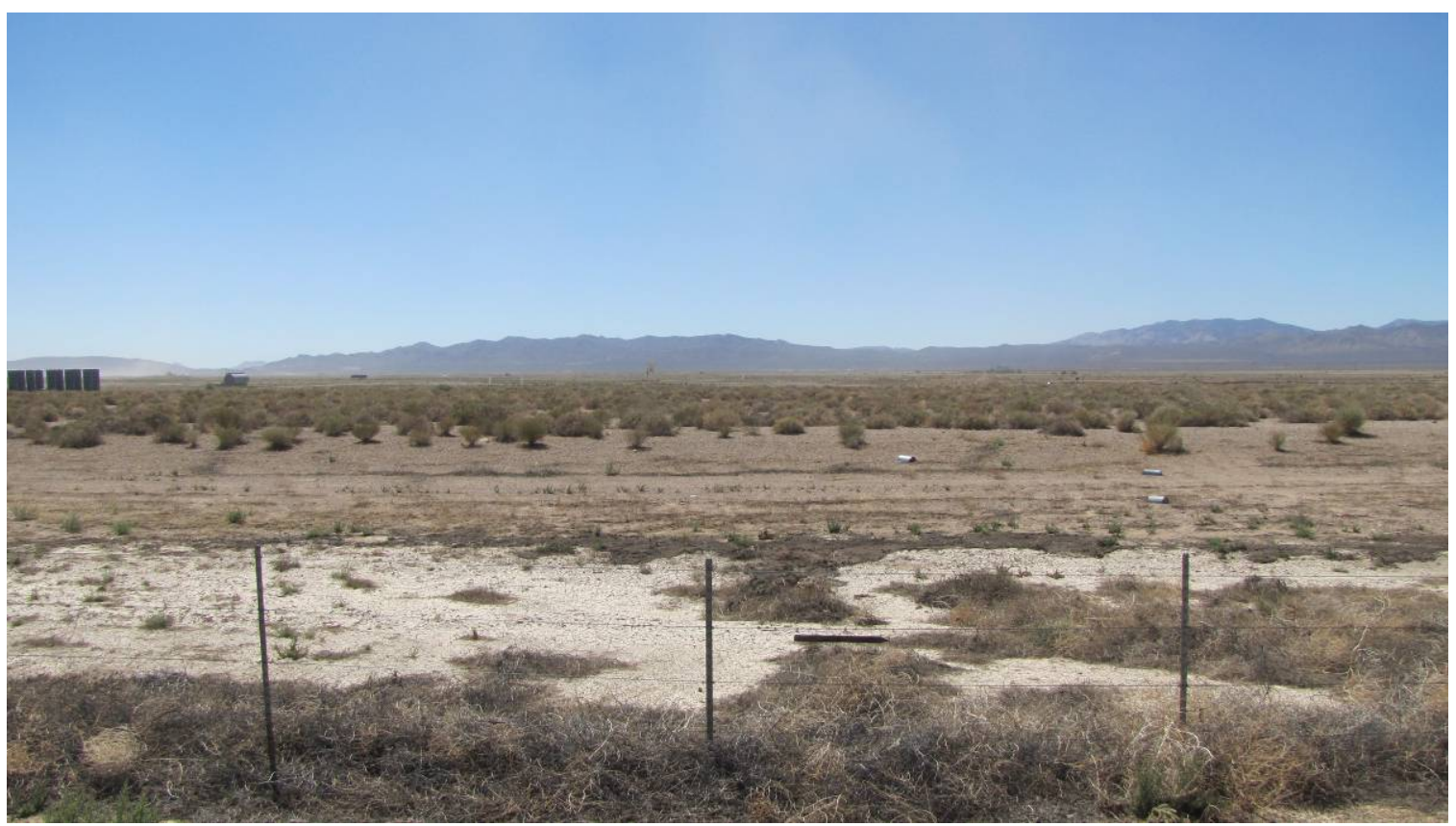

Photograph 87: CAU 110, Outside Facing South, 09/17/2013

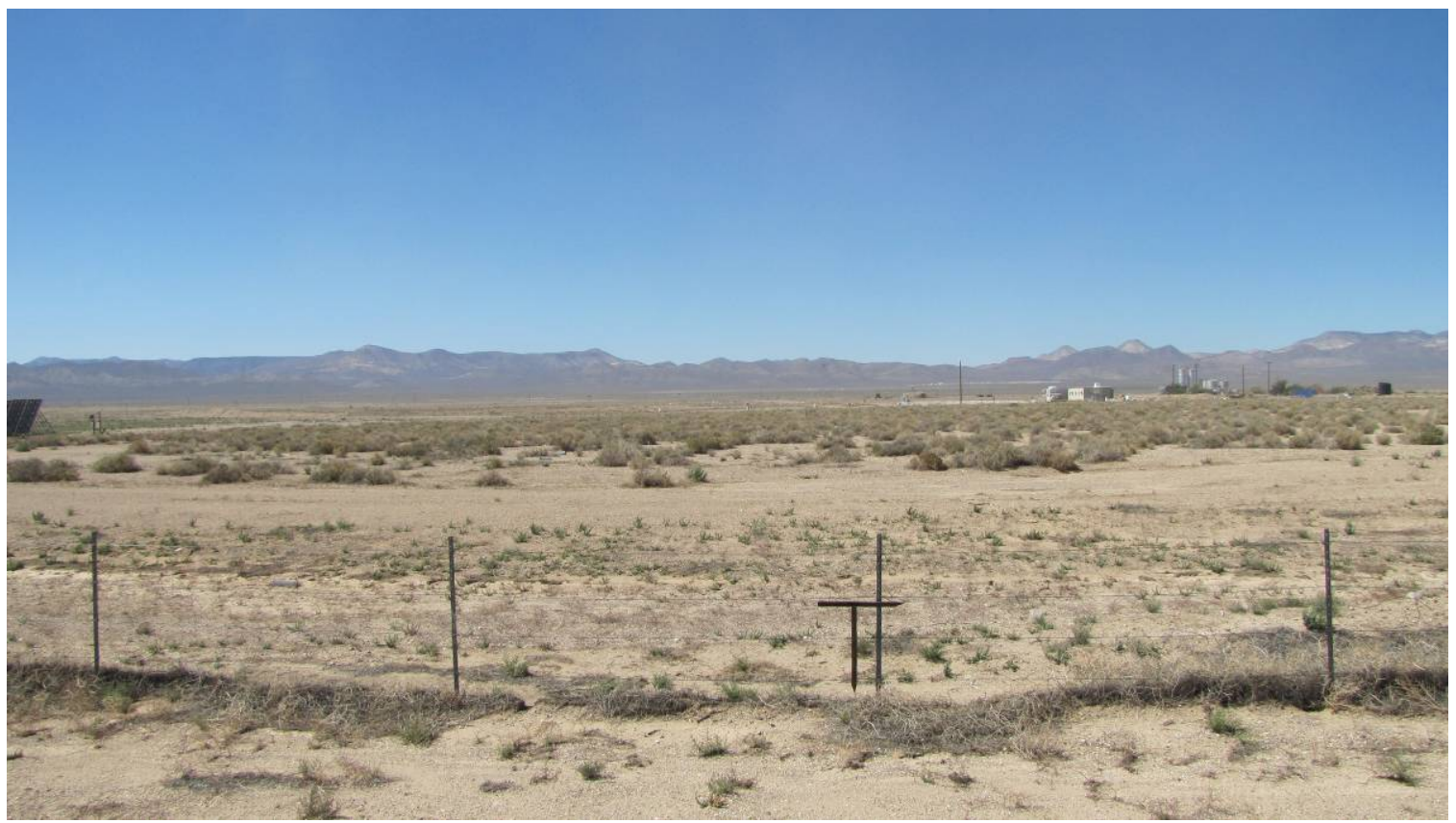

Photograph 88: CAU 110, Outside Facing West, 09/17/2013 


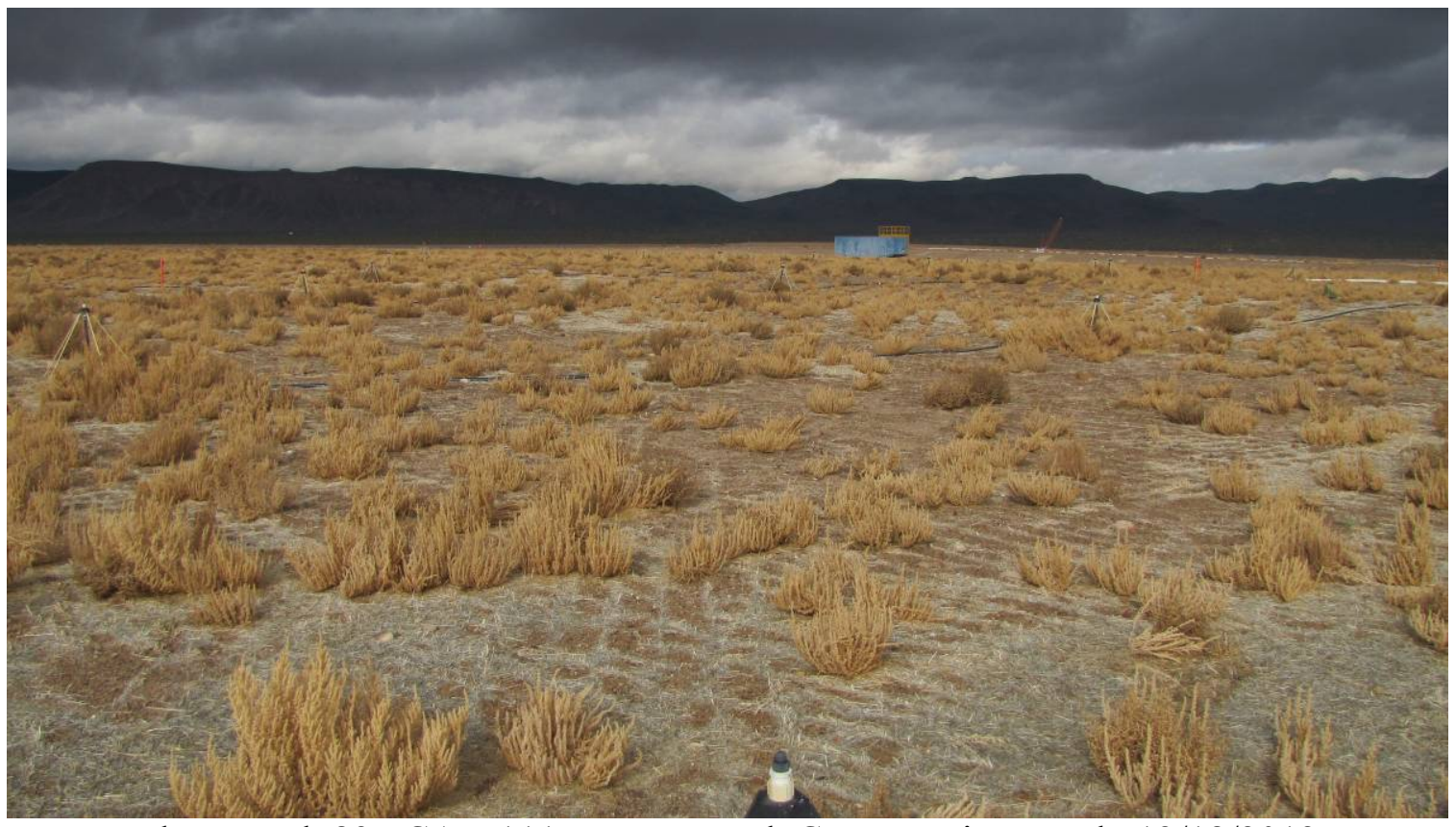

Photograph 89: CAU 111, Lower North Cover Facing North, 12/18/2012

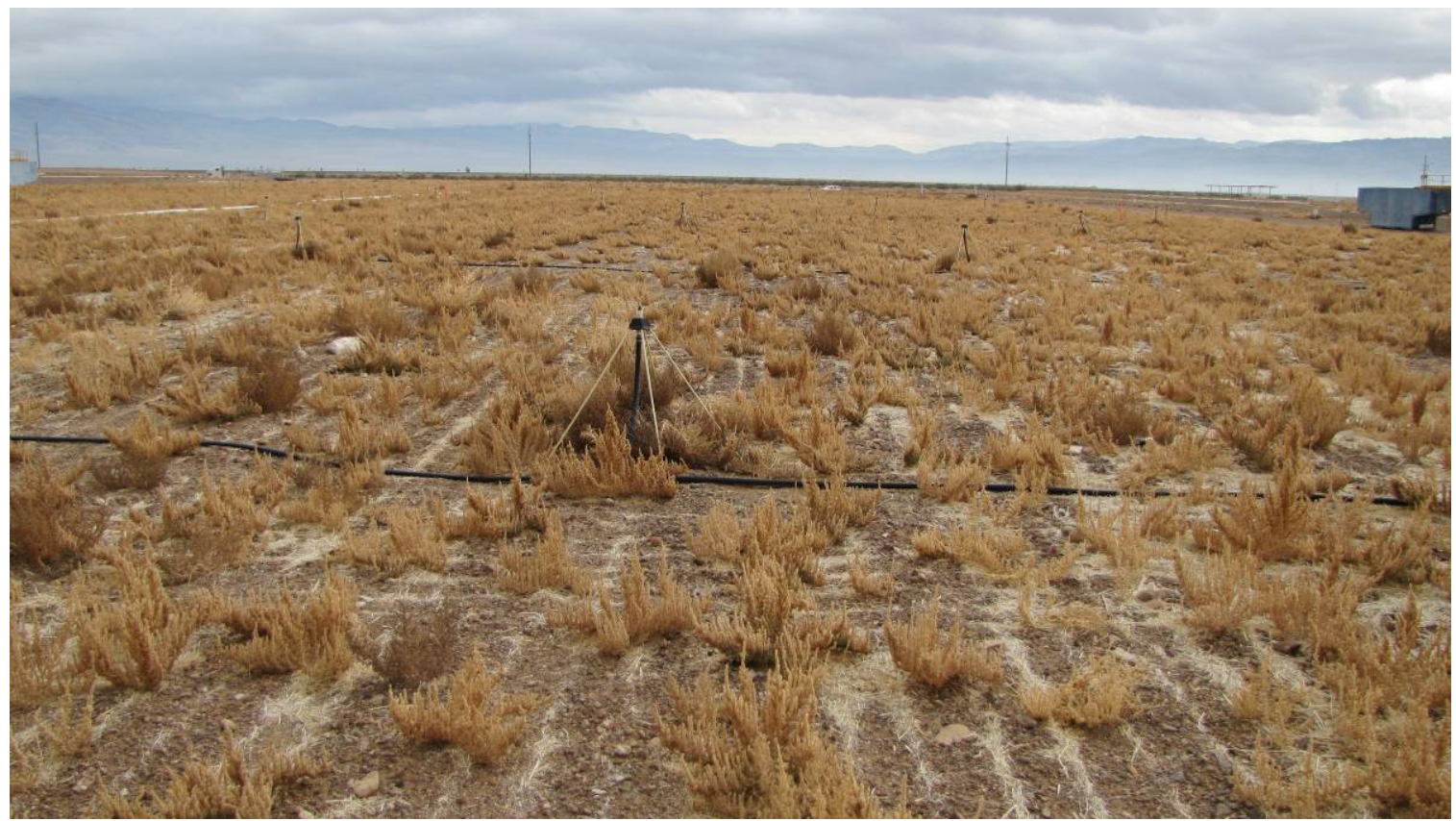

Photograph 90: CAU 111, Lower North Cover Facing East, 12/18/2012 


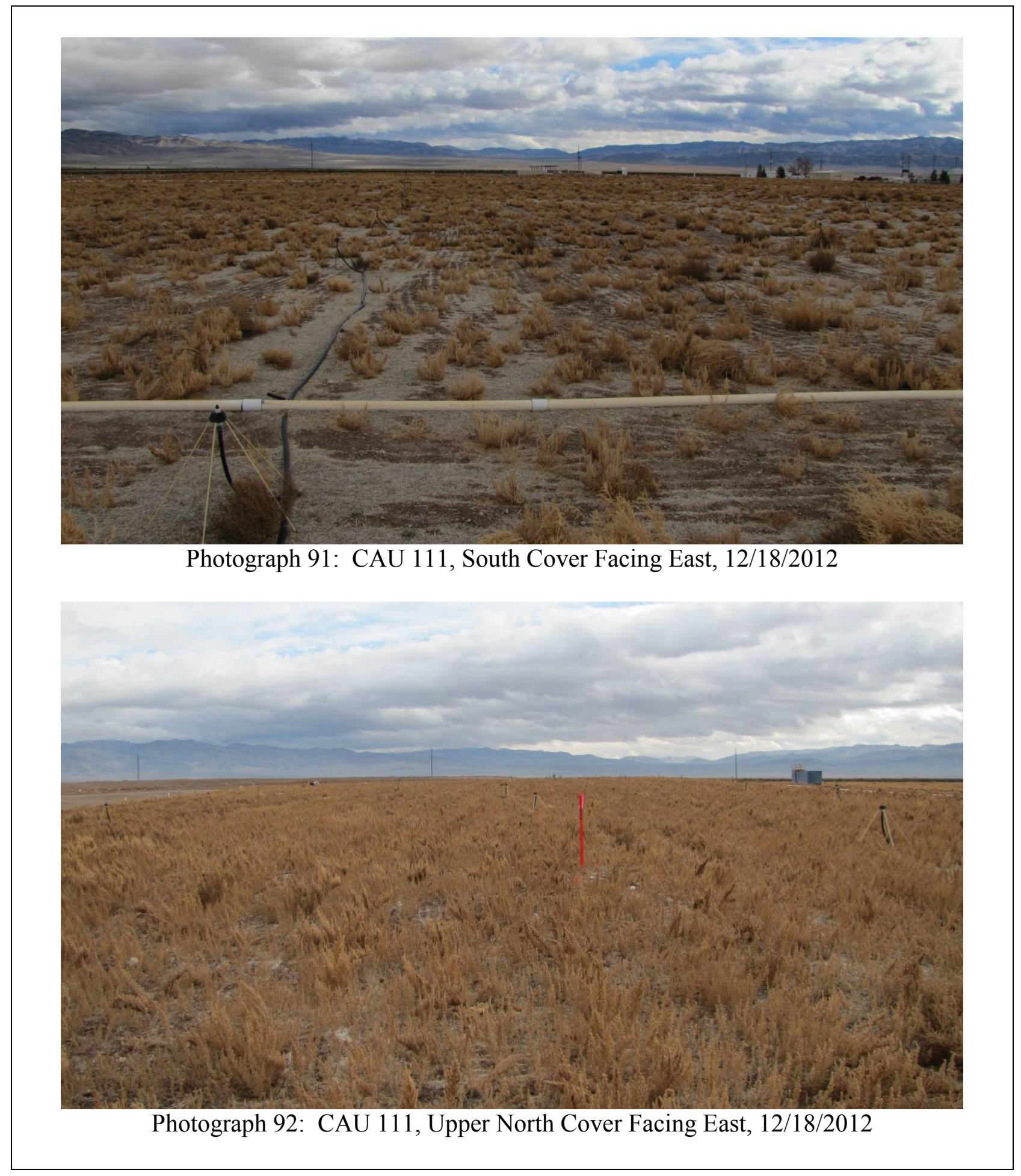


RCRA Post-Closure Report

Date: January 2014

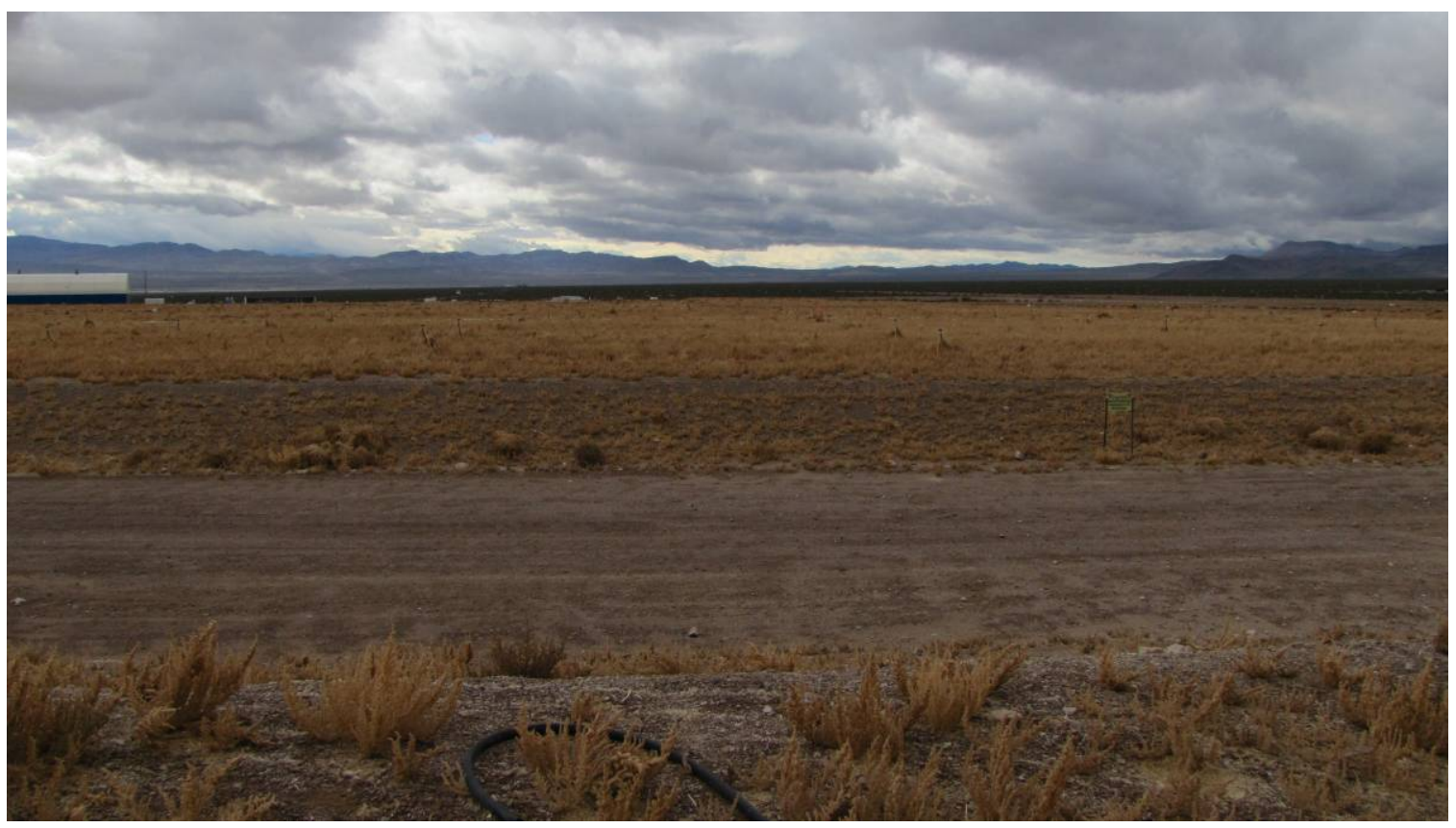

Photograph 93: CAU 111, Upper North Cover Facing South, 12/18/2012

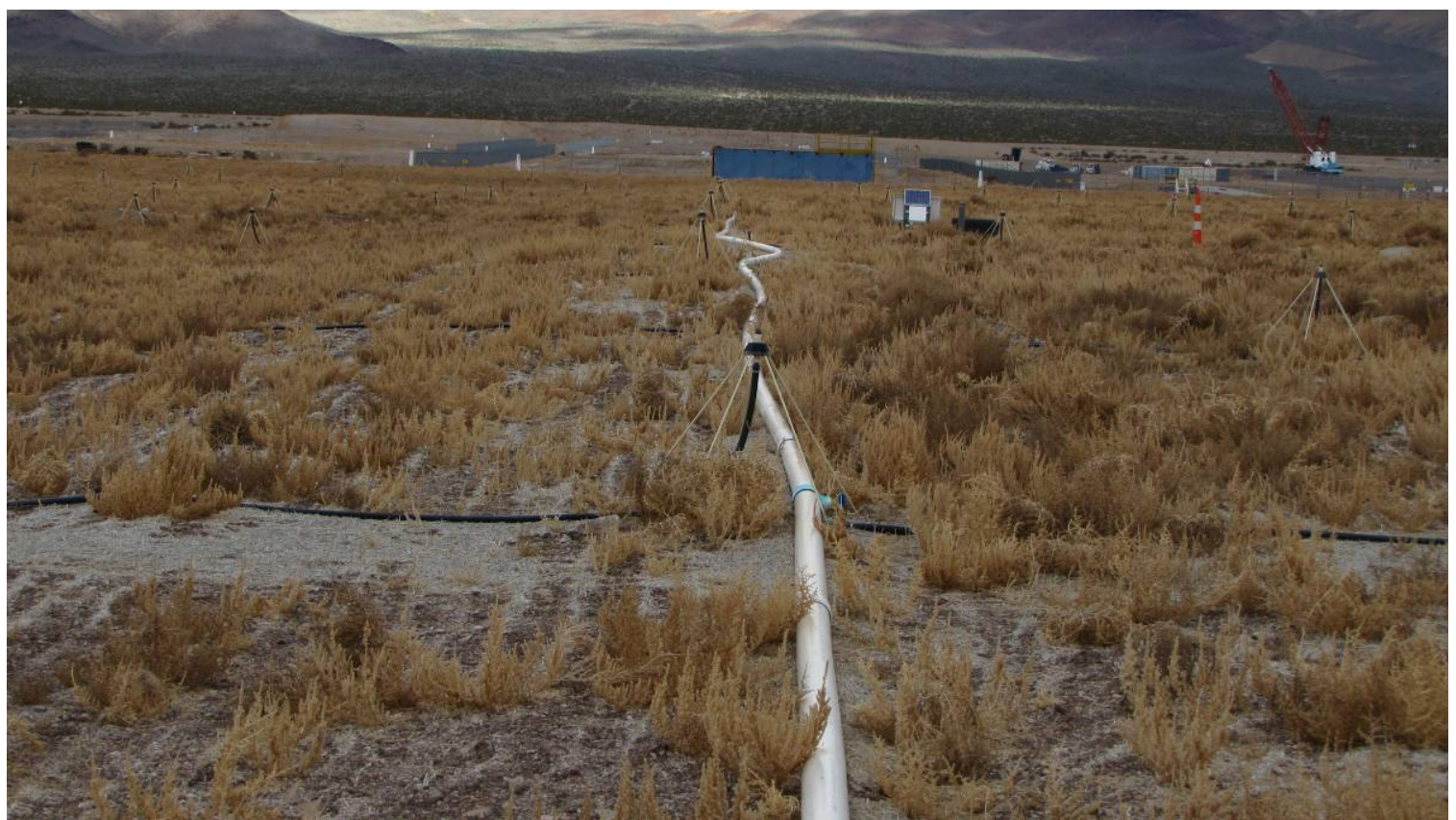

Photograph 94: CAU 111, West Cover Facing North, 12/18/2012 


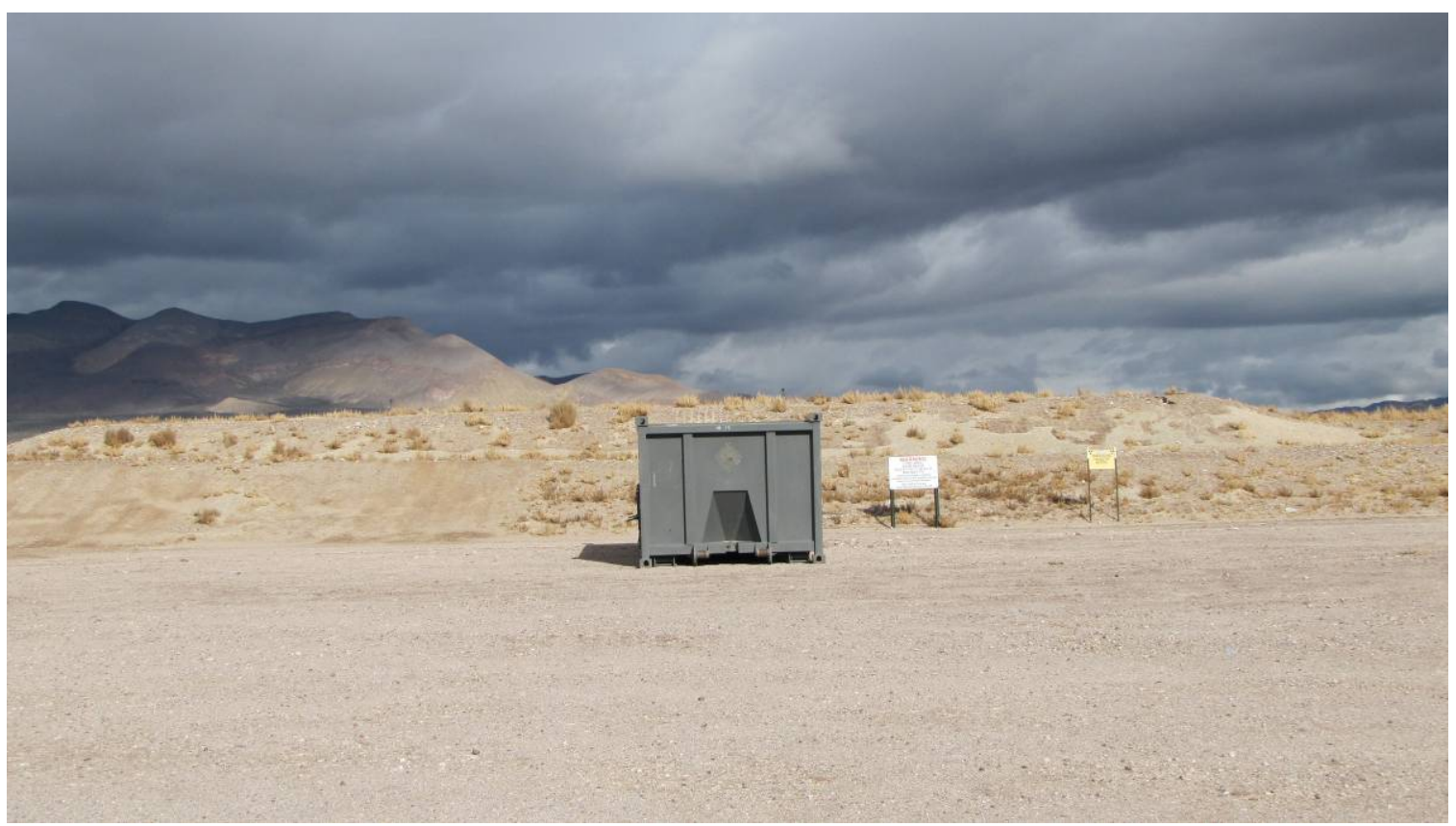

Photograph 95: CAU 111, South Cover Facing North, 12/18/2012

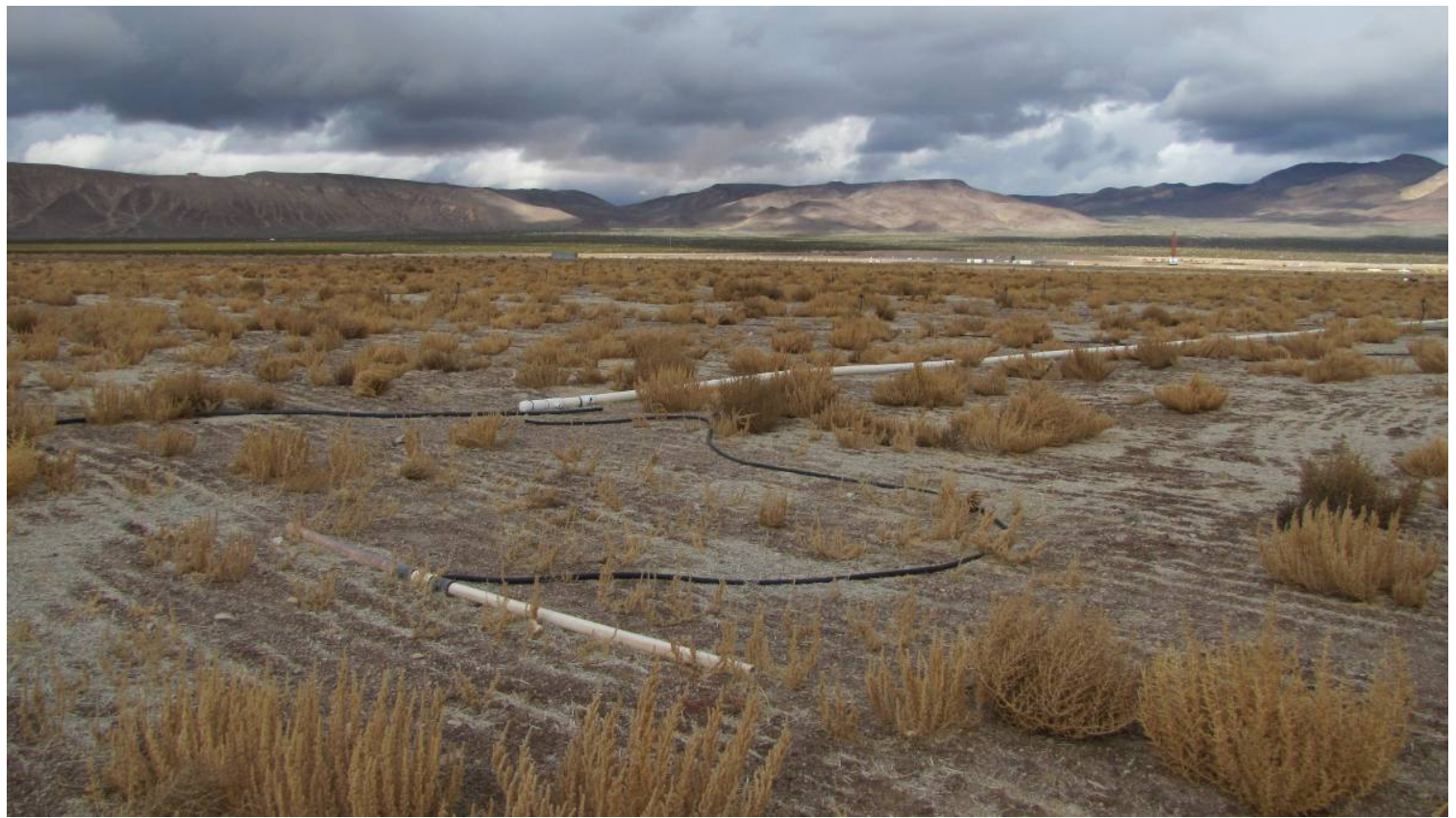

Photograph 96: CAU 111, South Cover Facing Northwest, 12/18/2012 
RCRA Post-Closure Report

Revision: 0

Date: January 2014

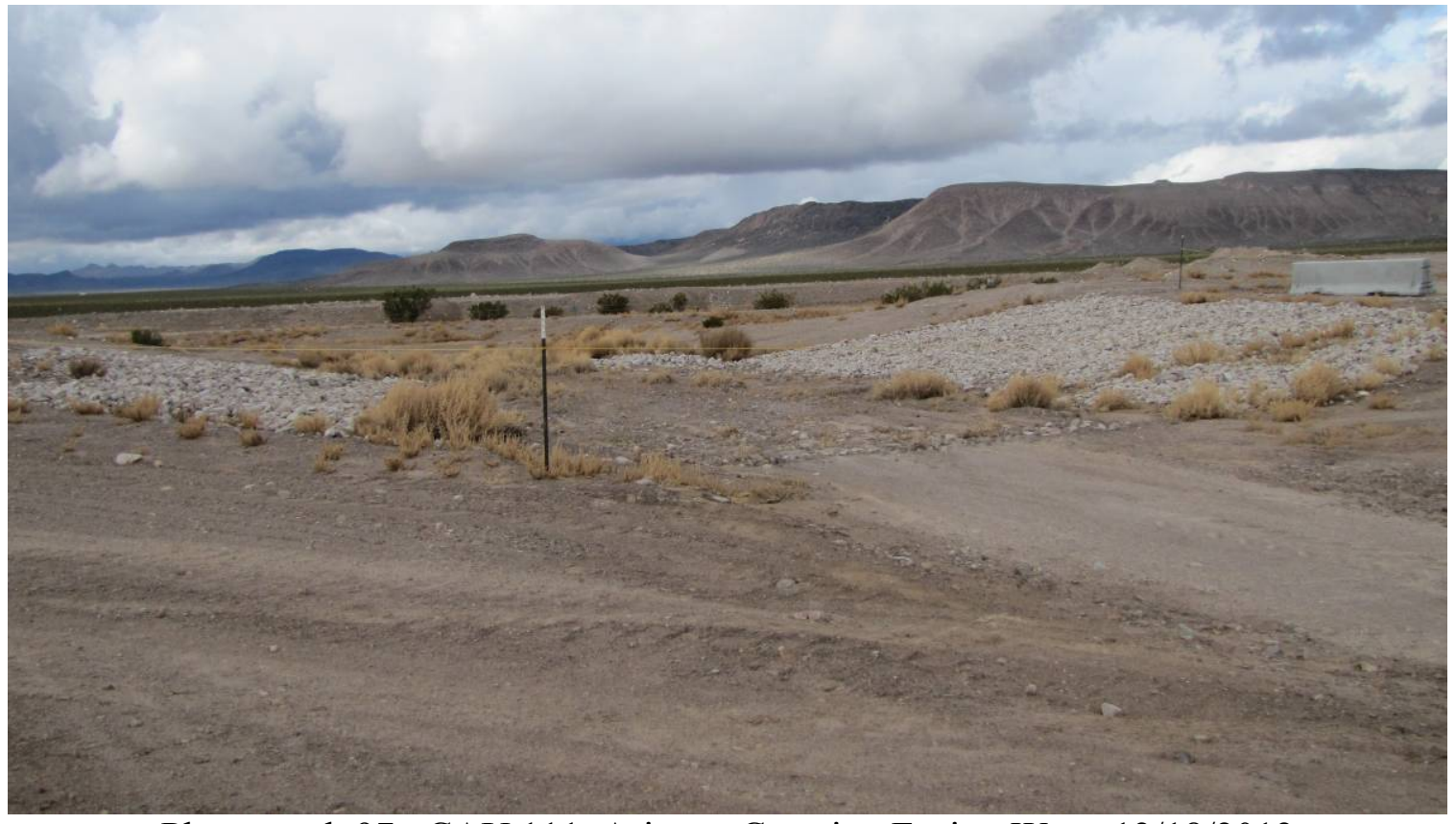

Photograph 97: CAU 111, Arizona Crossing Facing West, 12/18/2012 


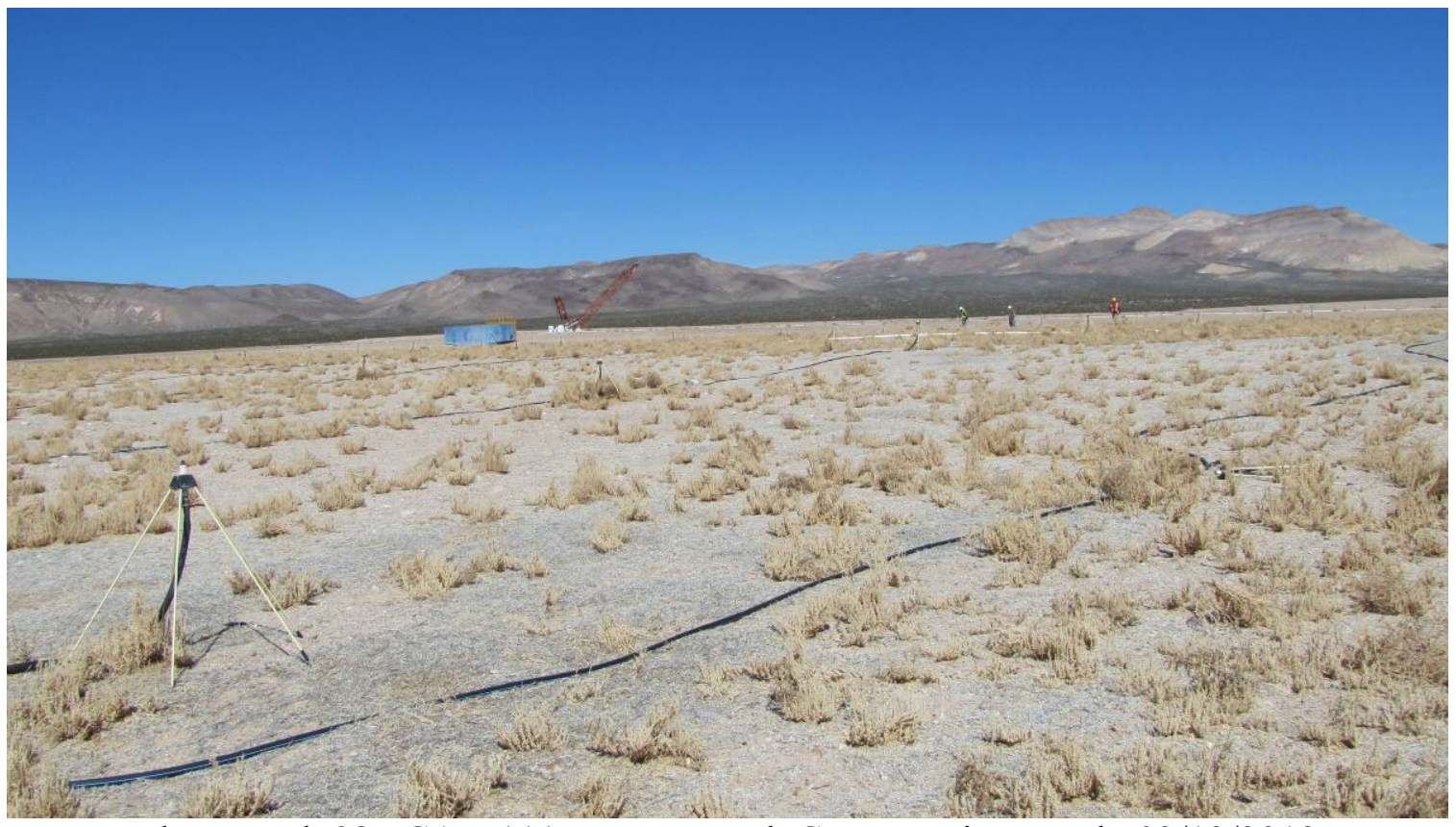

Photograph 98: CAU 111, Lower North Cover Facing North, 03/12/2013

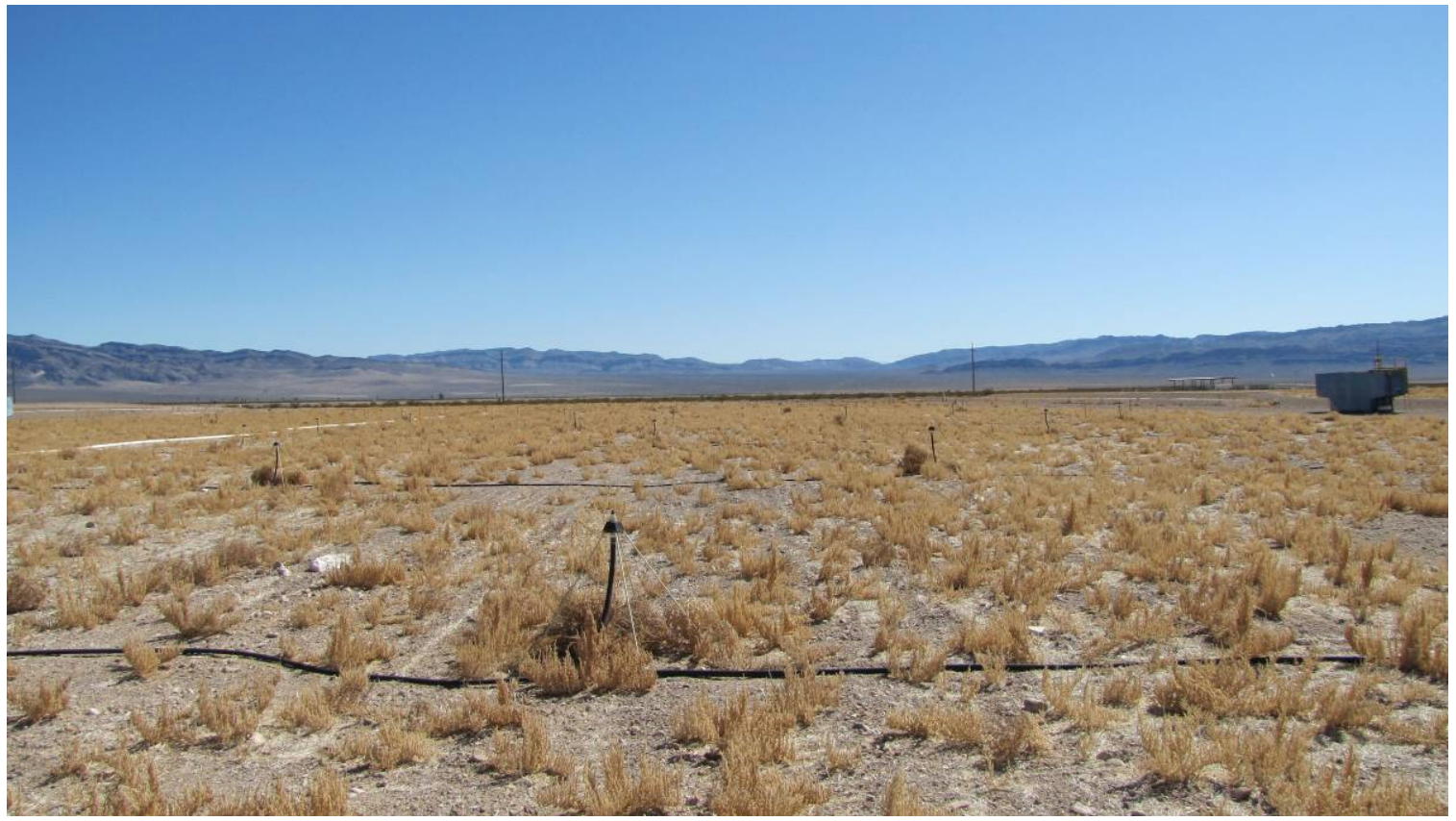

Photograph 99: CAU 111, Lower North Cover Facing East, 03/12/2013 


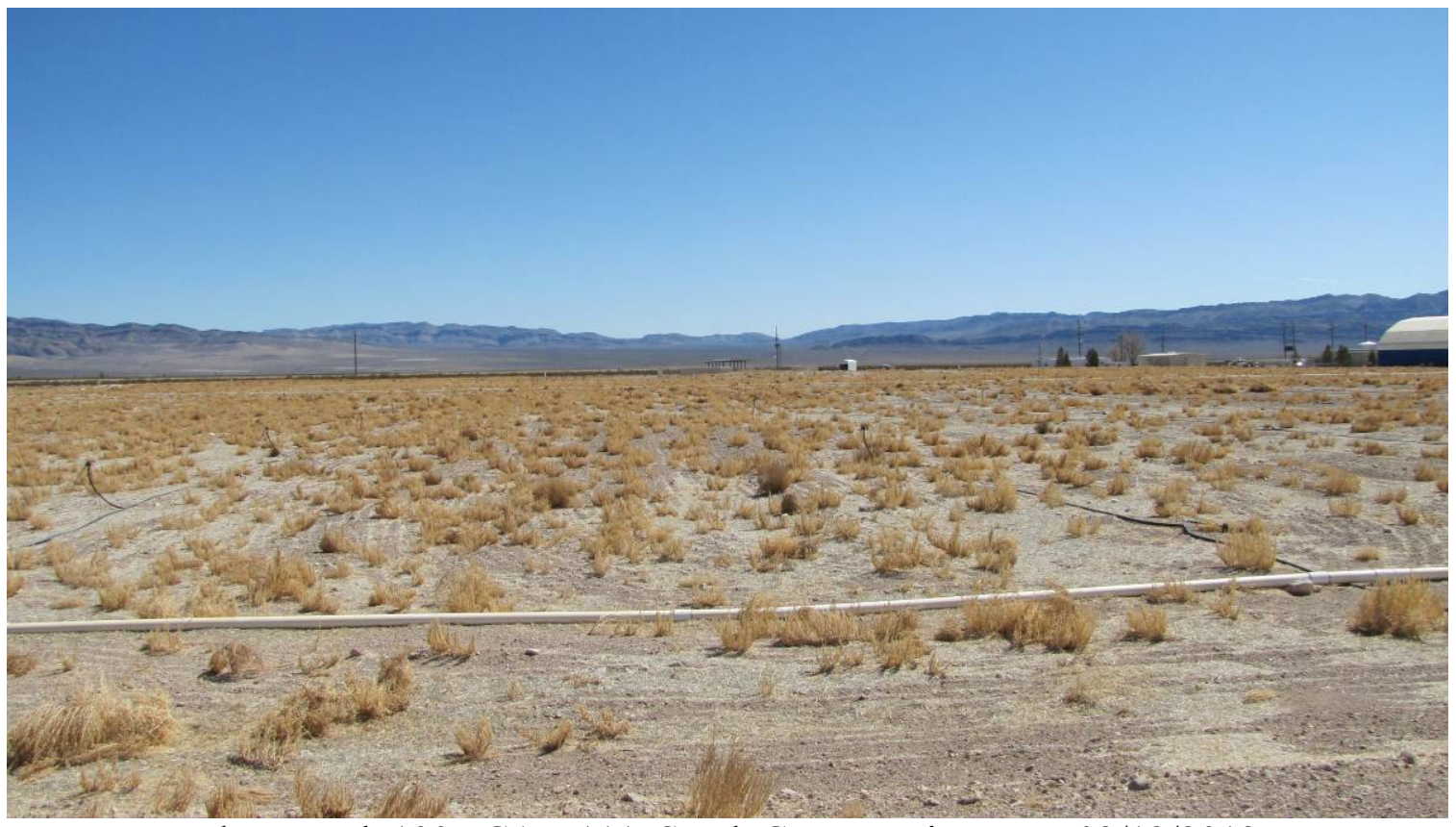

Photograph 100: CAU 111, South Cover Facing East, 03/12/2013

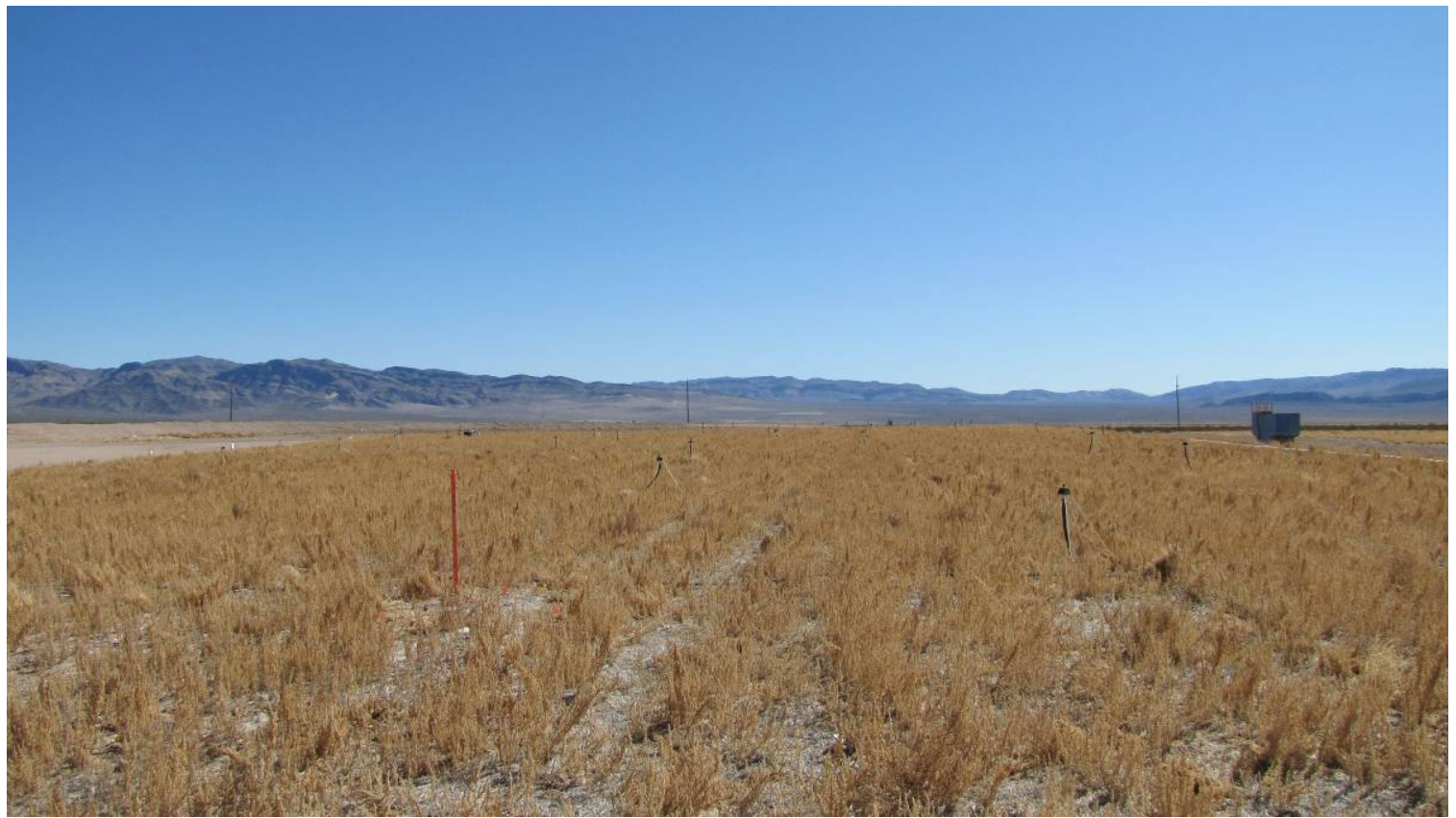

Photograph 101: CAU 111, Upper North Cover Facing East, 03/12/2013 
RCRA Post-Closure Report

Date: January 2014

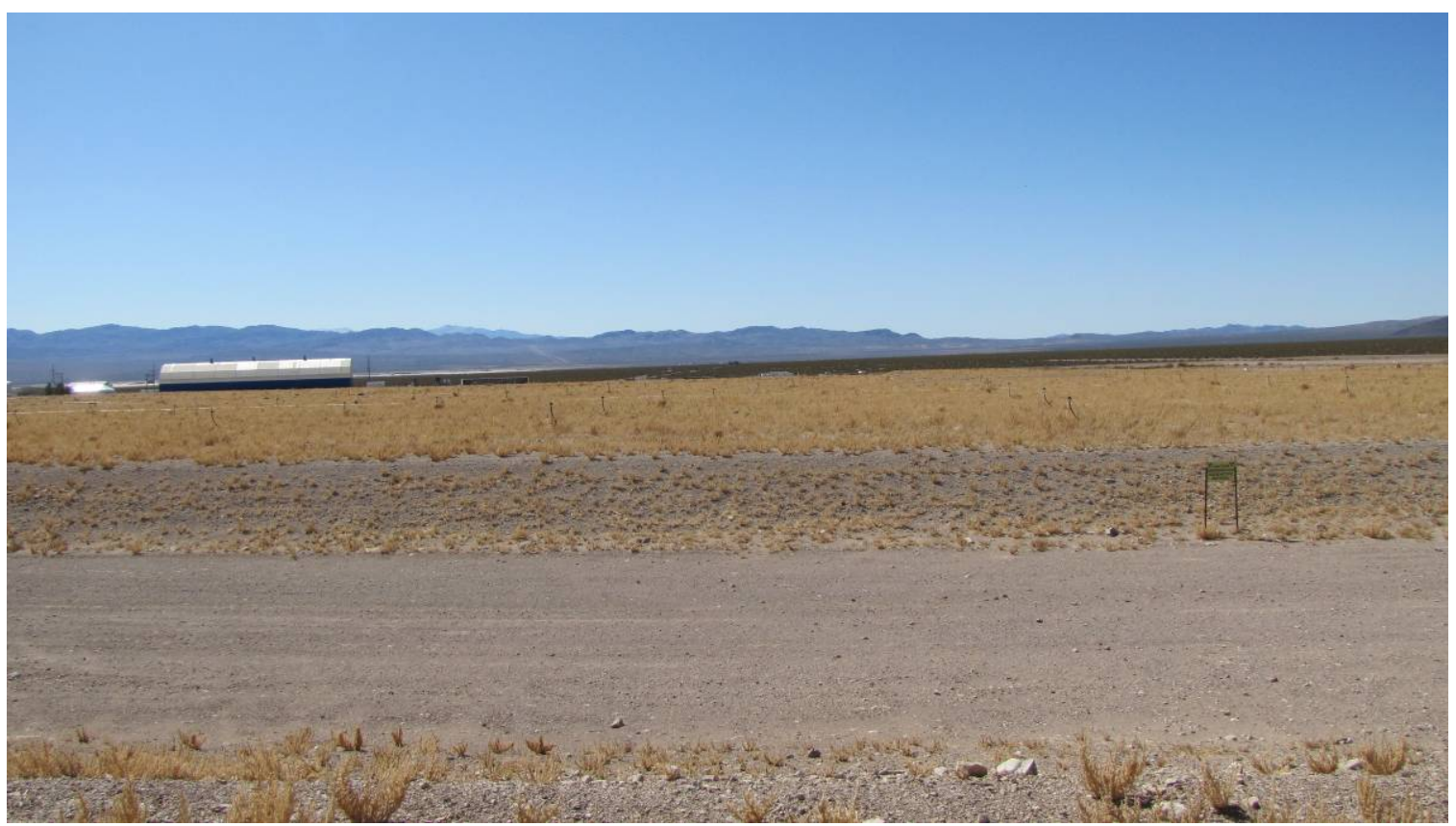

Photograph 102: CAU 111, Upper North Cover Facing South, 03/12/2013

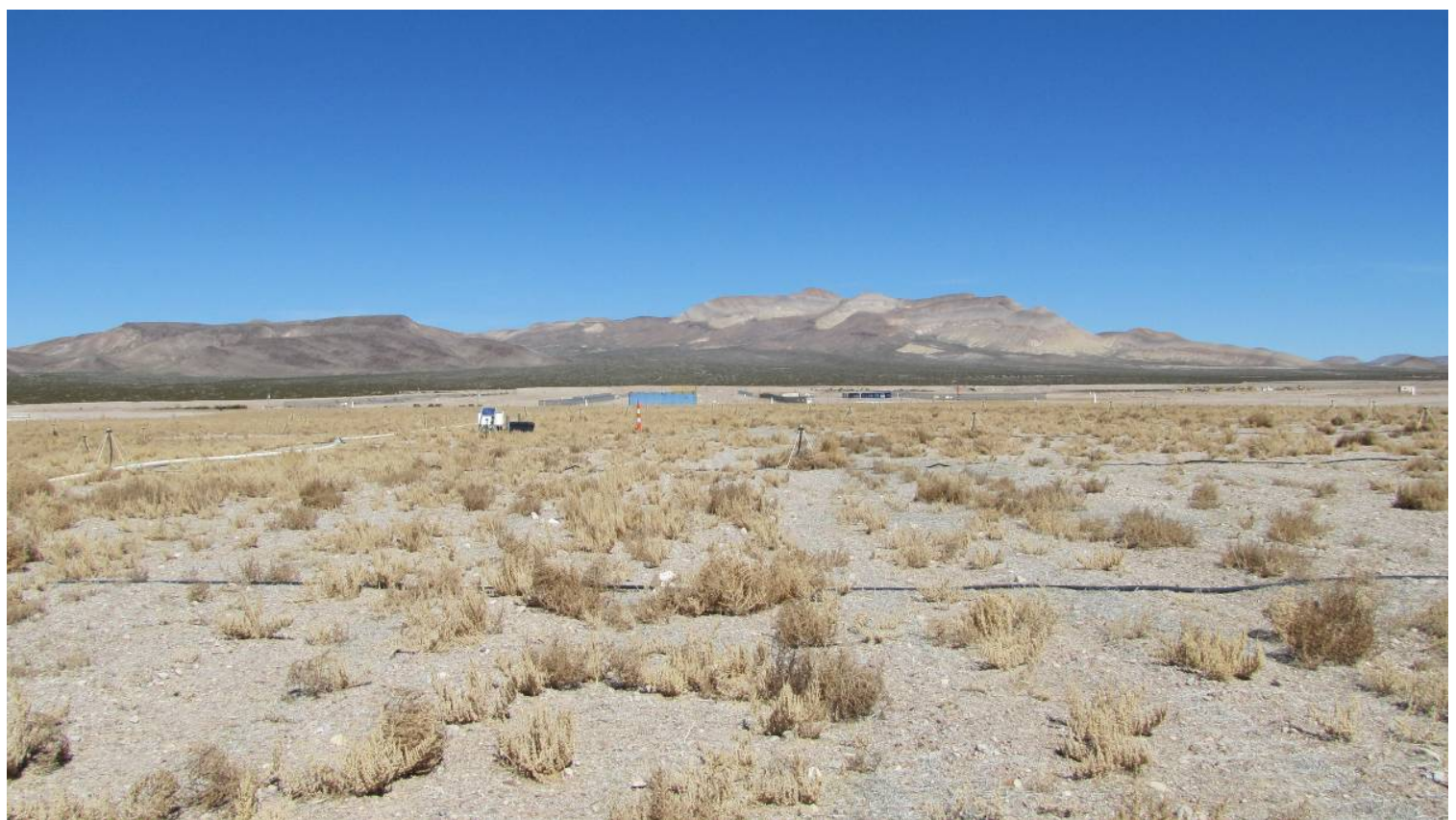

Photograph 103: CAU 111, West Cover Facing North, 03/12/2013 


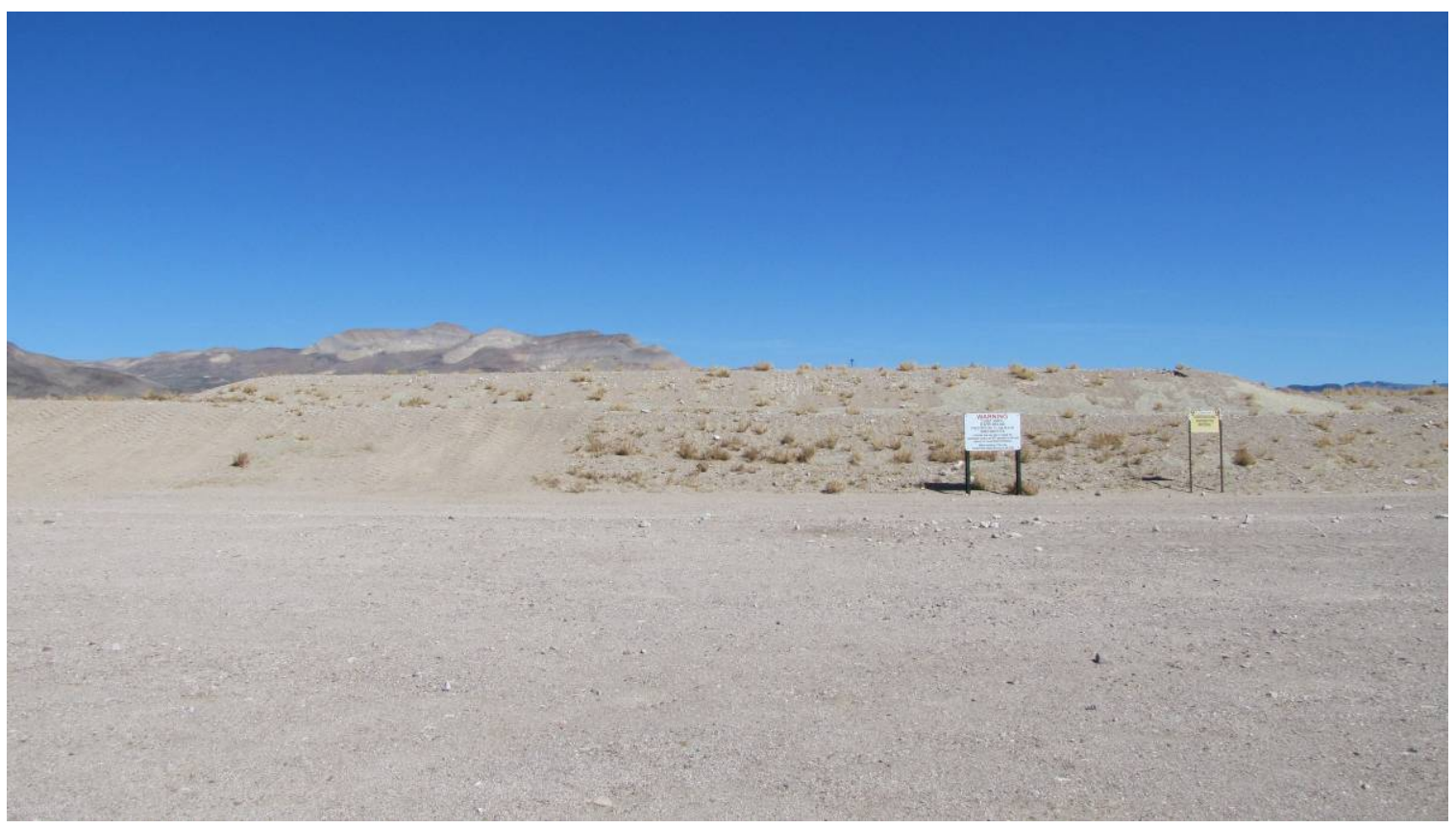

Photograph 104: CAU 111, South Cover Facing North, 03/12/2013

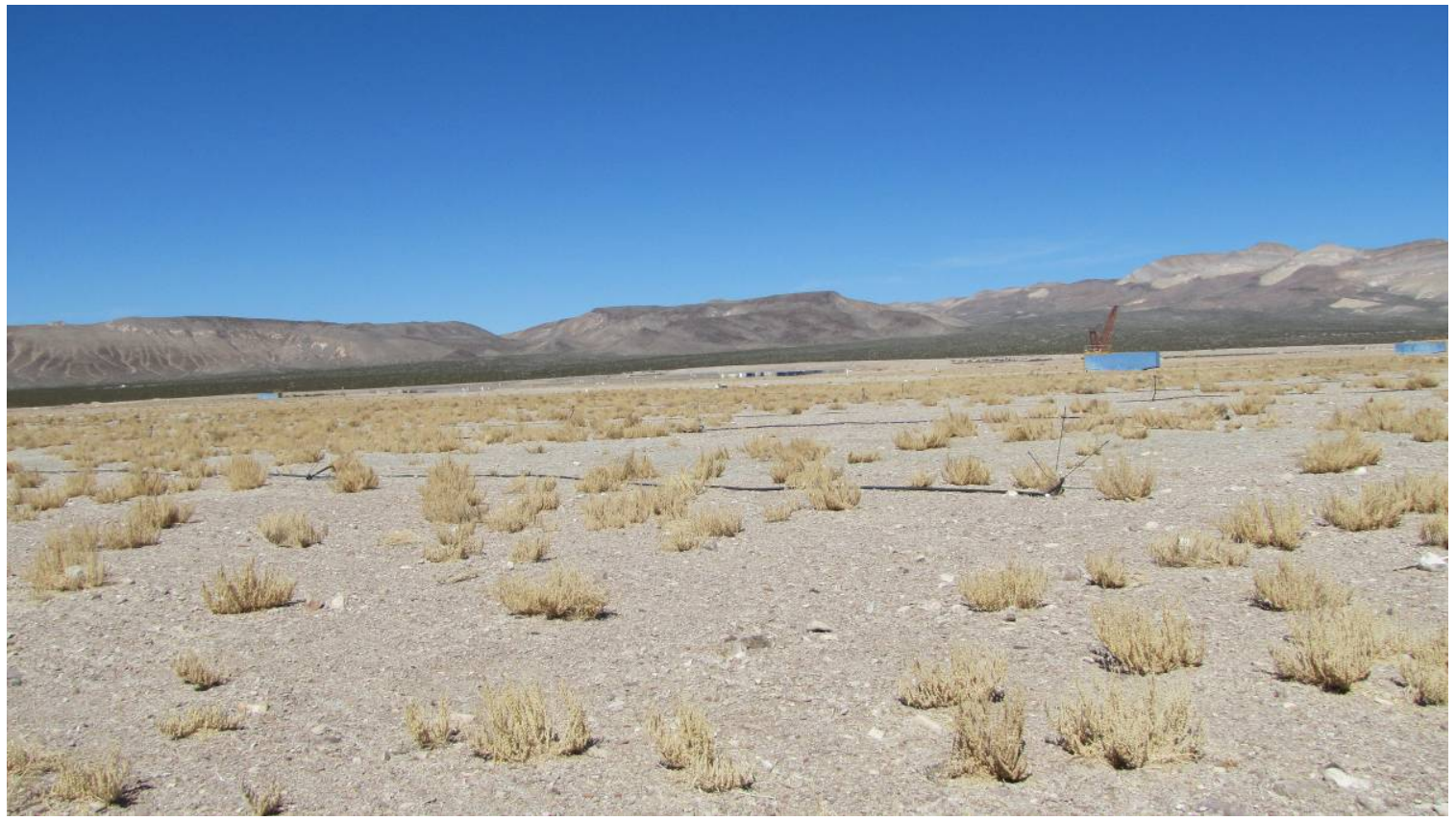

Photograph 105: CAU 111, South Cover Facing Northwest, 03/12/2013 
RCRA Post-Closure Report

Revision: 0

Date: January 2014

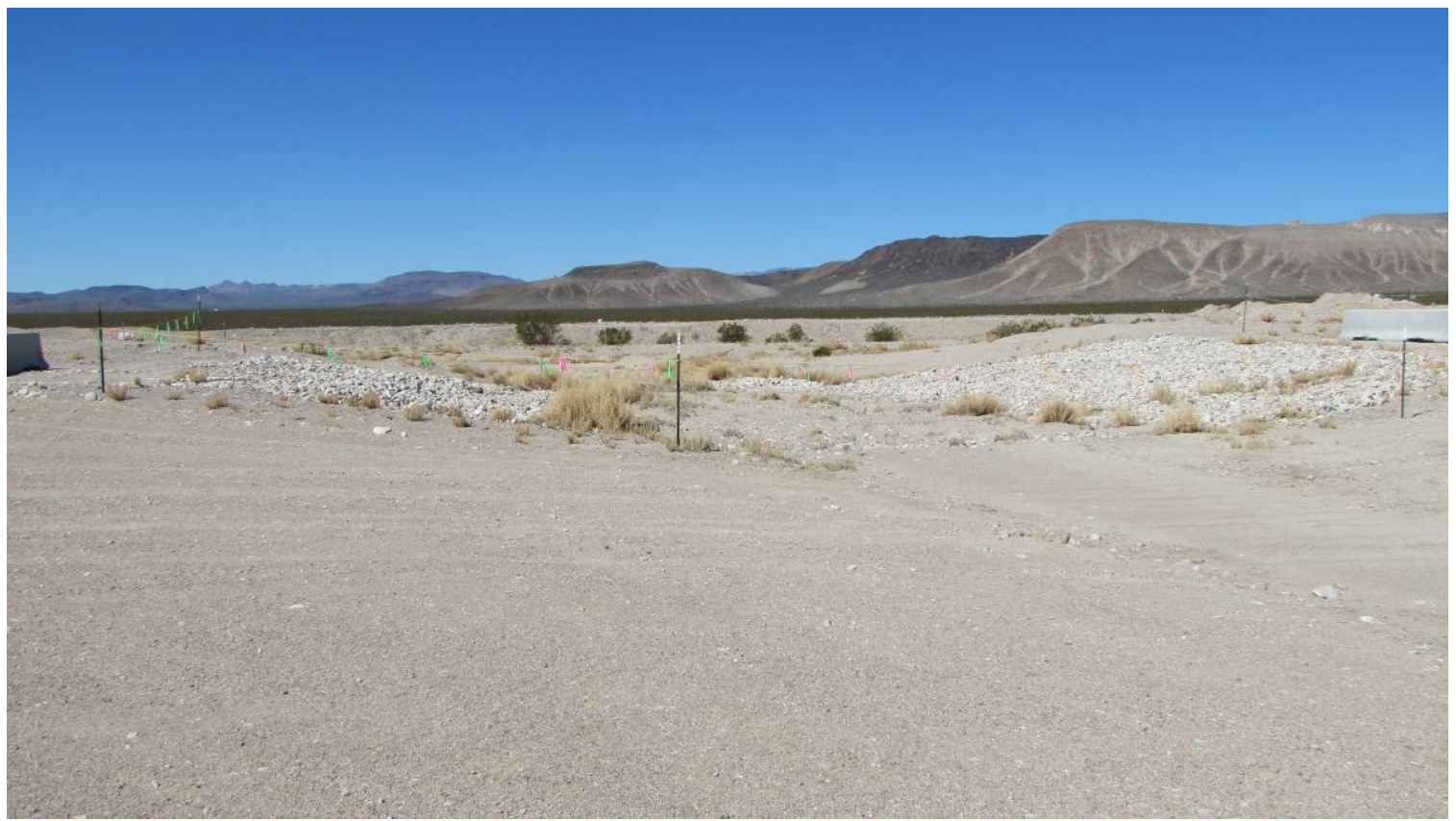

Photograph 106: CAU 111, Arizona Crossing Facing West, 03/12/2013 


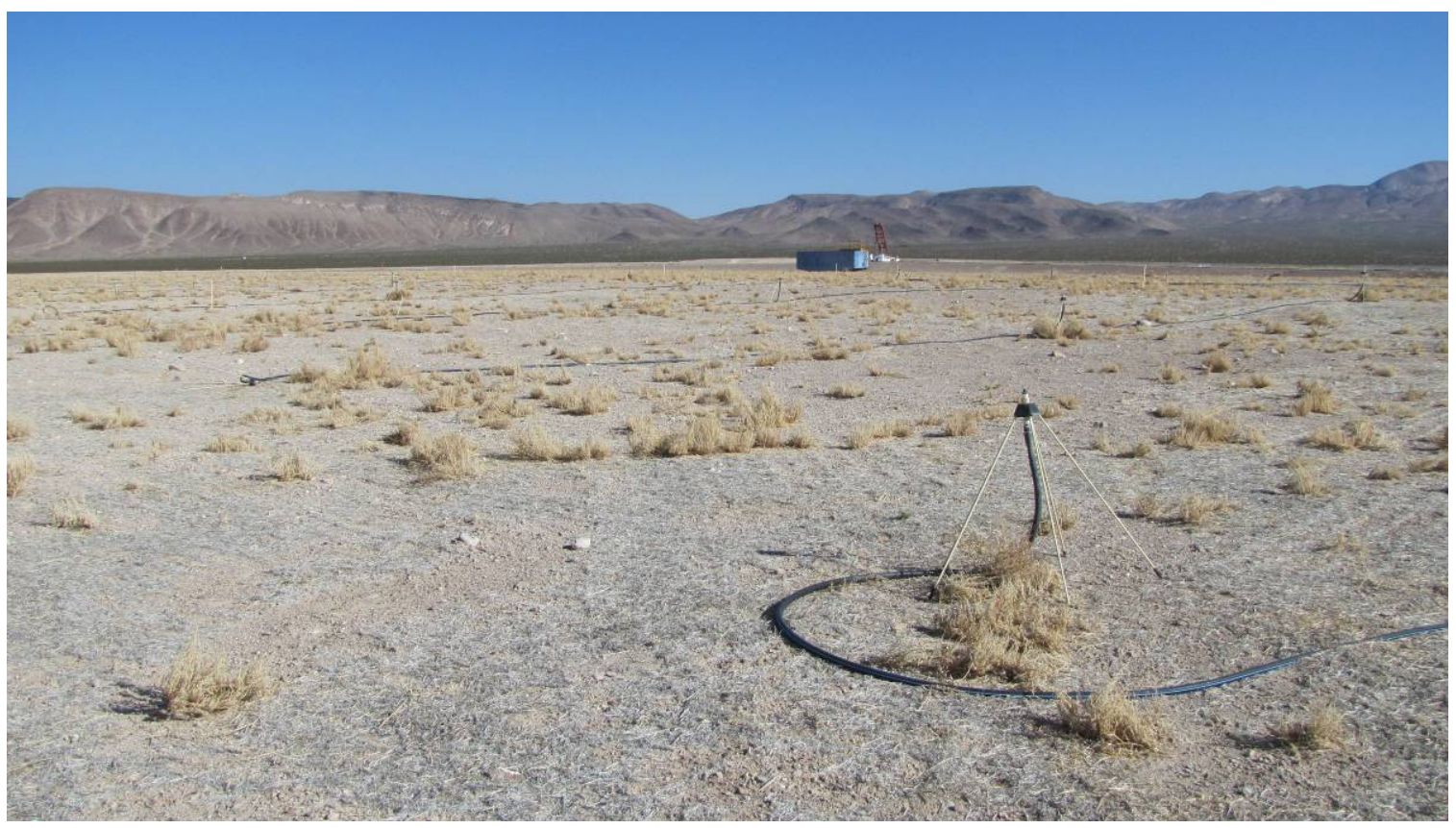

Photograph 107: CAU 111, Lower North Cover Facing North, 06/18/2013

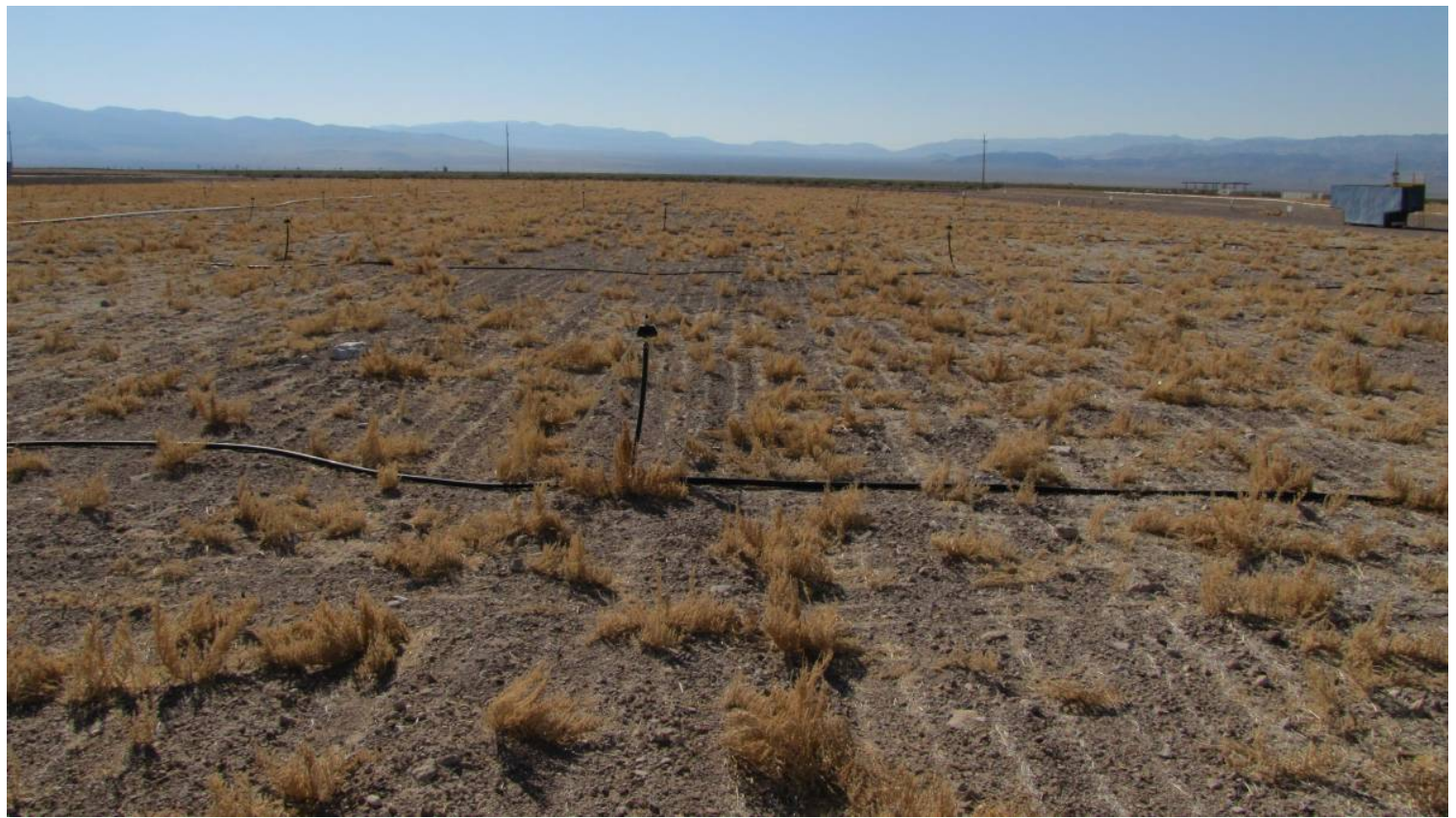

Photograph 108: CAU 111, Lower North Cover Facing East, 06/18/2013 


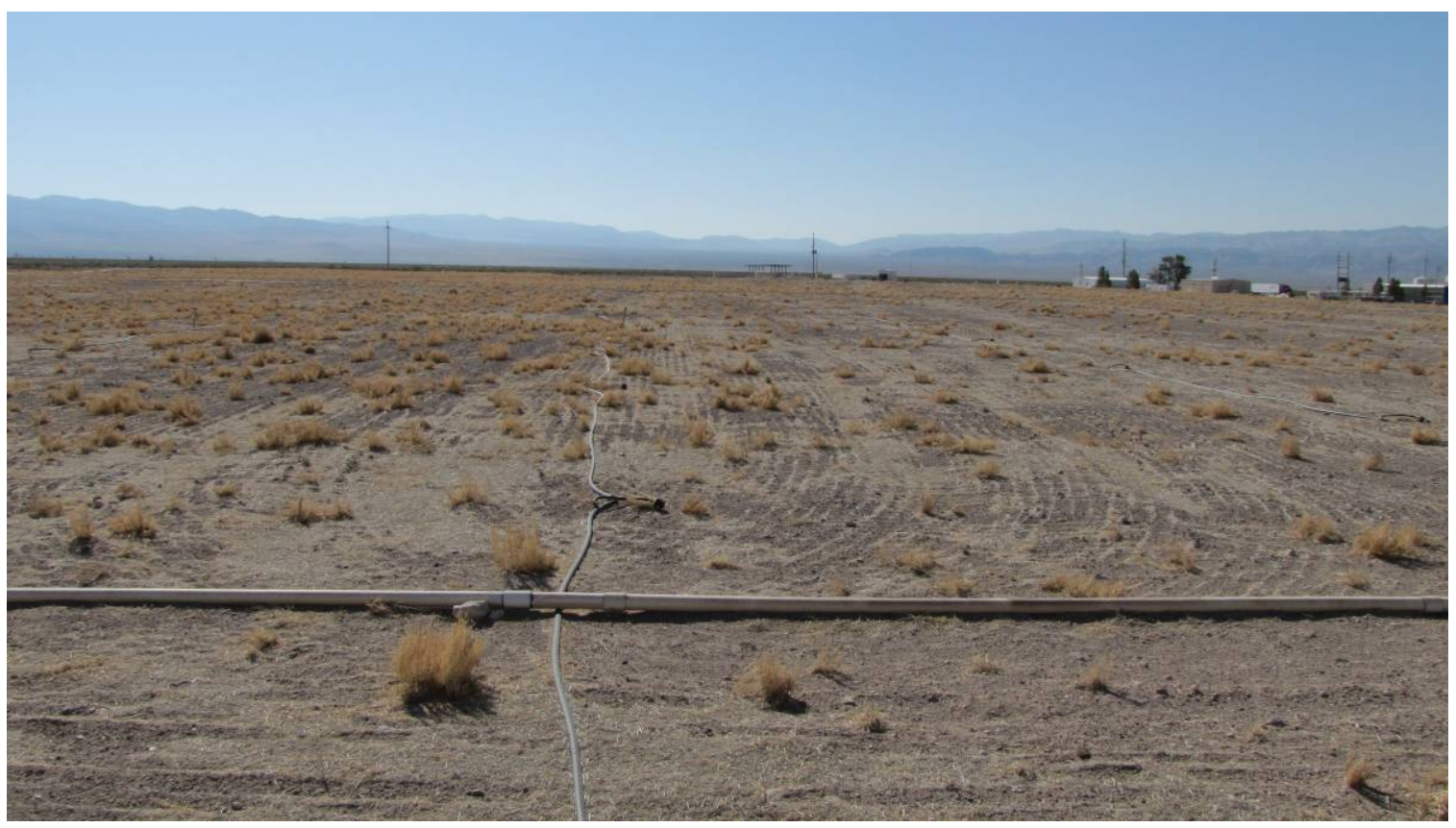

Photograph 109: CAU 111, South Cover Facing East, 06/18/2013

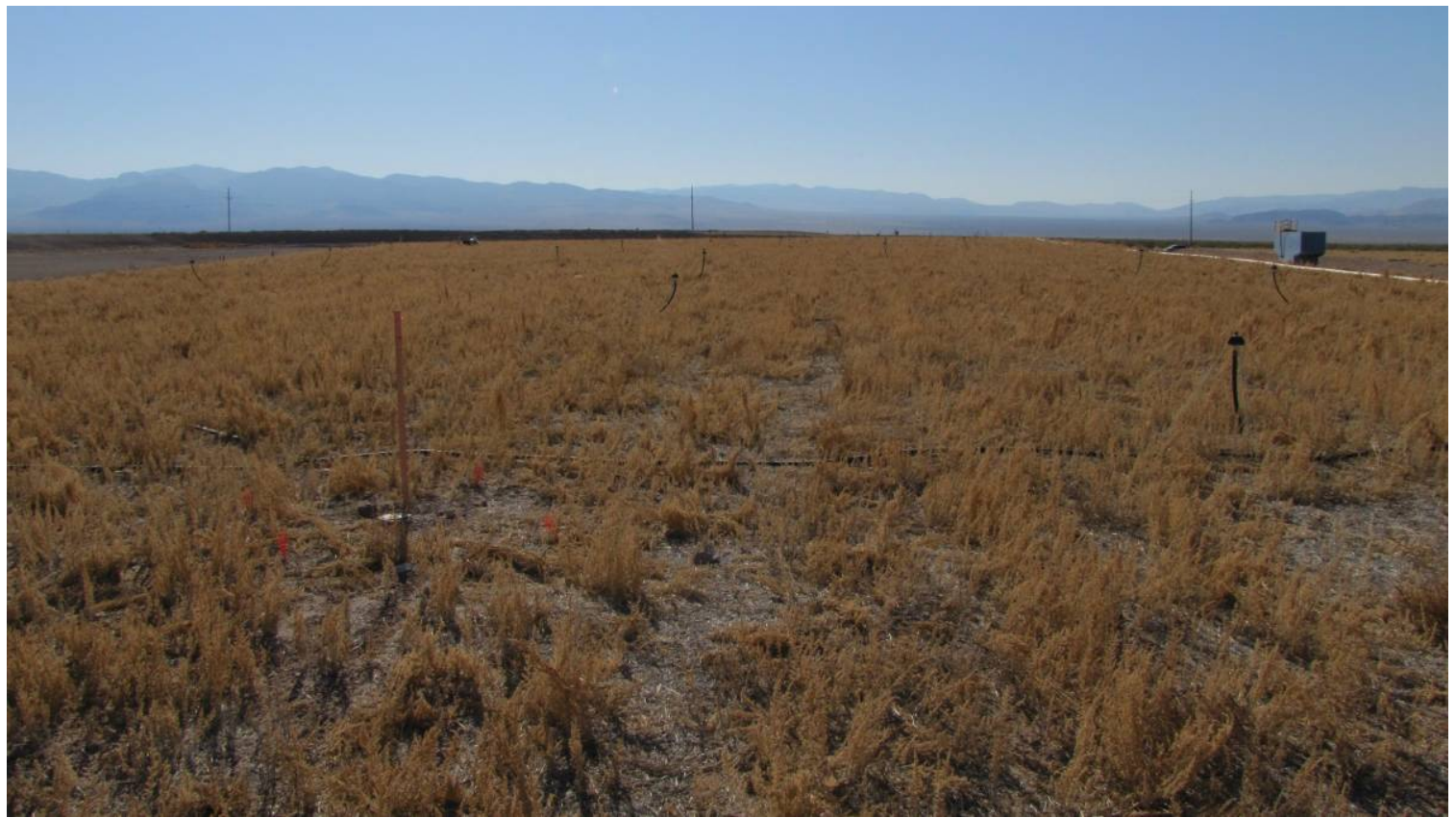

Photograph 110: CAU 111, Upper North Cover Facing East, 06/18/2013 
RCRA Post-Closure Report

Date: January 2014

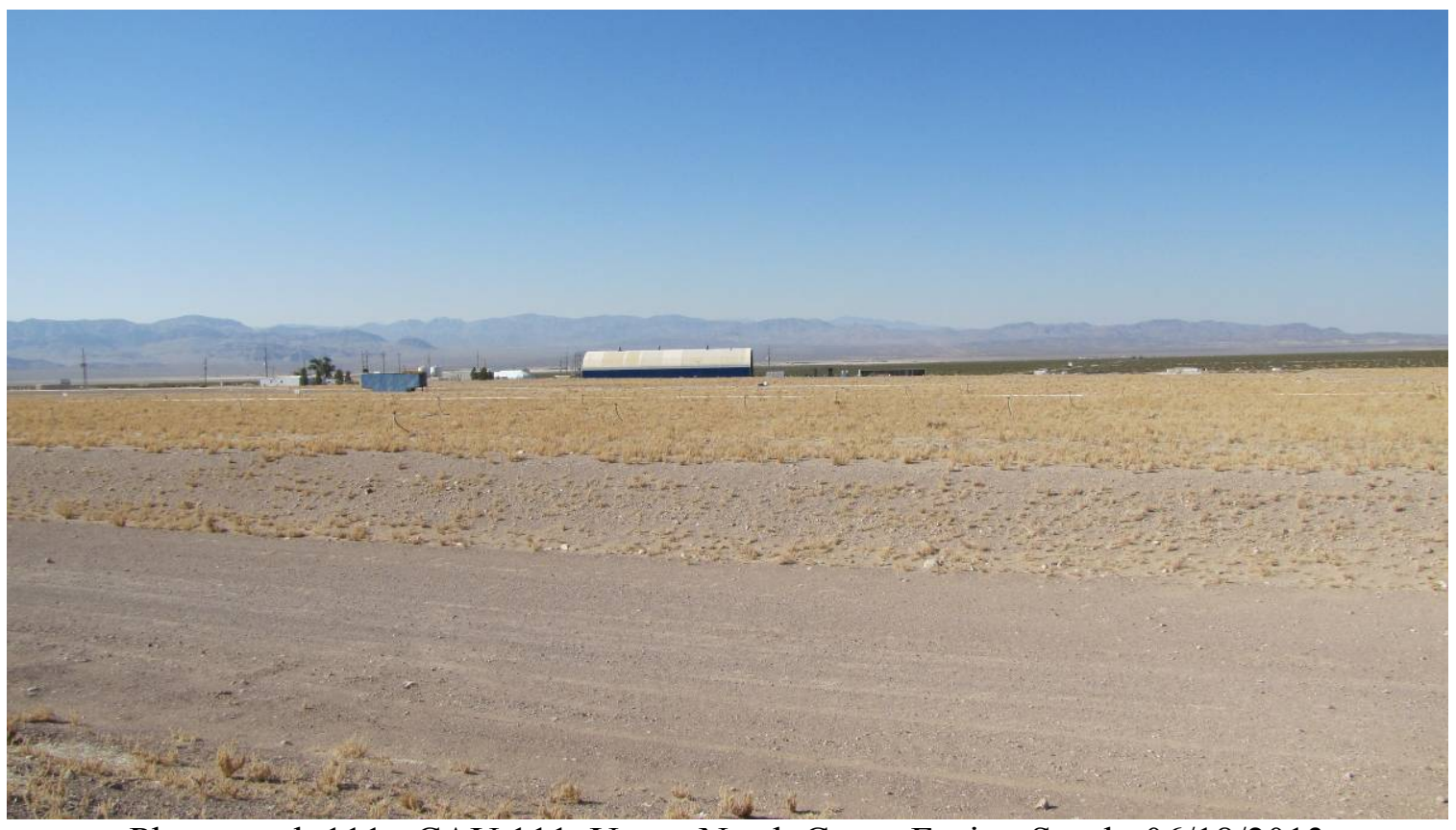

Photograph 111: CAU 111, Upper North Cover Facing South, 06/18/2013

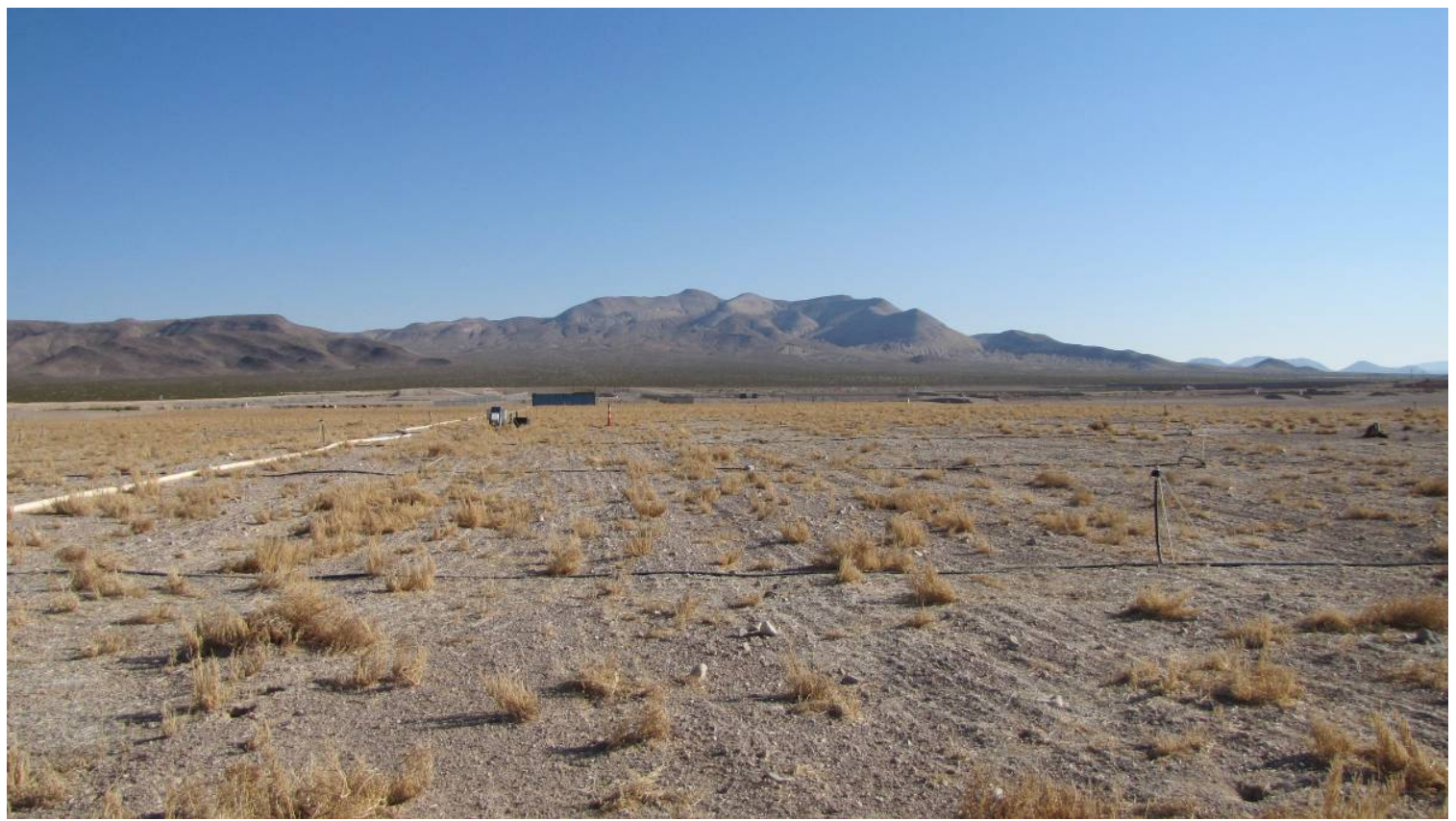

Photograph 112: CAU 111, West Cover Facing North, 06/18/2013 
RCRA Post-Closure Report

Date: January 2014

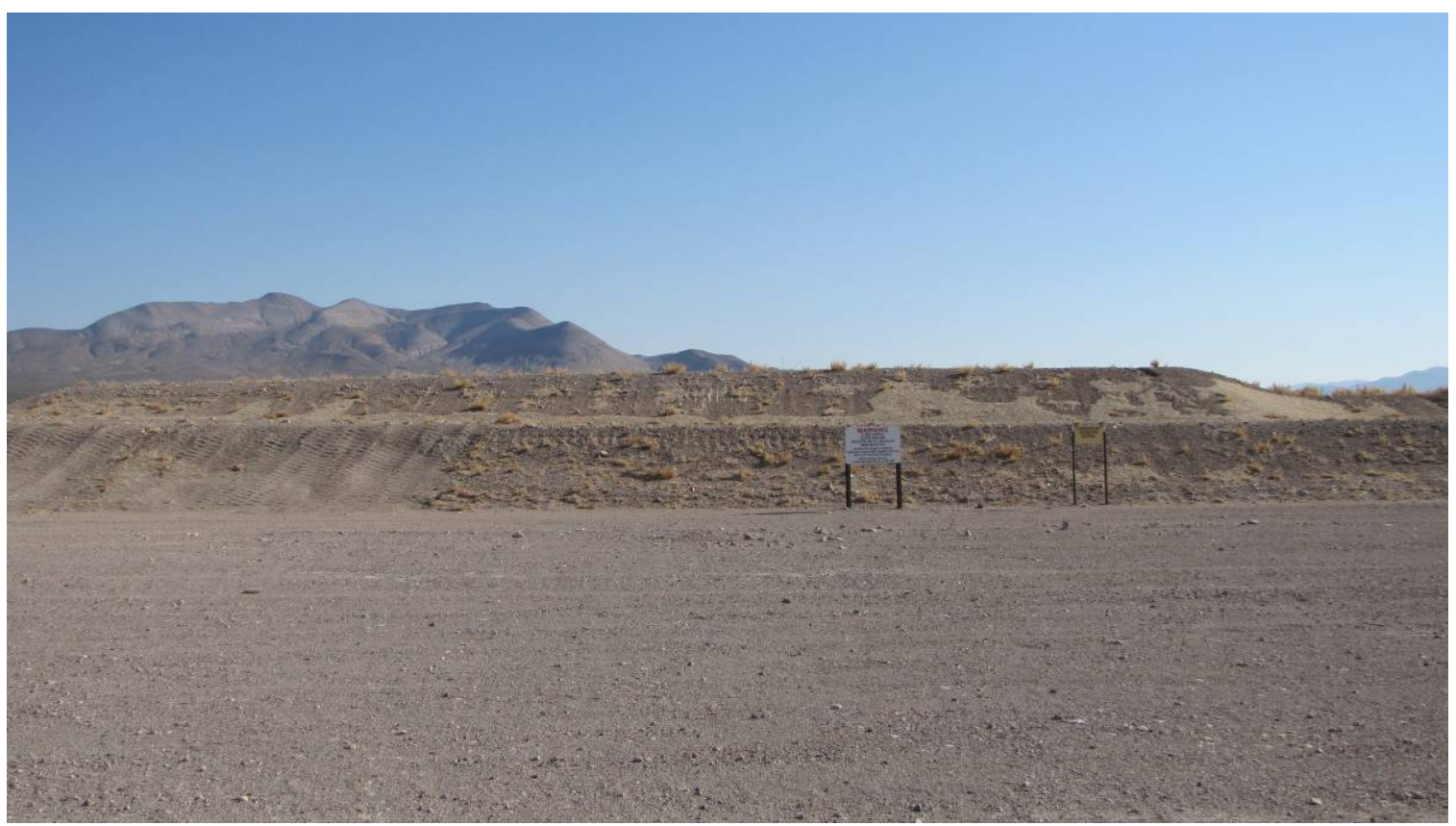

Photograph 113: CAU 111, South Cover Facing North, 06/18/2013

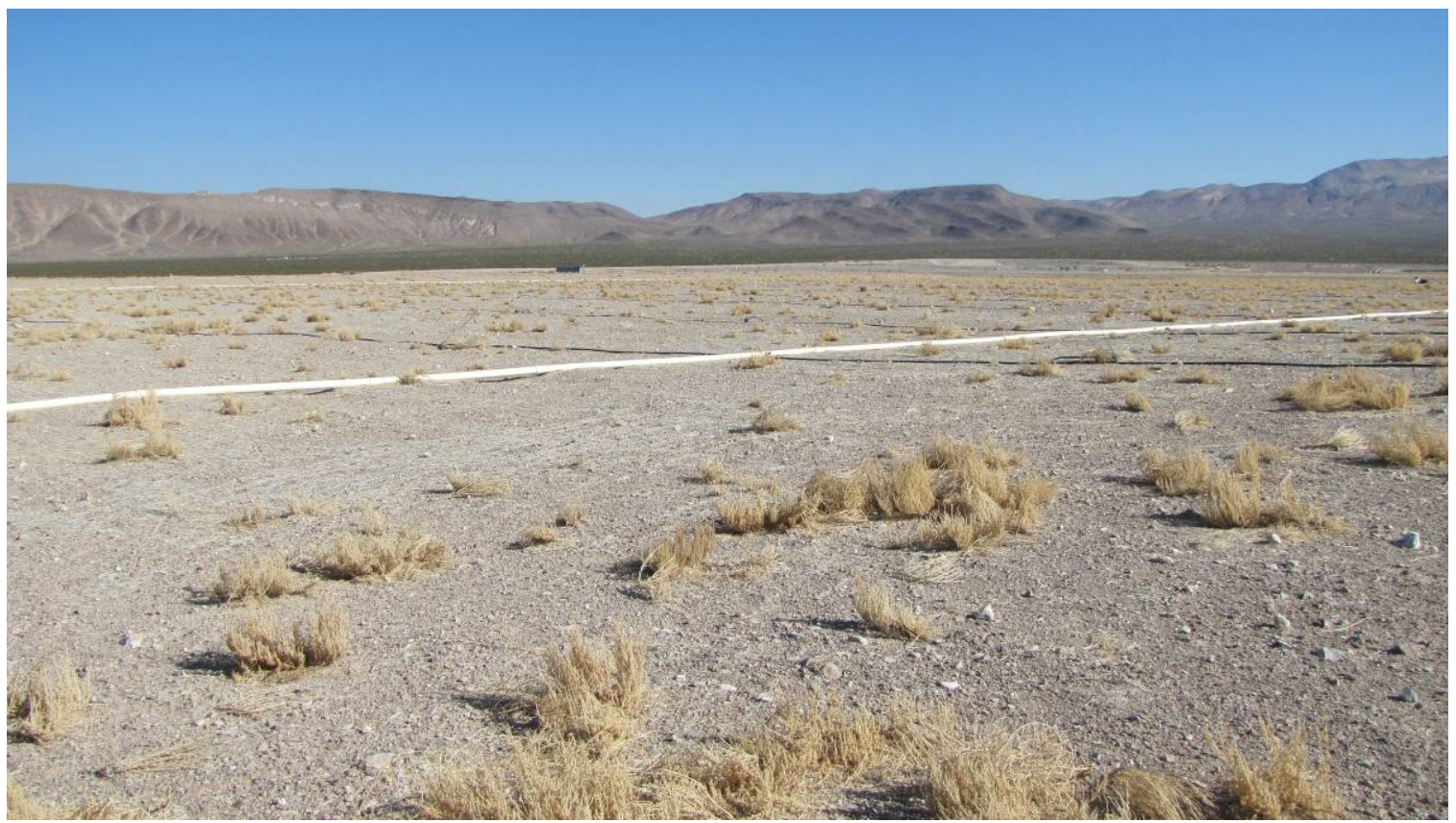

Photograph 114: CAU 111, South Cover Facing Northwest, 06/18/2013 
RCRA Post-Closure Report

Revision: 0

Date: January 2014

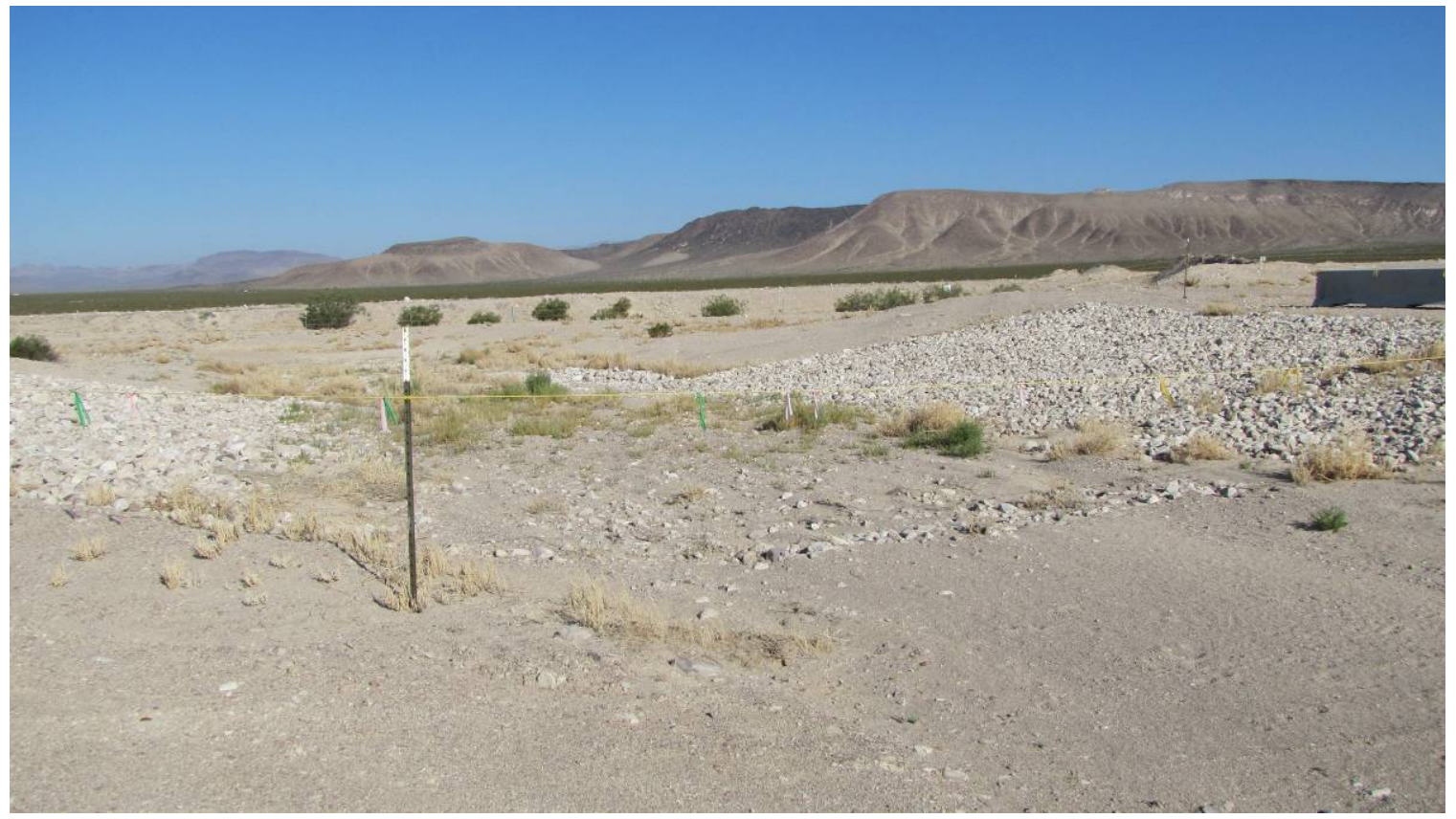

Photograph 115: CAU 111, Arizona Crossing Facing West, 06/18/2013 


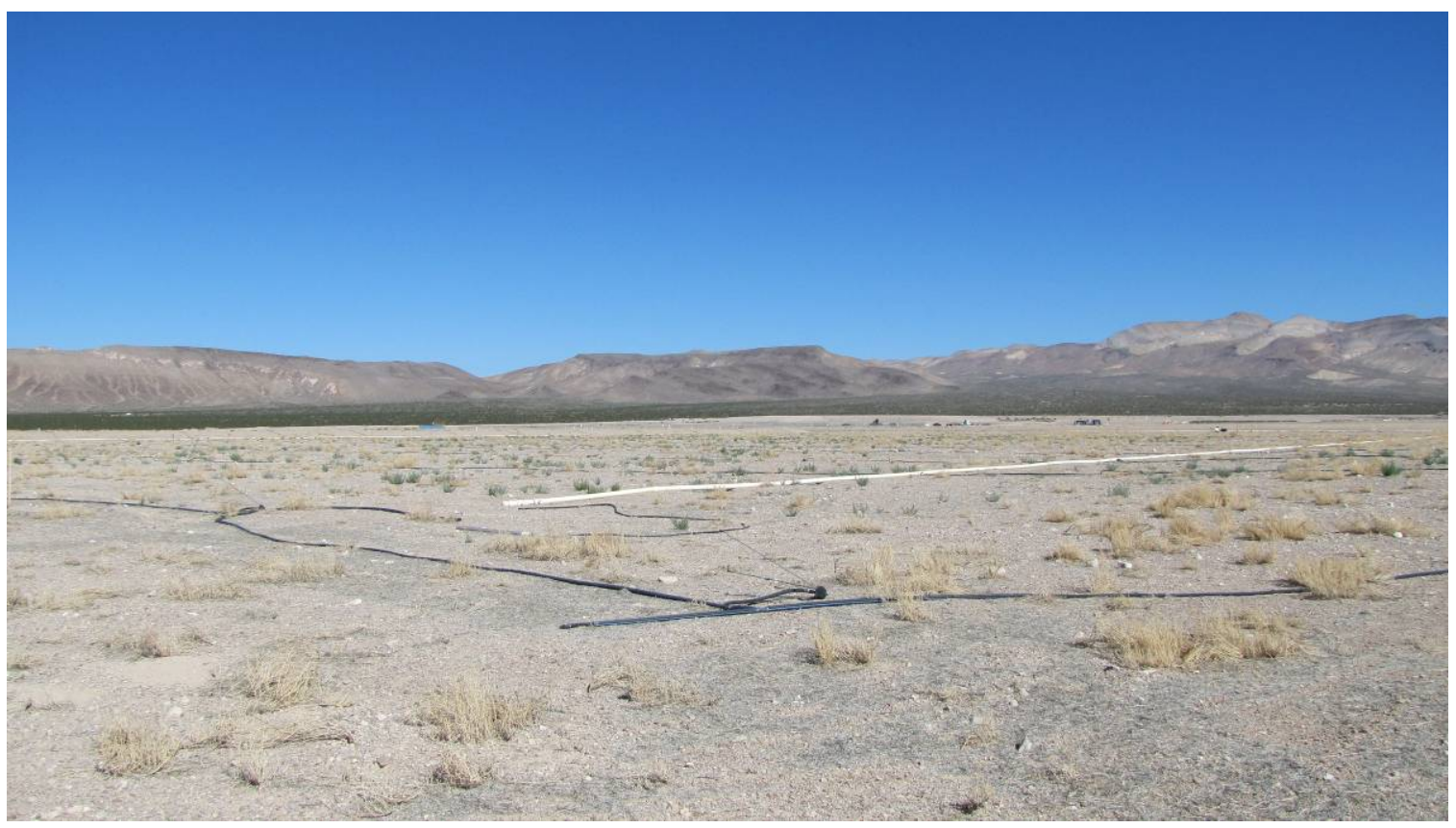

Photograph 116: CAU 111, Lower North Cover Facing North, 09/17/2013

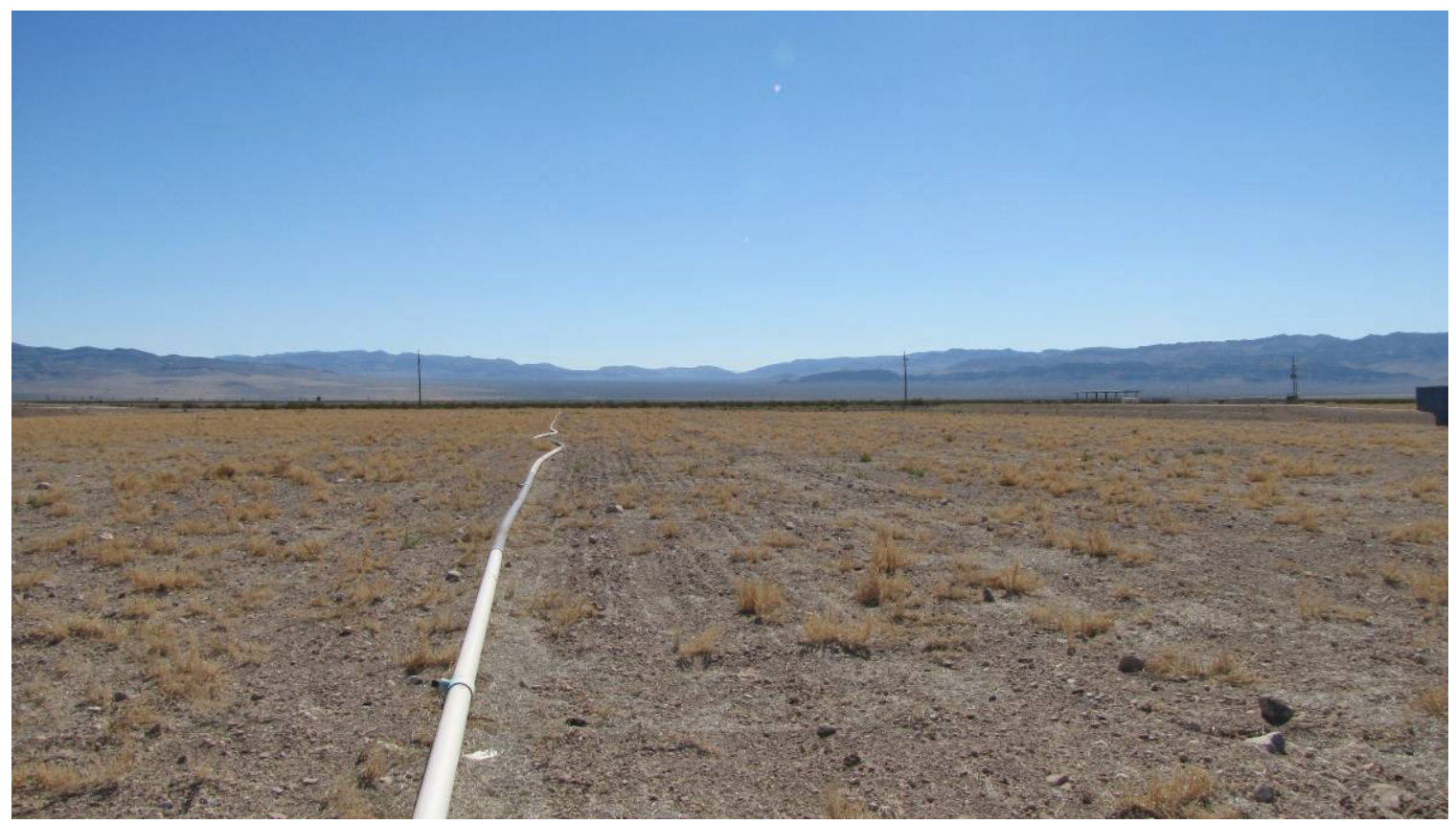

Photograph 117: CAU 111, Lower North Cover Facing East, 09/17/2013 


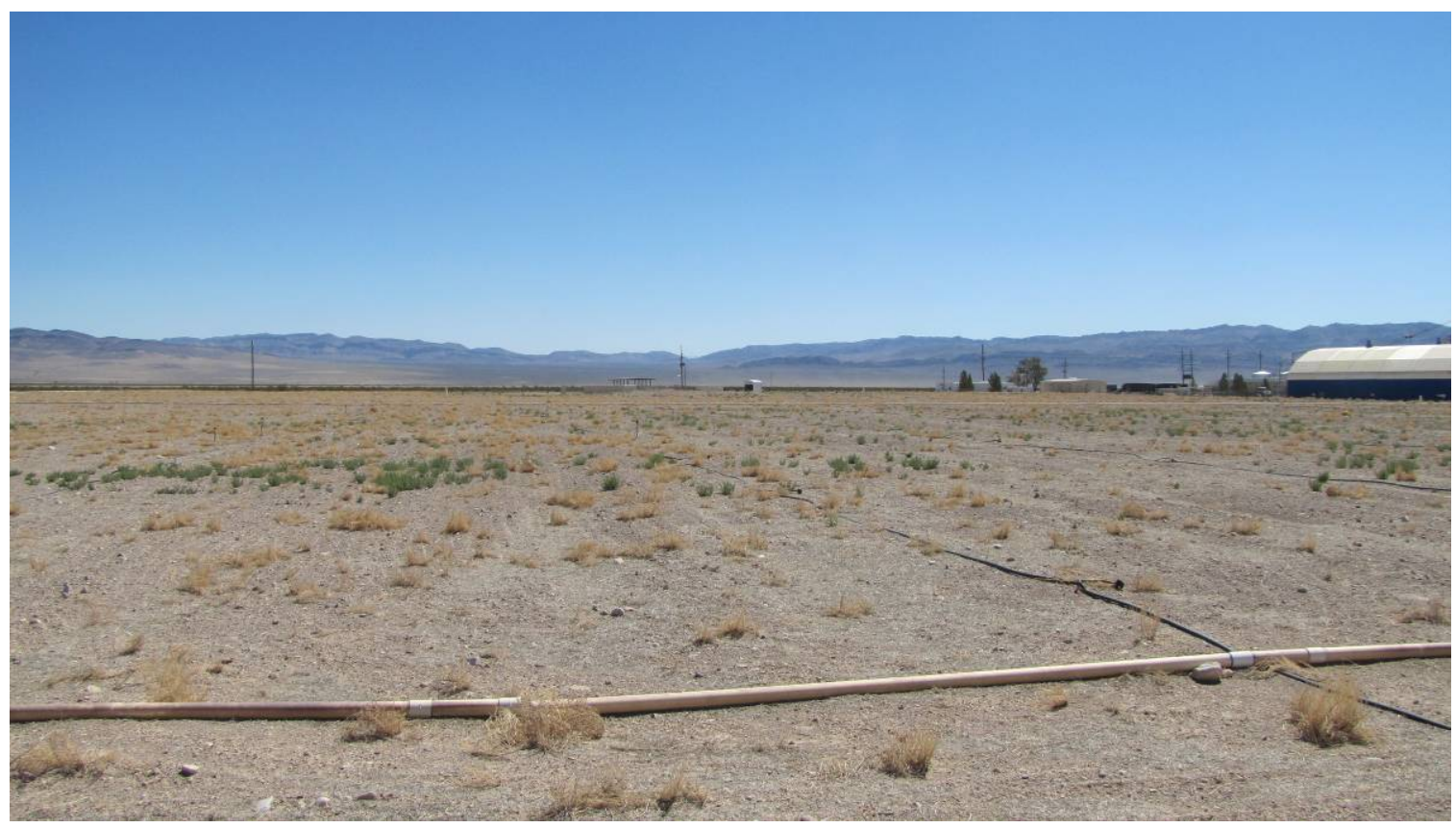

Photograph 118: CAU 111, South Cover Facing East, 09/17/2013

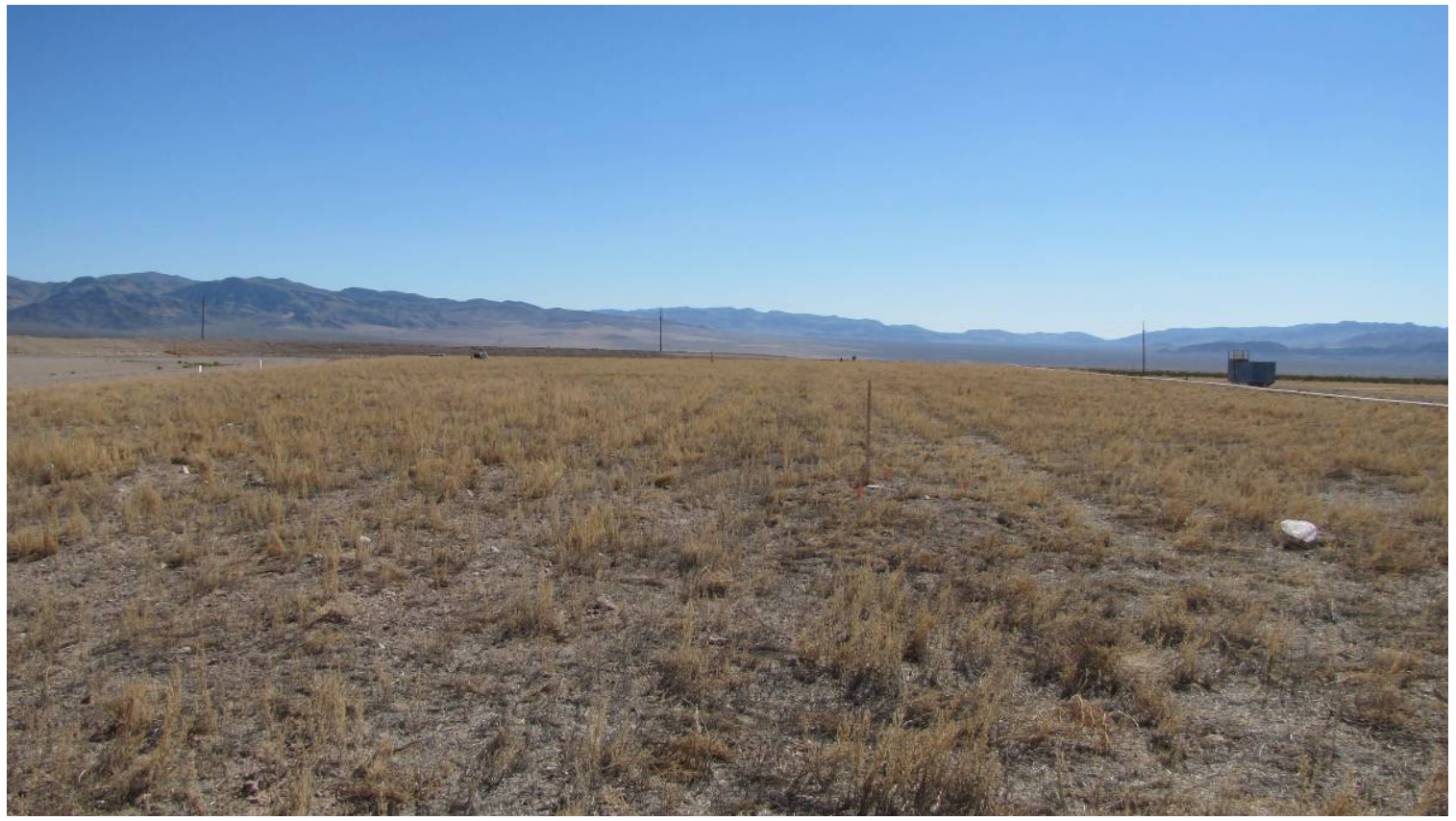

Photograph 119: CAU 111, Upper North Cover Facing East, 09/17/2013 
RCRA Post-Closure Report

Date: January 2014

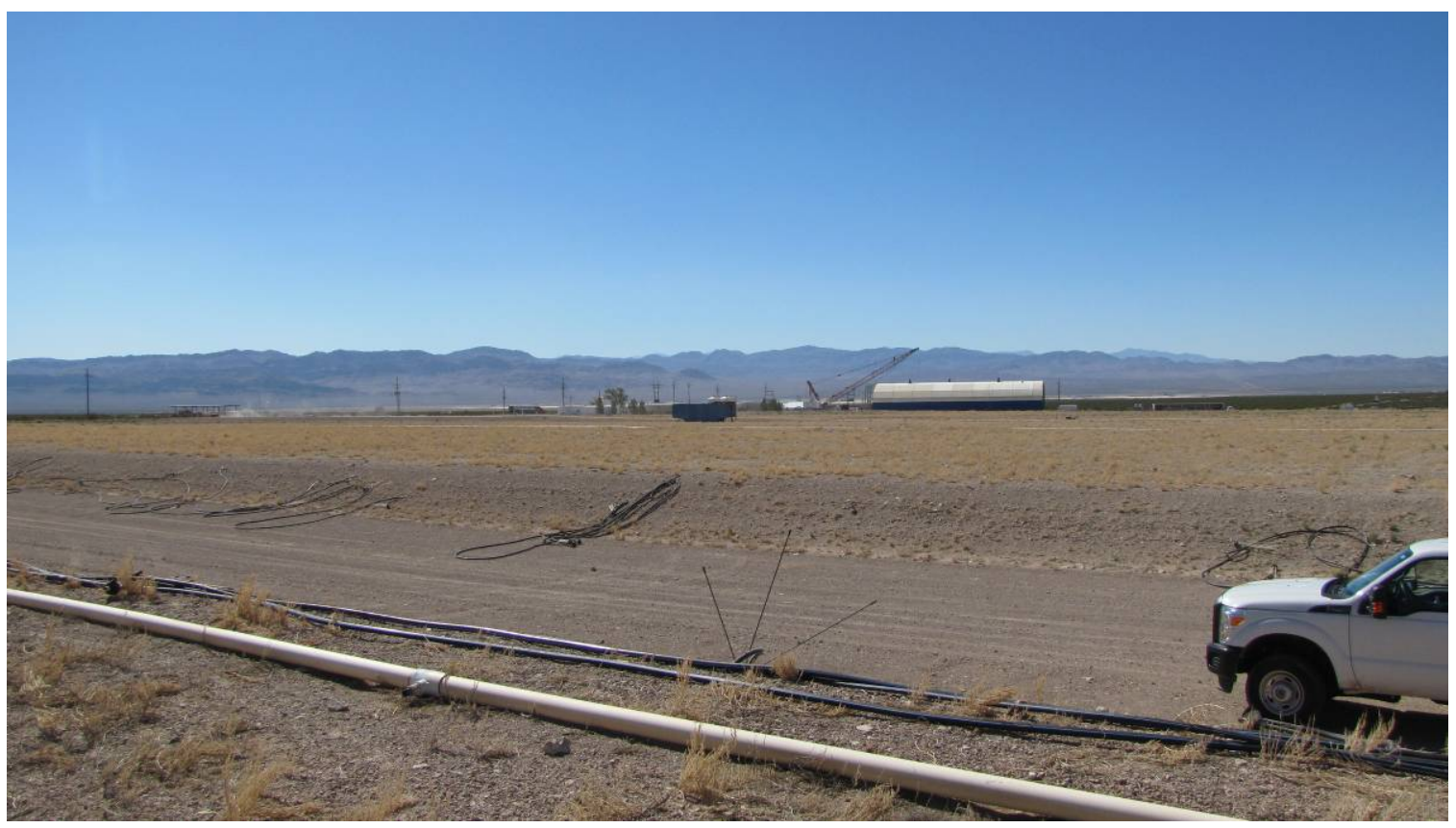

Photograph 120: CAU 111, Upper North Cover Facing South, 09/17/2013

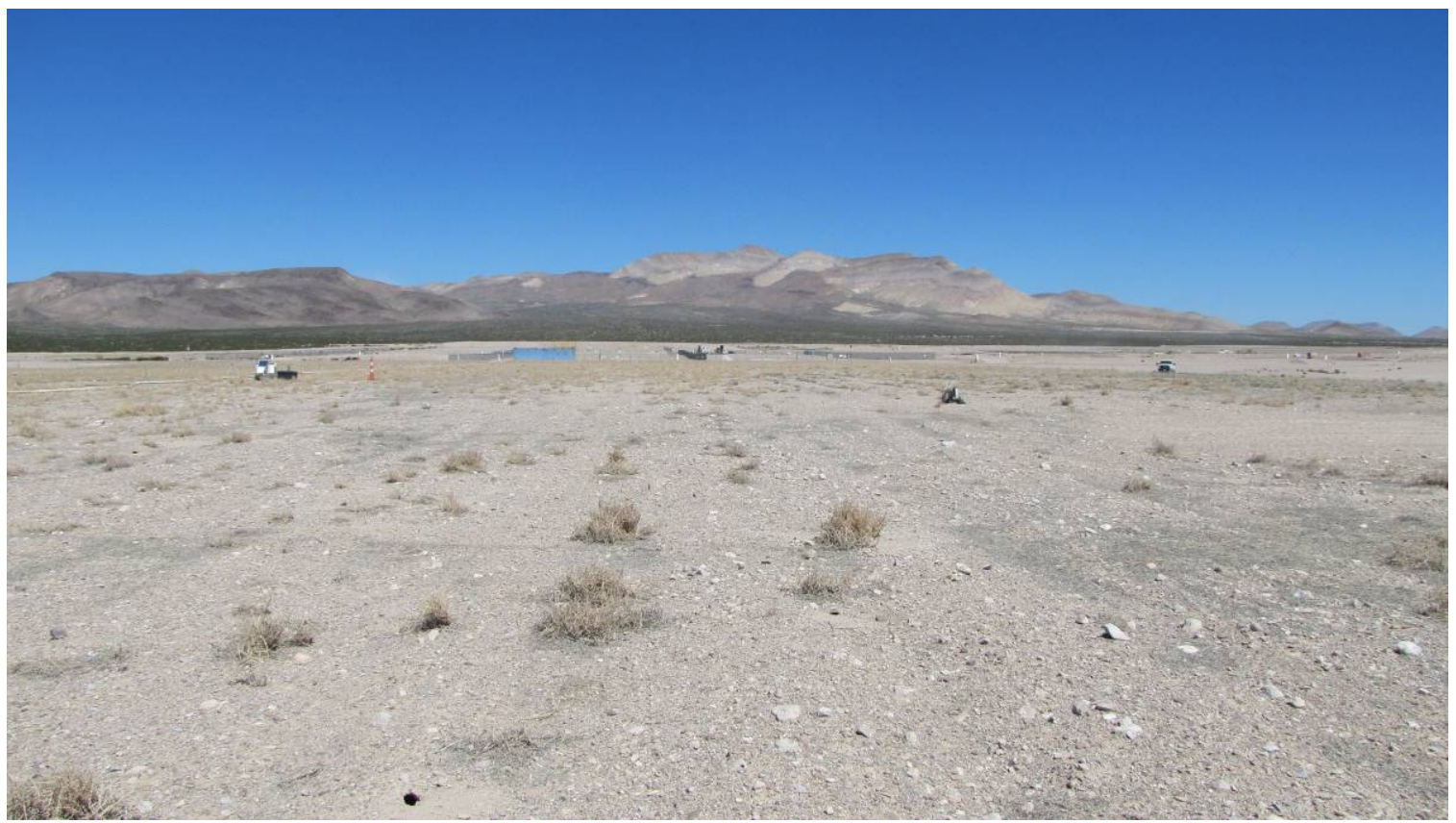

Photograph 121: CAU 111, West Cover Facing North, 09/17/2013 


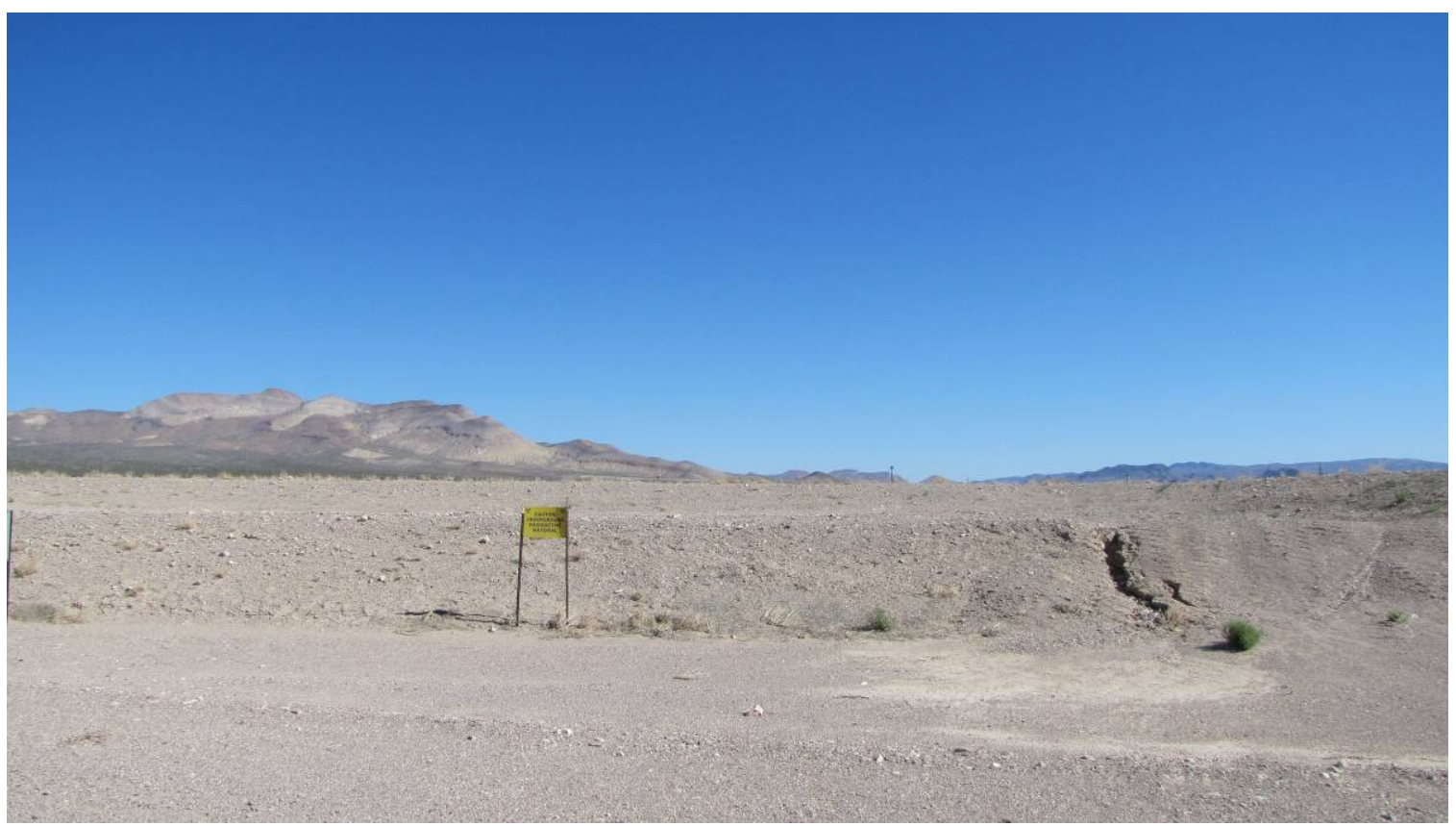

Photograph 122: CAU 111, South Cover Facing North, 9/17/2013

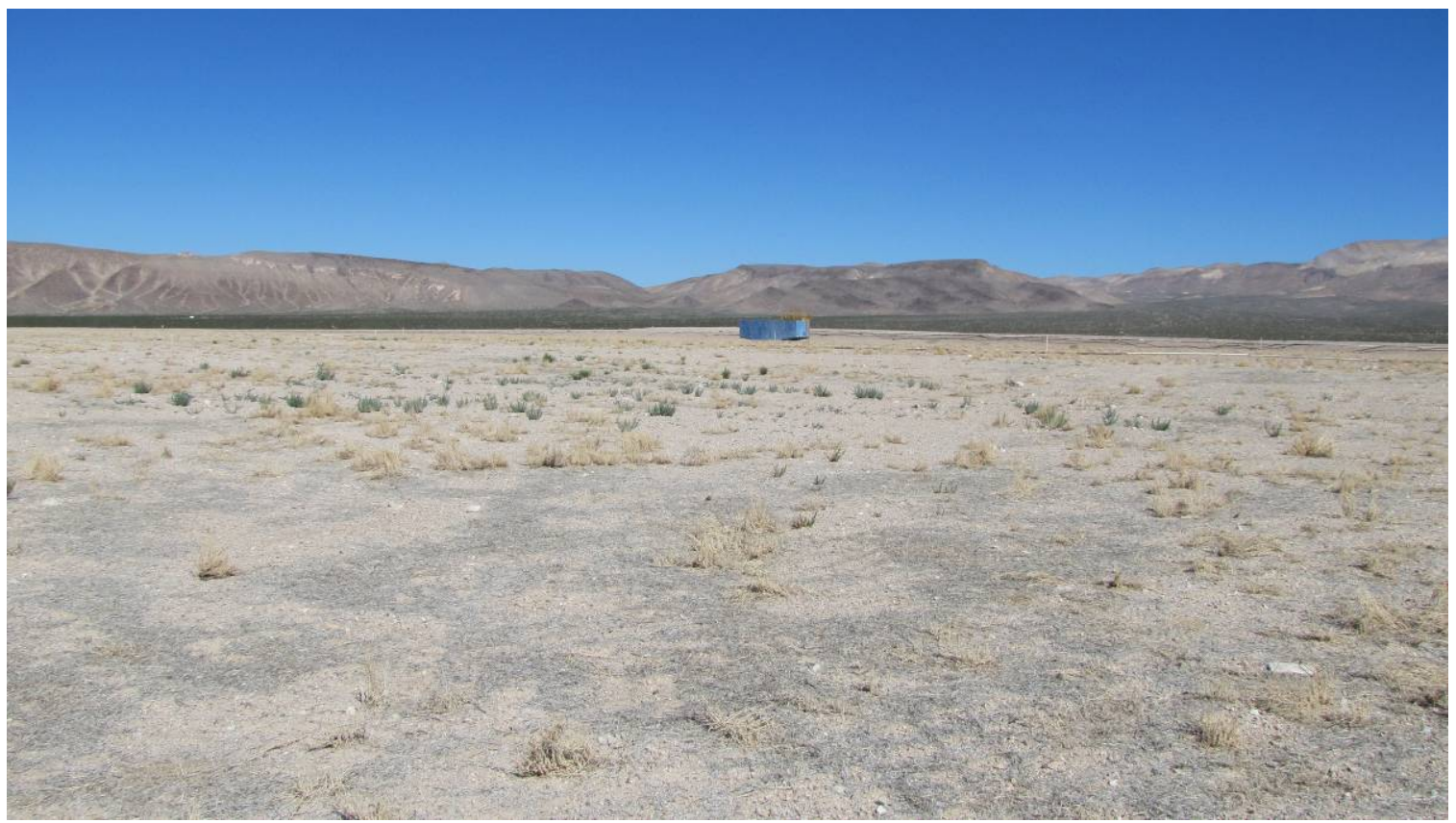

Photograph 123: CAU 111, South Cover Facing Northwest, 09/17/2013 
RCRA Post-Closure Report

Revision: 0

Date: January 2014

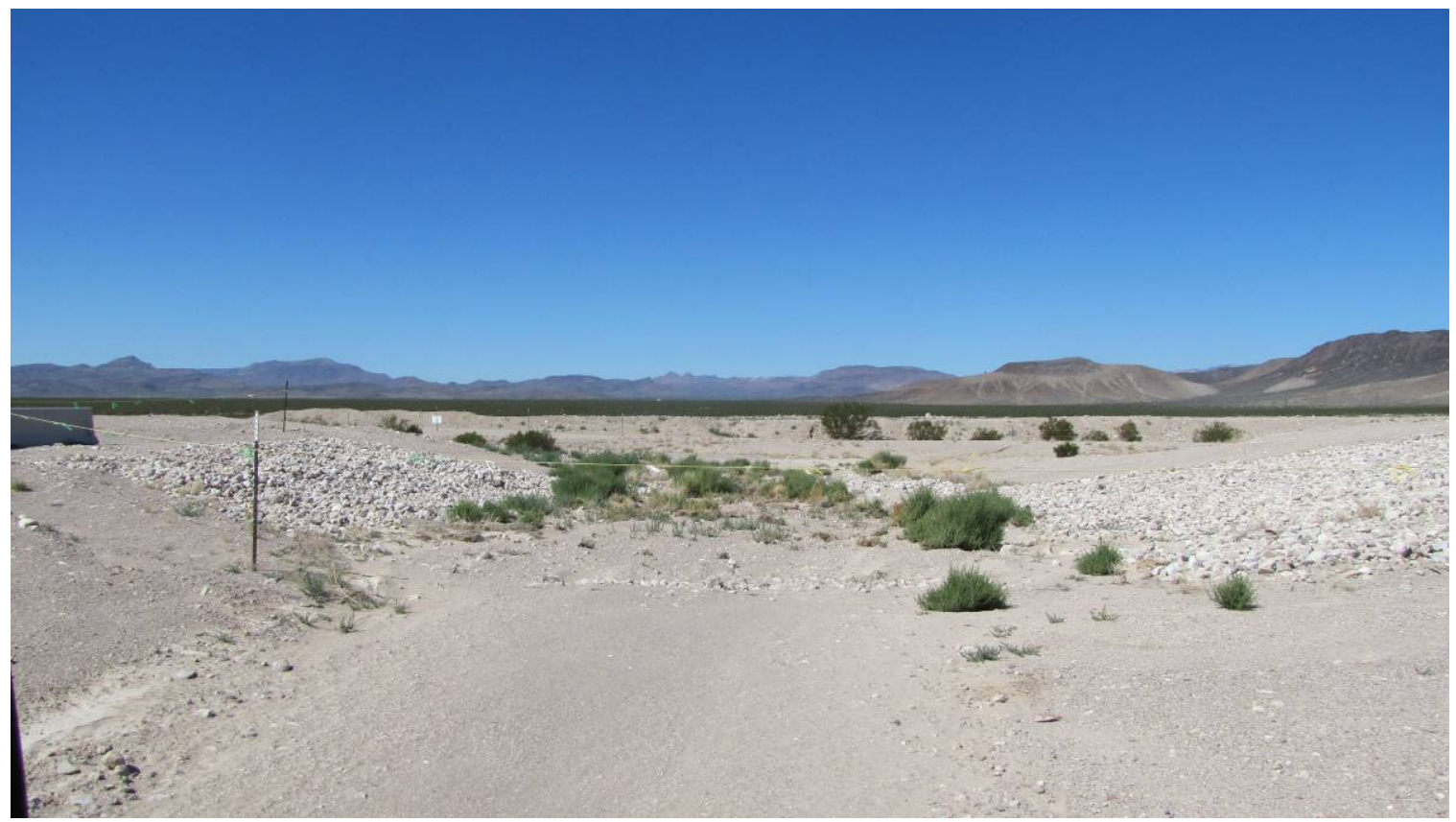

Photograph 124: CAU 111, Arizona Crossing Facing West, 09/17/2013 
RCRA Post-Closure Report

Revision: 0

Date: January 2014

\section{LIBRARY DISTRIBUTION LIST}


RCRA Post-Closure Report

Revision: 0

Date: January 2014

THIS PAGE INTENTIONALLY LEFT BLANK 


\section{LIBRARY DISTRIBUTION LIST}

U.S. Department of Energy

Office of Scientific and Technical Information

P.O. Box 62

Oak Ridge, TN 37831-0062

Southern Nevada Public Reading Facility

c/o Nuclear Testing Archive

P.O. Box 98521, M/S 400

Las Vegas, NV 89193-8521

Manager, Northern Nevada FFACO

Public Reading Facility

c/o Nevada State Library \& Archives

Carson City, NV 89701-4285
1 (Uncontrolled, electronic copy)

2 (Uncontrolled, electronic copies)

1 (Uncontrolled, electronic copy) 
RCRA Post-Closure Report

Revision: 0

Date: January 2014

THIS PAGE INTENTIONALLY LEFT BLANK 